\title{
Assessment of the Dynamic Properties of Soils from Triaxial Tests
}

\author{
By \\ Thavakumaran Shanmugarajah \\ B.Sc (Eng), University of Moratuwa, Sri Lanka (2013)
}

A thesis submitted to the Faculty of Graduate and Postdoctoral Affairs in partial fulfillment of the requirements for the degree of Master of Applied Science in Civil Engineering in

Department of Civil and Environmental Engineering Carleton University

Ottawa-Carleton Institute of Civil and Environmental Engineering Ottawa, Ontario

(C) Thavakumaran Shanmugarajah, 2017 


\begin{abstract}
A detailed laboratory testing programme was conducted on undisturbed sensitive Leda clay samples obtained from Quebec area (Breckenridge and Outardes-2) and on relatively uniform sands (Fraser River sand and Ottawa sand) under triaxial loading mode. Monotonic and cyclic behavior of sensitive Leda clay were studied by performing large strain tests at various consolidation conditions. Small strain stress controlled quasicyclic tests were conducted on both clay and sand to establish site-specific modulus reduction and damping ratio curves at small strain amplitudes

The shear strength and cyclic resistance of Leda clay under triaxial testing mode is noted to be significantly higher than the previously reported values under simple shear loading conditions. Further, it is confirmed that both consolidation stress and over consolidation ratio influence the monotonic shear strength of clay.

Site specific modulus reduction and damping ratio curves are proposed for Leda clay, Fraser River sand and Ottawa sand. The proposed dynamic curves for Leda clay indicate that the behavior of sensitive clays does not follow any particular curve proposed in the literature for non-sensitive clays. These results also suggest that modulus reduction and damping curves are loading path dependent.
\end{abstract}




\section{Acknowledgements}

I would like to devote my sincere gratitude to my research supervisor, Professor Siva Sivathayalan for his continuous guidance, encouragement, understanding and support throughout my years at Carleton University which gave me a lot of comfort to complete my Masters research programme successfully. It has been a great pleasure to work with him.

I have earned the knowledge and experience in the advanced geotechnical laboratory in Carleton university. I greatly acknowledge the technical assistance provided by lab technicians Stanly, Pierre, Jason and all others.

I would like to take this opportunity to thank all my friends for their support encouragement throughout the process. I am especially grateful to Theenathayarl, Sentheepan, Chaitanya and Prasanna for their guidance.

Most importantly, I would like to express my deepest gratitude to my mother, siblings and all my friends for their support, understanding, patience and love throughout my studies and life. 


\section{Table of Contents}

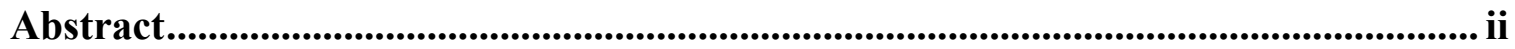

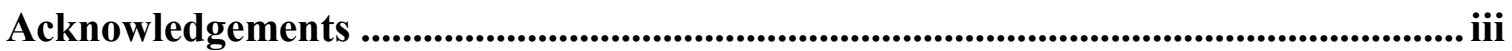

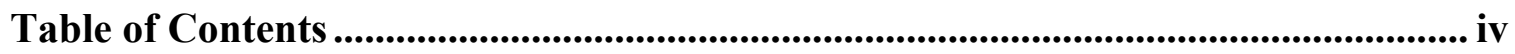

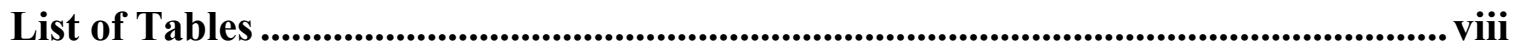

List of Figures......................................................................................................................... ix

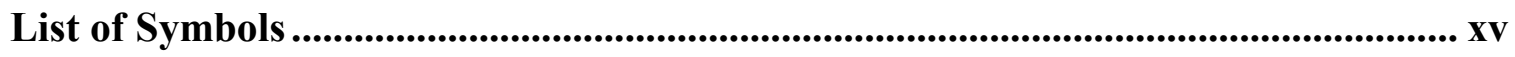

1 Introduction ................................................................................................................................. 1

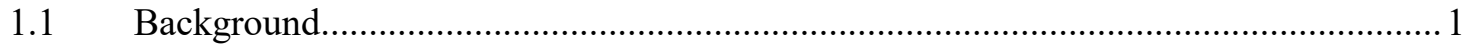

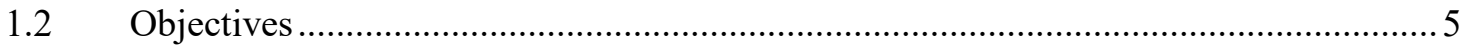

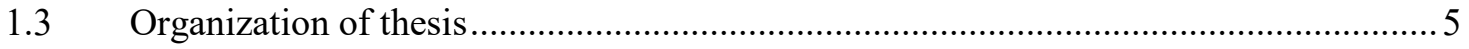

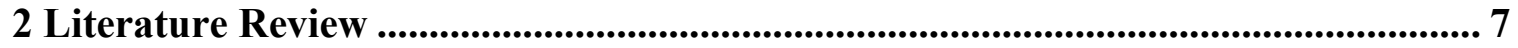

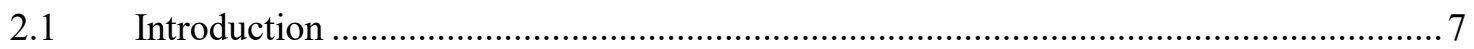

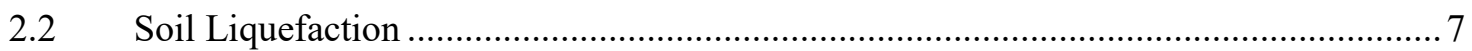

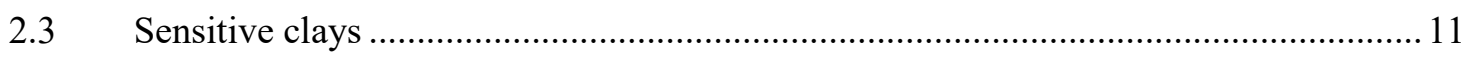

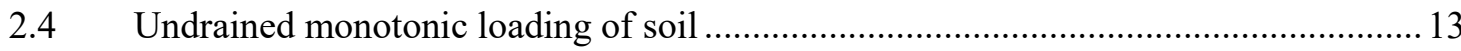

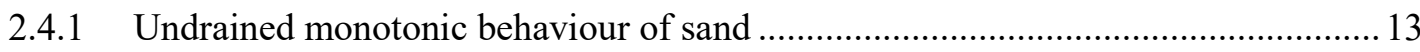

2.4.2 Undrained monotonic behavior of Clay ................................................................. 16

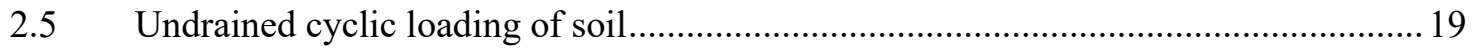

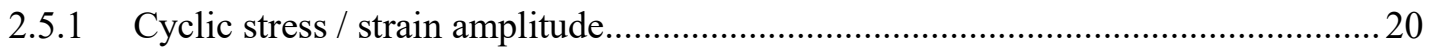

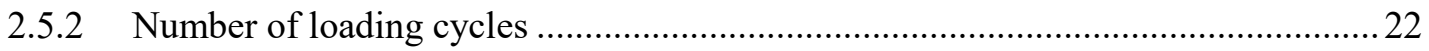

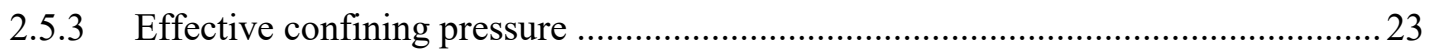

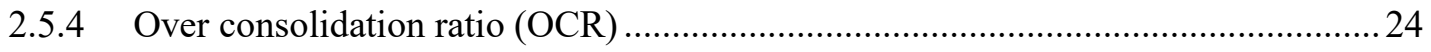

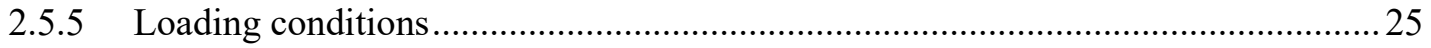

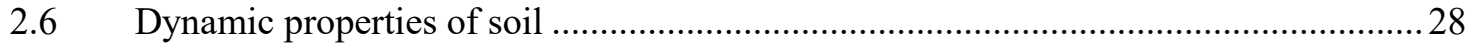




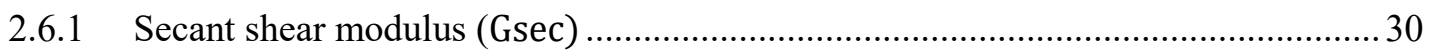

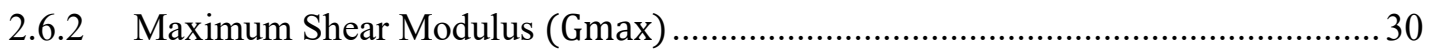

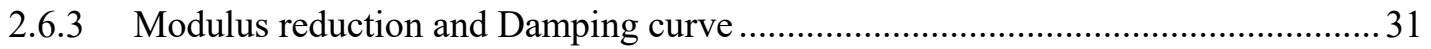

3 Experimental Programme..................................................................................................... 36

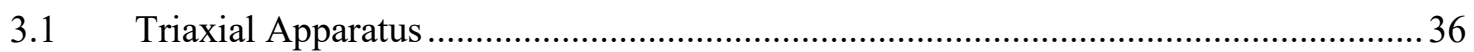

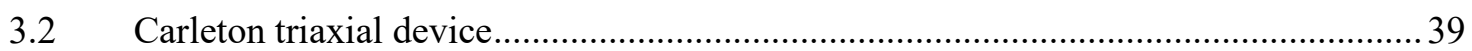

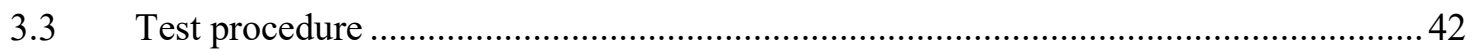

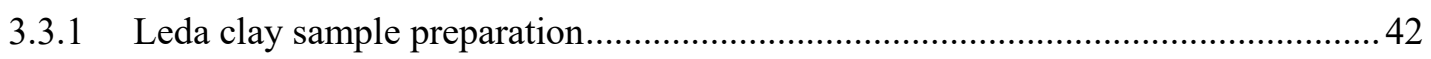

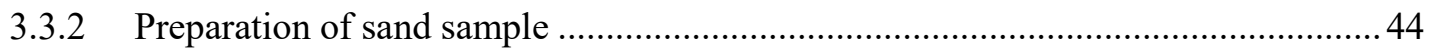

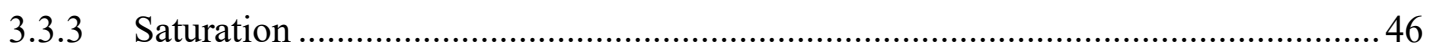

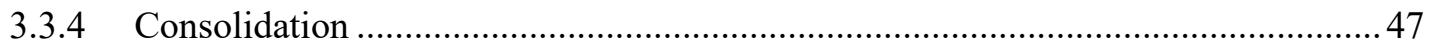

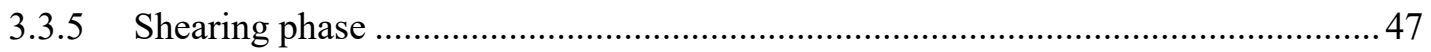

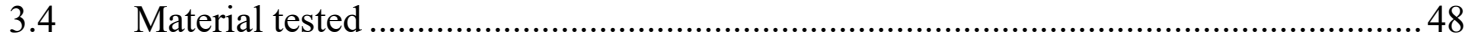

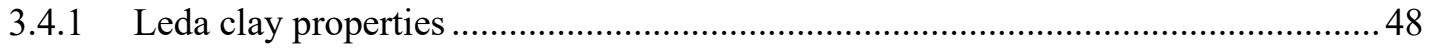

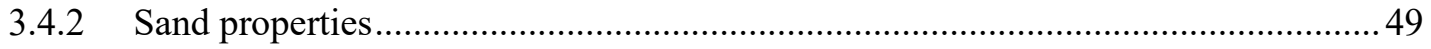

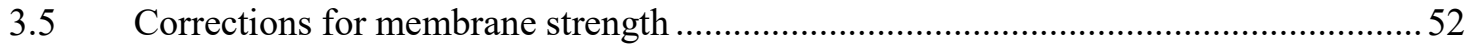

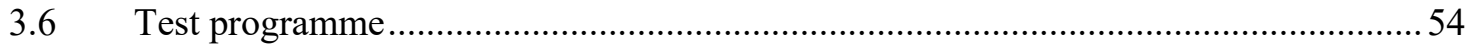

4 Monotonic and Cyclic behavior of Leda clay ............................................................ 57

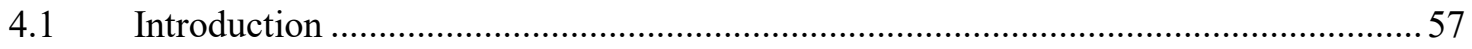

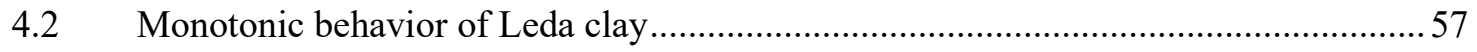

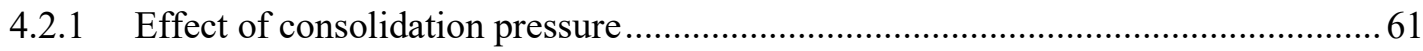

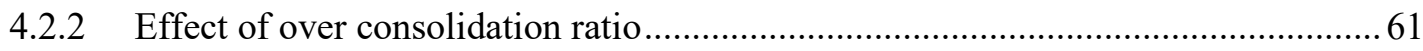

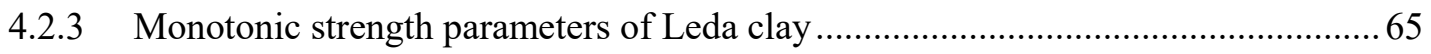

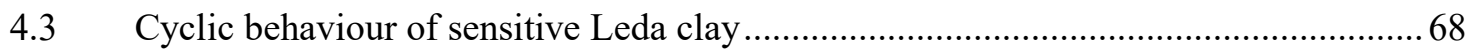

4.3.1 Effect of cyclic stress amplitude and number of cycles ....................................... 75 


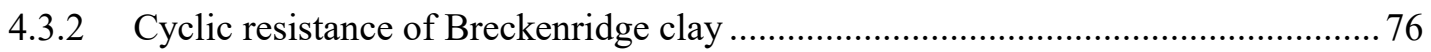

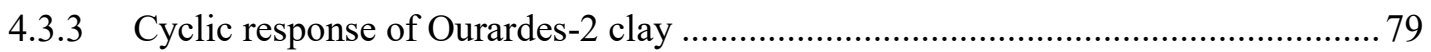

4.3.4 Comparison of cyclic resistance between Triaxial and Simple shear loading

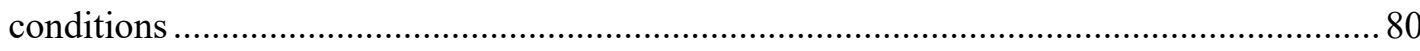

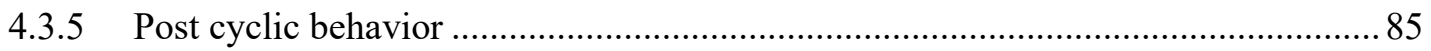

5 Dynamic behavior of Leda clay and sands .............................................................. 89

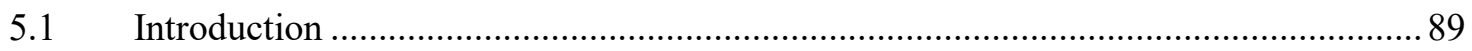

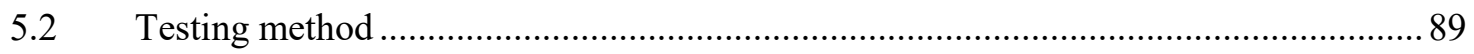

5.3 Modulus and Damping characteristics of Leda clay.............................................. 95

5.3.1 Calculation of the secant shear modulus $\left(\mathrm{G}_{\mathrm{s}}\right)$ and damping ratio $(\xi)$..................... 95

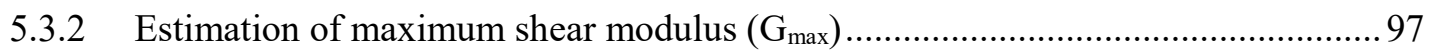

5.4 Modulus and damping of sensitive clays........................................................... 99

5.5 Modulus reduction and damping curves of sensitive Leda clay ............................... 106

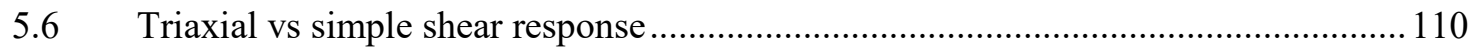

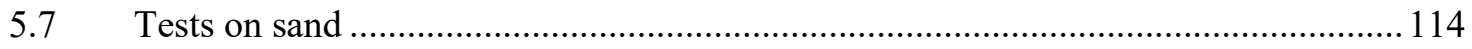

5.7.1 Shear modulus and damping ratio characteristic of sand .................................... 115

5.7.1.1 Calculation of secant shear modulus and damping ratio of sand...................116

5.7.1.2 Secant shear modulus, normalized shear modulus and damping ratio

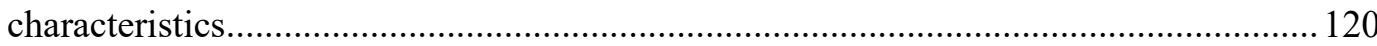

5.7.1.3 Modulus reduction and damping ratio curves of sands ............................... 128

6 Summary and conclusions............................................................................................... 131

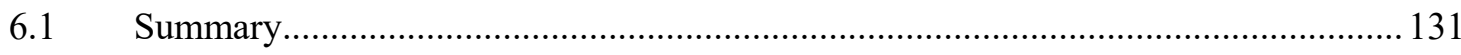

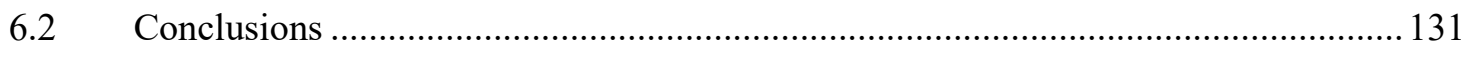

6.2.1 Undrained cyclic and post-cyclic behaviour of Leda clay ................................ 133

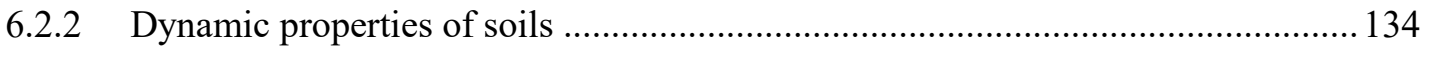


6.2.2.1 Modulus and damping characteristics of sensitive Leda clays

6.2.2.2 Modulus and damping characteristic of sands......

6.2.3 Recommendations for future work.

Bibliography or References................................................................................ 136 


\section{List of Tables}

Table 2-1 Sensitivity classifications in Skempton and Northey (1952) ......................... 12

Table 2-2 Sensitivity Classifications in the CFEM (2006, 4th edition).......................... 13

Table 2-3 Influence of various factors on Maximum shear modulus, Modulus reduction and damping ratio (modified after Vucetic and Dobry, 1987).................... 35

Table 3-1 Primary components of a typical triaxial system and its function................... 37

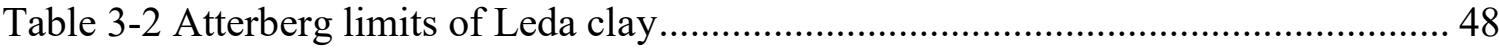

Table 3-3 Material properties of Fraser River sand and Ottawa sand ........................... 50

Table 3-4 Details of monotonic test on Leda clays................................................... 55

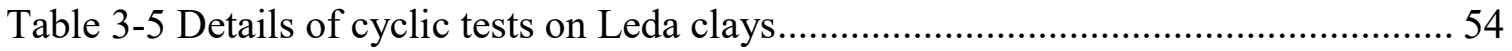

Table 3-6 Details of stress controlled small strain tests on Leda clay ............................ 55

Table 3-7 Details of stress controlled small strain tests on sands ................................. 56

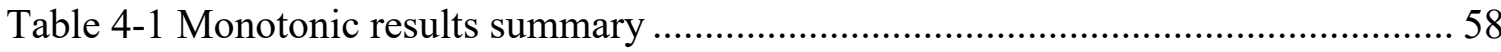

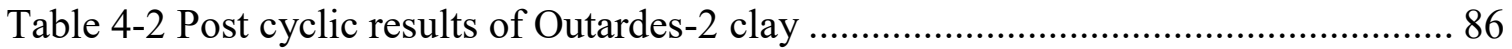




\section{List of Figures}

Figure 1-1 Potential earthquake magnitudes in Ottawa-Quebec region (Natural Resources

Canada) 3

Figure 1-2 Sensitive Leda clay deposit around Ottawa-Quebec area (modified after Quinn et al,2007) 4

Figure 2-1 Recommendations regarding assessment of "Liquefiable" soil types (after

Seed et al, 2003) 10

Figure 2-2 Undrained monotonic response of saturated sands (After Chern, 1985) ........ 14

Figure 2-3 Typical undrained monotonic response of clay (after Ladd \& Foott, 1974)... 17

Figure 2-4 Typical undrained strength variation with consolidation pressure (after Craig, 2004) 17

Figure 2-5 Variation of normalized undrained shear strength with strain rate (after Díaz-

Rodríguez at el., 2009)

Figure 2-6 Stress - Strain and Effective stress path plots of undrained cyclic test of saturated clay (After Zergoun and Vaid 1994)

Figure 2-7 Relationship between earthquake magnitude and number of loading cycles (after Boulanger and Idriss, 2004) 23

Figure 2-8 Influence of effective confining stress on cyclic failure (after Bray and Sancio, 2006) 24

Figure 2-9 Influence of OCR on cyclic resistance of sand (after Ishihara and Takatsu, 1979) 25

Figure 2-10 Variation of $\mathrm{Cr}$ with confining stress in sand (after Vaid ans Sivathayalan, 1996) 26 
Figure 2-11 Different loading conditions along the potential failure surfaces (after

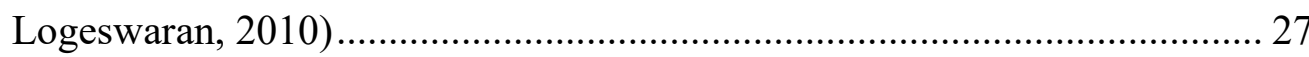

Figure 2-12 Typical hysteresis loop of soil during cyclic loading............................... 28

Figure 2-13 Backbone curve and typical modulus reduction curve of soil (after Kramer, 1996)

Figure 2-14 Typical Modulus reduction and Damping curve of a soil (after Vucetic and

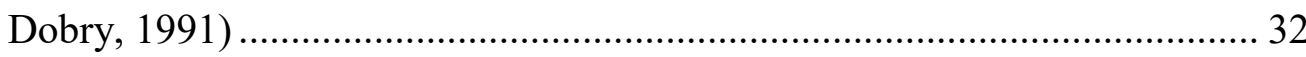

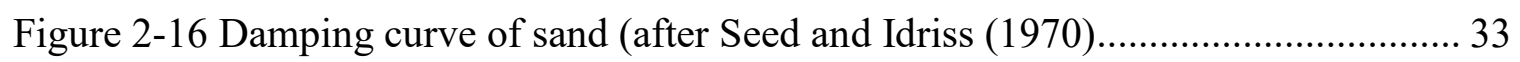

Figure 2-15 Modulus reduction curve of sand (after Seed and Idriss, 1970) .................. 33

Figure 2-17 Modulus reduction curve of clay (after Vucetic and Dobry, 1991) ............. 34

Figure 2-18 Damping curve of clay (after Vucetic and Dobry, 1991)........................... 34

Figure 3-1 Mohr's circle stress representation of (1) isotropically (2) anisotropically consolidated triaxial tests (after Logeswaran, 2010) ................................. 39

Figure 3-2 Schematic diagram of Carleton triaxial device (modified after Logeswaran,

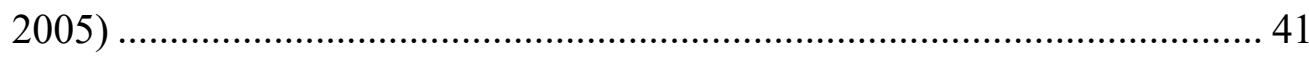

Figure 3-3 Triaxial device at Carleton University ................................................. 42

Figure 3-4 A clay sample in the trimmer before and after trimming ........................... 44

Figure 3-5 Sample in the metal mould, completed trimmed sample and sample after

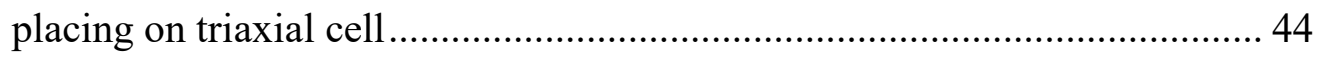

Figure 3-6 Stages of sample preparation using sand ........................................... 46

Figure 3-7 Particle size distribution of Leda clays (modified after Thirugnanasampanther,

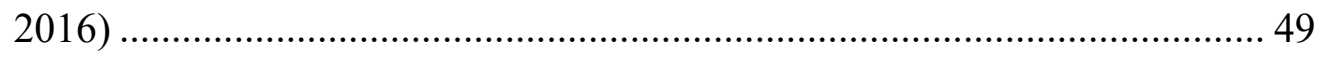

Figure 3-8 Grain size distribution of Fraser River sand (after Logeswaran, 2010) ......... 51 
Figure 3-9 Grain size distribution of Ottawa sand (after Logeswaran, 2005) ................. 52

Figure 3-10 Laboratory setup to determine Young's modulus of membrane.................. 54

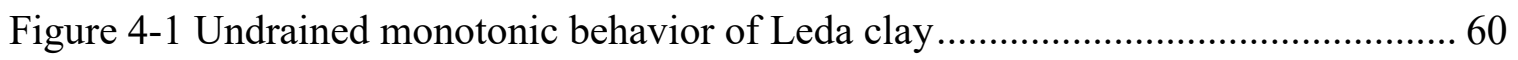

Figure 4-2 Comparison of Monotonic behavior of Leda clay under different consolidation

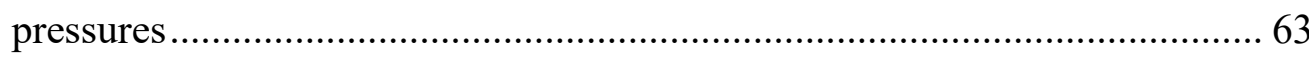

Figure 4-3 Comparison of normalized monotonic behavior of Leda clay...................... 64

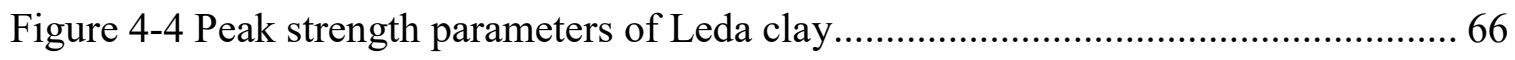

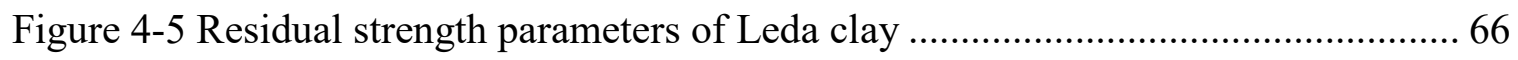

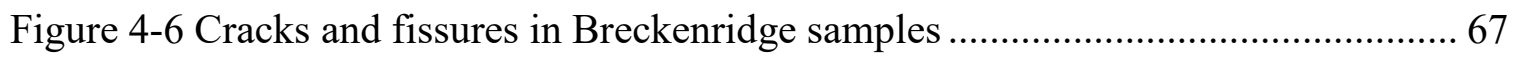

Figure 4-7 Cyclic behavior of Breckenridge clay (deviatoric stress, excess pore water pressure and Axial strain variation with number of loading cycles).............70

Figure 4-8 Cyclic behavior of Breckenridge clay (stress-strain and stress paths) ........... 71

Figure 4-9 Cyclic loading failure mode of Breckenridge sample ................................ 72

Figure 4-10 Cyclic behavior of Outardes-2 (deviatoric stress, excess pore water pressure and Axial strain variation with number of loading cycles) ....................... 73

Figure 4-11 Cyclic behavior of Outardes-2 clay (stress-strain and stress paths)............. 74

Figure 4-12 Very high volumetric strain during the high consolidation pressure ........... 75

Figure 4-13 Deformed shape of the specimen after excess drainage at the end of high

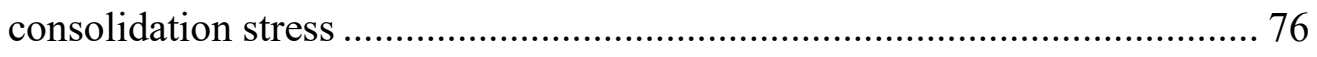

Figure 4-14 Cyclic resistance of Brackenridge samples (CSR vs N) ........................... 77

Figure 4-15 Cyclic resistance of Breckenridge samples (NSR vs N) ......................... 77

Figure 4-16 Monotonic response of Breckenridge and Ouratdes-2 samples .................. 79

Figure 4-17 Cyclic resistance of Outardes-2 samples (CSR vs N) ............................. 80 
Figure 4-18 Simples shear and triaxial results comparison of Brackenridge sample in

CSR form

81

Figure 4-19 Simples shear and triaxial results comparison of Brackenridge sample in

NSR form

Figure 4-20 Simples shear and triaxial results comparison of Outardes-2 sample in CSR

form. 82

Figure 4-21 Simples shear and triaxial results comparison of Outardes-2 sample in NSR

form 82

Figure 4-22 Effect of loading mode on NSR comparison of Outardes-2 clay. 84

Figure 4-23 Comparison of monotonic, cyclic and post-cyclic behavior of Outardes-2

clay 87

Figure 4-24 Normalized post-cyclic behavior Outardes-2 clay 88

Figure 5-1 Single-stage and Multi-Stage Modulus comparison (M\&D-4 and M\&D-3).. 91

Figure 5-2 Typical behavior of Leda clay during quasi-cyclic loading (deviatoric stress, pore pressure and axial strain with $\mathrm{N}$ ) 93

Figure 5-3 Typical behavior of Leda clay during quasi-cyclic loading (Stress-Strain response and stress path) 94

Figure 5-4 Stress-strain loops obtained from stress controlled quasi-cyclic loading

(M\&D-3, Breckenridge sample consolidated at $400 \mathrm{kPa}$ ) 96

Figure 5-5 The measured friction in the system without soil specimen to correct the damping area 97

Figure 5-6 Variation of Maximum shear modulus with effective consolidation pressure 99 
Figure 5-7 (a)-Secant shear modulus, (b)- normalized shear modulus and (c)- damping ratio variation of Breckenridge sample (TO-24-1) with shear strain 101

Figure 5-8 (a)-Secant shear modulus, (b)- normalized shear modulus and (c)- damping ratio variation of Breckenridge sample (TO-24-2) with shear strain 102

Figure 5-9 (a)-Secant shear modulus, (b)- normalized shear modulus and (c)- damping ratio variation of Outardes-2 sample (TM-2C) with shear strain. 103

Figure 5-10 Shear modulus comparison at different OCR values 105

Figure 5-11 Best fit line of modulus reduction and damping of Breckenridge clay....... 107

Figure 5-12 Best fit line of modulus reduction and damping of Outardes-2 clay 108

Figure 5-13 Comparison of Modulus and Damping ratio results of Breckenridge samples under Triaxial and Simple shear loading conditions...... 111

Figure 5-14 Comparison of Modulus and Damping ratio results of Outardes-2 samples under Triaxial and Simple shear loading conditions...... 112

Figure 5-15 Locus of phase transformation of Fraser River sand 115

Figure 5-16 Typical behavior of FRS during stage-drained stress-controlled quasi-cyclic loading........ 118

Figure 5-17 Typical stress-strain loops of FRS 119

Figure 5-18 Dynamic properties of loose FRS at isotopically consolidation 121

Figure 5-19 Dynamic properties of Dense FRS at isotopically consolidation..... 122

Figure 5-20 Dynamic properties of loose Ottawa sand at isotopically consolidation .... 123

Figure 5-21 Dynamic properties of dense Ottawa sand at isotopically consolidation.... 124

Figure 5-22 Dynamic properties of loose FRS at anisotropically consolidation (different mean effective consolidation pressure 125 
Figure 5-23 Dynamic properties of loose FRS at $200 \mathrm{kPa}$ mean effective anisotropically consolidation 126

Figure 5-24 Dynamic properties of dense FRS at $100 \mathrm{kPa}$ mean effective anisotropically consolidation 127

Figure 5-25 The best fit line of modulus reduction and damping ratio of FRS 129

Figure 5-26 The best fit line of modulus reduction and damping ratio of Ottawa sand . 130 


\section{List of Symbols}

$\begin{array}{ll}\text { CSR } & \text { Cyclic stress ratio }\left(\sigma_{c y c} / 2 \sigma_{c}^{\prime}\right) \\ \text { CRR } & \text { Cyclic resistance ratio } \\ C_{r} & \text { The ratio of CSR from simple shear test to triaxial test } \\ \mathrm{NSR} & \text { Normalized stress ratio }\left(\tau_{c y c} / S_{u}\right) \\ \sigma_{c y c} & \text { Cyclic deviatoric stress } \\ \tau_{c y c} & \text { Cyclic shear stress } \\ D_{r} & \text { Relative density } \\ G_{m a x} & \text { Maximum shear modulus } \\ G_{s} \text { or } G_{s} & \text { Secant shear modulus } \\ \mathrm{K}_{\mathrm{c}} & \text { Coefficient of consolidation stress ratio }\left(\sigma_{v c}^{\prime} / \sigma_{h c}^{\prime}\right) \\ \sigma_{v c}^{\prime} & \text { Vertical effective consolidation stress } \\ \sigma_{h c}^{\prime} & \text { Horizontal effective consolidation stress } \\ \mathrm{LVDT} & \text { Linear variable differential transducer } \\ \mathrm{N} & \text { Number of loading cycles } \\ \mathrm{NBCC} & \text { National Building Code of Canada } \\ \mathrm{NC} & \text { Normally consolidated } \\ \text { OC } & \text { Over-consolidated } \\ \text { OCR } & \text { Over-consolidation ratio } \\ \mathrm{PI} & \text { Plasticity index } \\ \mathrm{PL} & \text { Plastic limit } \\ S_{r} & \text { Residual shear stress } \\ S_{t} & \text { Sensitivity } \\ S_{u} & \text { Undrained shear strength } \\ c^{\prime} & \text { Eeriod } \\ e & \text { Void ratio } \\ v_{s} & \text { Depth from ground surface } \\ & \end{array}$




$\begin{array}{ll}\gamma & \text { Shear strain } \\ \gamma_{b} & \text { Bulk unit weight / density } \\ \gamma_{d} & \text { Dry unit weight / density } \\ \gamma_{\max } & \text { Maximum shear strain } \\ \gamma_{t l} & \text { Threshold shear strain for linear behavior } \\ \gamma_{t v} & \text { Threshold shear strain for volume change / pore pressure } \\ \varepsilon_{a} & \text { Axial strain } \\ \varepsilon_{v} & \text { Volumetric strain } \\ \xi & \text { Damping ratio } \\ \rho & \text { Density } \\ \sigma_{1} \& \sigma_{1}^{\prime} & \text { Major principal \& Effective major principal stress } \\ \sigma_{2} \& \sigma_{2}^{\prime} & \text { Intermediate principal \& Effective intermediate principal stress } \\ \sigma_{3} \& \sigma_{3}^{\prime} & \text { Minor principal \& Effective minor principal stress } \\ \sigma_{m}^{\prime}{ }_{m} & \text { Effective mean confining stress } \\ \sigma_{v}^{\prime} & \text { Vertical effective stress } \\ \sigma_{p}^{\prime} & \text { Pre-consolidation stress } \\ \phi^{\prime} & \text { Effective internal angle of friction } \\ \phi_{p T}^{\prime} & \text { Effective internal angle of friction at phase transformation state }\end{array}$




\section{Introduction}

\subsection{Background}

Catastrophic earthquakes during the past two decades (e.g., Northridge 1994, Kansai 1995, Bhuj 2001, Bam 2003, Sumatra 2004, Kashmir 2005, Sichuan 2008, Haiti 2010, Honshu/Fukushima 2011) have destroyed property worth billions of dollars and cost hundreds of thousands of lives. Mohanty and Walling (2007) assert that earthquakes are the biggest cause of disasters in the world, and that they contribute to about $51 \%$ of the total disasters in 20th century. Earthquakes also trigger landslides, lateral spreading, and tsunami waves. Additionally, it can be observed that the collapse of structures can be as a result of super structure, substructure, or complete failure. Therefore, there is a need to understand the type of failure that could have caused a structure to collapse during an earthquake. With such knowledge, it would be possible to devise ways of avoiding such collapse in future.

Alternatively, the ground on which the structure is set can also contribute to the collapse of the building, even when the structure's design is appropriate. The type of soil on which structures are established can play a significant role in determining the stability of structures erected on that soil during earthquakes. If the type of soil on which a building rests is weak, there are high chances that the structure on which it is erected will collapse during calamities such as tremors. Therefore, it is important for geotechnical engineers to have an advanced understanding of the soil type and its characteristics before embarking on plans to erect a structure. That knowledge would be instrumental in guiding the designers on the measures to take to ensure that the soil would not lead to the collapse of structures which are to be erected on such soils. 
Sensitive clays and loose sands prove to be volatile during seismic loading. Construction on such soil requires a better understanding of their earthquake performance to minimize the risks of failure. The structure of sensitive clay may be affected during disturbances such as those caused by earth tremors and earthquakes, and it can lead to significant reduction in shear strength. Development of excess pore water pressure is the cause for concern in loose sands.

There are several regions, such as Canada, Sweden, Norway, and Alaska in the USA, that have sensitive clay deposits. In Eastern Canada, regions of Ontario and Quebec along the St. Lawrence and Ottawa River valleys have a substantial amount of sensitive clay (Figure 1.2). This type of clay has been named "Champlain Sea Clay" or "Leda Clay." Examples of extensive damages associated with the weak characteristic nature and composition of Leda clay include those caused by the Saint-Jean-Vianney landslide in Quebec and the Lemieux earthquake in Ontario, both of which occurred in 1971, and the Lemieux landslide in Ontario that took place in 1993. Additionally, the damages caused by the Saguenay earthquake in Quebec that took place in 1988 were also associated with the poor nature of the Leda clay.

Interestingly, it does not mean that regions that can be categorized as 'stable' in terms of earthquake vulnerability cannot be affected by tremors. For example, eastern Canada can be regarded as a stable region within North American's tectonic plate. However, this region has experienced major earthquakes in the recent past and it is highly likely that others will occur in the future. Examples of earthquakes to have occurred in the eastern region of Canada include the Saguenay earthquake in Quebec that occurred in 1998 which had a magnitude of 6 in the Richter scale, and the Val de-Bois earthquake in 
2010 the epicenter of which was only about $50 \mathrm{~km}$ from Ottawa. This is an indication that the region is prone to experiencing earthquakes of higher magnitudes. Furthermore, the Insurance Bureau of Canada (2013) asserts that an earthquake of a magnitude exceeding 7 on the Richter scale is expected to hit Ottawa and Quebec in the future. Figure 1.1 below represents the magnitudes of potential earthquakes in this region.

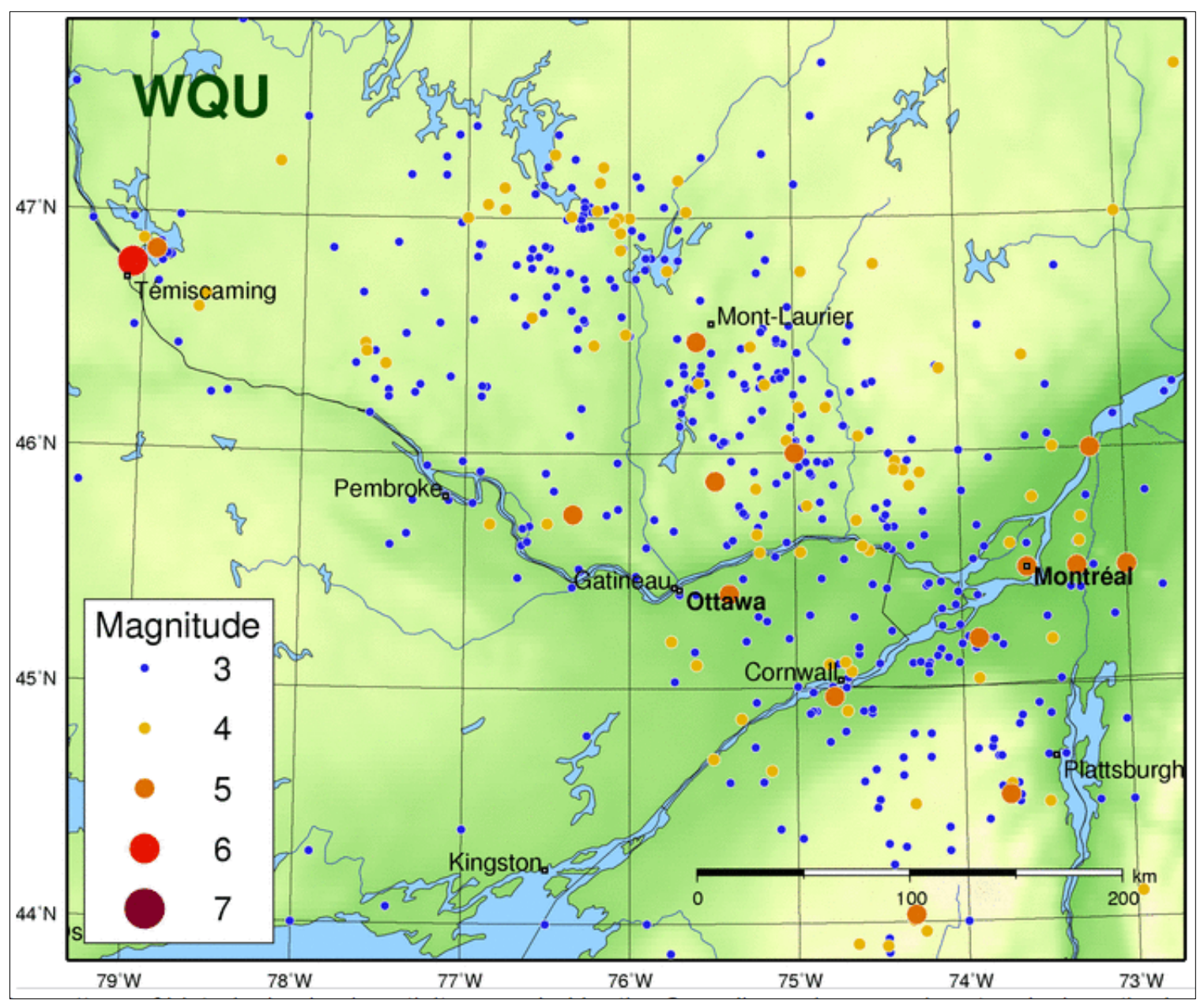

Figure 1-1 Potential earthquake magnitudes in Ottawa-Quebec region (Natural Resources Canada)

Due to the presence of sensitive Leda clay and the vulnerability of the region to earthquakes, geotechnical engineers and researchers are highly concerned about infrastructural design against earthquake loading. Accurate modulus reduction and 
damping ratio are the key input parameters in a seismic ground response analysis. Reliable Leda clay specific modulus reduction and damping curves are essentially nonexistent, and designers commonly use the modulus reduction and damping ratio curves provided for normal clays in the literature for the analysis of sensitive clay. Several researchers have taken time to study the behavior of Leda clay due to its sensitivity, and they include Mitchell and King (1976); Silvestri et al (1989); Theenathayarl (2015); and Thirugnanasampanther, (2016). Recently, Theenathayarl (2015) and Thirugnanasampanther (2016) asserted that dynamic properties of sensitive Leda clay do not follow any particular published curves in the literature. Therefore, it is important to have site-specific modulus reduction and damping curves for a reliable seismic design in sensitive Leda clay regions.

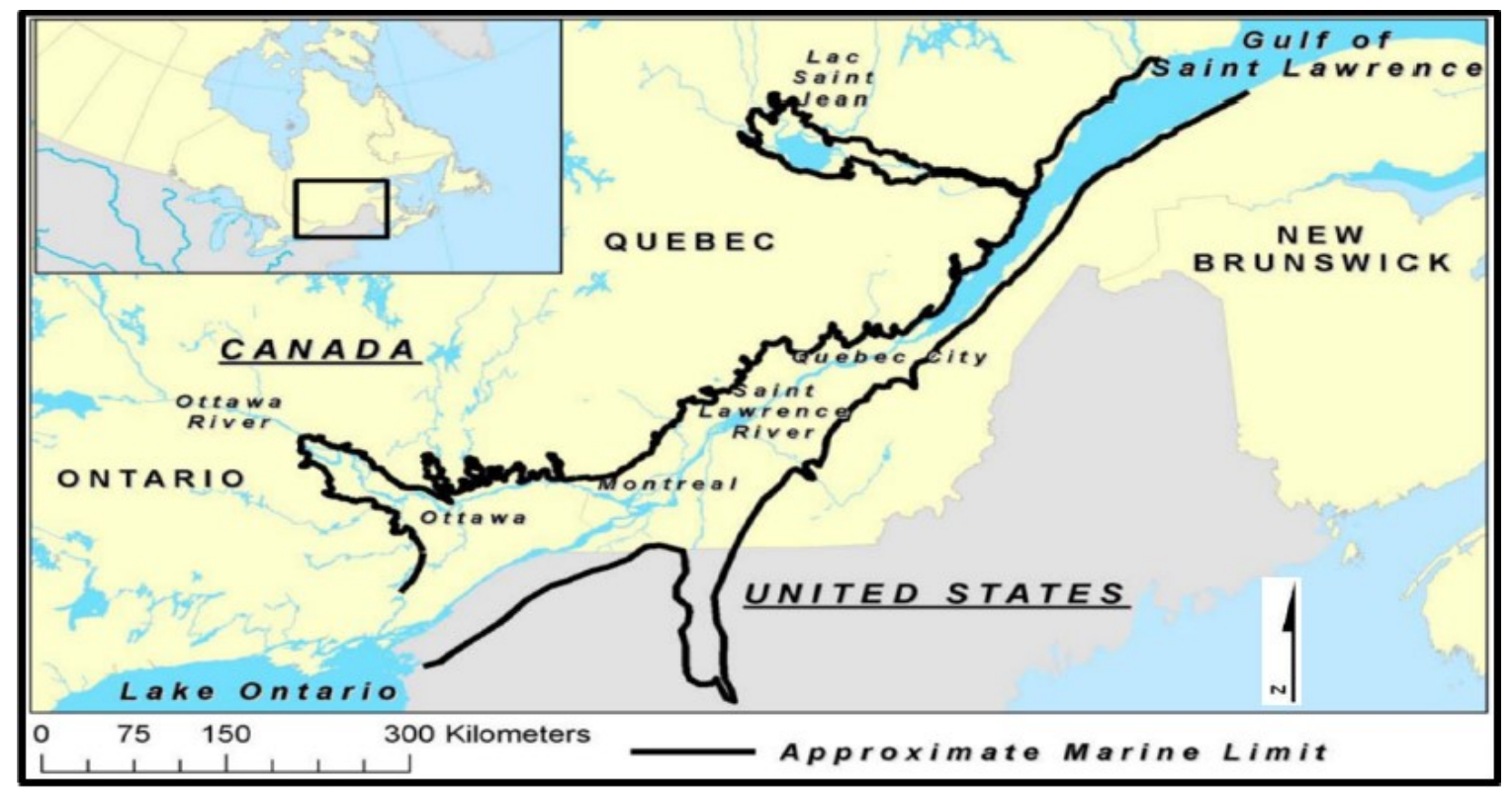

Figure 1-2 Sensitive Leda clay deposit around Ottawa-Quebec area (modified after Quinn et al,2007) 


\subsection{Objectives}

The primary objective of this study is to establish site-specific modulus reduction and damping ratio curves for sensitive Leda clay samples obtained from Breckenridge, in Gatineau, and Outardes-2 in Saguenay in Quebec, under triaxial loading conditions. It will also be important to discuss monotonic, cyclic and post cyclic behavior of sensitive Leda clay under triaxial loading conditions. The experimental study will also evaluate the dependency of undrained monotonic, cyclic and modulus reduction and damping ratio characteristics on parameters such as consolidation pressure, plasticity index and over consolidation ratio. Additionally, the effect of loading path will be studied by comparing these triaxial test results with the published simple shear test results for the same material. Moreover, secant shear modulus, normalized shear modulus and damping ratio characteristic of Fraser River sand and Ottawa sand will be evaluated at different consolidation pressures and different densities. The effect of consolidation stress ratio $\left(\mathrm{K}_{\mathrm{c}}\right)$ on secant shear modulus of Fraser River sand will also be studied in this experimental programme. To achieve these research objectives, modifications will be made to the existing triaxial device at Carleton University, and it will be enhanced to precisely measure very small level of strain and stress confidently.

\subsection{Organization of thesis}

A detailed background study and the current state of the art related to the objectives of this research programme are presented in chapter 2. Soil liquefaction characteristics, undrained monotonic and cyclic behavior of soil are also discussed. Furthermore, the importance of site-specific modulus reduction and damping properties 
of sensitive clay for a reliable ground response analysis is reviewed.

Chapter 3 covers the experimental programme carried out in this research study. It also discusses the triaxial testing device, its capabilities and the enhancements to improve its performance. Further, sample preparation methods, test procedure and properties of tested materials are also presented in this chapter.

Chapter 4 discusses the monotonic and cyclic test results of sensitive Leda clay in addition to the factors influencing the undrained monotonic and cyclic strength of Leda clay at different consolidation pressure.

Chapter 5 discusses the modulus reduction and damping characteristic of Leda clay, Fraser River sand and Ottawa sand. A critical comparison between the obtained results from this study with reported simple shear results for the similar material at similar conditions is included. Finally, Chapter 6 entails the conclusions obtained from this research study and recommendations for future work. 


\section{Literature Review}

\section{$2.1 \quad$ Introduction}

Undrained loading condition can be critical in soils because the gradual generation of pore water pressure during such loading tends to reduce the strength of soils significantly. During earthquakes, there is no space to dissipate the generated pore water pressure (since large regions are subjected to cyclic shaking). In such a scenario, the soil may lose its strength partially or completely regardless of the permeability. This critical behavior is commonly referred to as 'liquefaction' of soil.

A significant amount of study has been conducted in the past few decades to understand the undrained behavior of soils. This chapter provides a comprehensive review of the undrained static and cyclic behavior of sands and sensitive clays.

\subsection{Soil Liquefaction}

The concept of soil liquefaction is built upon the observation that the progressive generation of pore water pressure in soil gradually lessens the contact forces holding the soil particles together. As the effective stresses decrease the soil may, in an extreme scenario, completely lose its load carrying capacity and behave like a liquid, thereby causing severe damage to the structures built upon or within it.

The term "liquefaction" was originally introduced to refer to an excessive deformation of the soil, induced by monotonic or cyclic loading. Incidents of soil liquefaction were commonly observed in granular materials and Peck and Terzaghi (1948) named sudden flow under monotonic loading as "spontaneous liquefaction". Research efforts that focused on evaluating the liquefaction potential, and mitigating 
liquefaction induced damages, were significantly accelerated after the two catastrophic earthquakes in 1964; one in Niigata (Japan) and the other in Alaska. During the past decades, several liquefaction failures have been reported in the literature (Finn et al., 1991; Ishihara, 1996; Boulanger et al., 1998).

The shear strength of cohesionless soils is entirely dependent upon the effective stress, and therefore liquefaction poses a major hazard, especially to such soils because it may lead to a complete collapse of the infrastructure built upon and around such soils. Numerous studies based on field and laboratory analyses have been presented in the past few decades for better understanding and evaluating the liquefaction potential in sandy soils (Castro, 1969; Seed et al, 1983; Vaid and Chern, 1985; Ishihara, 1993; Vaid and Sivathayalan, 2000). In current practice, the NCEER guidelines (Youd et al., 2001) are widely accepted as the well-defined criteria for evaluating the liquefaction potential of sands, based on field test parameters such as SPT, CPT, shear wave velocity and BPT.

Unlike sandy soils, liquefaction is not observed as commonly in clayey soils, and therefore, based on the initial understanding and the classical definitions of liquefaction, it was assumed that clayey soils have no potential for liquefaction (Seed, 1979; Seed et al, 1983). The presence of cohesion in clayey soils does not allow for complete separation of soil particles during rapid undrained loading. As a result, zero shear strength state and unlimited deformation do not occur in clay (Ishihara, 1996). However, in current practice, the definition for liquefaction has evolved to include "significant strength loss and unacceptable deformations". In this sense, many cases of liquefaction of cohesive soil have been reported all over the world (Wang, 1979; Youd et al., 1985; Tuttle et al., 1990; Boulanger et al., 1998; Bray et al., 2004 (a); Bray et al., 2004 (b)). 
Seed et al. (1983) highlighted the well documented "Chinese criteria" for liquefaction of cohesive soils based on Wang's (1979) research around China. According to Chinese criteria, soils that satisfy the following three characteristics are vulnerable to severe strength loss during the event of earthquake shaking.

1. Percent finer than $0.005 \mathrm{~mm}<15 \%$

2. Liquid limit $<35$

3. Water content $>0.9 \times$ Liquid limit

The Chinese criteria were modified by Finn et al. (1987) to account for the North American practice. Later on, many liquefaction case histories such as Adapazari city in 1999 Kocaeli (Turkey) earthquake and the cities of Wu Feng, Yuan Lin and Nantou in the 1999 Chi-Chi (Taiwan) earthquake questioned the validity of the modified Chinese criteria (Seed et al., 2003). Using certain case studies as examples, Bray et al. 2001 and Sancio et al.; 2002 clearly proved that liquefaction can occur in clayey soils with "percent of clay fines" more than $15 \%$. Therefore, it was realized that the "percent of clay fines" is not a strong factor to represent the liquefaction potential of cohesive soils. It was recognized that the type of clay minerals dominates the behavior of soil, and has to be considered. Based on the previous case histories and experimental studies, Seed et al. (2003) proposed a new criterion for evaluating the liquefaction potential of cohesive soils using Atterberg limits (Figure 2.1). The new criteria defined the following three different zones:

Zone A: The soil is potentially susceptible to "Classic cyclically induced liquefaction" if $\mathrm{PI} \leq 12, \mathrm{LL} \leq 37$ and water content $>0.8 \mathrm{LL}$

$>$ Zone B: The soil may be liquefiable, further laboratory tests required if $12<\mathrm{PI} \leq$ $20,37<\mathrm{LL} \leq 47$ and water content $>0.85 \mathrm{LL}$ 
Zone C: The soil is not commonly susceptible to "Classic cyclic liquefaction" if PI $>20$ and LL $>47$. But in sensitive clays significant strength loss and liquefaction is possible.

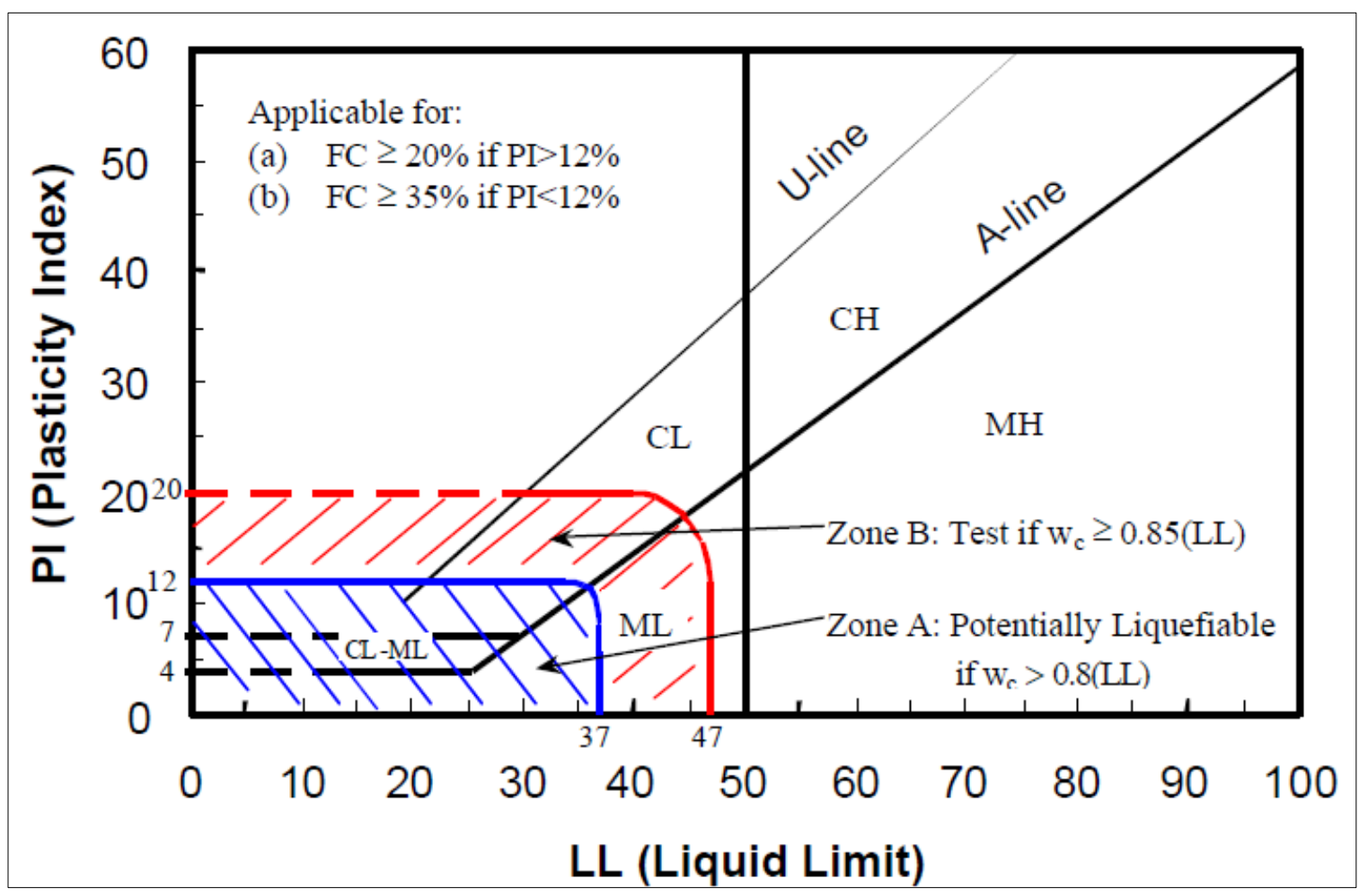

Figure 2-1 Recommendations regarding assessment of "Liquefiable" soil types (after Seed et al, 2003)

However, the criteria proposed by Seed et al (2003) also has its limitations and does not reliably resolve the uncertainty involved in the assessment of liquefaction potential of cohesive soils. In this regard, conducting laboratory tests on high quality undisturbed clay samples is the most reliable method to evaluate liquefaction potential in clayey soils (Boulanger and Idriss, 2004, 2006). 


\subsection{Sensitive clays}

Sensitive clay or quick clay loses its shear strength significantly when its original structure is disturbed/remolded (Skempton and Northey, 1952). Such behavior may cause landslides during earthquakes, and leads to severe damages in the structures founded on quick clay. Such clays are commonly found in the upper regions of the northern hemisphere such as Canada, Norway, Russia, Sweden and Alaska. To represent the strength reduction potential of clay, Terzaghi (1944) defined the term "Sensitivity" $\left(\mathrm{S}_{\mathrm{t}}\right)$ as the ratio between undisturbed strength of the clay to re-molded strength.

$$
S_{t}=\frac{\text { Undisturbed Strength }\left(S_{u}\right)}{\text { Remoulded Strength }\left(S_{u r}\right)}
$$

Rosenqvist (1946) explained the theory that the leaching of salt content in marine clay is the process that leads to the formation of sensitive clay. Here "leaching" implies the process of washing out the dissolved salts from the soil profile. The structure of marine clay is formed with a certain amount of salt content, but leaching may decrease this content with time. Once the salt is leached and the clay is disturbed, it cannot revert back to its initial structure. This reduces the water retaining capacity of the clay and may cause it to behave like a liquid. Therefore, the remolded shear strength of such clays can reduce significantly.

Experimental studies have also demonstrated that low salt content is indeed a primary condition for the formation of quick clay but it alone is not sufficient (Penner, 1965; Talme, 1968; Soderblom, 1969). The ion composition of the pore water is another factor which affects the formation of sensitive clays. Normally a clay leached by hard water (which contains $\mathrm{Ca}^{2+}$ and $\mathrm{Mg}^{2+}$ as dominating ions) will not turn into quick clay, but a clay leached by soft water (which contains $\mathrm{Na}^{+}$as the dominating ion), will enhance 
the possibility of quick clay formation (Sôderblom, 1974; Fällman et al., 2001). It has been observed that glacial clay deposits are usually found in the areas which have limestone in the surrounding bedrocks, and post-glacial clay is deposited directly above these glacial layers. Therefore, glacial clay contains large amount of calcium carbonate compared to post-glacial clay. As a result, the formation of quick clay is most common in post-glacial clay deposits (Talme, 1968). Skempton and Northey (1952), proposed the first sensitivity classification (Table 2.1) to categorize clays based on their sensitivity index.

Table 2-1 Sensitivity classifications in Skempton and Northey (1952)

\begin{tabular}{|l|l|}
\hline Sensitivity (St) & Definition \\
\hline 0 to 1 & Insensitive clays \\
\hline 1 to 2 & Clays of low sensitivity \\
\hline 2 to 4 & Clays of medium sensitivity \\
\hline 4 to 8 & Sensitive clays \\
\hline$>8$ & Extra-sensitive clays \\
\hline$>16$ & Quick-clays \\
\hline
\end{tabular}

Later on, several sensitivity classifications were proposed by various researchers (e.g. Rosenqvist, 1953; Rankka et al., 2004). Canadian Foundation Engineering Manual CFEM (2006, $4^{\text {th }}$ edition) proposed the following sensitivity guideline for Canadian geotechnical practice. 
Table 2-2 Sensitivity Classifications in the CFEM (2006, 4th edition)

\begin{tabular}{|l|l|}
\hline Sensitivity $\left(\mathbf{S}_{\mathbf{t}}\right)$ & Definition \\
\hline $\mathrm{S}_{\mathrm{t}}<2$ & Low sensitivity \\
\hline $2<\mathrm{S}_{\mathrm{t}}<4$ & Medium sensitivity \\
\hline $4<\mathrm{S}_{\mathrm{t}}<8$ & Sensitive \\
\hline $8<\mathrm{S}_{\mathrm{t}}<16$ & Extra - sensitive \\
\hline $\mathrm{S}_{\mathrm{t}}>16$ & Quick clay \\
\hline
\end{tabular}

\subsection{Undrained monotonic loading of soil}

\subsubsection{Undrained monotonic behaviour of sand}

Undrained monotonic behaviour of saturated sand has been studied extensively by several researchers under triaxial loading conditions (e.g. Lee and Seed, 1967; Castro, 1969; Ishihara, 1993; Vaid and Thomas, 1994), and a unique relationship has been observed between the response and the relative density of the specimen (Figure 2.2). The stress-strain behaviour of saturated sands is mainly classified into three different types (Types 1, $2 \& 3$ ) based on the initial state of the soil (Loose, medium and dense relative densities).

Shear strength of loose sand (Type 1) increases up to a clear peak value with increasing shear strain then decreases and reaches a constant value. Loading the specimen after it reaches its peak strength mobilizes very large strains and leads to catastrophic failure rapidly. At the ultimate state, shear deformation occurs in Type 1 materials at a constant normal effective stress, constant shear stress and at a constant value of void ratio. This state is referred to as the steady state (SS) of deformation or flow deformation, and the corresponding shear strength is known as the steady state strength. 


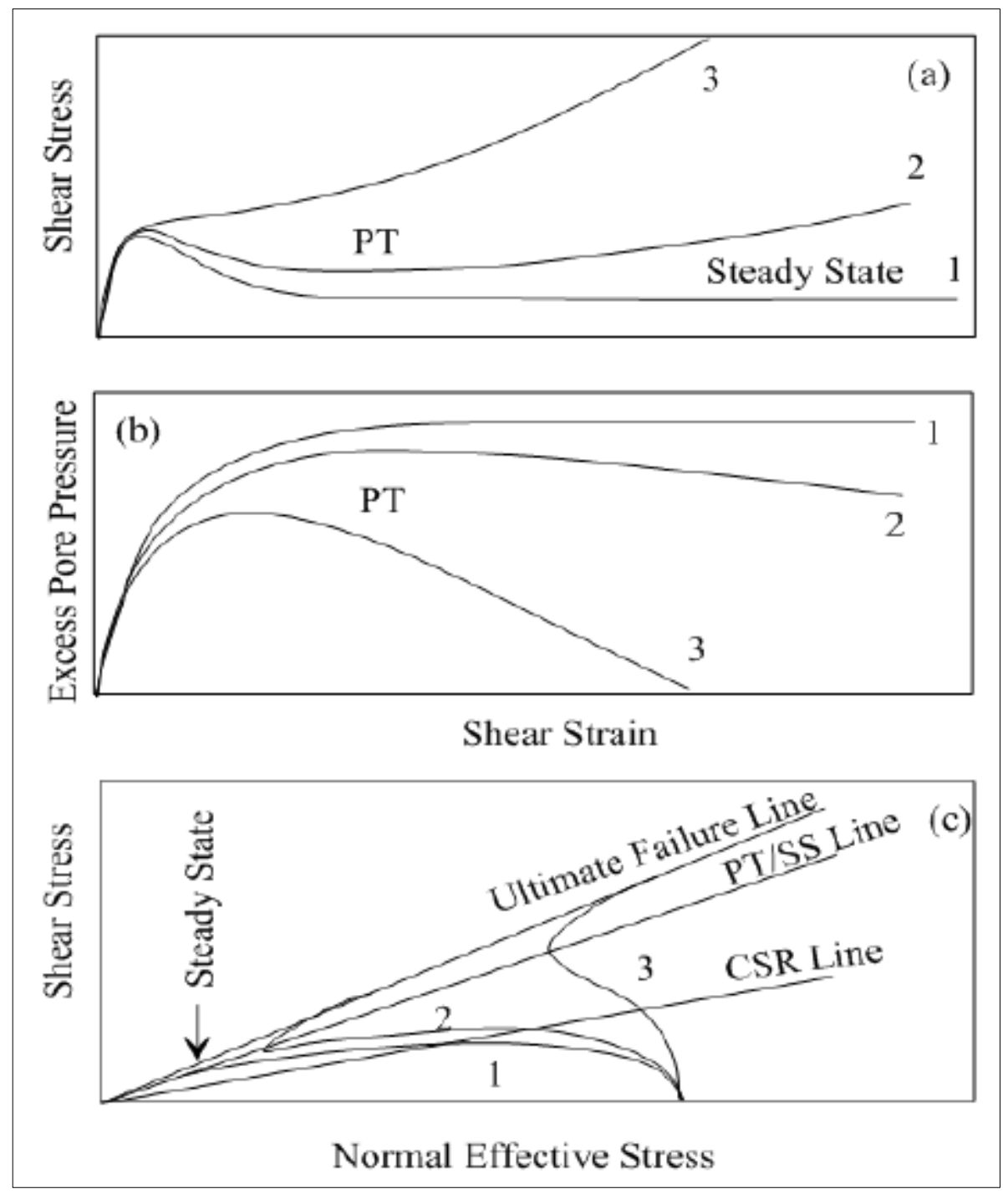

Figure 2-2 Undrained monotonic response of saturated sands (After Chern, 1985)

Pore water pressure initially increases with loading and then reaches a constant value during the steady state in type 1 response. For a specimen of particular density, the ultimate deformation starts to occur at a particular stress state (constant normal and shear stress condition), and therefore the locus of such points for the specimens at different densities, is referred to as the steady state line in the stress path or $e-\log (p)$ plot. Castro (1969) named type 1 response as liquefaction, and later Chern (1985) termed it as "true liquefaction" to clearly distinguish it from the type 2 response. 
The shear strength of medium dense sand reaches a peak value and shows strain softening (contractive) similar to loose sand until a moderate level of strain. However, after reaching a moderate strain level, the strain softening behaviour transforms to strain hardening behaviour and the specimen starts to regain its shear strength. The corresponding point where the specimen changes its behaviour from contractive to dilative essentially coincides with the minimum shear strength point which is unique for a specimen at given density (occurs at constant stress and void ratio). This state is called the phase transformation (Ishihara et al., 1975). Corresponding minimum shear strength state is called the Quasi Steady State (QSS), and after this point the pore water pressure starts to decrease. Lee and seed (1967) named the 'type 2' response as 'partial liquefaction', while some researchers called it as 'limited liquefaction' (Castro, 1969; Vaid and Chern, 1985).

Dense sand follows the 'type 3 ' stress strain response, in which it shows contractive behaviour for initial small strain level and dilative behaviour subsequently. It does not show a peak value and the shear strength of sand continuously increases with increasing strain level. Dense specimens develop large negative pore water pressure for a wide range of strain levels. This type of response is named as strain hardening.

Apart from the relative density, the soil fabric, initial stress state and the loading mode affect the response of sands. For soil samples at similar initial stress states, increasing the relative density from loose to dense state will change the undrained response from 'type 1' to 'type 3' behaviour for a particular loading mode (Vaid and Thomas, 1995; Vaid and Sivathayalan, 1996; Uthayakumar and Vaid, 1998). Also, increasing the confining stress results in the soil behaviour shift from dilative to 
contractive, while keeping other factors constant (Been et al., 1991; Vaid and Thomas, 1995; Vaid and Sivathayalan, 1996; Uthayakumar and Vaid, 1998).

Generally, soil is naturally deposited with inherently anisotropic fabric under the force of gravity. It is stronger when the loading is in a direction perpendicular to the bedding plane and weaker when it is parallel. Therefore, the soil response is heavily influenced by the loading mode. Mostly, sand shows a dilative response (regardless of the relative density) in triaxial compression (TC) loading (even at loose states), whereas it shows contractive response in the triaxial extension (TE) loading, even at relatively dense state (Vaid and Sivathayalan, 2000). Different type of specimen preparation methods produces different type of soil fabric and this results in a different responses. It has been noted that water pluviated samples are more uniform and closely represent the undisturbed sand specimens from alluvial environments compared to air pluviated and moist tamp prepared samples (Vaid et al., 1999; Sivathayalan and Vaid, 2004).

\subsubsection{Undrained monotonic behavior of Clay}

Monotonic undrained behavior of clays has been studied in great depth in the literature (Roscoe et al, 1958; Bishop, 1966; Ladd and Foott, 1974; Silvestri et al., 1989; Ladd, 1991). Normally clays have very low permeability and the dissipation of pore water pressure is very slow during loading. Therefore, most of the loading (in the "short term") could be considered as undrained. The undrained shear strength of saturated clay is defined as, $C_{u}=0.5\left(\sigma_{1}-\sigma_{3}\right)$ with no friction $\left(\emptyset_{u}=0\right)$ (Skempton, 1948).

As the strain increases, the monotonic shear strength of clay also increases and reaches a nearly constant value. Unlike sand, the type of stress-strain behavior of clay 
mainly depends on its OCR, i.e., the Over Consolidation Ratio. Normally consolidated clay shows a contractive behavior similar to loose sand, in which the shear strength of clay reaches almost a constant value with a steadily increasing pore water pressure. On the other hand, overly consolidated clay shows a dilative behavior in which the pore water pressure decreases below zero after a positive value at the very small strain range.

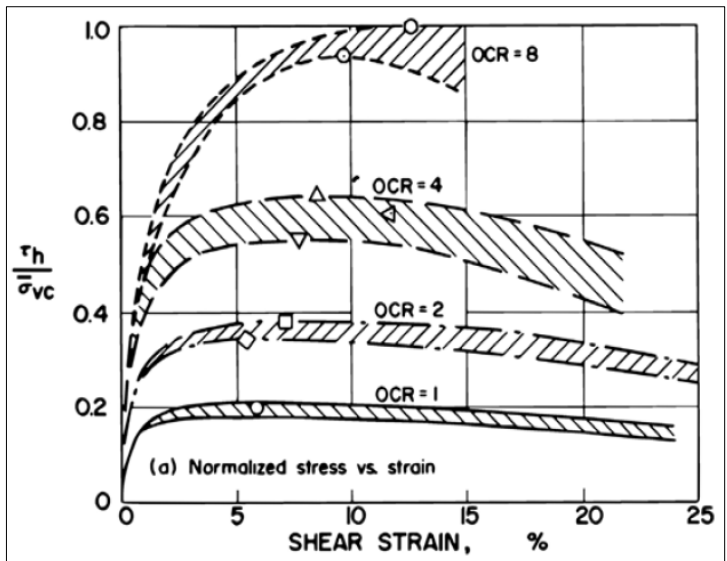

Figure 2-3 Typical undrained monotonic response of clay (after Ladd \& Foott, 1974)

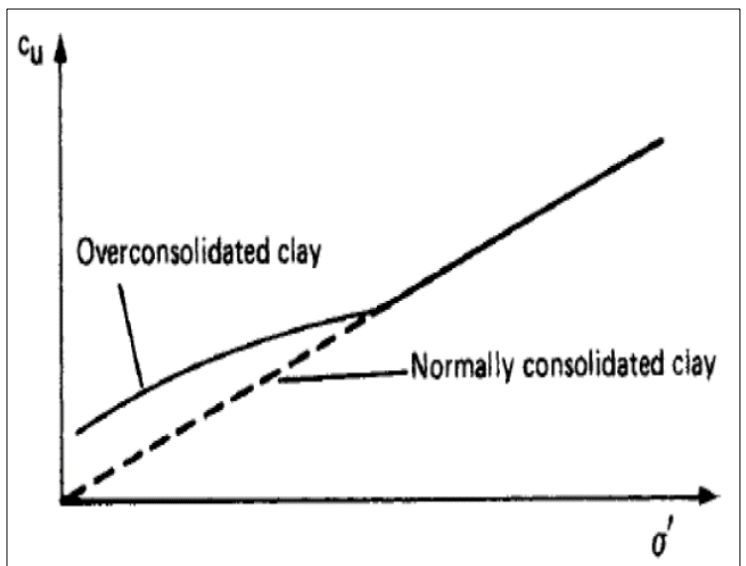

Figure 2-4 Typical undrained strength variation with consolidation pressure (after Craig, 2004)

Apart from OCR, the undrained monotonic behaviour of clay depends on several factors such as the initial effective stress state, stress path, strength anisotropy and strain rates. Undrained monotonic peak strength of clay $\left(\mathrm{S}_{\mathrm{u}}\right)$ increases with increasing OCR ratio (Figure 2.3). Generally, in normally consolidated clays $\mathrm{S}_{\mathrm{u}}$ increases linearly with the consolidation pressure but the relationship is nonlinear in over consolidated clays as shown in Figure 2.4 (Ladd and Foott, 1974; Craig, 2004). Using the "Stress History and Normalized Soil Engineering Properties (SHANSEP) testing method", Ladd and Foott (1991) evaluated the $S_{u} /_{\sigma^{\prime}{ }_{v c}}$ values ( $\sigma^{\prime}{ }_{v c}$ is the vertical effective consolidation stress) at different OCR levels and proposed the following equation.

$$
S_{u}{/ \sigma^{\prime}{ }_{v c}}=S(O C R)^{m}
$$


Where $S$ is the normally consolidated value of $S_{u} / \sigma^{\prime}{ }_{v c}$

Unlike in sand, straining rate does affect the undrained shear strength of clay. The permeability of clay is very low which can result in an unequal distribution of porewater pressure in the sample during a high strain rate of loading. Therefore, a suitable rate of strain should be chosen to allow for sufficient time to develop equalized porewater pressure throughout the specimen. The suitable strain rate is mainly dependent on the permeability of the clay and could be estimated from the following equation (ASTM, D 4767-95).

$$
\text { Strain Rate }=\text { Failure Strain } \% / 10 t_{50}
$$

where $t_{50}$, i.e., the time for $50 \%$ primary consolidation and can be calculated from the procedure given in ASTM D 2435. Normally the undrained shear strength of clay increases by about $5 \%-15 \%$ when the strain rate is increased by a log cycle (Taylor, 1943; Casagrande and Wilson, 1951). Figure 2.5 shows the effect of strain rate on the undrained monotonic strength of Mexico City clay (Díaz-Rodríguez at el., 2009). In the research, they also concluded that the axial strain at peak deviatoric stress is independent of the strain rate and that the normalized strength increment with strain rate is higher in OC clays than in NC clays.

Soil anisotropy, loading mode and static shear effects on undrained shear strength of clay are similar to the effects discussed in sands. 


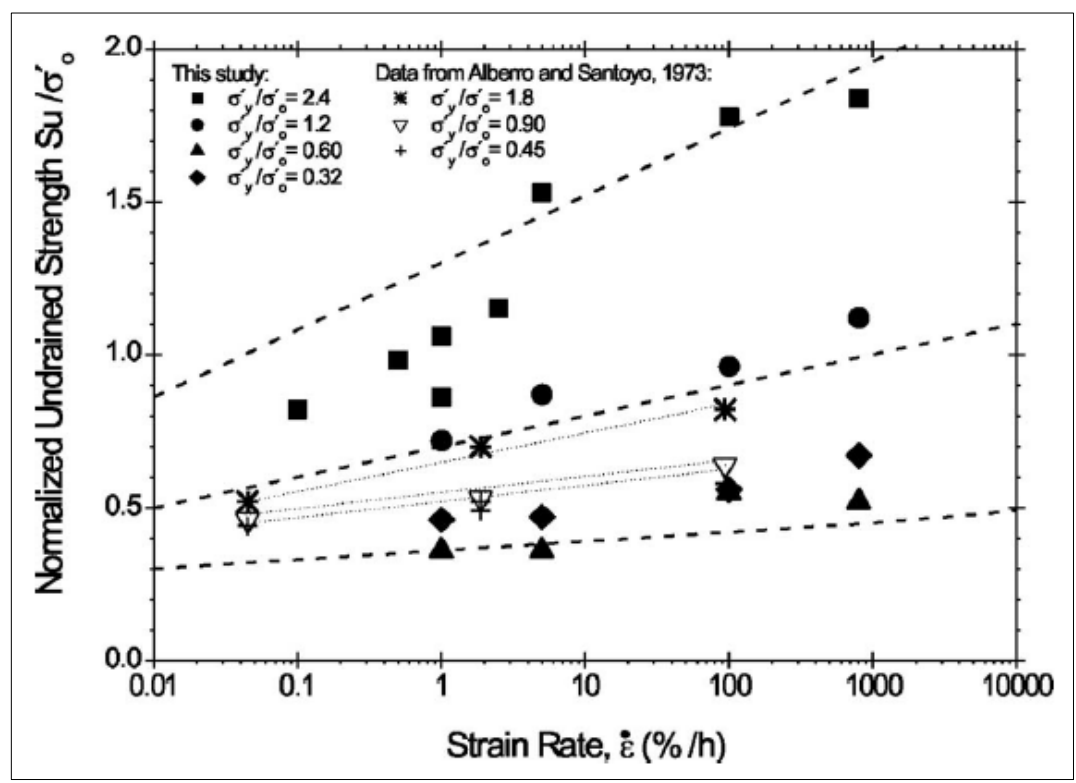

Figure 2-5 Variation of normalized undrained shear strength with strain rate (after DíazRodríguez at el., 2009)

\subsection{Undrained cyclic loading of soil}

The undrained cyclic loading condition in soil is very common during earthquakes. Such loading can be expressed in terms of the magnitude, frequency content, loading duration, etc. and is dependent on several geological factors and the earthquake magnitude. Similarly, the response of the soil depends on its properties and can vary from site to site. Detailed laboratory and experimental studies have been presented in the literature by various researchers to understand the cyclic behavior of different types of soil during an earthquake loading (e.g. Sangrey et al., 1969; Andersen et al., 1988; Ansal and Erken, 1989; Zergoun and Vaid, 1994; Boulanger and Idriss, 2004).

Typically, rapid cyclic loading in undrained soil continuously increases the porewater pressure and simultaneously decreases the effective stress of soil. The shear deformation increases with the number of loading cycles and may trigger liquefaction in 
the soil. Zergoun and Vaid (1994) pointed out that the cyclic stress magnitude above a certain threshold value progressively generates pore water pressure and simultaneously reduces the effective stress. This conclusion was drawn while conducting undrained cyclic triaxial testes on normally consolidated Cloverdale clay. Also, they observed that during cyclic loading, the stress path migrates towards the origin and the clay fails when it touches its monotonic failure effective stress path (Figure 2.6). Furthermore, significant reduction in the shear modulus and consciously enlarged stress-strain hysteresis loop was also observed with increasing number of cycles. The undrained cyclic behavior of soil depends upon many factors, and some important factors are discussed below.

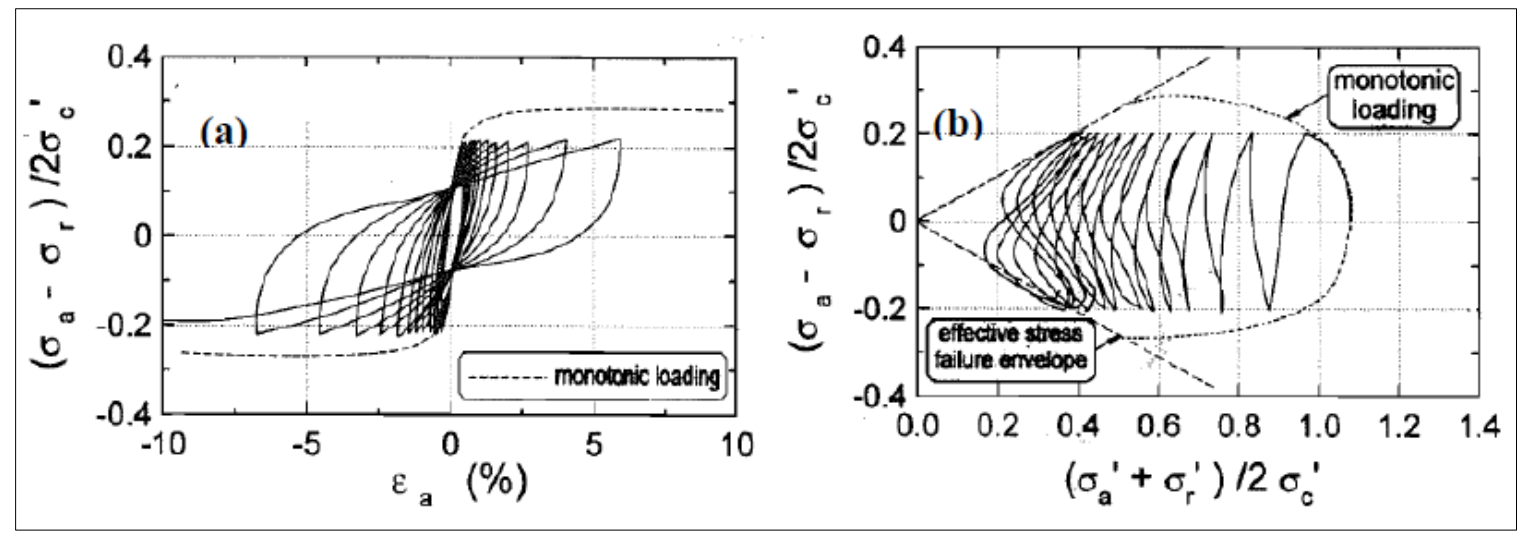

Figure 2-6 Stress - Strain and Effective stress path plots of undrained cyclic test of saturated clay (After Zergoun and Vaid 1994)

\subsubsection{Cyclic stress / strain amplitude}

The cyclic behaviour of soil mainly depends upon the relative value of the cyclic shear stress amplitude $\left(\tau_{c y c}\right)$ with respect to the shear strength (or effective confining pressure) and many studies have been conducted in the literature to evaluate its influence. (e.g. Larew and Leonards, 1962; Sangrey et al., 1969; Mitchell and King, 1976; Lefebvre et al., 1989; Zergoun and Vaid, 1994). Regardless of the number of cycles, significant pore water pressure generation or significant strain accumulation is not observed in clays 
below a certain amplitude of cyclic stress magnitude. This value of cyclic stress amplitude has been called the threshold stress. In other words, cyclic stress amplitude above the threshold value could generate significant pore water pressure with each loading cycles and could eventually lead to failure with increasing number of loading cycles.

Mitchell and King (1976) conducted undrained triaxial cyclic testes on undisturbed sensitive clay samples from Ottawa area. From the test results, they concluded that there exists a threshold stress amplitude and in the sensitive Champlain sea clay, the cyclic deviatoric stress amplitude $\left(\tau_{c y c}\right)$ of above $50 \%$ of the static strength $\left(S_{u}\right)$ of the clay is required to fail the sample. Similarly, from the experimental studies conducted with two-way undrained cyclic triaxial loading (loading with stress reversal) on normally consolidated undisturbed marine clay (Cloverdale clay), Zergoun and Vaid (1994) stated that the cyclic stress amplitude of $55 \%$ of $S_{u}$ is required to fail the sample in cyclic loading. Furthermore, Houston and Herrmann (1980) reported that the threshold cyclic stress value of marine clays varies from $18 \%$ to $90 \%$ of their $S_{u}$, and it increases with the Plasticity Index (PI).

Similar to the threshold cyclic shear stress amplitude, some researchers have attempted to find the threshold cyclic shear strain $\left(\gamma_{t}\right)$ (Vucetic, 1994; Hsu and Vucetic, 2006). There is no significant accumulation of pore water pressure while the soil experiences a cyclic strain amplitude smaller than the threshold value regardless of number of loading cycles. Depicting the test results for five different types of soil, Hsu and Vucetic (2006) reported that the $\gamma_{t}$ in cohesive soils is larger than that in cohesionless soils. 


\subsubsection{Number of loading cycles}

For a given cyclic stress amplitude above the threshold value, every loading cycle contributes to the pore water pressure build up and causes the stress-strain behaviour of soil to tilt towards the failure line observed in the cyclic loading pattern. In reality, earthquakes generate very irregular cyclic loading pulses, but it is often simplified to a certain number of uniform sinusoidal loading cycles (N) with some cyclic stress

amplitude $\left(\tau_{\text {cyc }}\right)$ value based on the intensity of the earthquake (Seed and Idriss, 1982). The number of uniform sinusoidal loading cycles $(\mathrm{N})$ required to represent an earthquake of magnitude $\mathrm{M}_{\mathrm{w}}$ have been proposed by many researchers. The relationship proposed by Boulanger and Idriss (2004) is commonly accepted (Figure 2.7). Typically, earthquake loads can trigger 1 to 40 uniform sinusoidal loading cycles.

The cyclic resistance of soil is often described as the maximum number of loading cycles $(\mathrm{N})$ that the soil can withstand for a certain value of cyclic stress ratio,CSR defined as the ratio of cyclic shear stress to the effective confining pressure. For an undrained cyclic triaxial loading, the CSR value reduces hyperbolically with the increasing number of loading cycles and is defined as

$$
C S R=\frac{\sigma_{c y c}^{\prime}}{2 \sigma^{\prime}{ }_{3 c}}
$$

Where $\sigma^{\prime}{ }_{c y c}$ is effective cyclic deviatoric stress and $\sigma^{\prime}{ }_{c}$ is effective confining pressure. 


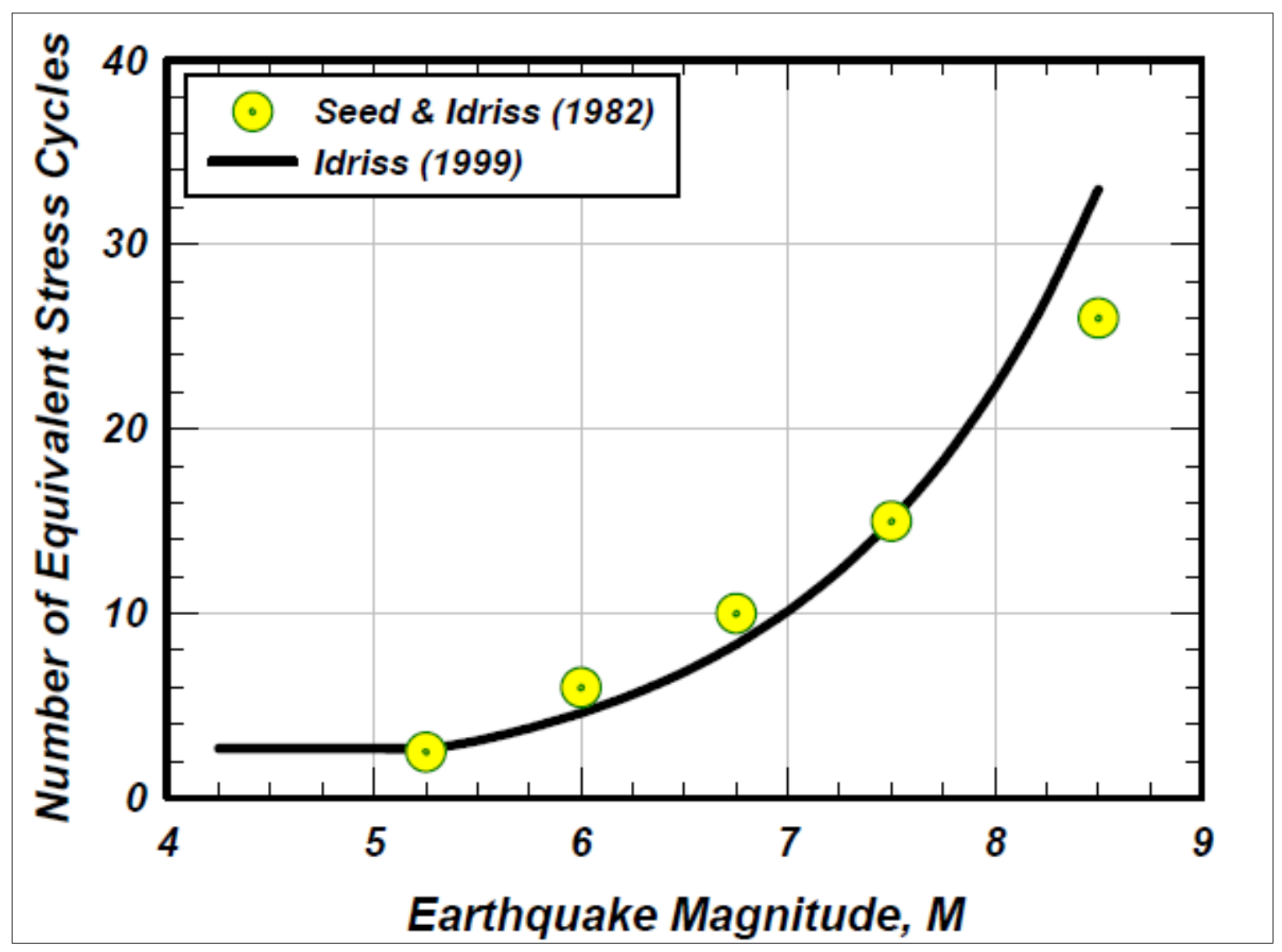

Figure 2-7 Relationship between earthquake magnitude and number of loading cycles (after Boulanger and Idriss, 2004)

\subsubsection{Effective confining pressure}

It has been observed that the soils experiencing high confining pressure tend to display a contractive response and generate higher pore water pressure (Vaid and Chern, 1985; Vaid and Thomas, 1994). Therefore, increasing the confining stress reduces the cyclic resistance of soils. Mitchell and King (1976) conducted undrained cyclic loading tests on Champlain sea clay at different confining stresses and observed that the pore water pressure increased with effective confining stress, and also that the number of cycles required to cause failure reduced with the increasing confining stress. During the 1999 Kocaeli earthquake, Turkey, Bray and Sancio (2006) witnessed severe reduction in 
soil strength at locations near buildings compared to open sites. They also conducted undrained cyclic triaxial tests on undisturbed samples from Adapazari, Turkey at different confining stress levels (Figure 2.8). From these studies, they concluded that soils at high effective confining pressure are less resistant to cyclic shear failure (liquefaction).

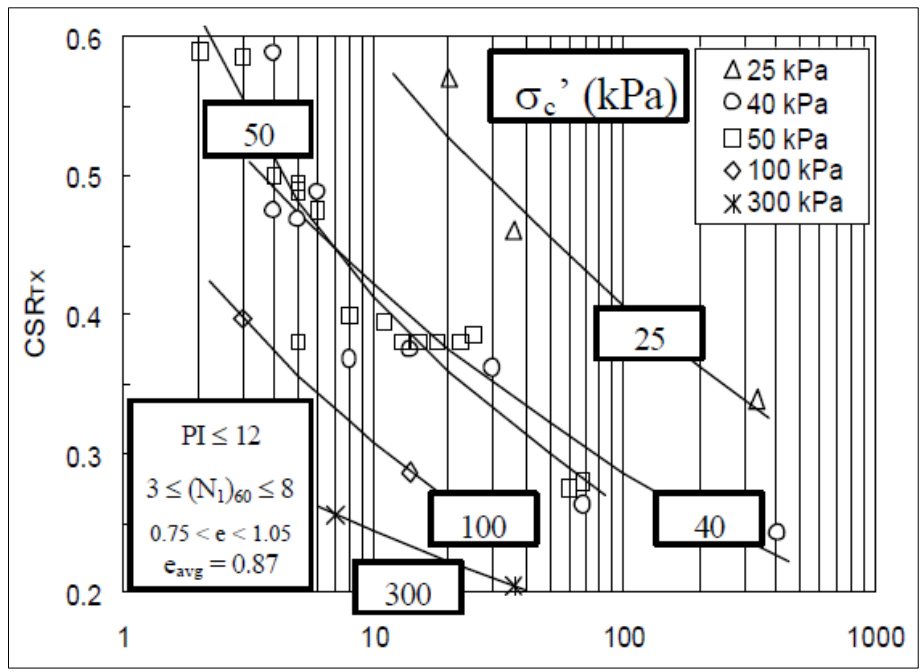

Figure 2-8 Influence of effective confining stress on cyclic failure (after Bray and Sancio, 2006)

\subsubsection{Over consolidation ratio (OCR)}

The stress history of soil significantly influences its cyclic behaviour. Normally consolidated clays (NC) generate positive pore water pressure while overly consolidated clays (OC) generate some negative pore water pressure initially and then positive pore water pressure in subsequent loading cycles, eventually moving towards the failure line. Therefore, a higher OCR results in higher initial negative pore water pressure, and over consolidated soil also shows a higher cyclic resistance than normally consolidated soils (Ohara and Matsuda, 1988; Azzouz et al., 1989). Ishihara and Takatsu (1979) carried out undrained cyclic test on Fuji river sand for different OCR values, under torsional shear 
conditions. It was observed that the cyclic resistance of sand increases with increasing OCR values (Figure 2.9). Manmatharajan and Sivathayalan (2011) reported that OCR values significantly affect the liquefaction characteristics of Fraser River sand, and proposed a correction factor $K_{O C R}$ analogous to the $K_{\sigma}$ and $K_{\alpha}$ factors used in sands.

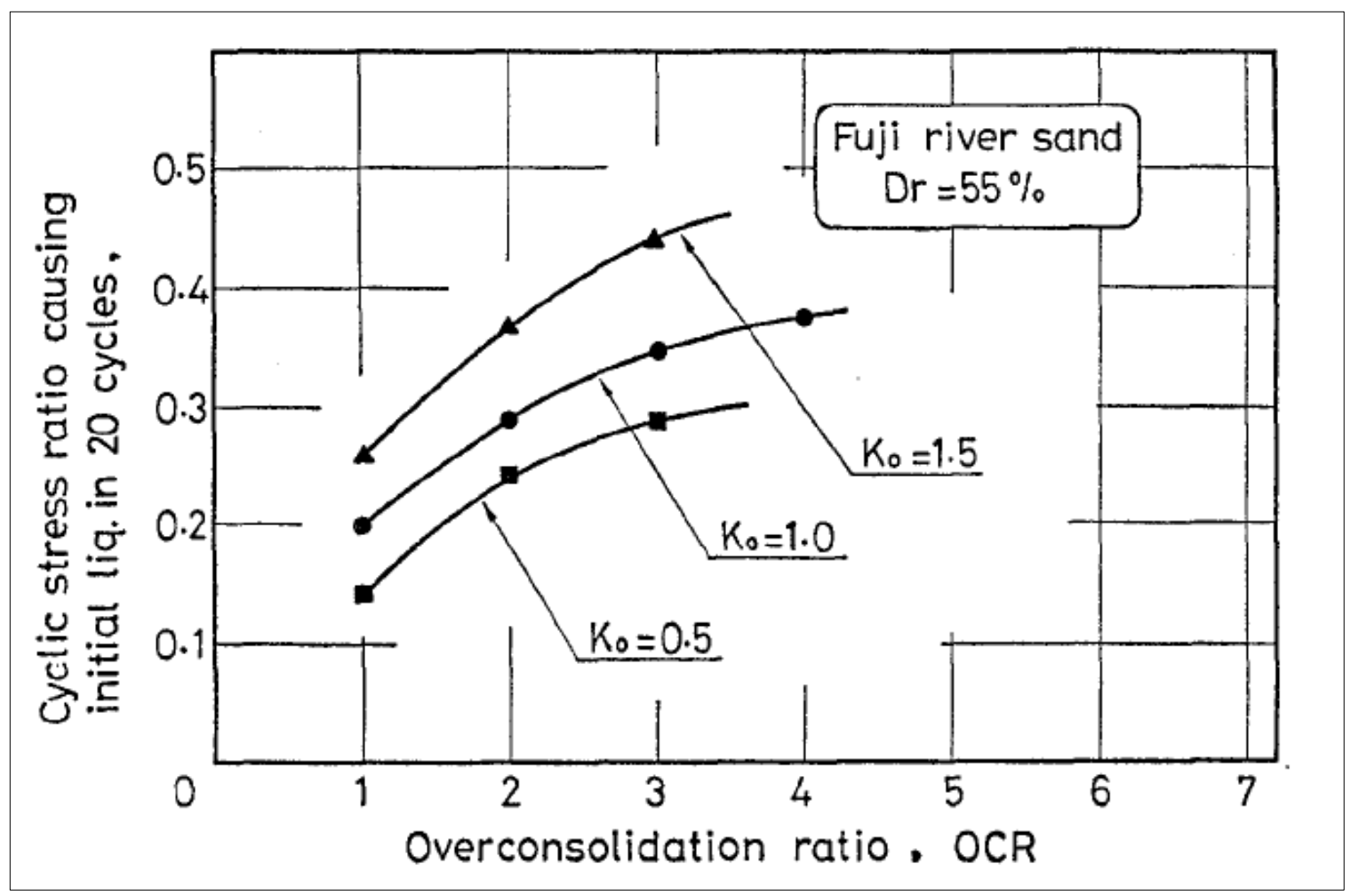

Figure 2-9 Influence of OCR on cyclic resistance of sand (after Ishihara and Takatsu, 1979)

\subsubsection{Loading conditions}

Similar to the static undrained response of soil, loading conditions influence the cyclic response as well. Different loading conditions are required to analyse the failure surface of soil in different situations (Figure 2.11). In laboratory, a simple shear device and a triaxial device are the two widely used apparatus to study cyclic resistance of soils. However, the loading conditions in these two devices are different and thus the cyclic 
resistance determined under one loading mode does not match the other. Even though the simple shear condition closely represents the field loading conditions during earthquakes the triaxial device is commonly used for conducting cyclic tests owing to its simple setup, straightforward usage and easy availability in the laboratory.

The CSR value while using a simple shear device is estimated as: ${ }^{\tau_{c y c}} / \sigma_{v c}^{\prime}$ and that while using a triaxial device is given by $\sigma^{\prime}{ }_{c y c} / 2 \sigma_{3 c}^{\prime}$. The latter is higher than the value obtained from a simple shear test. Seed and Peacock (1971) recommended a value of 0.6 for $C_{r}$, where $C_{r}$ is the ratio of CSR from a simple shear device to the CSR of a triaxial device. However, a detailed study conducted by Vaid and Sivathayalan (1996) for simple shear and triaxial testing of Fraser Delta sand reported that the $\mathrm{C}_{\mathrm{r}}$ value recommended by Seed and Peacock (1971) is overly conservative (especially in loose sands). They also claimed that $C_{r}$ is a function of confining stress in dense sand (Figure 2.10).

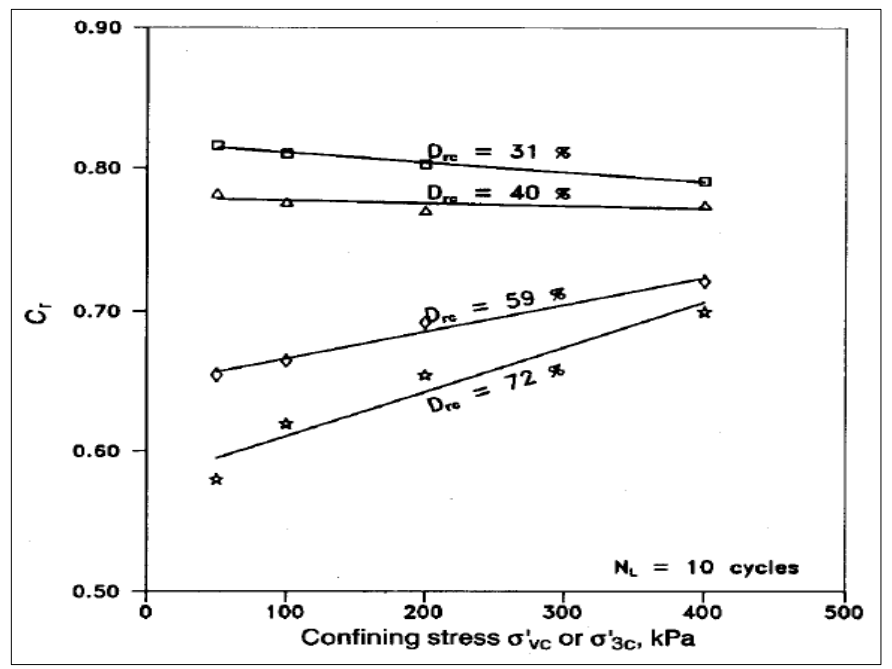

Figure 2-10 Variation of $C_{r}$ with confining stress in sand (after Vaid ans Sivathayalan, 1996) 


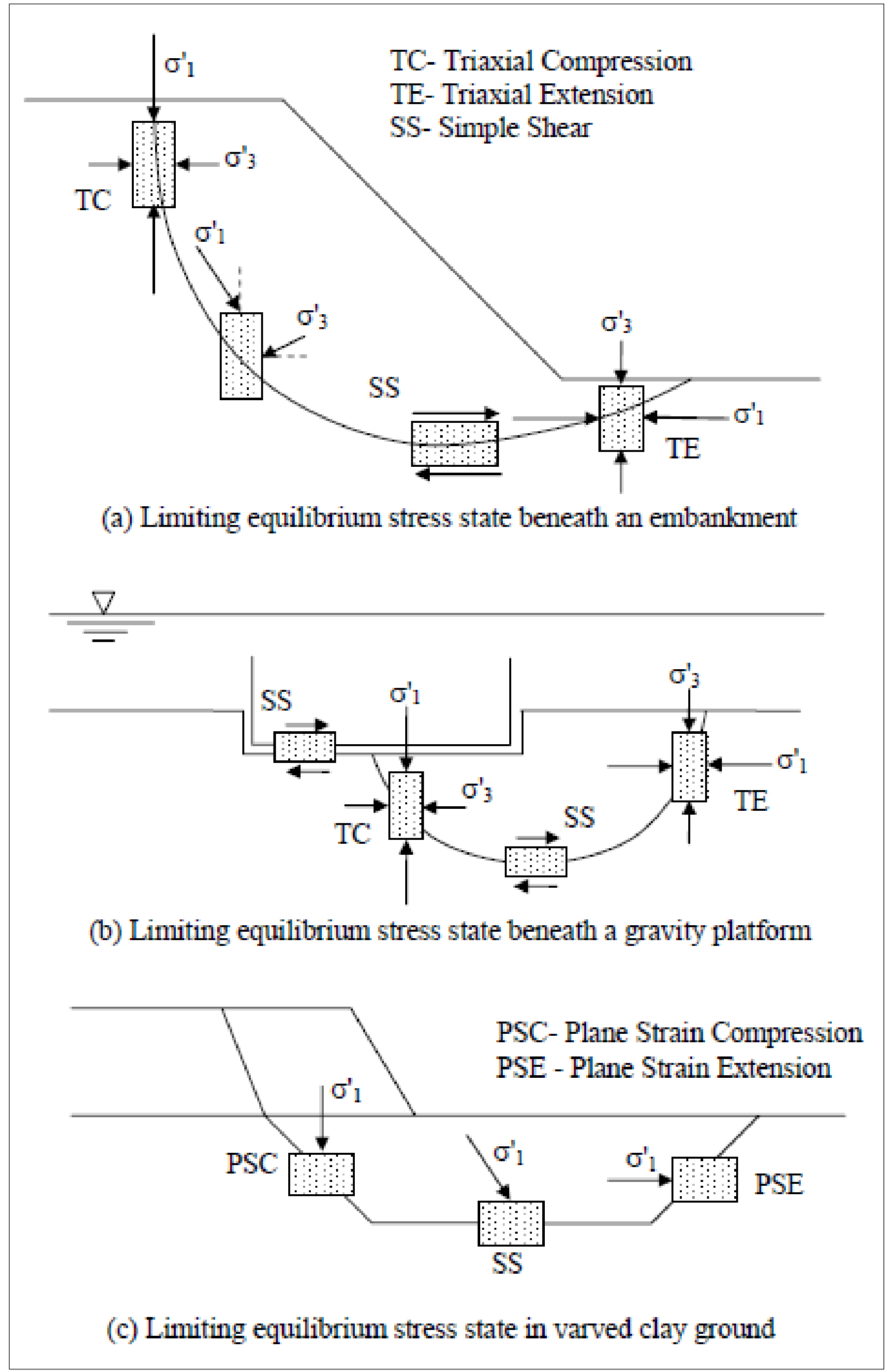

Figure 2-11 Different loading conditions along the potential failure surfaces (after Logeswaran, 2010) 


\subsection{Dynamic properties of soil}

Analyzing the response of soil for dynamic loading such as earthquake is a very challenging and important task for successful geotechnical design. Soil often amplifies the bedrock excitation to the ground surface and therefore most of the damage during earthquakes are induced by the dynamic response of soil deposits. In this regard, a reliable ground response analysis is critical to evaluate the liquefaction potential of soil and stability of other structures on the surface. The equivalent linear model is the simplest and widely used model to estimate the ground response of soils (Kramer, 1996). Accurate soil properties are required for successful modeling of soil.

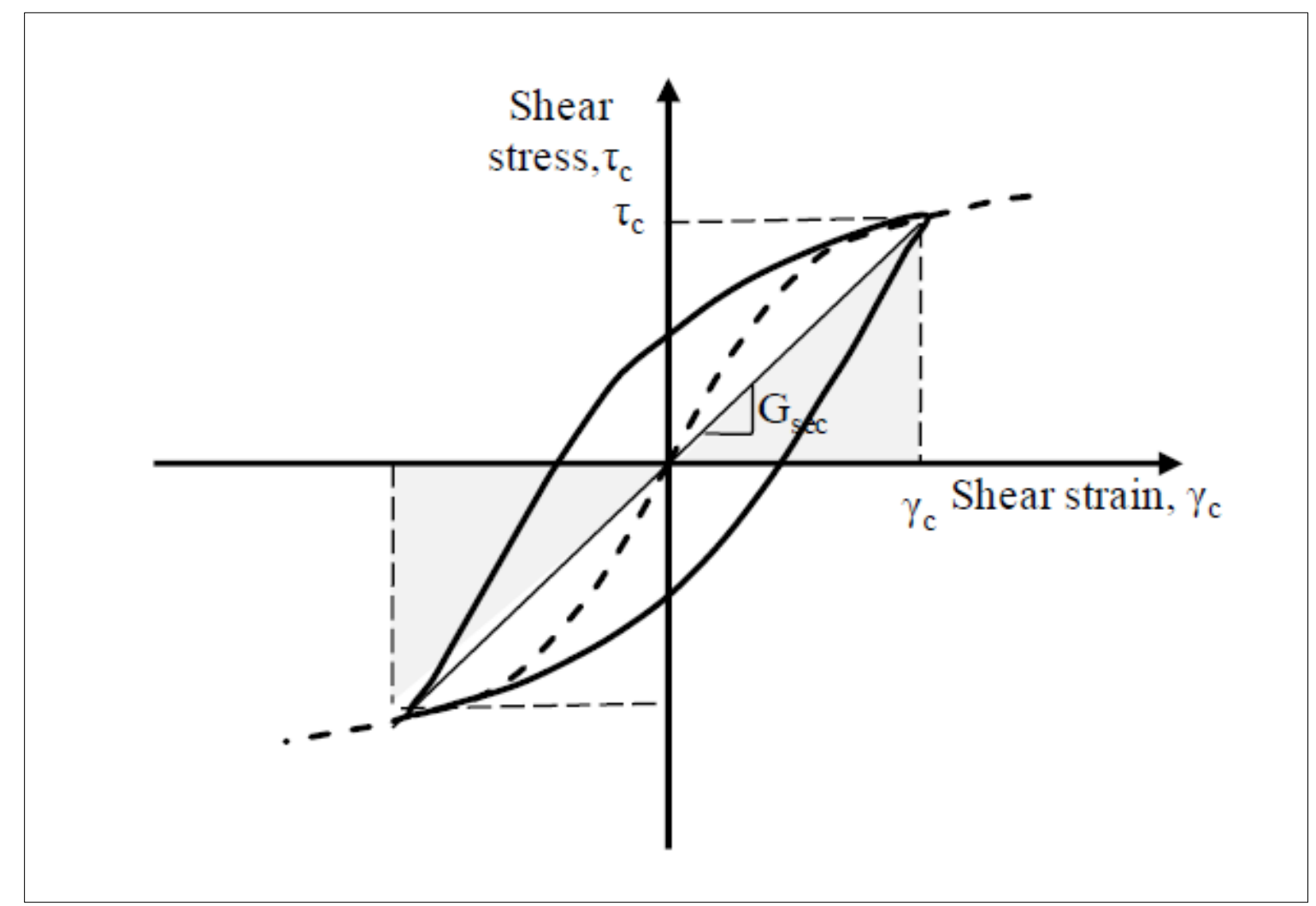

Figure 2-12 Typical hysteresis loop of soil during cyclic loading

A typical soil (free from structural loads) when experiencing a uniform cyclic loading is expected to show a hysteresis loop as shown in Figure 2.12. The characteristics of this loop can be described using two parameters, i.e., the inclination and the breadth of 
the loop. The inclination of the loop is related to the stiffness of soil. The average stiffness of soil (secant shear modulus, $G_{s e c}$ ) for a loop can be estimated by finding the slope of line connecting two extreme points of the loop

$$
G_{\text {sec }}=\frac{\tau_{c}}{\gamma_{c}}
$$

Here $G_{s e c}$ represents the general inclination of the loop, $\tau_{c}$ and $\gamma_{c}$ are cyclic shear stress and cyclic shear strain amplitude respectively.

The breadth of the loop is associated with its area which can be related to the dissipated energy. It is commonly represented by the viscous damping ratio $\xi$ through the following equation (Jacobsen, 1930; Kramer, 1996).

$$
\xi=\frac{W_{D}}{4 \pi W_{S}}=\frac{A_{\text {loop }}}{2 \pi G_{\text {sec }} \gamma_{c}^{2}}
$$

Where $\mathrm{W}_{\mathrm{D}}$ is the dissipated energy, $\mathrm{W}_{\mathrm{S}}$ is the maximum strain energy, and $\mathrm{A}_{\text {loop }}$ is the area of hysteresis loop.

The secant shear modulus $\left(\mathrm{G}_{\mathrm{sec}}\right)$ and the damping ratio $(\xi)$ are two important input parameters when modelling a soil using the equivalent linear model. Even though the equivalent linear model is an approximation of the actual nonlinear behavior of soil, using reasonable measurements of $\mathrm{G}_{\mathrm{sec}}$ and $\xi$ give reliable results for ground response analysis with efficient computational models. These parameters can be estimated by using laboratory tests with reasonable accuracy. The resonant column test and the bender element test are preferred to measure $G_{s e c}$ and $\xi$ at lower strain levels, while the cyclic triaxial test, simple shear test, and the cyclic torsional shear test are recommended for larger strain amplitudes (Kim and Novak, 1981; Vucetic and Dobry, 1988, 1991; Woods, 1994). 


\subsubsection{Secant shear modulus $\left(G_{\text {sec }}\right)$}

The secant shear modulus of soil is often represented as a function of the cyclic shear strain amplitude $\left(\gamma_{c}\right)$. It has a high value at very low strain level and decreases with increasing strain. A curve connecting the tips of hysteresis loop of varies cyclic strain amplitudes called as "Backbone curve" (Figure 2.13 a). The slope of this curve at the origin represents the "maximum shear modulus $\left(G_{\max }\right)$ ". For convenience, geotechnical engineers often use the "modulus reduction curve", i.e., the variation of $G_{s e c} / G_{\max }$ with $\gamma_{c}$, instead of the backbone curve (Figure 2.13 b). The modulus reduction curve and $G_{\max }$ are sufficient parameters to characterize the stiffness of soil in an equivalent linear model.

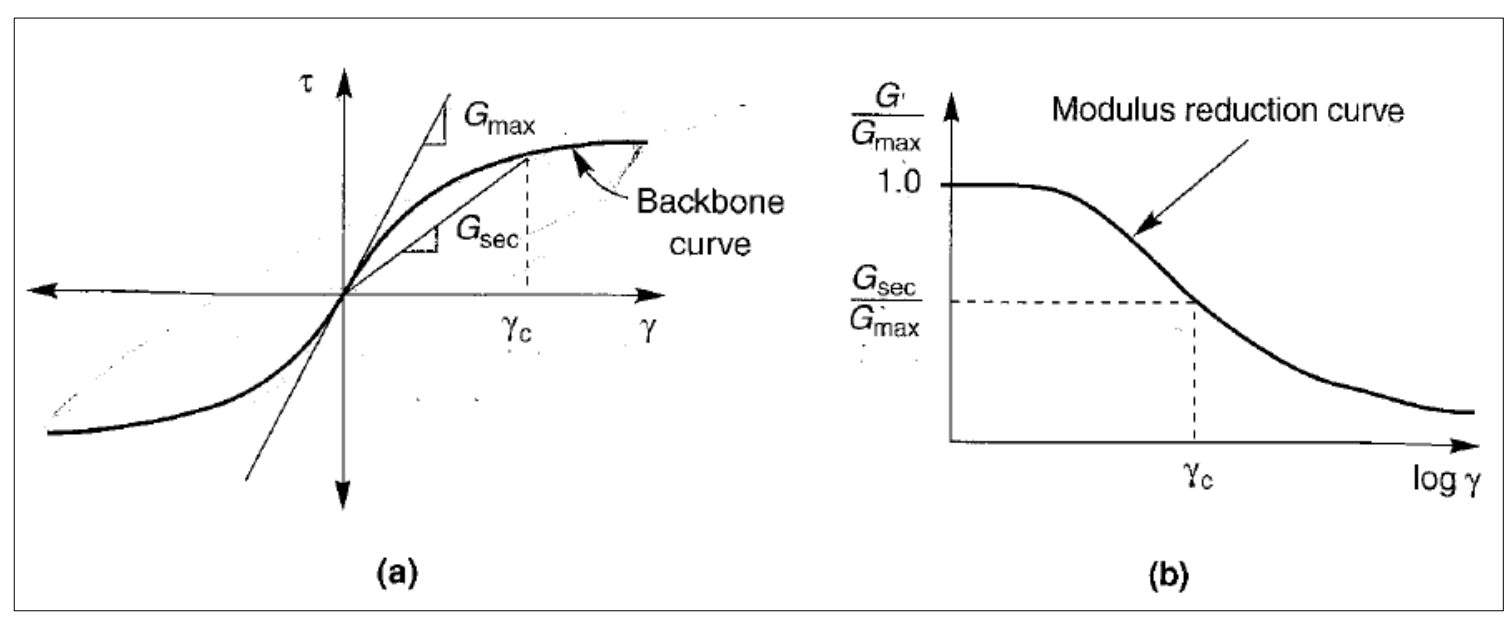

Figure 2-13 Backbone curve and typical modulus reduction curve of soil (after Kramer, 1996)

\subsubsection{Maximum Shear Modulus $\left(G_{\max }\right)$}

The maximum shear modulus is an important parameter in soil dynamic analysis. It is the maximum value of shear modulus measured at a very small elastic range of strain levels (commonly at shear strain level lower than $0.0001 \%$ ). In practice, $G_{\max }$ can be easily estimated by measuring the shear wave velocity of soil (Yan and Byrne, 1990) and using the following equation. 


$$
G_{\max }=\rho v_{s}^{2}
$$

Where $\rho$ is the density of a soil layer and $v$ is the shear wave velocity in that soil layer. Also, $G_{\max }$ can be obtained for a small shear strain amplitude from laboratory tests such as the resonant column test and the bender element test (Kim and Novak, 1981; Kramer, 1996). Empirical equations have been proposed by various researchers to estimate $G_{\text {max }}$ based on basic soil properties such as void ratio, OCR and the effective principal stresses. The value of maximum shear modulus significantly depends upon the OCR and the confining stress level. Also, it increases with increasing OCR and confining stress values (Okur and Ansal, 2007; Jung et al., 2013). Table 2.3 summaries the environmental and loading condition effects on $G_{\max }$ of normally consolidated and slightly over consolidated soils.

\subsubsection{Modulus reduction and Damping curve}

Modulus reduction and damping curves are primary input parameters for a soil dynamic analysis using equivalent liner model. Both curves are expressed as a function of the cyclic shear strain. The modulus reduction curve takes the highest value at a very small strain $\left({ }^{G_{s e c}} / G_{\max }=1\right)$ and degrades with increasing $\gamma_{c}$, while the damping curve starts with a very low value (almost zero at very low $\gamma_{c}$ ) and increases with $\gamma_{c}$. Figure 2.14 shows a general pattern of $G_{s e c} / G_{\max }$ and $\xi$ with $\gamma_{c}$. Vucetic and Dobry (1991) introduced two cyclic threshold shear strains $\left(\gamma_{t}^{e}\right.$ and $\left.\gamma_{t}^{c}\right)$ and divided the strain range into three different zones. In the very small range of shear strain $\left(\gamma_{c}<\gamma_{t}^{e}\right.$, approximately $<$ 0.001 to $0.0001 \%$ ), soil shows a linear stress strain behavior and has the maximum and an almost constant shear modulus, while the damping ratio in this region is very low and 
energy loss is mainly due to friction between particles (Vucetic et al., 1998). The corresponding shear strain at which the shear modulus reduces to $98 \%$ of the maximum shear strain is named as the elastic threshold strain, $\gamma_{t}^{e}$ (Vucetic and Dobry, 1991).

Beyond the elastic threshold shear strain, the soil shows nonlinear recoverable response in the second range $\left(\gamma_{t}^{e}<\gamma_{c}<\gamma_{t}^{c}\right)$. When the shear modulus reduces to nearly $80 \%$ of $G_{\max }$, the strains become partially irrecoverable and the corresponding shear strain is known as the cyclic threshold shear strain $\gamma_{t}^{c}$. Severe changes occur in the $G_{s e c} /_{G_{\max }}$ and $\xi$ values after $\gamma_{t}^{c}$ is reached.

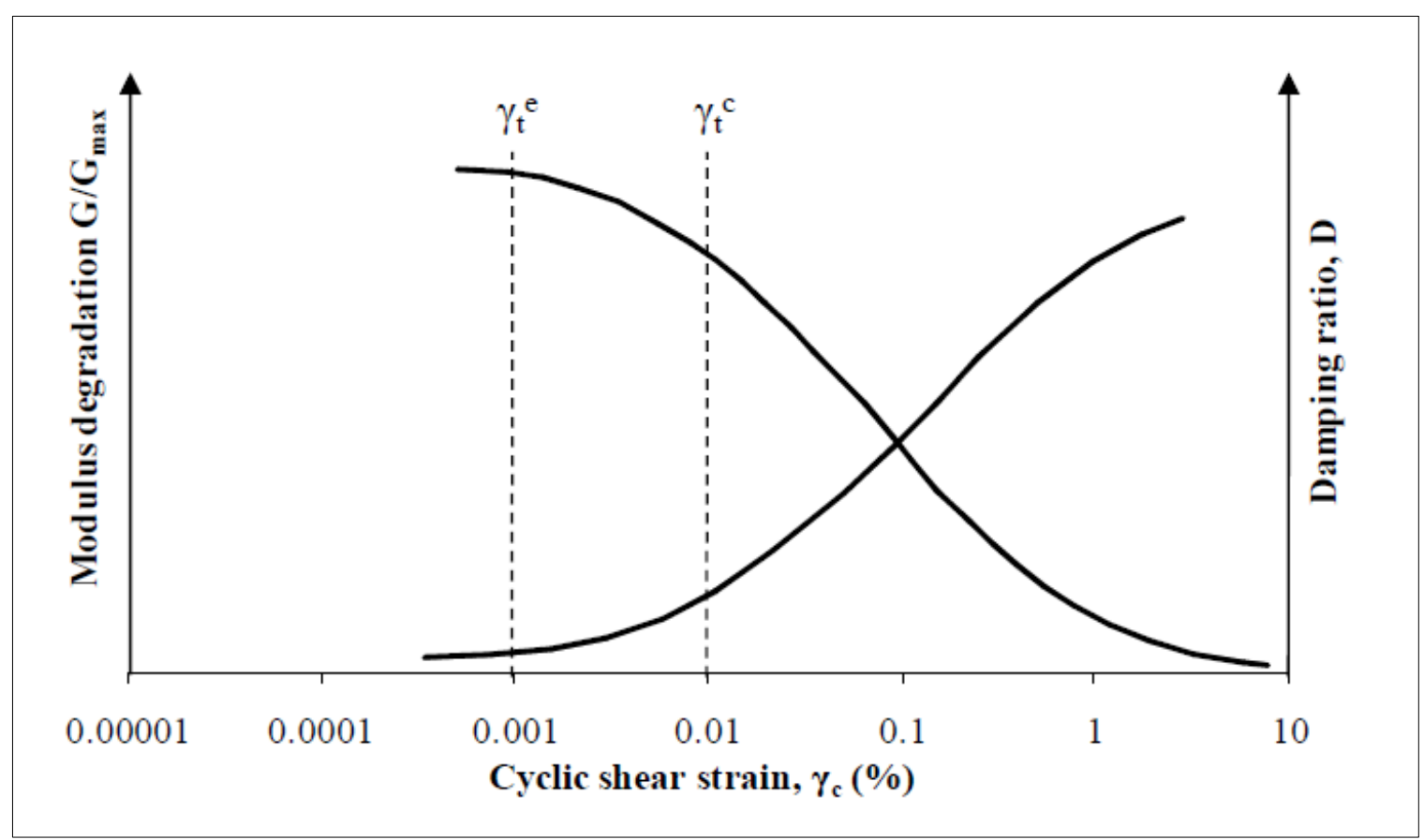

Figure 2-14 Typical Modulus reduction and Damping curve of a soil (after Vucetic and Dobry, 1991)

The modulus reduction and damping curves have been given separately for sands and clays in the literature. Seed and Idriss (1970) proposed $G_{s e c} / G_{\max }$ and $\xi$ curves for sands with three different boundaries (Figures 2.15 and 2.16). Sets of modulus reduction and damping curves for cohesive soils were proposed by Vucetic and Dobry (1991) based 
on the soil plasticity index (Figures 2.17 and 2.18).

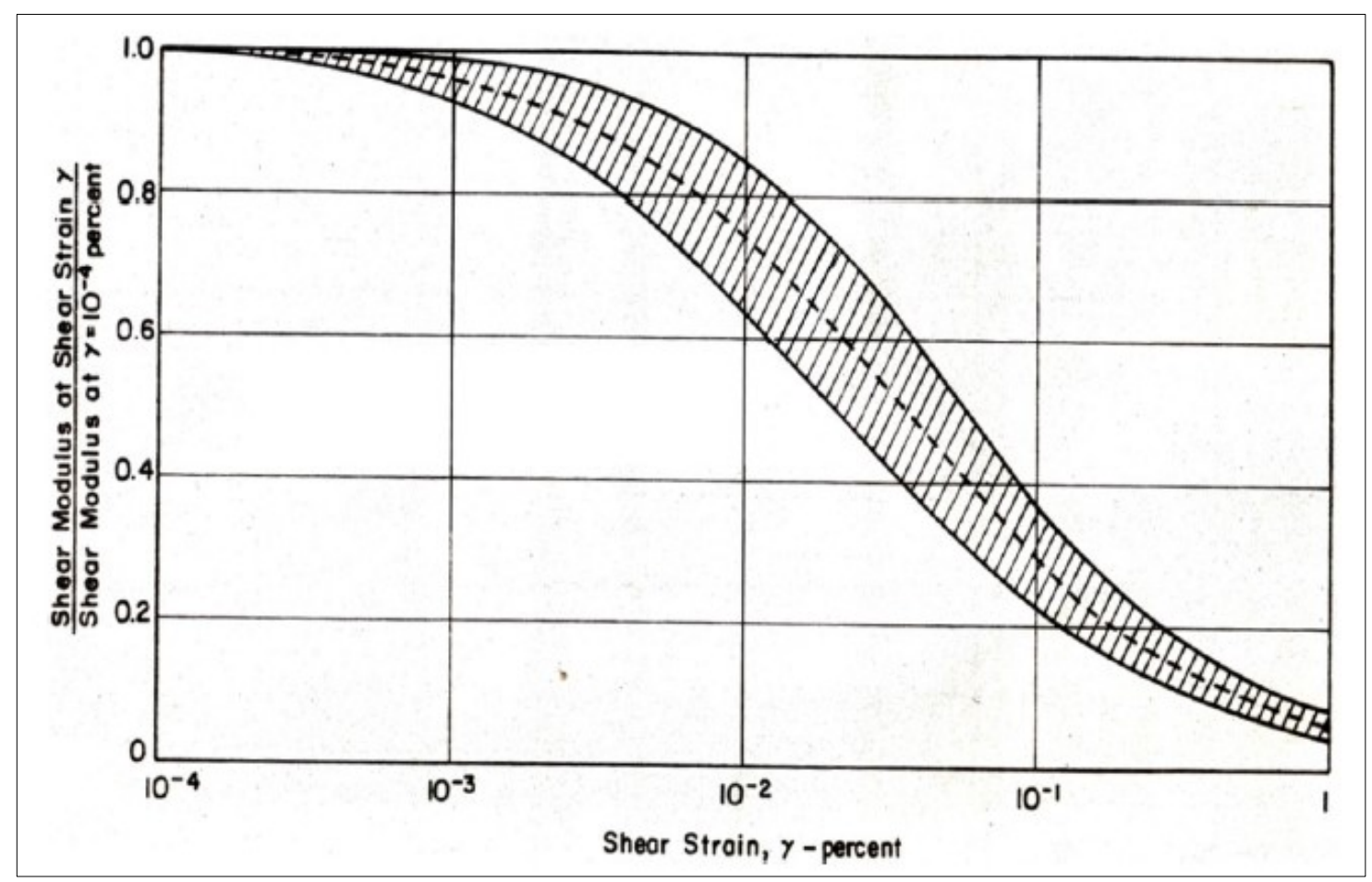

Figure 2-16 Modulus reduction curve of sand (after Seed and Idriss, 1970)

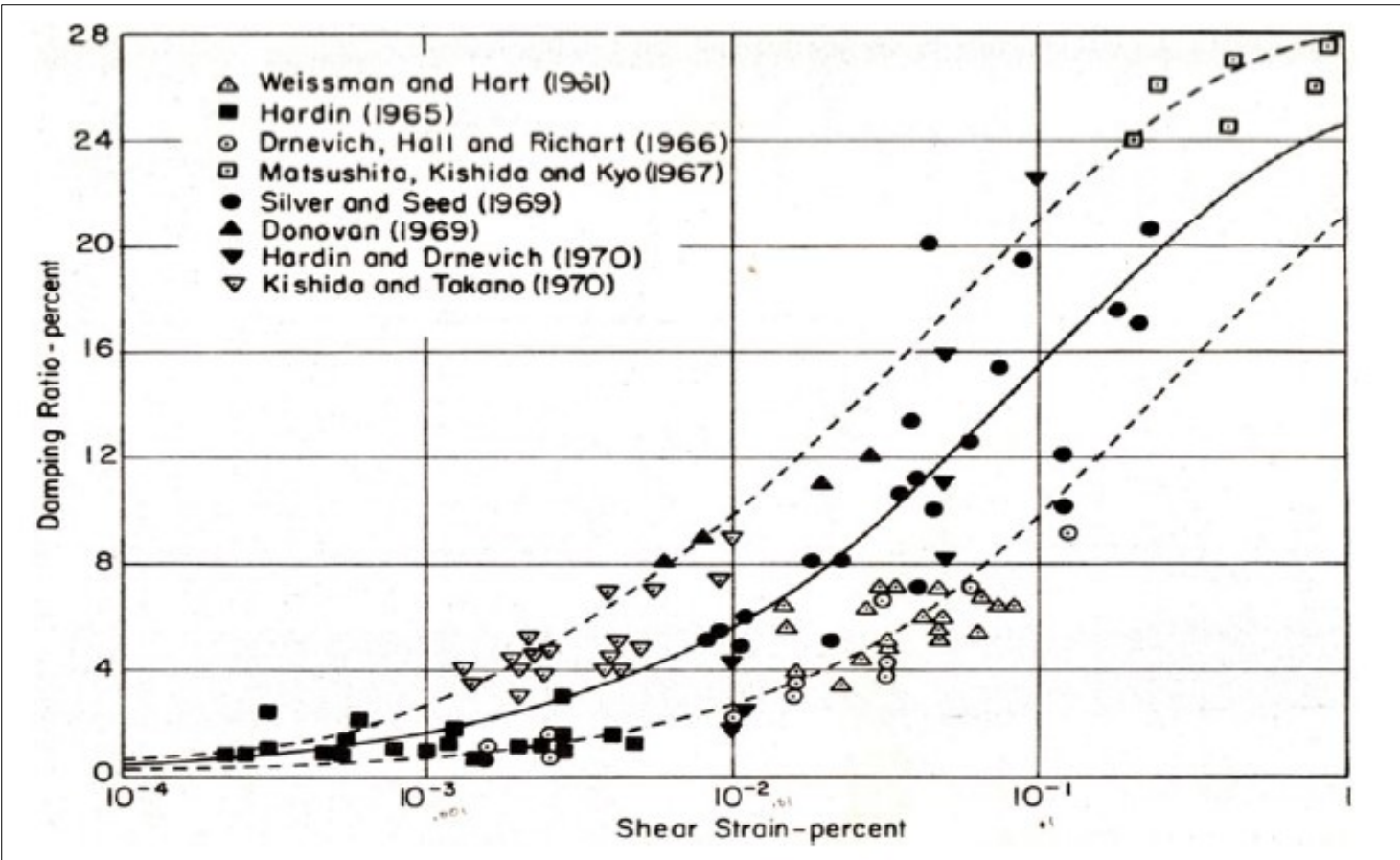

Figure 2-15 Damping curve of sand (after Seed and Idriss (1970) 


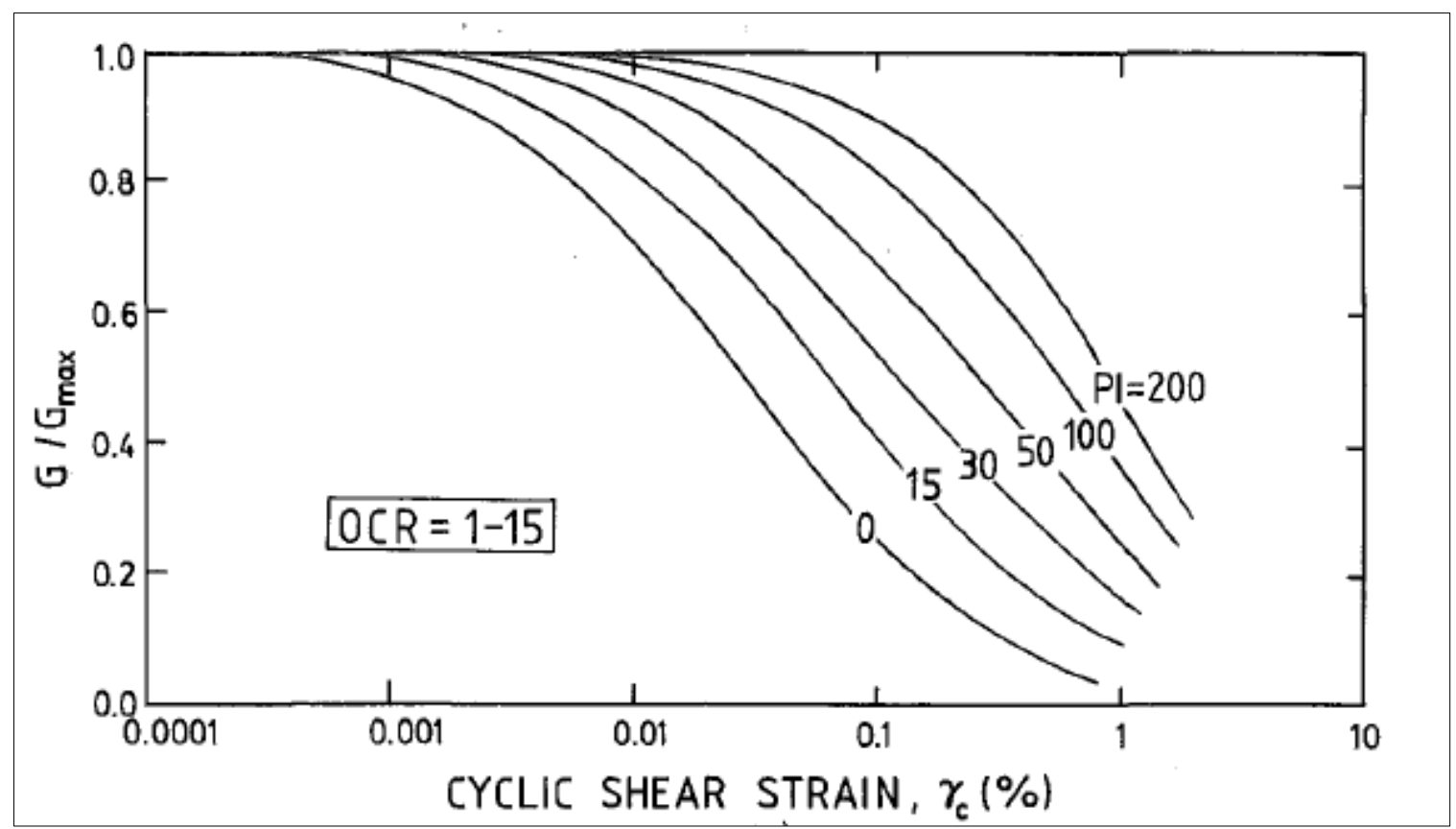

Figure 2-17 Modulus reduction curve of clay (after Vucetic and Dobry, 1991)

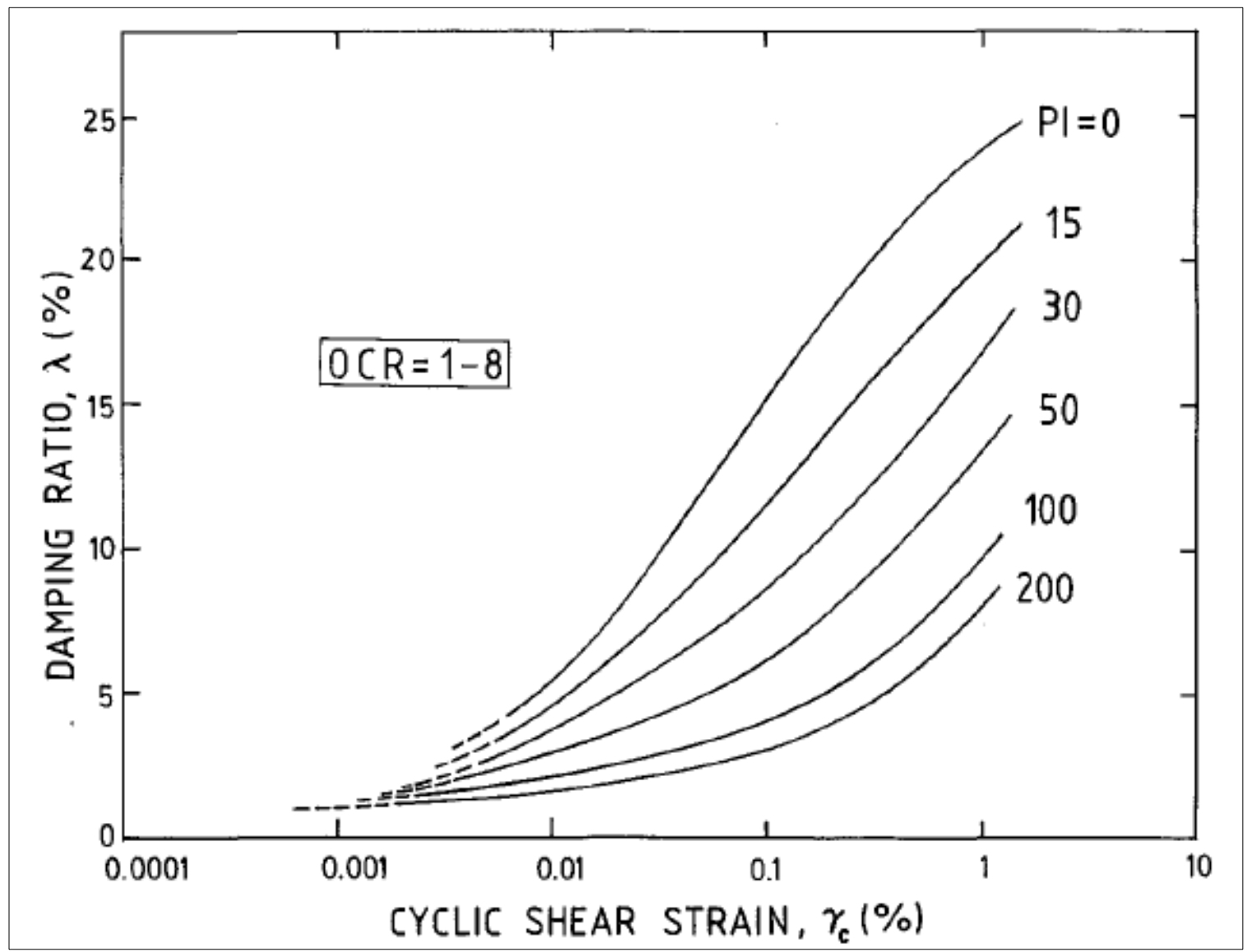

Figure 2-18 Damping curve of clay (after Vucetic and Dobry, 1991) 
Table 2-3 Influence of various factors on Maximum shear modulus, Modulus reduction and damping ratio (modified after Vucetic and Dobry, 1987)

\begin{tabular}{|c|c|c|c|}
\hline Increasing factor & Effect on $G_{\max }$ & Effect on $G_{\text {sec }} /_{G_{\max }}$ & Effect on $\xi$ \\
\hline $\begin{array}{c}\text { Effective } \\
\text { confining } \\
\text { pressure, } \sigma^{\prime}{ }_{m}\end{array}$ & Increase with $\sigma_{m}^{\prime}$ & $\begin{array}{c}\text { Stay constant or } \\
\text { increases with } \sigma_{m}^{\prime}\end{array}$ & $\begin{array}{c}\text { Stay constant or } \\
\text { decreases with } \sigma^{\prime}{ }_{m}\end{array}$ \\
\cline { 3 - 4 } Void ratio, $e$ & Decrease with $e$ & Effect diminishes with increasing PI \\
\hline Geologic age, $t_{g}$ & Increase with $t_{g}$ & May increase with $t_{g}$ & Decrease with $e$ \\
\hline Cementation, $c$ & Increase with $c$ & May increase with $c$ & May decrease with $c$ \\
\hline OCR ratio & Increase with OCR & Not effected & Not effected \\
\hline $\begin{array}{c}\text { Plasticity Index, } \\
\text { PI }\end{array}$ & $\begin{array}{c}\text { Increase with PI in } \\
\text { OC soils }\end{array}$ & Increases with PI & Decrease with PI \\
& $\begin{array}{c}\text { No significant } \\
\text { effect in NC soils }\end{array}$ & & \\
\hline $\begin{array}{c}\text { Loading rate } \\
\text { frequency, } f\end{array}$ & $\begin{array}{c}\text { No effect in non- } \\
\text { plastic soils } \\
\text { In plastic soil, } \\
\text { increases with } f\end{array}$ & No significant effect & No significant effect \\
& & \\
\hline
\end{tabular}

The modulus and damping curves of soils are influenced by many factors such as the effective confining stress, void ratio, geologic age, cementation, over consolidation ratio, plasticity index, strain rate, number of loading cycles, and soil anisotropy. The effect of these parameters is shown in table 2.3. In common practice, modulus reduction and damping curves proposed by Vucetic and Dobry (1991) are widely adopted by geotechnical engineers for clays. However, it is strongly recommended that site specific modulus reduction and damping curves must be used for sensitive clays and cemented sands, as they may deviate from the proposed sets of curves (e.g. Theenathayarl, 2015; Thirugnanasampanther, 2016). 


\section{Experimental Programme}

A detailed experimental programme was carried out to achieve the objectives mentioned in chapter one. Monotonic, cyclic and small strain cyclic tests were conducted on Leda clay, Fraser River sand and Ottawa sand samples using the Carleton University Triaxial device. Also, some improvements were made to the current device to enhance the accuracy of measurements during small stain tests. This Chapter discusses the triaxial device and its functions, modifications made to enhance its performance, the testing method, sample preparation methods, and the details of the conducted test.

\subsection{Triaxial Apparatus}

The triaxial device has been the most widely used apparatus in geotechnical engineering for several decades. It is capable of simulating axisymmetric in-situ soils conditions and is the preferred choice of engineers for evaluating soil strength and stiffness parameters owing to its advantages over the other laboratory devices. Some of the main advantages of using a triaxial device are listed as below.

Testing procedure is simple and straightforward

Control over drainage conditions (Drained, Undrained and Partially drained), and the ability to measure pore water pressure

$>$ Compared to the direct shear device, stress concentration at the ends of the sample is not significant

$>$ Unlike the direct shear device, failure plane of the specimen is not fixed and changes with soil properties

Measurements enable the determination of the true stress/strain state in the soil 
The test typically uses a tall cylindrical specimen of soil with diameter ranging from $38 \mathrm{~mm}$ to $100 \mathrm{~mm}$, and a height to diameter ratio of approximately $2: 1$ to reduce the end restraint and improve stress - strain uniformity in the sample. (Taylor, 1948; Bishop and Green, 1965; Lade, 1982). The specimen is sealed with a rubber membrane and placed into a cell which can be pressurized. The test commonly includes three main stages known as saturation, consolidation and shearing. Table 3.1 explains the functions of primary triaxial components.

Table 3-1 Primary components of a typical triaxial system and its function

\begin{tabular}{|c|c|}
\hline Component & Function \\
\hline Top and bottom pedestal & $\begin{array}{l}\text { Supporting the specimen at correct position and } \\
\text { providing drainage ports }\end{array}$ \\
\hline Rubber membrane and O-rings & $\begin{array}{l}\text { Seal the specimen from cell fluid and maintain } \\
\text { different pressure (cell pressure and pore pressure) }\end{array}$ \\
\hline Porous discs & Allowing drainage through the sample \\
\hline $\begin{array}{l}\text { Back pressure / volume } \\
\text { controller }\end{array}$ & $\begin{array}{l}\text { Apply back or pore pressure to the specimen and } \\
\text { measure volume changes }(\nabla V)\end{array}$ \\
\hline Cell pressure & Apply all around confining pressure to the specimen \\
\hline Load cell & Measure the change in axial load \\
\hline Axial displacement transducer & Measure the change in specimen height \\
\hline $\begin{array}{l}\text { Cell and pore Pressure } \\
\text { transducers }\end{array}$ & $\begin{array}{l}\text { Measure the change in pressure in cell and pore } \\
\text { pressures }\end{array}$ \\
\hline
\end{tabular}


After placing the prepared specimen in the cell, a cell pressure and back pressure are applied on the specimen to improve saturation. After the sample is saturated, the specimen's stress conditions are adjusted to represent the in-situ conditions by consolidating the sample to the target stresses. Thereafter, the sample can be sheared by axial compression or extension. The axial compression test is very common in which the vertical stress applied on the specimen is increased while the cell pressure is kept constant. During triaxial compression, the major principal stress axis coincides with the vertical axis and the minor principal stress axis with the horizontal stress axis.

The triaxial extension tests are generally conducted by decreasing the vertical axial stress while keeping the cell pressure constant. In extension test, the horizontal axis becomes the major principal stress axis and the vertical axis becomes the minor principal stress axis.

Stress conditions in triaxial test can be conveniently represented by using the Mohr's circle. Figure 3.1 shows the isotropically and anisotropically consolidated soil sample's stress state under both compression and extension conditions with the Mohr's circle diagram.

In triaxial tests if/when the axial deviatoric stress direction reverses, a sudden jump occurs in the principal stress direction $(\alpha)$ with a $90^{\circ}$ rotation. Such rotation is not typical in the in-situ conditions, as earthquake loading generally leads to smooth and continuous stress rotation. Furthermore, the triaxial specimens represent an axisymmetric loading condition which is not suitable to represent the plane strain deformation in field. Also, the influence of the intermediate principal stress $\left(\sigma_{2}\right)$ cannot be studied with the triaxial device because it is always equal to either $\left(\sigma_{1}\right)$ or $\left(\sigma_{3}\right)$. However, the 
axisymmetric field conditions can be easily represented by a triaxial device and the failure plane depends upon the material properties. For Mohr-Coulomb material, the failure plane takes an angle of $(45+\emptyset / 2)^{\circ}$.

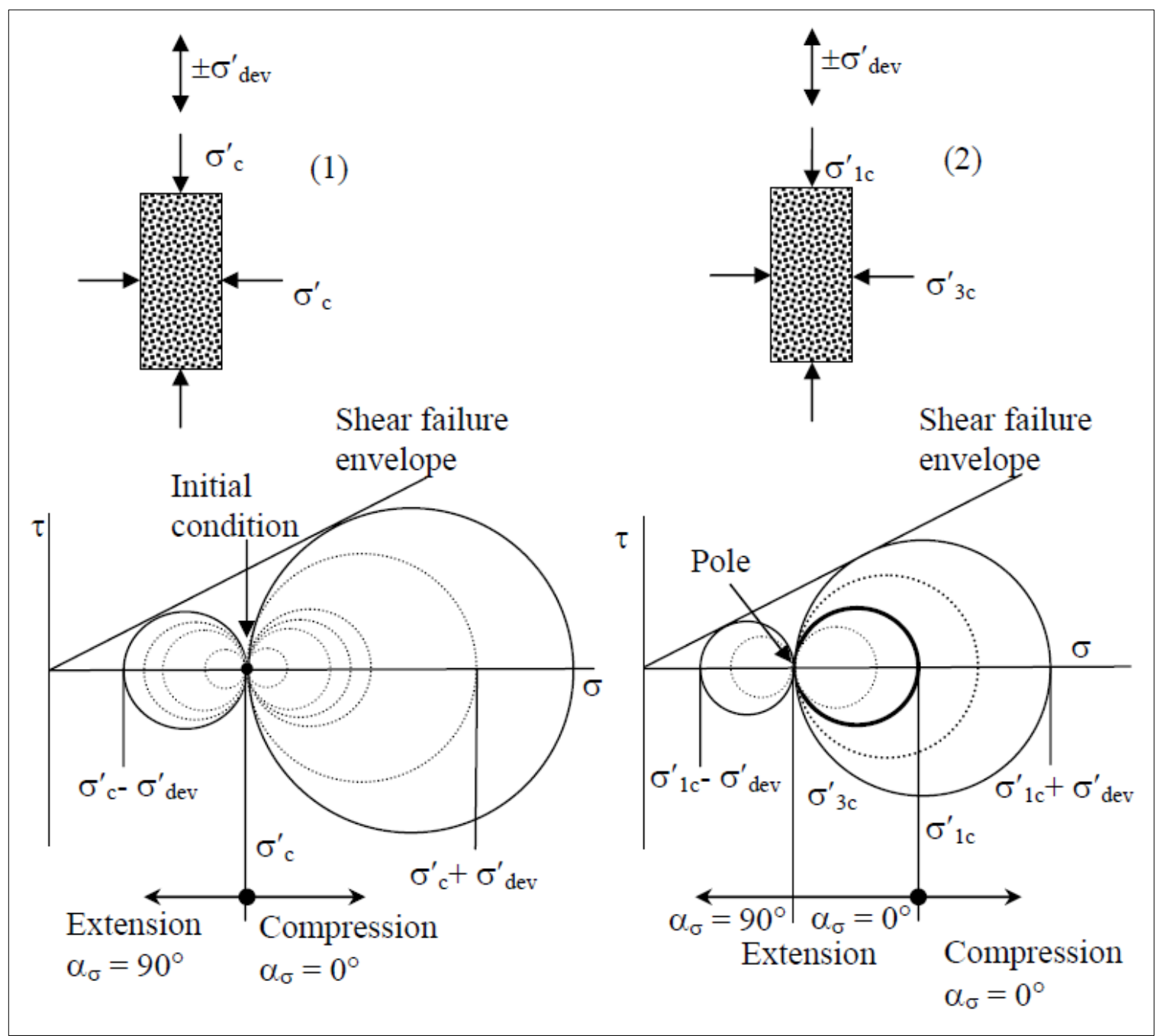

Figure 3-1 Mohr's circle stress representation of (1) isotropically (2) anisotropically consolidated triaxial tests (after Logeswaran, 2010)

\subsection{Carleton triaxial device}

The Carleton University triaxial device is designed to facilitate strain controlled static tests (either in compression or extension) and stress controlled cyclic tests. Specimens of two different sizes were used in this study with two different triaxial cells 
for clayey and sandy soil. All the sand tests were carried out with specimens of height $130 \mathrm{~mm}$ and diameter $63 \mathrm{~mm}$ approximately. The undisturbed clay samples tested were of a relatively smaller size with approximately $72 \mathrm{~mm}$ height and $36 \mathrm{~mm}$ diameter. Two porous stones of diameter $21 \mathrm{~mm}$ were used at the center of the top and bottom pedestal for the sand specimens, and 36mm wide porous stones were used for the clay specimens. Figures 3.2 and 3.3 show a schematic diagram and an actual photograph of the Carleton triaxial device respectively.

Two different load cells with different range capacities (450kg and $225 \mathrm{~kg}$ ) and a precision higher than $0.01 \mathrm{~kg}$ were used to measure the applied vertical load in sand and clay tests respectively. Axial strain was measured by a Linear Variable Displacement Transducer (LVDT) with a range of $25 \mathrm{~mm}$ (and a precision of $10 \mu \mathrm{m}$ ) along with another smaller range LVDT with a range of $\pm 2 \mathrm{~mm}$ (and a resolution of $0.5 \mu \mathrm{m}$ ) was mounted on the device to accurately measure the smaller strain measurements during the modulus and damping tests.

The volume change in the sample was measured by using a Differential Pressure Transducer (DPT), which is capable of measuring low differential pressure range of \pm $3.4 \mathrm{kPa}$. Also, high performance pressure transducers with a resolution of $0.1 \mathrm{kPa}$ and a range of $700 \mathrm{kPa}$ were used to measure the cell and pore water pressures. Standard triaxial cells with low frictional air bleeding seal loading ram along with vacuum grease were used in this study. Stress controlled cyclic loading was applied by using a double acting 'frictionless' air piston where the cyclic pressure is controlled by high performance Electro Pneumatic Pressure Transducer (EPT). The double acting piston is connected with the constant speed drive which applies strain controlled loading. Also, during 
consolidation process, the double acting piston is used to achieve the desired vertical loads (mainly during anisotropic consolidation).

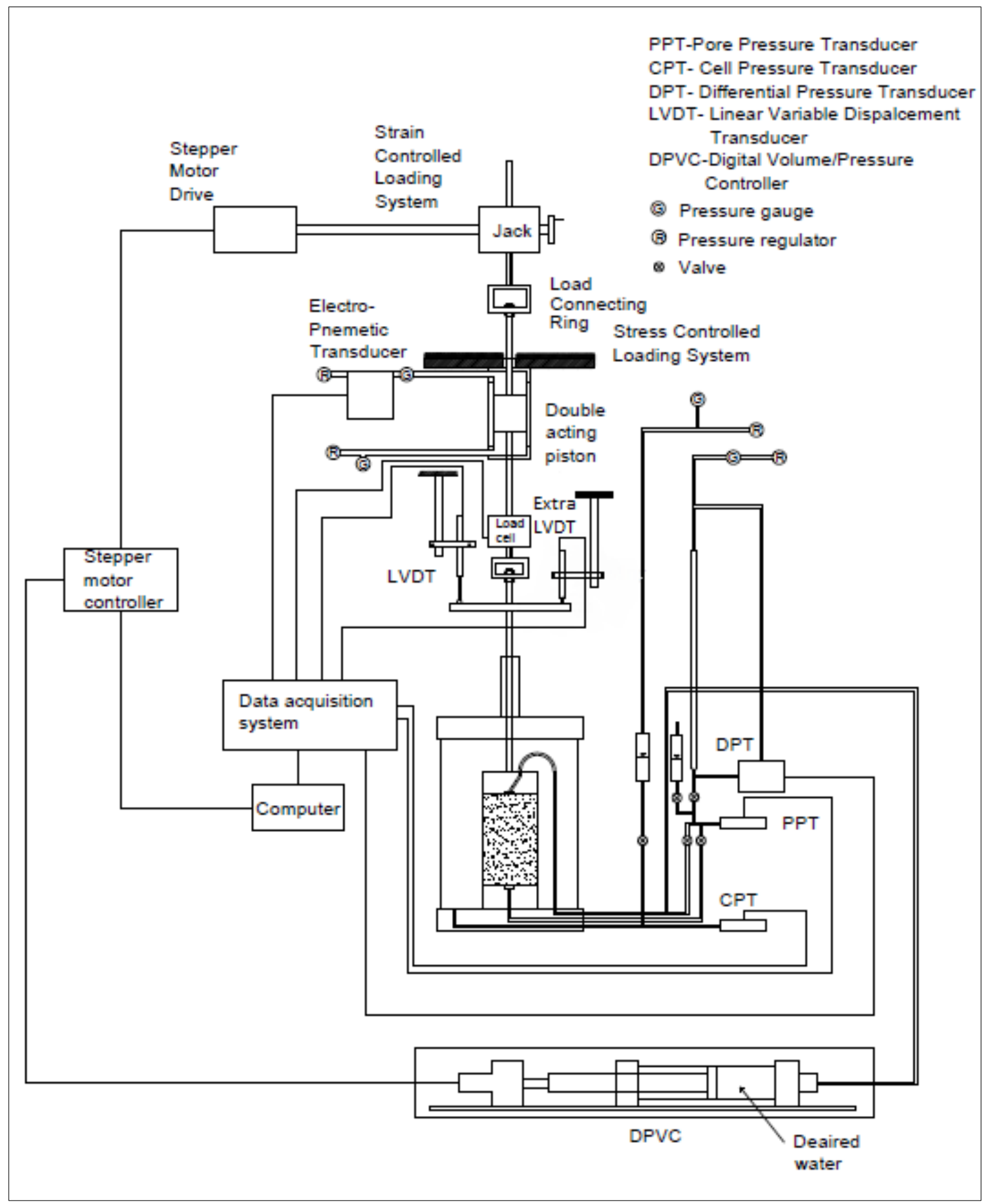

Figure 3-2 Schematic diagram of Carleton triaxial device (modified after Logeswaran, 2005) 


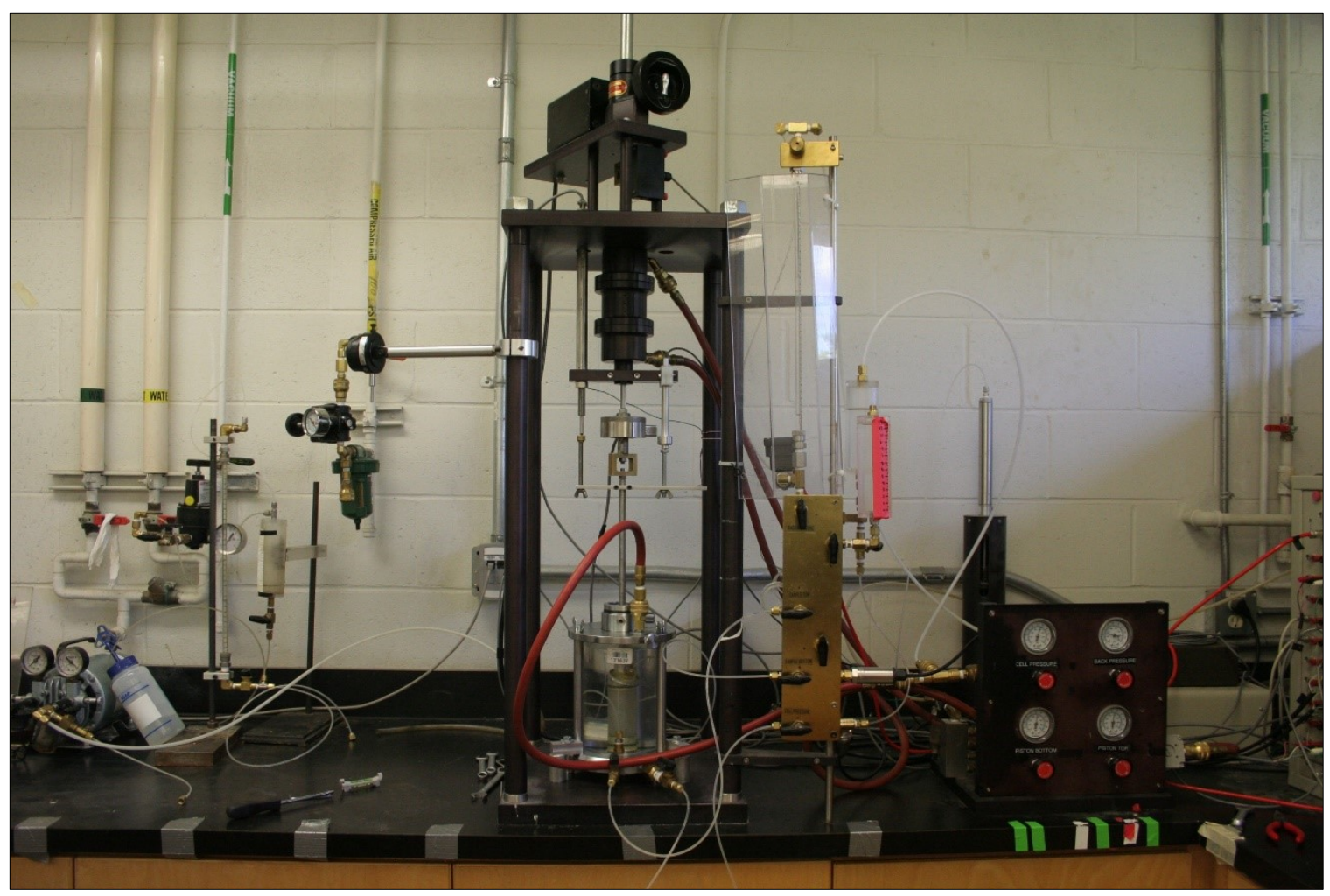

Figure 3-3 Triaxial device at Carleton University

\subsection{Test procedure}

All the LVDTs, load cells, pressure transducers, DPT and EPT were calibrated before starting the test programme. High quality undisturbed Leda clay samples and reconstituted sand samples were carefully prepared and tested in the triaxial device.

\subsubsection{Leda clay sample preparation}

The following steps were adopted in preparing undisturbed clay samples.

$>$ Membrane was flipped back over the split sample-former and little suction was applied to keep the cavity in a uniform cylindrical shape.

Bottom and top pore pressure lines were saturated with de-aired water.

Cell was setup with a dummy sample of known height, porous stones and the 
loading ram. Thereafter, the reference height was noted.

$>$ Undisturbed clay sample slightly larger than the required specimen size was placed in the trimmer and carefully trimmed by a wire saw to form a cylindrical surface (Figure 3.4).

The trimmed sample was then moved to a metal mould and its edges were carefully trimmed to the required height using a wire saw (Figure 3.5). The trimmed clay particles were collected to determine the water content of soil and the weight of final specimen was also measured.

$>$ The sample was covered with membrane and placed on the bottom pedestal with porous stone.

$>$ The loading ram was placed over the sample with the porous stone, and the membrane was flipped back on bottom and top pedestal.

Split former was removed and the sample was sealed with O-rings (Figure 3.5).

About $20 \mathrm{kPa}$ of suction was applied through the bottom pore pressure line while keeping the top pore pressure line connected to de-aired water supply to suck out the trapped air between sample and membrane.

The cell was then filled with de-aired water and sealed carefully before measuring the final height of the sample

Finally, the cell was placed in the triaxial system and pore and cell pressure lines were connected. 


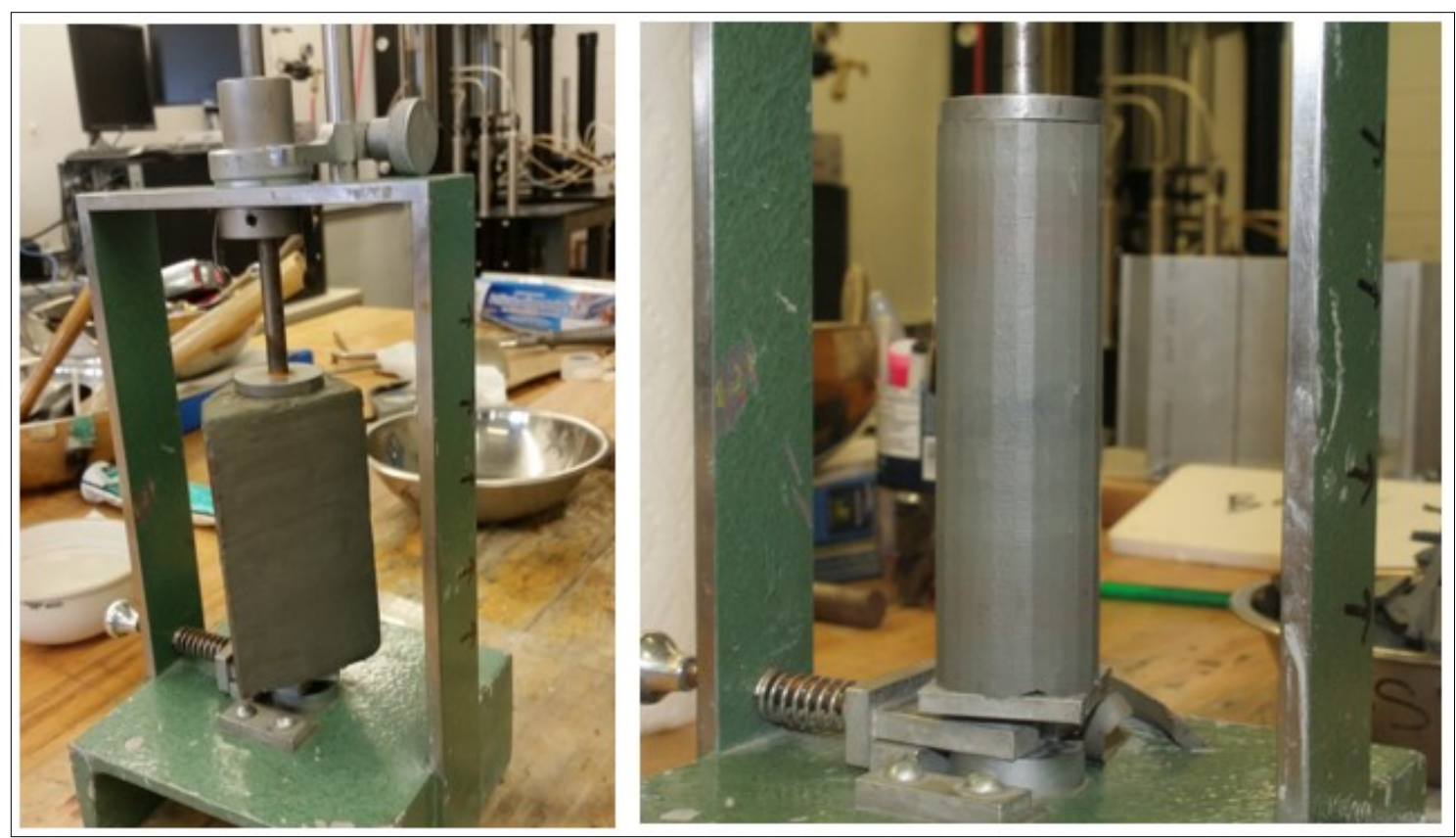

Figure 3-4 A clay sample in the trimmer before and after trimming

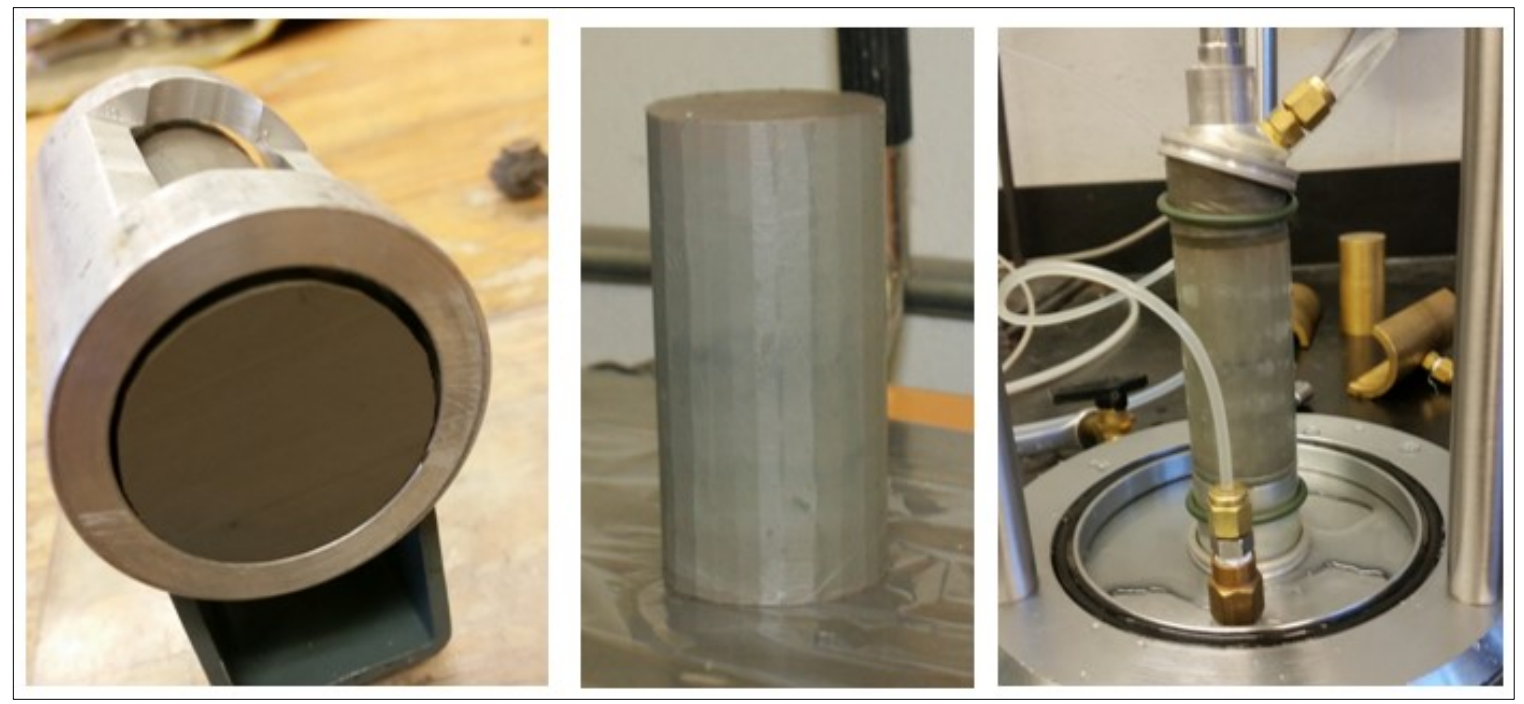

Figure 3-5 Sample in the metal mould, completed trimmed sample and sample after placing on triaxial cell

\subsubsection{Preparation of sand sample}

Undisturbed sandy samples are very difficult and expensive to obtain for laboratory tests. Therefore, samples reconstituted by water pluviation are used in this study. It is one of the most preferred methods to prepare sandy samples because it can 
provide a fabric similar to natural alluvial sands with fully saturated conditions (Vaid at al., 1999). The following procedure was used to prepare the sand specimens.

Firstly, the required amount of sand was boiled to remove the air entrapped between the particles, and then cooled down to the room temperature without air contact. Thereafter, it was pluviated into the membrane lined mould through deaired water (Figure 3.6). A reduced flask tip with a cork was used to control the falling rate of sand. The tip was always kept under water at an essentially constant drop height and slowly rotated to cover the specimen cavity to obtain homogeneous samples with consistent relative density. The excess water and sand at the top of the sample was then removed and leveled by siphoning. Then top cap was placed carefully without disturbing the sample. Higher densities of samples were achieved by tapping beside the base with a soft hammer. Thereafter, the unwanted sand around the top cap was carefully removed and the membrane was flipped on the top cap. It was then sealed with an O-ring. A small suction (around 30kPa) was applied to the sample through the pore pressure line to avoid collapsing after removal of the mould. During this process, the expelled amount of water was measured by collecting it in a graduated burette. The initial volume of the sample before applying the suction was calculated using the mould cavity area and the initial sample height. Then by knowing the expelled volume of water and the current sample height, the current area can be determined accurately. Finally, the cell was filled with deaired water and it was moved to the triaxial system. 


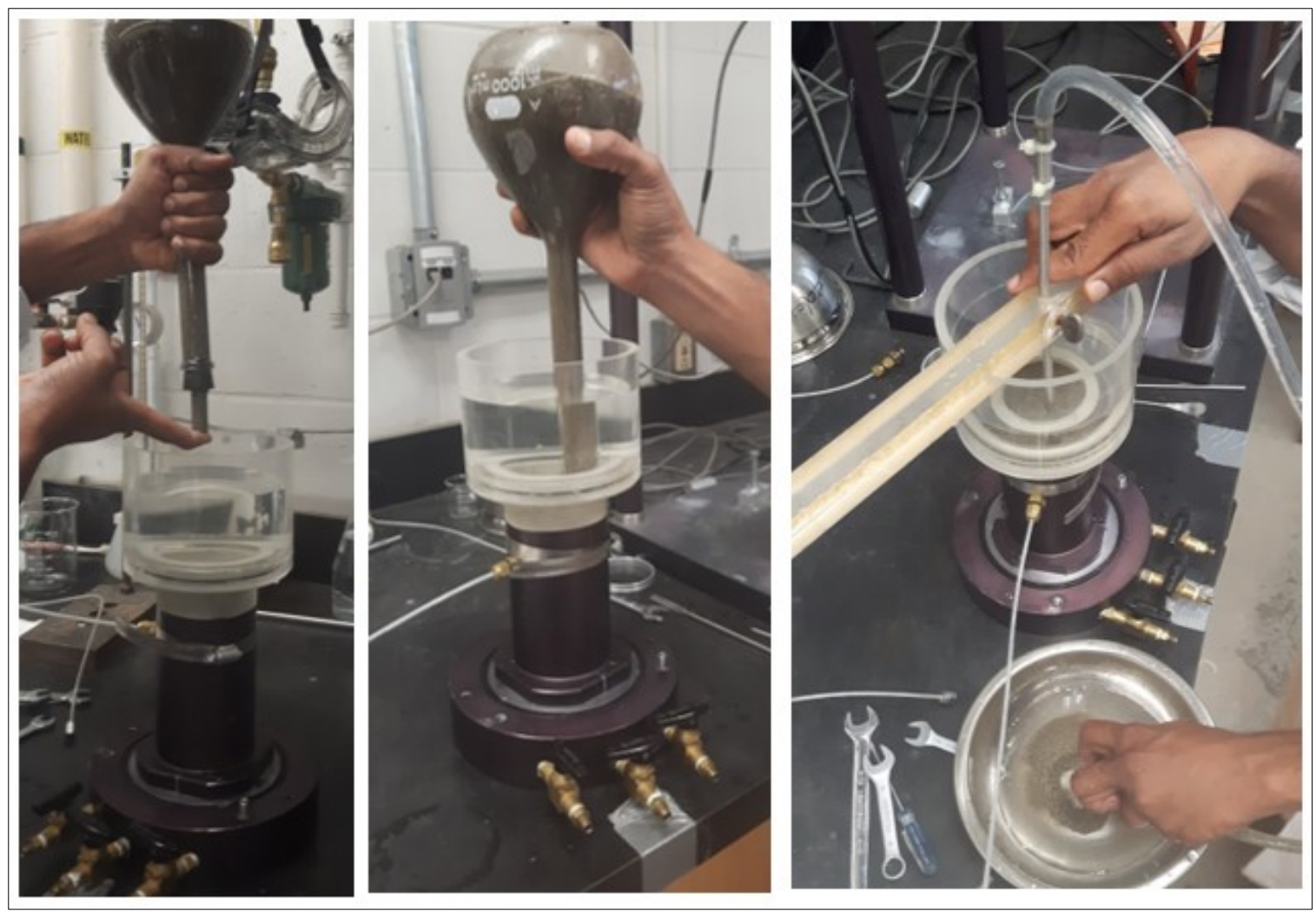

Figure 3-6 Stages of sample preparation using sand

\subsubsection{Saturation}

The degree of saturation of the undisturbed samples is governed by the location of the sample with respect to ground water table and the sampling and setup process. Even though steps were taken to minimize entrapping air during setup, some air will be introduced around the periphery of the sample during the setup process. In these tests, nearly full saturation could be achieved by applying high back pressure to the clay specimen (above 200kPa) for a long duration of time (minimum 12 hours). Saturation of sample for the triaxial test was checked by measuring the Skempton's B-value. For a fully saturated specimen at undrained condition, the change in pore water pressure $(\Delta u)$ should be equal to the change in the cell pressure $\left(\Delta \sigma_{3}\right)$ (Skempton, 1954). The B-value 
can then be defined as $B=\Delta u / \Delta \sigma_{3}$. A minimum value of 0.95 for clay samples and 0.99 for sand samples were confirmed in all tests.

\subsubsection{Consolidation}

After confirming a high B-value, the samples were consolidated to predetermined stress states. The consolidation process was carried out at a constant back pressure, and the cell pressure was increased step by step while keeping the drainage valve open. The consolidation stress steps were increased with a load increment ratio of two $\left(\Delta \sigma / \sigma^{\prime}=2\right)$. For the clay samples, each step of consolidation pressure was applied for an hour and the final pressure was applied for 12 hours to ensure complete dissipation of the pore water pressure. However, for sandy samples, each consolidation pressure stage was maintained for 5 minutes only and the final pressure was applied for 30 minutes. To achieve anisotropic consolidation in sand, the cell pressure and the pressure from double acting pistons were manually adjusted to the target values.

\subsubsection{Shearing phase}

All monotonic, cyclic and multi stage small strain tests were conducted under undrained conditions. Monotonic tests in sand were conducted at an axial strain rate of $12 \%$ per hour, but the rate of axial strain in clay tests was calculated from its consolidation results. Accordingly, all monotonic tests in clay were conducted in an axial strain rate of $1 \%$ per hour which ensures pore-water pressure equalization within the sample during shearing.

The stress controlled cyclic loading was applied through double acting piston and 
all cyclic tests were conducted with a period (T) of 10 secs for both clay and sand samples. Post testing, the wet and dry weights of the sample were recorded to determine the water content, relative density and void ratio.

\subsection{Material tested}

\subsubsection{Leda clay properties}

Monotonic and cyclic tests were conducted on sensitive clay samples collected from Breckenridge and Ourardes-2 sites. Index properties of the tested clays have been determined from laboratory tests (Atterberg, gradation, water content etc.) and from previously reported values by Blanchette (2014), Theenathayarl (2015) and Thirugnanasampanther (2016) for the same material.

The natural water content and plasticity index of Breckenridge clay is quite higher than Outardes-2 clay. Atterberg test results are summarized in table 3.2. The results of hydrometer and sieve analysis have been shown in Figure 3.7. All the Breckenridge particles were finer than $75 \mu \mathrm{m}$ and $72 \%$ were lesser than clay size particles. But only about $27 \%$ of Outardes- 2 particles were smaller than clay size.

Table 3-2 Atterberg limits of Leda clay

\begin{tabular}{|l|l|l|l|l|l|l|}
\hline Bore Hole & $\begin{array}{l}\text { Depth } \\
(\mathrm{m})\end{array}$ & $\begin{array}{l}\text { Natural water } \\
\text { content (W) } \\
(\%)\end{array}$ & $\begin{array}{l}\text { Liquid } \\
\text { Limit (LL) } \\
/(\%)\end{array}$ & $\begin{array}{l}\text { Plastic } \\
\text { Limit (PL) } \\
/(\%)\end{array}$ & $\begin{array}{l}\text { Plasticity } \\
\text { Index } \\
(\mathrm{PI})\end{array}$ & $\begin{array}{l}\text { Liquidity } \\
\text { Index } \\
(\mathrm{LI})\end{array}$ \\
\hline $\begin{array}{l}\text { BRK-02- } \\
\text { TO19 }\end{array}$ & 27.8 & 71.8 & 60.8 & 27.7 & 33.1 & 1.3 \\
\hline $\begin{array}{l}\text { BRK-02- } \\
\text { TO20 }\end{array}$ & 27.7 & 73.1 & 58.5 & 26.4 & 32.1 & 1.5 \\
\hline $\begin{array}{l}\text { F-03-13, } \\
\text { Outardes-2 }\end{array}$ & 11 & 31.2 & 29.5 & 20.3 & 9.2 & 1.2 \\
\hline
\end{tabular}




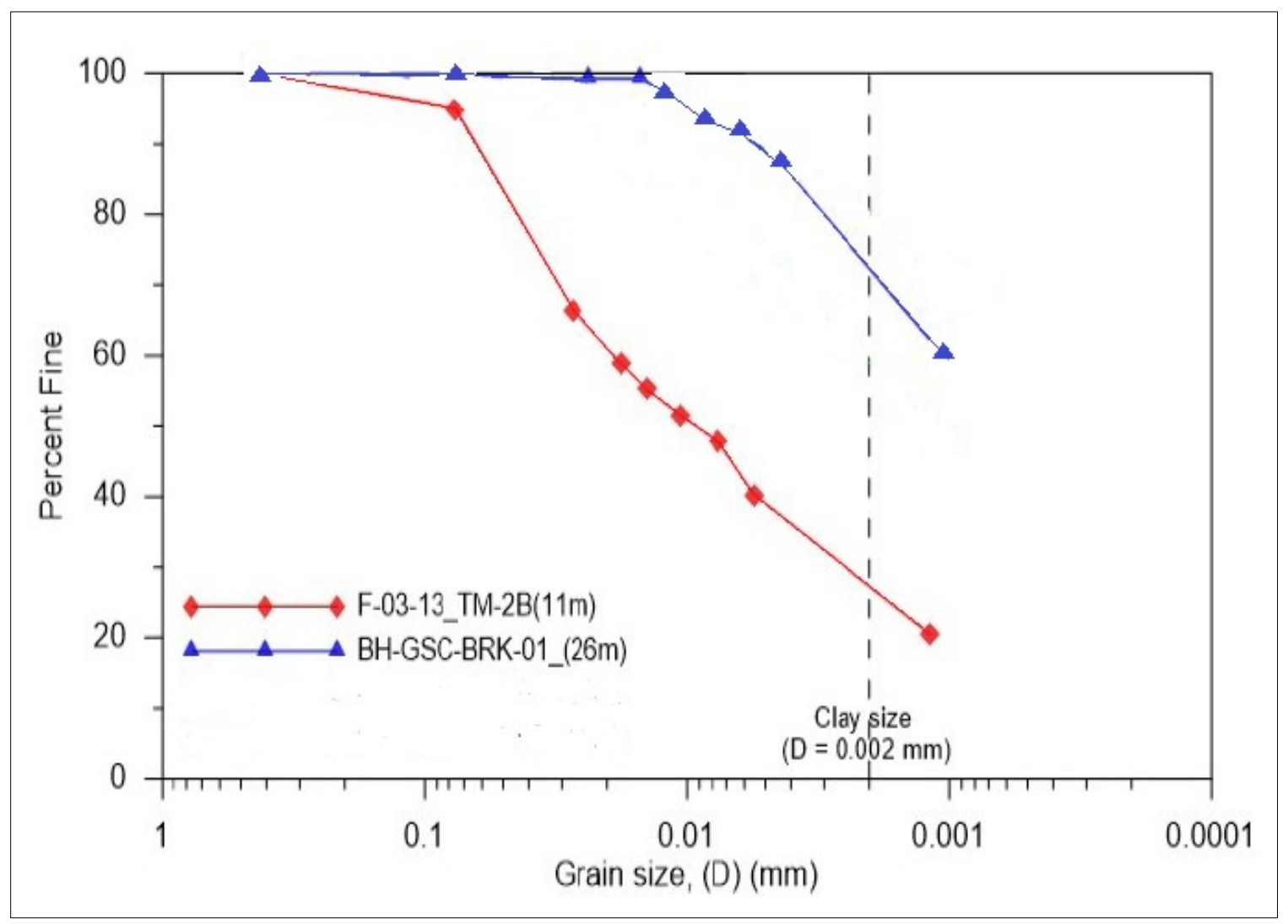

Figure 3-7 Particle size distribution of Leda clays (modified after Thirugnanasampanther, 2016)

\subsubsection{Sand properties}

Monotonic and cyclic sand tests were conducted with two different sands, i.e., Fraser River sand and Ottawa sand. The Fraser River sand was dredged near Abbotsford in British Columbia, and the fine particles were removed by wet-sieving through $0.075 \mathrm{~mm}$ sieve. The other sand used in this research study is the commercially available Ottawa sand (ASTM designation C778) obtained from Illinois. It is a poorly graded sand with sub-rounded quartz particles. Figure 3.8 and 3.9 shows the particle size distribution of the sands, and table 3.3 lists other relevant properties determined according to ASTM standards. 
Table 3-3 Material properties of Fraser River sand and Ottawa sand

\begin{tabular}{|l|c|c|}
\hline Material Property & FRS & Ottawa sand \\
\hline Maximum void ratio, $e_{\text {max }}$ & 0.806 & 0.723 \\
\hline Minimum void ratio, $e_{\min }$ & 0.509 & 0.478 \\
\hline Average particle size, $D_{50}$ & $0.28 \mathrm{~mm}$ & $0.43 \mathrm{~mm}$ \\
\hline Uniformity coefficient, $c_{u}$ & 2.92 & 1.93 \\
\hline Coefficient of curvature, $c_{c}$ & 1.27 & 2.66 \\
\hline Specific gravity, $G_{s}$ & 2.67 & \\
\hline
\end{tabular}




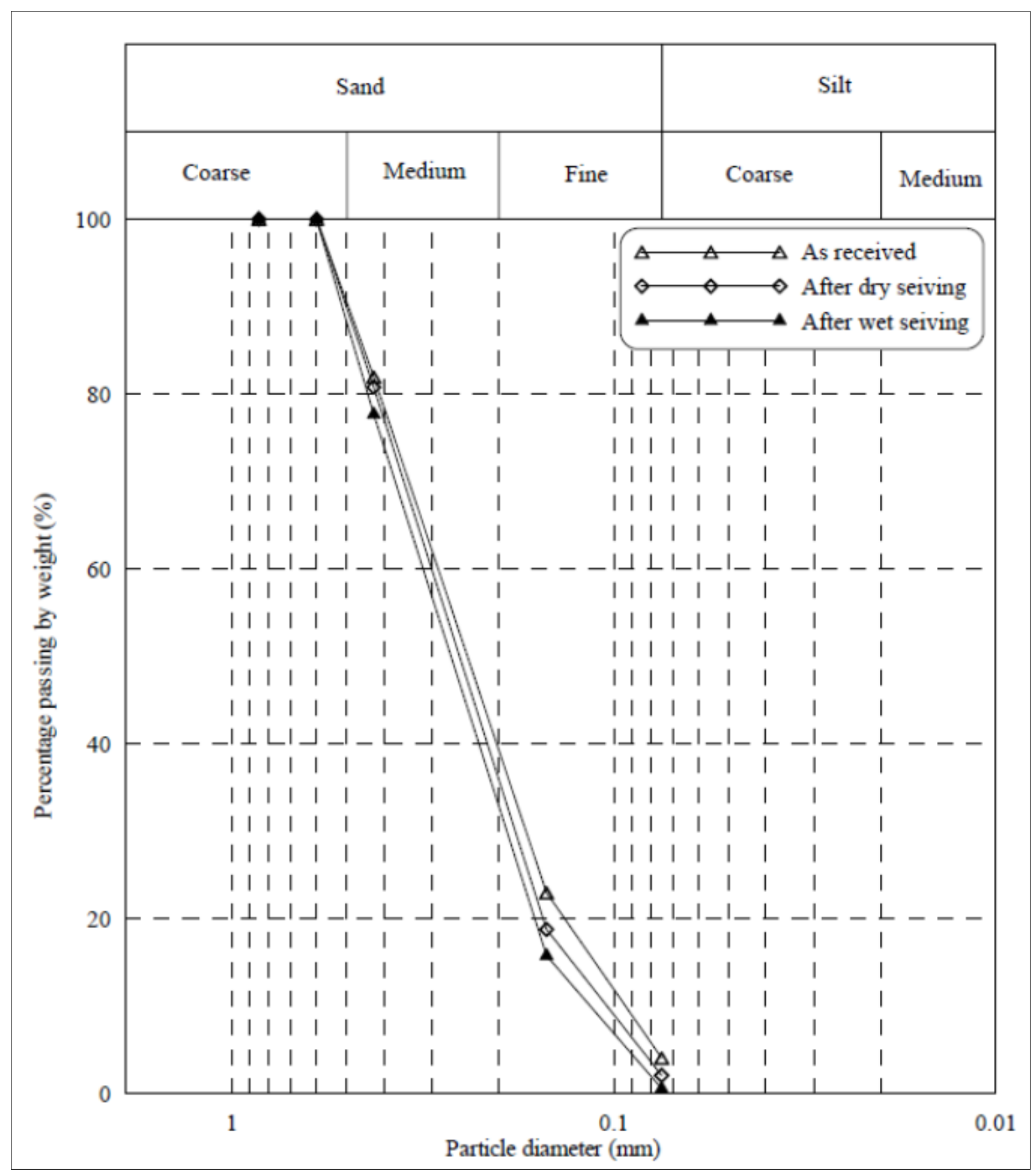

Figure 3-8 Grain size distribution of Fraser River sand (after Logeswaran, 2010) 


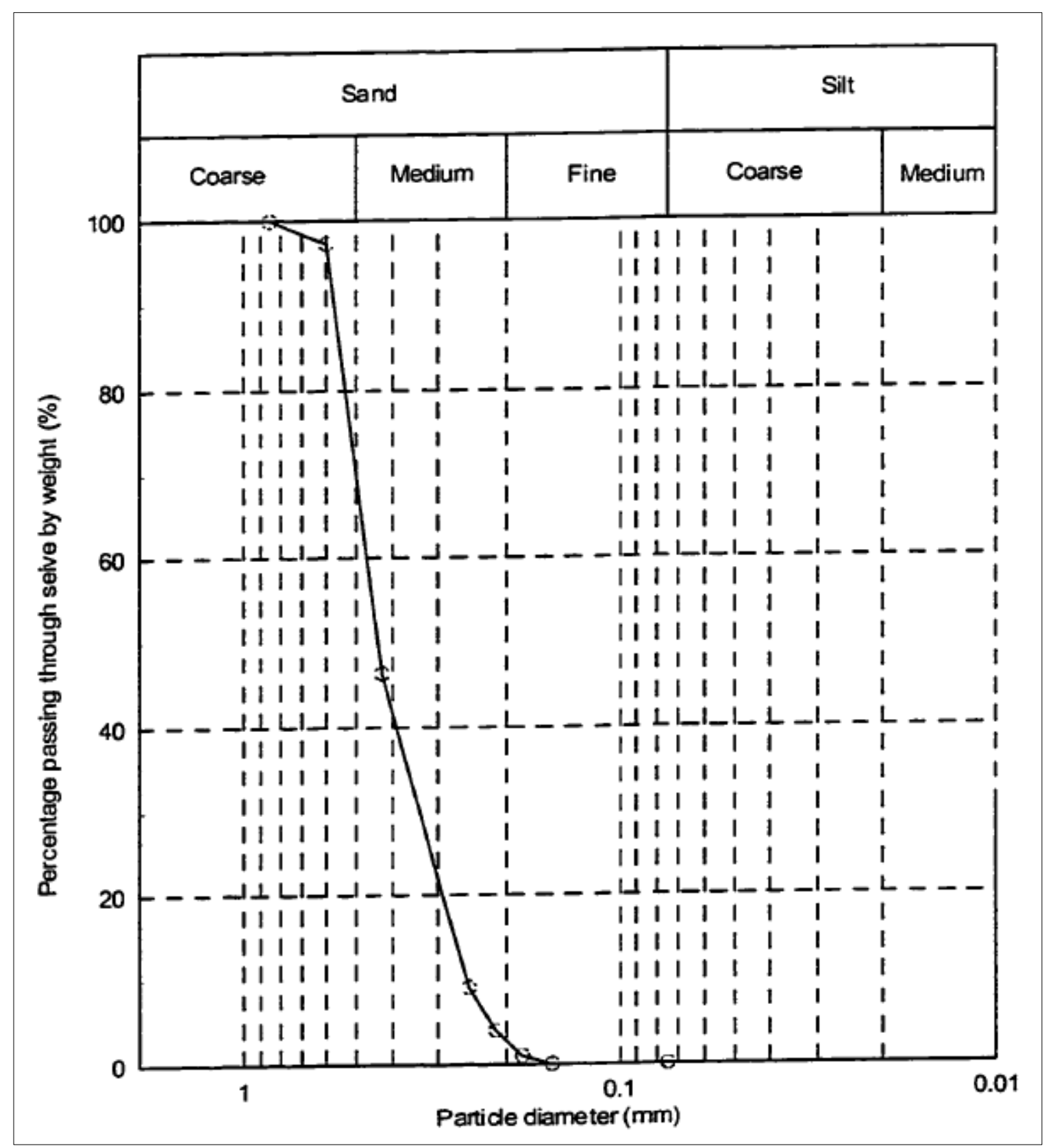

Figure 3-9 Grain size distribution of Ottawa sand (after Logeswaran, 2005)

\subsection{Corrections for membrane strength}

A part of the axial and confining loads applied to a triaxial soil specimen is carried by the flexible rubber membrane encasing the specimen. The forces carried by a membrane depends on how stretched it is from its original position. These membrane 
forces could produce significant errors in the stresses calculated while testing soft sediments at low confining pressure, and also while conducting undrained tests on loose sands (Kuerbis and Vaid, 1990). Therefore, membrane strength correction is very important to avoid erroneous assessment in triaxial tests.

The method proposed by Kuerbis and Vaid (1990) is used in this study to correct the membrane strength affects. They derived the following two equations to correct the axial and radial stresses, from elastic thin cylindrical shell compression theory.

$$
\begin{gathered}
\sigma_{a m}^{\prime}=\sigma_{a}^{\prime}-\frac{4 E_{M} t_{0}\left(2+\epsilon_{v}+\epsilon_{M a}\right)\left(3 \epsilon_{M a}+\epsilon_{v}\right)}{3 D_{0}\left(2-\epsilon_{v}+\epsilon_{M a}\right)} \\
\sigma_{r m}^{\prime}=\sigma_{r}^{\prime}-\frac{4 E_{M} t_{0}\left(2+\epsilon_{v}+\epsilon_{M a}\right) \epsilon_{v}}{3 D_{0}\left(2-\epsilon_{v}+\epsilon_{M a}\right)}
\end{gathered}
$$

Where $\sigma_{a m}^{\prime}$ is the effective axial stress on the specimen corrected for membrane stresses, $\sigma_{r m}^{\prime}$ is the effective radial stress on the specimen corrected for membrane stresses, $\sigma_{a}^{\prime}$ and $\sigma_{r m}^{\prime}$ are the measured axial and radial stresses on the specimen, $E_{M}$ is the Young's modulus of membrane rubber, $t_{0}$ and $D_{0}$ are the initial unstretched thickness and diameter of the membrane, $\epsilon_{v}$ is the volumetric strain of the cylindrical membrane cavity, and $\epsilon_{M a}$ is the axial strain in the rubber membrane. The Young's modulus of rubber membrane was determined in the laboratory by the technique described by Bishop and Henkel (1962) and Figure 3.10 shows the prepared setup. 


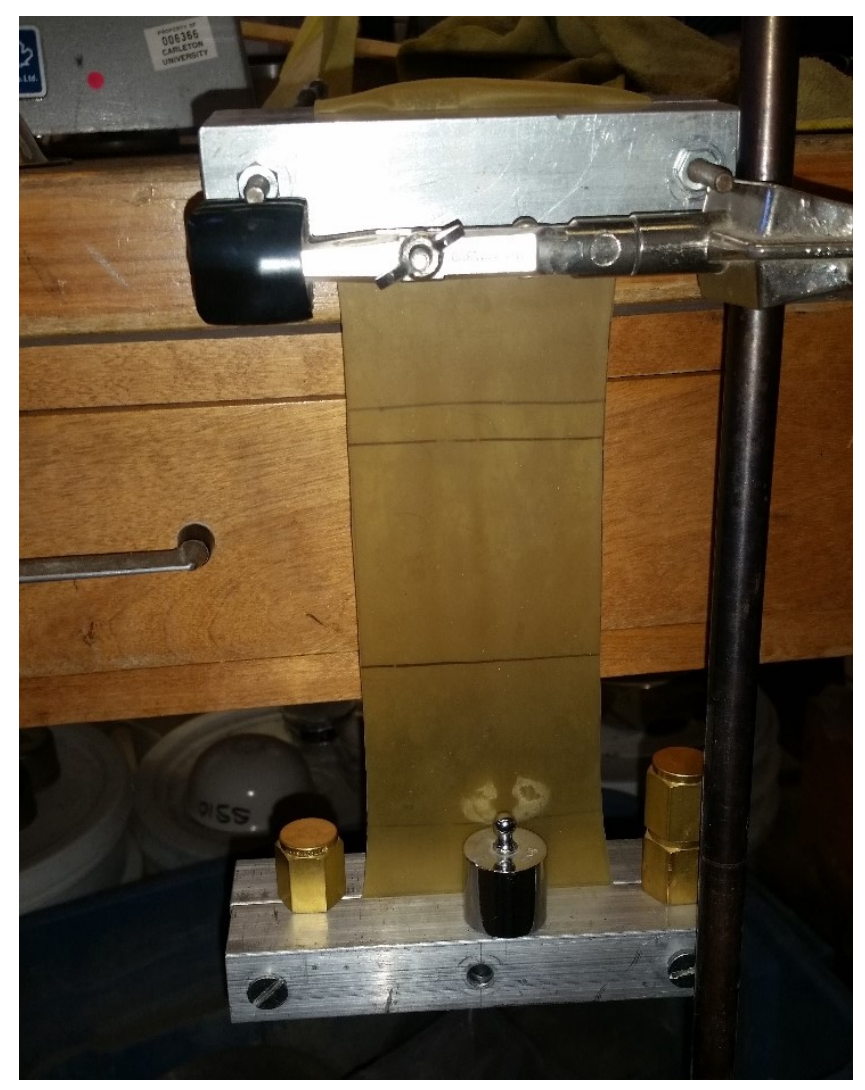

Figure 3-10 Laboratory setup to determine Young's modulus of membrane

\subsection{Test programme}

Undrained monotonic compression triaxial tests were carried out on Leda clay samples at in-situ consolidation pressure and high stress levels, to evaluate the undrained strength behavior. All monotonic tests were conducted on isotropically consolidated samples. Stress controlled undrained cyclic tests were conducted on clay samples, mostly at in-situ stress levels to study the liquefaction potential of sensitive Leda clay. Also stress controlled, small strain cyclic tests were conducted on Leda clay samples at different consolidation pressures to obtain site specific modulus reduction and damping curves. Monotonic cyclic and small strains tests conducted on Leda clay are listed in tables 3.4, 3.5 and 3.6 respectively. In addition, stress controlled, small strain cyclic tests 
were carried out on Fraser River sand and Ottawa sand on isotropically and anisotropically consolidated samples to establish modulus reduction and damping curves, and to study the effect of consolidation stress ratio, $K_{c}$. The details of the sand tests are presented in table 3.7 .

Table 3-4 Details of monotonic test on Leda clays

\begin{tabular}{|c|c|c|c|c|}
\hline Site & Test ID & Bore hole Details & $\begin{array}{l}\text { Consolidation } \\
\text { Pressure } \\
\text { (kPa) }\end{array}$ & $\begin{array}{l}\text { Peak } \\
\text { Su } \\
\text { (kPa) }\end{array}$ \\
\hline $\begin{array}{l}\text { Breckenridge } \\
(\mathrm{NC})\end{array}$ & MON-01 & BH-GSC-BRK-02, TO-19, $27.85 \mathrm{~m}$ & 200 & 98.1 \\
\hline $\begin{array}{l}\text { Breckenridge } \\
(\mathrm{NC})\end{array}$ & MON-02 & BH-GSC-BRK-02, TO-20, 27.73m & 200 & 125.3 \\
\hline $\begin{array}{l}\text { Breckenridge } \\
(\mathrm{NC})\end{array}$ & MON-03 & BH-GSC-BRK-02, TO-17, $21.56 \mathrm{~m}$ & 150 & 76.0 \\
\hline $\begin{array}{l}\text { Breckenridge } \\
(\mathrm{NC})\end{array}$ & MON-04 & $\begin{array}{l}\text { BH-GSC-BRK-02, TO-15-1, } \\
21.74 \mathrm{~m}\end{array}$ & 400 & 102.5 \\
\hline $\begin{array}{l}\text { Breckenridge } \\
\text { (OC) }\end{array}$ & MON-05 & $\begin{array}{l}\text { BH-GSC-BRK-02, TO-15-3, } \\
21.74 \mathrm{~m}\end{array}$ & 100 & 63.5 \\
\hline $\begin{array}{l}\text { Breckenridge } \\
(\mathrm{OC})\end{array}$ & MON-06 & $\begin{array}{l}\text { BH-GSC-BRK-02, TO-15-2, } \\
21.74 \mathrm{~m}\end{array}$ & 50 & 48.2 \\
\hline $\begin{array}{l}\text { Outardes }-2 \\
\text { (OC) }\end{array}$ & MON-07 & F-03-13, TM-2C, $11.06 \mathrm{~m}$ & 131 & 139.2 \\
\hline
\end{tabular}


Table 3-5 Details of cyclic tests on Leda clays

\begin{tabular}{|c|c|c|c|c|c|c|c|c|}
\hline Site & Test ID & Borehole & $\begin{array}{l}\text { Block sample } \\
\text { number }\end{array}$ & Depth (m) & $\begin{array}{l}\text { Consolidation } \\
\text { Pressure }(\mathrm{kPa})\end{array}$ & $\begin{array}{l}\text { Cyclic } \\
\text { deviatoric } \\
\text { stress }(\mathrm{kPa})\end{array}$ & CSR & $\begin{array}{l}\text { Number of } \\
\text { cycles }\end{array}$ \\
\hline \multirow{2}{*}{$\begin{array}{l}\text { Breckenridge } \\
(\mathrm{NC})\end{array}$} & CYC-01 & \multirow{2}{*}{$\begin{array}{l}\text { BH-GSC-BRK- } \\
02\end{array}$} & \multirow[t]{2}{*}{ TO-19 } & \multirow[t]{2}{*}{27.9} & \multirow[t]{2}{*}{200} & 148.3 & 0.372 & 18 \\
\hline & CYC-02 & & & & & 133 & 0.333 & 77 \\
\hline \multirow{3}{*}{$\begin{array}{l}\text { Breckenridge } \\
(\mathrm{NC})\end{array}$} & CYC-03 & \multirow[t]{3}{*}{ BH-GSC-BRK- } & \multirow[t]{3}{*}{ TO-20 } & \multirow[t]{3}{*}{27.7} & \multirow[t]{3}{*}{200} & 168.9 & 0.424 & 55 \\
\hline & CYC-04 & & & & & 184.3 & 0.462 & 19 \\
\hline & CYC-05 & & & & & 207.5 & 0.521 & 5 \\
\hline \multirow{3}{*}{$\begin{array}{l}\text { Breckenridge } \\
\text { (NC) }\end{array}$} & CYC-06 & \multirow[t]{3}{*}{ BH-GSC-BRK- } & \multirow[t]{3}{*}{ TO-17 } & \multirow[t]{3}{*}{21.6} & \multirow[t]{3}{*}{150} & 123.9 & 0.412 & 11 \\
\hline & CYC-07 & & & & & 109.4 & 0.366 & 87 \\
\hline & CYC-08 & & & & & 133.9 & 0.448 & 8 \\
\hline \multirow{3}{*}{$\begin{array}{l}\text { Outardes }-2 \\
(\mathrm{OC})\end{array}$} & CYC-09 & \multirow[t]{3}{*}{ F-03-13 } & \multirow[t]{3}{*}{ TM-2C } & \multirow[t]{3}{*}{11.1} & \multirow[t]{3}{*}{131} & 129 & 0.492 & 39 \\
\hline & CYC-10 & & & & & 141.2 & 0.536 & 17 \\
\hline & CYC-11 & & & & & 158.3 & 0.603 & 10 \\
\hline
\end{tabular}


Table 3-6 Details of stress controlled small strain tests on Leda clay

\begin{tabular}{|c|c|c|c|c|c|}
\hline Site & Test ID & Borehole & $\begin{array}{l}\text { Block sample } \\
\text { number }\end{array}$ & Depth (m) & $\begin{array}{l}\text { Consolidation } \\
\text { Pressure }(\mathrm{kPa})\end{array}$ \\
\hline Breckenridge (Slightly OC) & M\&D-1 & BH-GSC-BRK-02 & TO-24-1 & 12.7 & 100 \\
\hline Breckenridge (NC) & M\&D-2 & & & & 200 \\
\hline Breckenridge (NC) & M\&D-3 & & & & 400 \\
\hline Breckenridge (NC) & M\&D-4 & BH-GSC-BRK-02 & TO-24-2 & 12.7 & 400 \\
\hline Breckenridge (OC) & M\&D-5 & & & & 200 \\
\hline Breckenridge (OC) & M\&D-6 & & & & 100 \\
\hline Breckenridge (OC) & M\&D-7 & & & & 50 \\
\hline Outardes 2 (OC) & M\&D-8 & F-03-13 & TM-2C & 11.1 & 100 \\
\hline Outardes 2 (OC) & M\&D-9 & & & & 200 \\
\hline Outardes 2 (OC) & M\&D-10 & & & & 400 \\
\hline Outardes 2 (OC) & M\&D-11 & & & & 200 \\
\hline
\end{tabular}


Table 3-7 Details of stress controlled small strain tests on sands

\begin{tabular}{|c|c|c|c|c|c|}
\hline \multirow[t]{2}{*}{ Site } & \multirow[t]{2}{*}{ Test ID } & \multicolumn{2}{|c|}{ Consolidation pressure } & \multirow[t]{2}{*}{ Density } & \multirow{2}{*}{$\begin{array}{c}\text { Consolidation } \\
\text { Stress ratio }\left(k_{c}\right) \\
\sigma_{v}^{\prime} / \sigma_{h}^{\prime}\end{array}$} \\
\hline & & $\sigma_{v}^{\prime}(\mathrm{kPa})$ & $\sigma_{h}^{\prime}(\mathrm{kPa})$ & & \\
\hline \multirow{6}{*}{$\begin{array}{l}\text { Fraser river } \\
\text { sand }\end{array}$} & S-M\&D-1 & 100 & 100 & \multirow[t]{3}{*}{ Loose } & \multirow[t]{3}{*}{1} \\
\hline & S-M\&D-2 & 200 & 200 & & \\
\hline & S-M\&D-3 & 400 & 400 & & \\
\hline & S-M\&D-4 & 100 & 100 & \multirow[t]{3}{*}{ Dense } & \multirow[t]{3}{*}{1} \\
\hline & S-M\&D-5 & 200 & 200 & & \\
\hline & S-M\&D-6 & 400 & 400 & & \\
\hline \multirow{6}{*}{$\begin{array}{l}\text { Ottawa } \\
\text { sand }\end{array}$} & S-M\&D-7 & 100 & 100 & \multirow[t]{3}{*}{ Loose } & \multirow[t]{3}{*}{1} \\
\hline & S-M\&D-8 & 200 & 200 & & \\
\hline & S-M\&D-9 & 400 & 400 & & \\
\hline & S-M\&D-10 & 100 & 100 & \multirow[t]{3}{*}{ Dense } & \multirow[t]{3}{*}{1} \\
\hline & S-M\&D-11 & 200 & 200 & & \\
\hline & S-M\&D-12 & 400 & 400 & & \\
\hline \multirow{7}{*}{$\begin{array}{l}\text { Fraser } \\
\text { River sand }\end{array}$} & S-M\&D-13 & 133 & 266 & \multirow[t]{5}{*}{ Loose } & 0.5 \\
\hline & S-M\&D-14 & 160 & 240 & & 0.67 \\
\hline & S-M\&D-15 & 240 & 160 & & 1.5 \\
\hline & S-M\&D-16 & 150.6 & 224.7 & & 0.67 \\
\hline & S-M\&D-17 & 257.1 & 171.4 & & 1.5 \\
\hline & S-M\&D-18 & 128.6 & 85.7 & \multirow[t]{2}{*}{ Dense } & 1.5 \\
\hline & S-M\&D-19 & 75 & 112.4 & & 0.67 \\
\hline
\end{tabular}




\section{Monotonic and Cyclic behavior of Leda clay}

\subsection{Introduction}

This chapter presents and discusses the undrained monotonic and cyclic behavior of sensitive Leda clay samples obtained from Breckenridge and Outardes-2 sites. Undrained monotonic test results and its dependency on different factors are discussed in the first part of this chapter. Cyclic test results are investigated in the subsequent sections and finally the cyclic test results obtained from this experimental triaxial research are compared with the reported results for the same material under simple shear loading.

\subsection{Monotonic behavior of Leda clay}

Undrained monotonic triaxial compression tests were conducted on undisturbed sensitive clay samples retrieved from Breckenridge and Ourtardes-2. Breckenridge samples from about $21 \mathrm{~m}$ and $28 \mathrm{~m}$ depths were tested at an isotopically consolidated stress level just above their in-situ stress level. Set of samples obtained at same depth level from Brackenridge (TO-15@21.74m) were also tested at different consolidation pressures to study the effects of OCR on the monotonic behavior of sensitive clay. Also, a sample from Outardes-2 (TM-2C@11.06m) was tested at in-situ over consolidated state. All these monotonic tests were conducted on isotopically consolidated samples at an axial strain rate of $1 \%$ per hour. The strain rate was chosen to ensure equalization of pore water pressure throughout the sample during shearing, and was calculated according to ASTM D 4767. The results of all monotonic tests are summarized in table 4.1. 
Table 4-1 Monotonic results summary

\begin{tabular}{|c|c|c|c|c|c|c|c|}
\hline \multirow[t]{2}{*}{ Test ID } & \multirow[t]{2}{*}{ Sample } & \multirow{2}{*}{$\begin{array}{c}\text { Depth } \\
\text { (m) }\end{array}$} & \multicolumn{2}{|c|}{ Consolidation } & \multirow[t]{2}{*}{$\mathrm{S}_{\mathrm{u}}(\mathrm{kPa})$} & \multicolumn{2}{|c|}{ Strength ratio } \\
\hline & & & $\sigma_{c}^{\prime}(\mathrm{kPa})$ & $P_{c}^{\prime}(\mathrm{kPa})$ & & $S_{u} / \sigma_{c}^{\prime}$ & $S_{u} / P_{c}^{\prime}$ \\
\hline MON-1 & $\begin{array}{l}\text { BRK, } \\
\text { TO-19 }\end{array}$ & 27.85 & 200 & 200 & 98.1 & 0.49 & 0.49 \\
\hline MON-2 & $\begin{array}{l}\text { BRK, } \\
\text { TO-20 }\end{array}$ & 27.73 & 200 & 200 & 125.3 & 0.63 & 0.63 \\
\hline MON-3 & $\begin{array}{c}\text { BRK, } \\
\text { TO-17 }\end{array}$ & 21.56 & 150 & 150 & 76 & 0.51 & 0.51 \\
\hline MON-4 & $\begin{array}{l}\text { BRK, } \\
\text { TO-15 }\end{array}$ & 21.74 & 400 & 400 & 102.5 & 0.26 & 0.26 \\
\hline MON-5 & $\begin{array}{l}\text { BRK, } \\
\text { TO-15 }\end{array}$ & 21.74 & 100 & 150 & 63.5 & 0.64 & 0.42 \\
\hline MON-6 & $\begin{array}{l}\text { BRK, } \\
\text { TO-15 }\end{array}$ & 21.74 & 50 & 150 & 48.2 & 0.96 & 0.32 \\
\hline MON-7 & $\begin{array}{c}\text { OUT, } \\
\text { TM-2C }\end{array}$ & 11.06 & 131 & 400 & 139.2 & 1.06 & 0.35 \\
\hline
\end{tabular}

Here $\sigma_{c}^{\prime}$ is the effective consolidation pressure and $P_{c}^{\prime}$ is the effective preconsolidation pressure. At in-situ stress level, pre-consolidation pressures of samples TO19, TO-20, TO-17, TO-15 and TM-2C were reported to be 200, 200, 150, 150 and 400 kPa respectively (Blanchette, 2016).

Stress-strain behavior and strength characteristics of soils are often assessed using 
normalized parameters in order to isolate the effects of confining stress level. Effective consolidations stress $\left(\sigma_{c}^{\prime}\right)$ and overconsolidation ratio $(O C R)$ significantly influence the behavior of soils, and Leda clay is no exception. Normalized peak shear strength $\left(S_{u} / \sigma_{c}^{\prime}\right)$ of Leda clay consolidated to the in-situ stress state varies considerably from site to site. Values of $S_{u} / \sigma_{c}^{\prime}$ ranging from about 0.26 to 1.06 have been measured depending on the in-situ OCR. However, the variances can be minimized by using the pre-consolidation pressure (maximum in - situ, $p_{c}^{\prime}$ ) as the normalizing parameter. The measured values for $S_{u} / p_{c}^{\prime}$ ratio vary between 0.26 and 0.63 , which is a narrower variation compared to $S_{u} / \sigma_{v c}^{\prime}$ ratio. It should be noted that there is some uncertainty in the determined $p_{c}^{\prime}$ values, which have been obtained from consolidation tests (Blanchette, 2016) on undisturbed samples.

Figure 4.1 shows a typical monotonic stress - strain curve, pore water pressure generation with axial strain, and the stress path of a tested sensitive clay sample (BRK TO-19@27.85m) at $200 \mathrm{kPa}$ consolidation stress. It can be observed that the shear stress $(\tau)$ initially increases with axial strain and then reaches a clear peak strength $\left(S_{u}\right)$ at $1.3 \%$ of axial strain. Further increment in axial strain causes strain softening in the sample and the shear strength reaches a residual strength at very large strains. Also, the pore water pressure steadily increases with axial strain and the stress path moves towards the origin. Similar stress - strain behavior for sensitive clays has been reported by many researchers (e.g. Lee, 1979; Lefebvre at al., 1989; Theenathayarl, 2015; Thirugnanasampanther, 2016). 


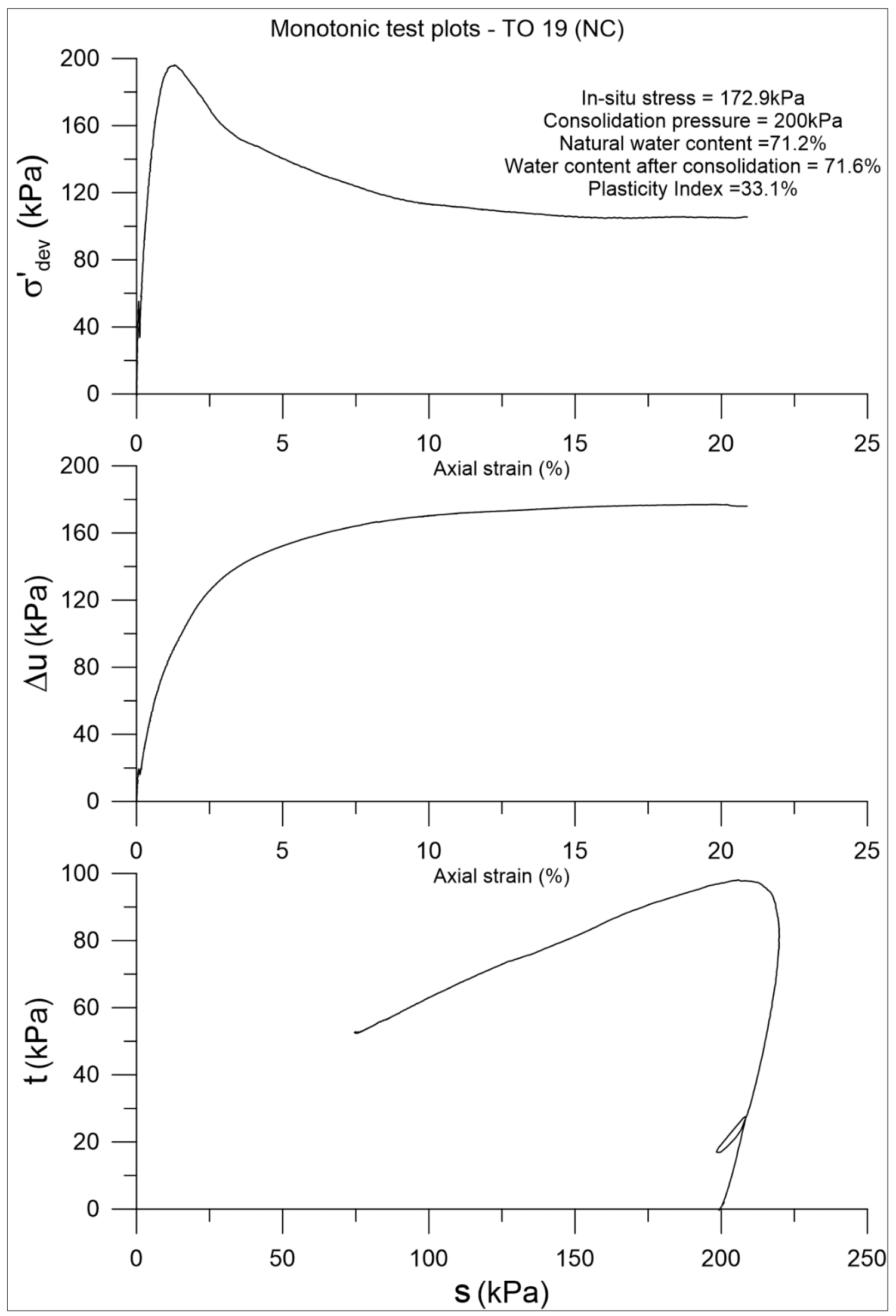

Figure 4-1 Undrained monotonic behavior of Leda clay 


\subsubsection{Effect of consolidation pressure}

Undrained monotonic tests were conducted on samples from the same block (BRK TO-15@21.74m) at different consolidation pressures $\sigma_{c}^{\prime}(400 \mathrm{kPa}, 100 \mathrm{kPa}$ and $50 \mathrm{kPa}$ ) to study the effect of $\sigma_{c}^{\prime}$ on monotonic behavior. Figure 4.2 shows a comparison of these results. An increasing peak shear strength can be observed with increasing consolidation pressure. Furthermore, a clear peak strength is noticed at higher consolidation pressures $(400 \mathrm{kPa}$ and $100 \mathrm{kPa})$, but the peak is not clearly visible at lower values of $\sigma_{c}^{\prime}$. Differences in OCR would also contribute to the observed differences in the behaviour.

Peak shear strengths were obtained at axial strain values ranging from $1 \%$ to $4 \%$ and these strain values were observed to increase slightly with the increasing consolidation pressure. Similar patterns have also been reported in literature (e.g. Lee, 1979; Theenathayarl, 2015). It should be noted that not only the consolidation pressure but also the over consolidation ratio is an important factor affecting the stress - strain behavior shown in Figure 4.2.

\subsubsection{Effect of over consolidation ratio}

The over consolidation ratio is a critical factor which controls the stress - strain behavior of clays. To study the OCR effects on monotonic behavior of sensitive Breckenridge and Outardes-2 clays, tests were carried out at different stress levels including normally and overly consolidated states and the results have been presented in the normalized form in Figure 4.3 to highlight the influence of OCR.

Normalized stress - strain curves of sensitive clays clearly show that the 
normalized shear strength $\left(S_{u} / \sigma_{c}^{\prime}\right)$ of overconsolidated clay is significantly higher than that of normally consolidated clay, and it increases with increasing OCR values. Normalized stress - strain curves, excess pore water pressure curves and the stress paths of NC samples fall in a narrow range, but the overly consolidated samples show a noticeably deviated trend.

The $S_{u} / \sigma_{c}^{\prime}$ ratio of normally consolidated clays takes a value more or less equal to 0.5 , but in OC clays this value may vary with OCR ratios and clay types. The Breckenridge samples from the same bore hole (TO-15) tested at different OCR (1.5 and 4) takes $S_{u} / \sigma_{c}^{\prime}$ values of 0.64 and 0.96 respectively. The Ourtardes-2 sample tested at an OCR of 3 takes a higher $S_{u} / \sigma_{c}^{\prime}$ value of 1.06. Also, it is noticeable form the normalized stress - strain curves that the NC clays reach their peak shear strength relatively at a smaller axial strain than the OC clays. These observations are similar to the behavior of sensitive clays reported in the literature (Theenathayarl, 2015; Thirugnanasampanther, 2016) under simple shear loading mode.

Normally consolidated samples generate a higher normalized pore water pressure $\left(\Delta U / \sigma_{c}^{\prime}\right)$ than the over consolidated samples (Figure 4.3). This can be related to the lower peak strength in NC clays. Therefore, the $\Delta U / \sigma_{c}^{\prime}$ curves are very similar for NC clays, but deviate significantly in OC clays. Similar trends have also been observed in the normalized stress path plots.

Sensitive clay's micro structure is prone to collapsing at higher consolidation stresses and therefore results in a lower peak strength than the expected value. The normalized stress - strain behavior of Breckenridge sample tested at $400 \mathrm{kPa}$ (TO-15, NC) slightly deviates from the trend observed for other NC samples. This strength 
reduction may be due to the collapse of microstructure at higher consolidation stress level.

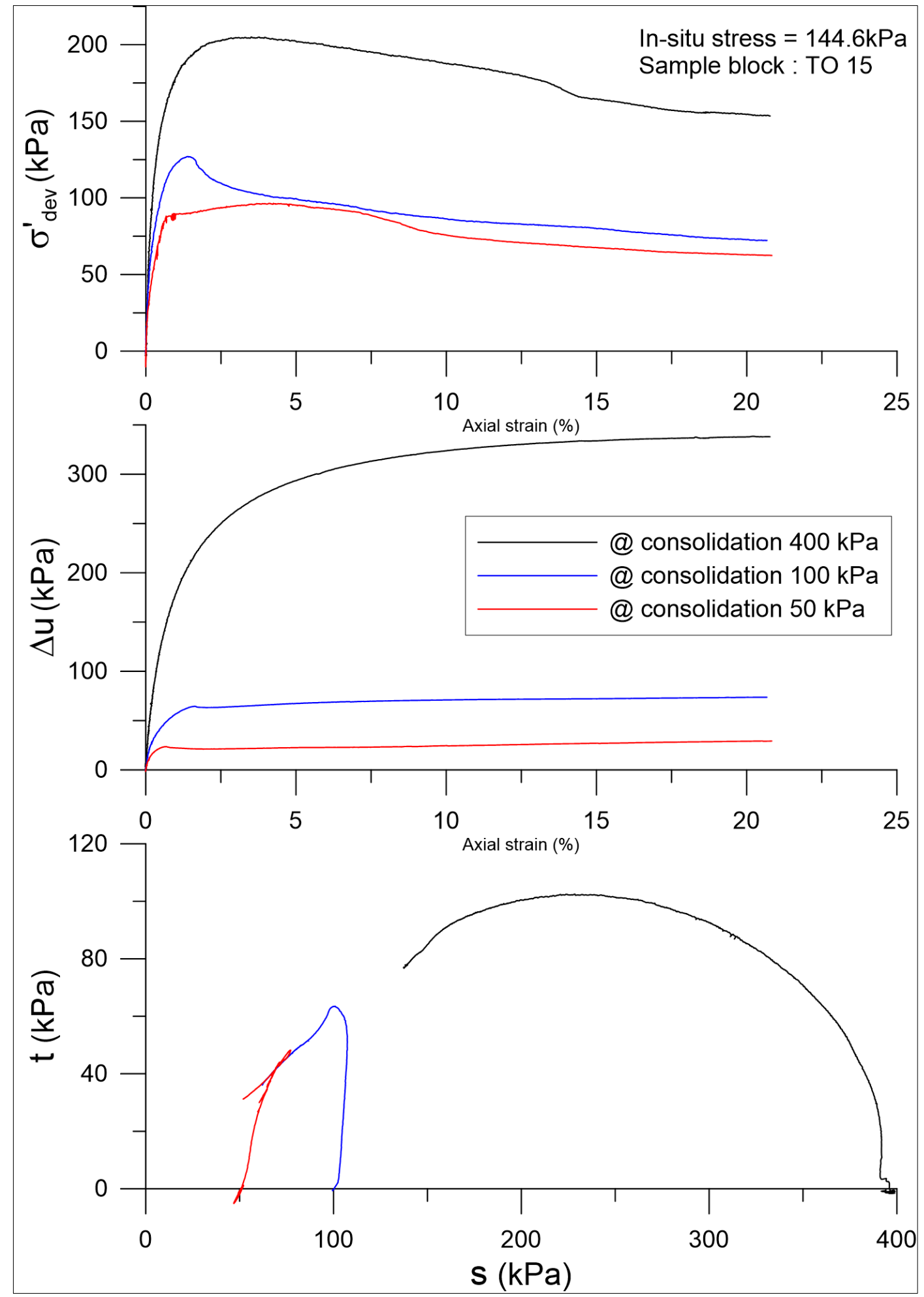

Figure 4-2 Comparison of Monotonic behavior of Leda clay under different consolidation pressures 


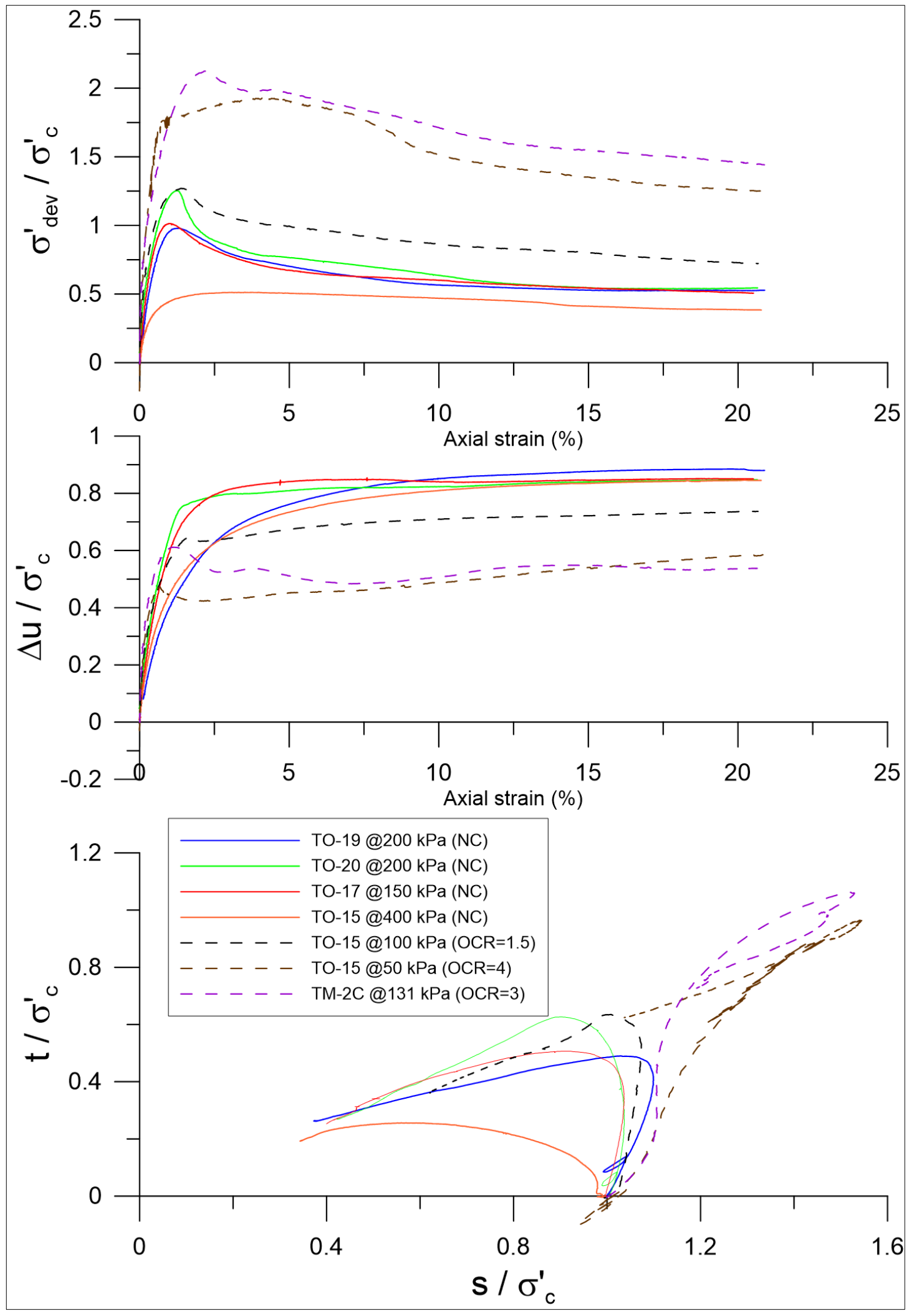

Figure 4-3 Comparison of normalized monotonic behavior of Leda clay 
Other factors which influence the monotonic behavior of sensitive clays in addition to the stress history are Plasticity index, sensitivity, water content at the end of consolidation, and percentage and type of clay particles present. But, the available undisturbed material was not sufficient to study the effects of these parameters.

\subsubsection{Monotonic strength parameters of Leda clay}

Data points corresponding to peak and residual stress states are plotted in Figures 4.4 and 4.5 in order to obtain the monotonic strength parameters, internal effective friction angle $\left(\varphi^{\prime}\right)$ and effective cohesion $\left(c^{\prime}\right)$. However, the available data points are not enough to draw a best fit line and obtain the strength parameters for NC and OC states seperatly. At peak stress state Brackenridge samples show an average effective friction angle of $20.3^{\circ}$ with $25.7 \mathrm{kPa}$ of cohesion. However, two data points are outliers (Figure 4.4) at peak state, while data points at residual state show a relatively linear trend (Figure 4.5 ) and yield an effective friction angle of $34.5^{\circ}$ with $4.17 \mathrm{kPa}$ of cohesion.

It should also be noted that undisturbed samples obtained from Outardes- 2 sites have been determined to be high quality, but concerns have been expressed about the quality of some Breckenridge samples. Fissures have been noted more frequently in Breckenridge (Figure 4.6) samples compared to Outardes-2. Eden and Crawford (1958) have reported that fissured layers at some locations extend well below the top weathered crust. These issues would also affect the reliability of the measured data to some extent, and might explain the variances noted in the $\varphi^{\prime}$ values. 


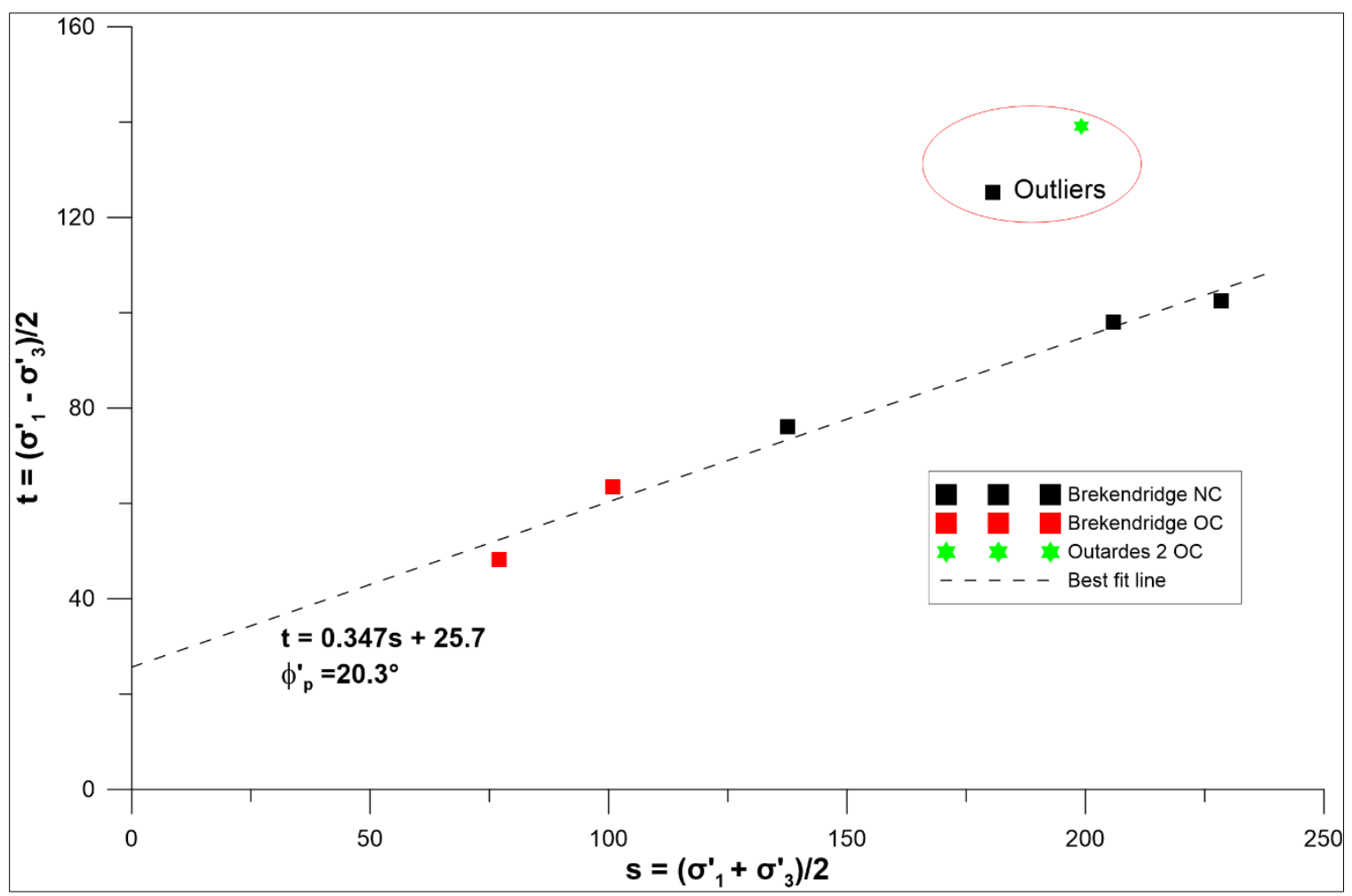

Figure 4-4 Peak strength parameters of Leda clay

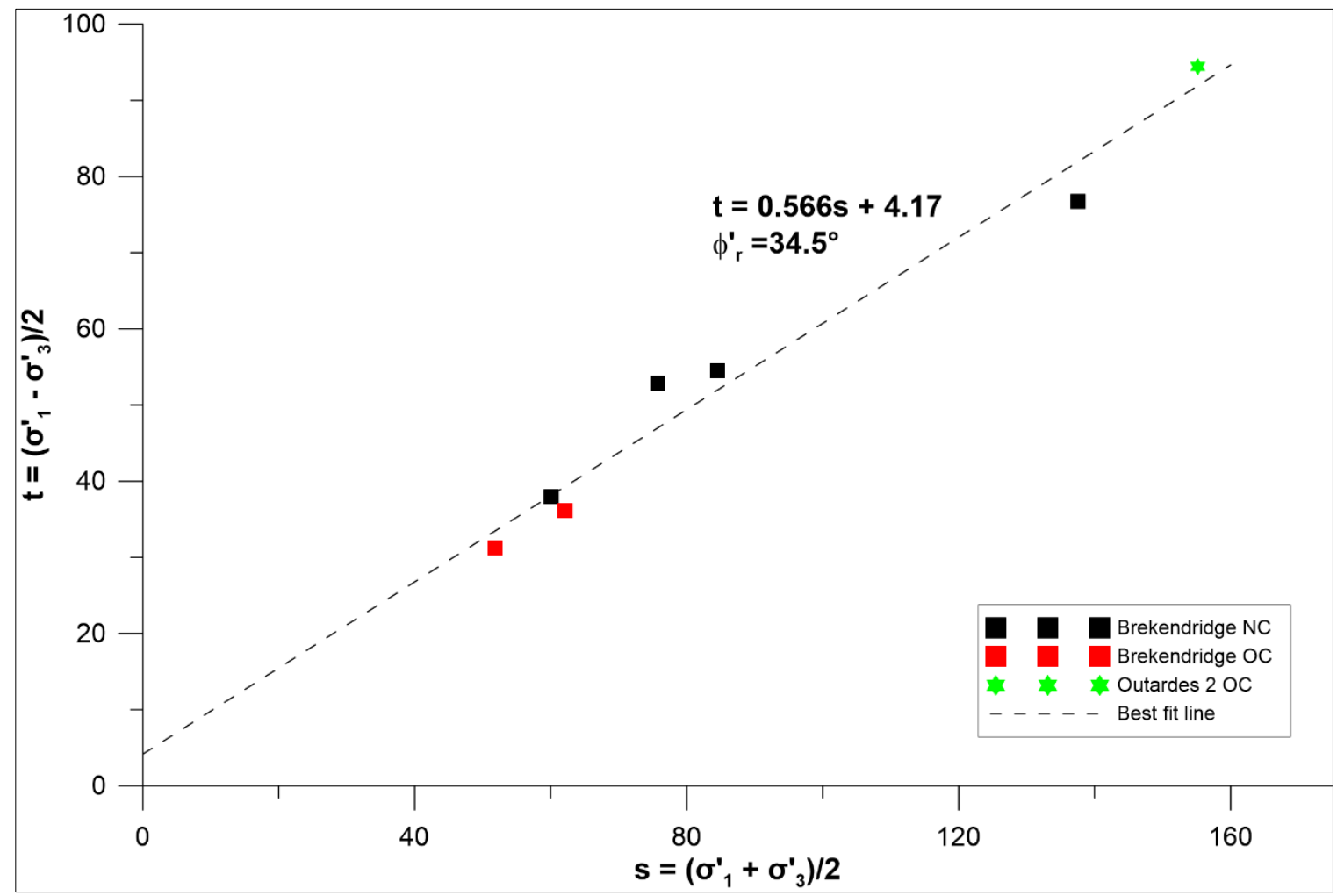

Figure 4-5 Residual strength parameters of Leda clay 
Some simple shear monotonic tests were conducted on similar Leda clay samples by Thirugnanasampanther (2016). The peak strength mobilized in these triaxial tests at in-situ stress levels was somewhat larger compared to that in simple shear. Breckenridge clay at the same OCR level mobilized an $S_{p} / \sigma_{v c}^{\prime}=0.34$ in simple shear and 0.51 in triaxial compression; Outardes-2 clay at $\mathrm{OCR}=3.1$ mobilized an $S_{p} / \sigma_{v c}^{\prime}=0.51$ in simple shear, but almost 1.1 in triaxial compression. Similar trends can be noted by comparing the simple shear and triaxial compression test results presented by Blanchette (2016). These observations demonstrate that the response of sensitive Leda clay is stress-path dependent.

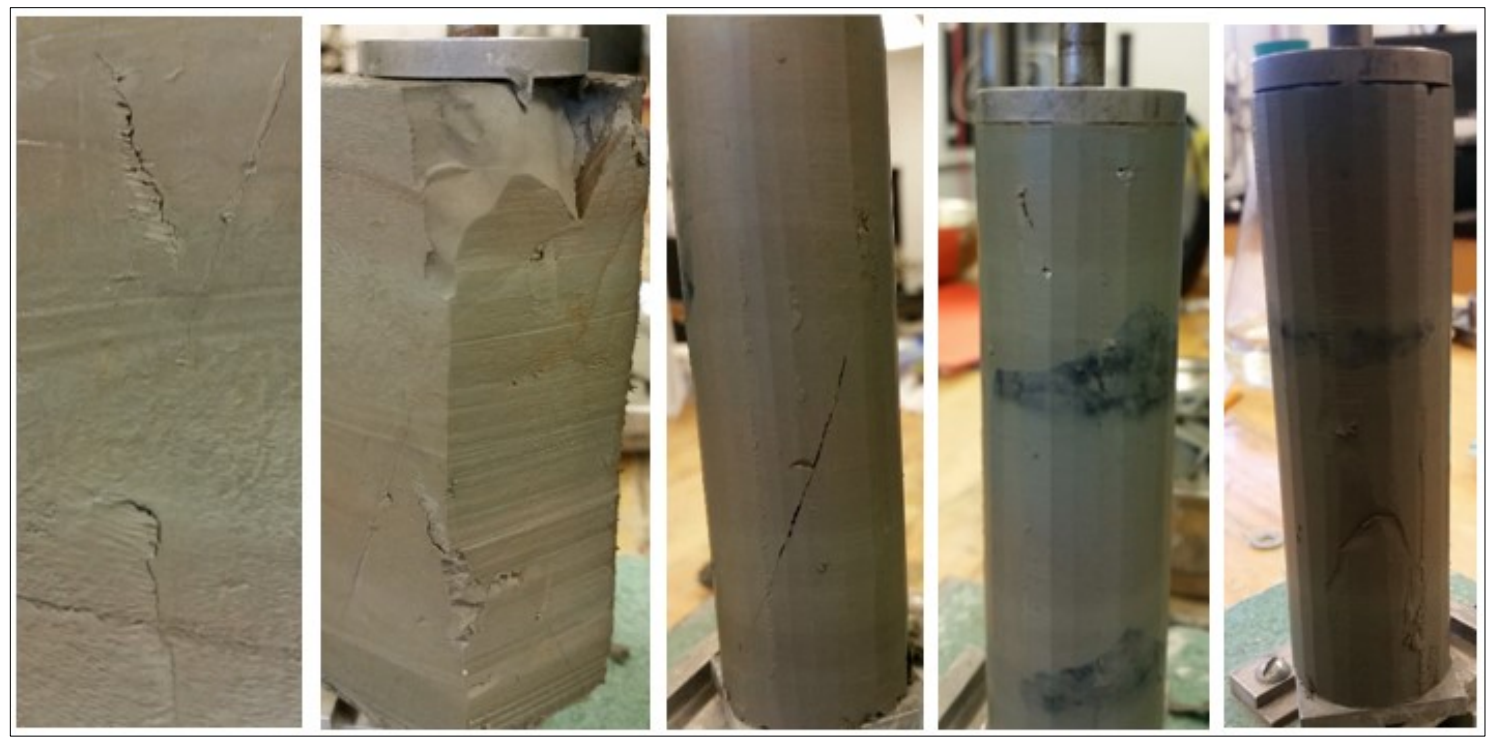

Figure 4-6 Cracks and fissures in Breckenridge samples 


\subsection{Cyclic behaviour of sensitive Leda clay}

Cyclic tests were conducted on undisturbed Leda clay samples obtained from Breckenridge and Outardes-2 under triaxial conditions. All samples were carefully prepared as mentioned in chapter 3 and tested under isotopically consolidated states. In order to test identical samples (as much as possible), sets of samples were taken from each sample blocks (TO-19, TO-20, TO-17 and TM-2C) and tested at different cyclic deviatoric stress amplitudes. All the tests were conducted at a consolidation stress level nearly equal to the samples' in-situ stress levels.

Stress controlled cyclic loading was applied to the consolidated sample in a sinusoidal wave form with a constant frequency of $0.1 \mathrm{~Hz}(\mathrm{~T}=10 \mathrm{~s})$ using a double acting piston. True liquefaction does not occur in cohesive soils because $100 \%$ excess pore water pressure during cyclic loading does not generally occur in clay. Even, if it does occur and the effective stress reaches zero, the clay could exhibit strength on account of cohesion. In this regard, liquefaction in clay is defined as the unacceptable deformation of soil, and therefore in this study the cyclic loading was continued until the sample reached an axial strain of $2.5 \%$ (which is equal to a shear strain of $3.75 \%$ ). The sample can be considered as liquefied at this level of strain as recommended by NRC (1985).

The number of equivalent sinusoidal loading cycles for an earthquake loading is primarily related to the intensity of earthquake. As discussed in the literature, a typical earthquake could trigger between 1 to 40 equivalent sinusoidal loading cycles. Therefore, the cyclic deviatoric stresses were chosen carefully in each test with the target of failing the sample from a few to few hundred cycles. The first cyclic deviatoric stress level was estimated from the monotonic shear strength value of identical tested sample. Thereafter, 
the consequent cyclic stress levels were determined using the outcome of first cyclic test to obtain the number of cycles close to the targeted values.

A typical cyclic test result is demonstrated in Figures 4.7 and 4.8. The test was conducted on a Breckenridge sample (TO-19) at normally consolidated stress of $200 \mathrm{kPa}$ (just above the in-situ stress level). A constant sinusoidal deviatoric stress with a peak amplitude of $148.3 \mathrm{kPa}$ was applied to the consolidated sample under undrained conditions. The figure shows the applied deviatoric stress, excess pore water pressure generation, and the axial strain progression in the sample with loading cycles. As seen in Figure 4.7, the sample liquefied (i.e., axial strain exceeded 2.5\%) at the $18^{\text {th }}$ loading cycle.

As shown in Figure 4.7, the excess pore water pressure $(\Delta U)$ continuously increases with the number of loading cycles $(\mathrm{N})$ and decreases the effective stresses $\left(\sigma_{1}^{\prime} \& \sigma_{3}^{\prime}\right)$ in the sample. As a result, the sample becomes weaker with the number of loading cycles and the axial strain increases gradually. The stress - strain behavior and stress paths of the sample during the cyclic loading are shown in Figure 4.8.

The strain development in the sample is not symmetric in compression and extension. This is a reflection of the presence of anisotropic fabric and the differences in the loading conditions during triaxial compression and extension loading phases. The response of soil is stronger in compression and weaker in the extension loading mode, as discussed in chapter two. 


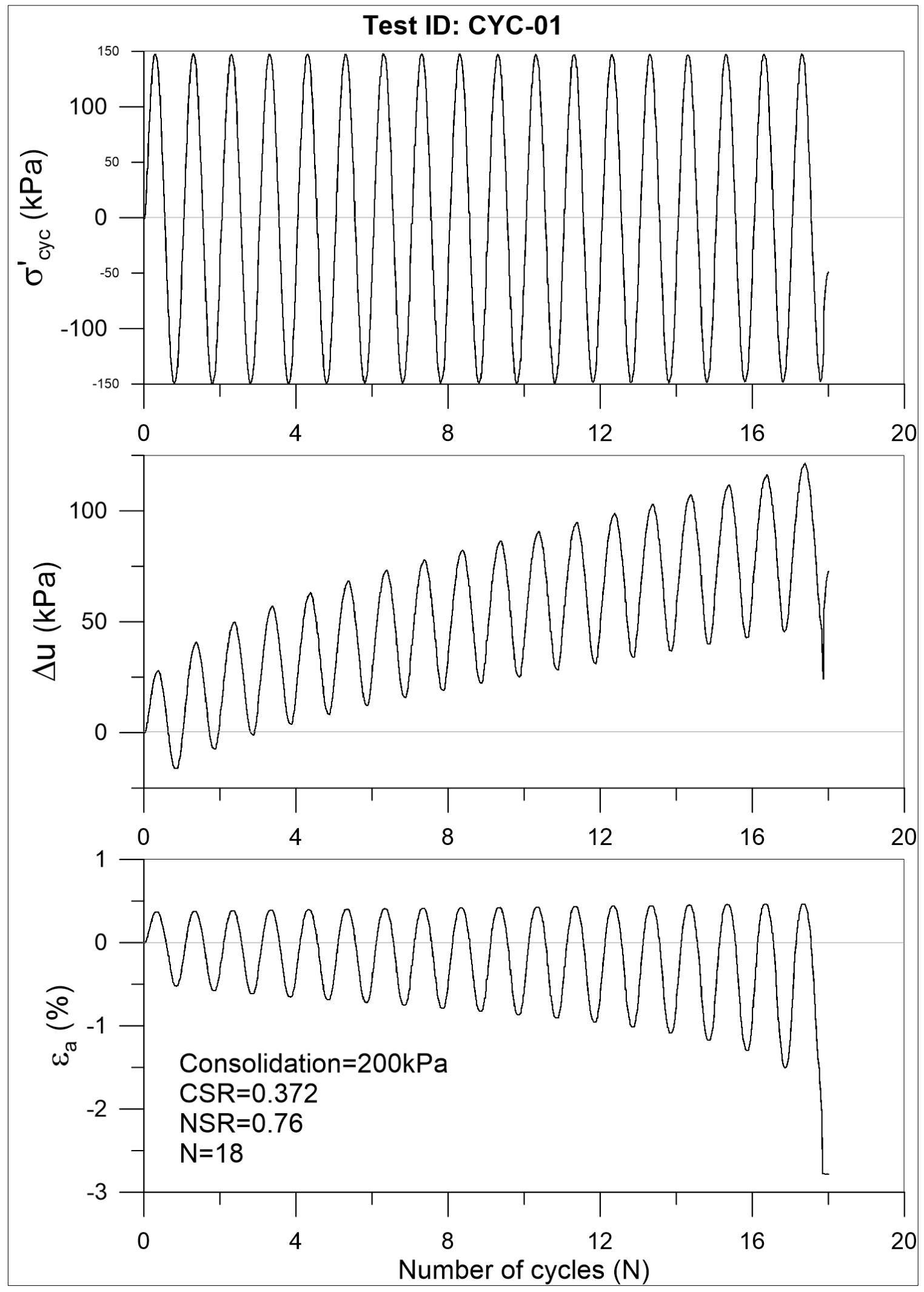

Figure 4-7 Cyclic behavior of Breckenridge clay (deviatoric stress, excess pore water pressure and Axial strain variation with number of loading cycles) 


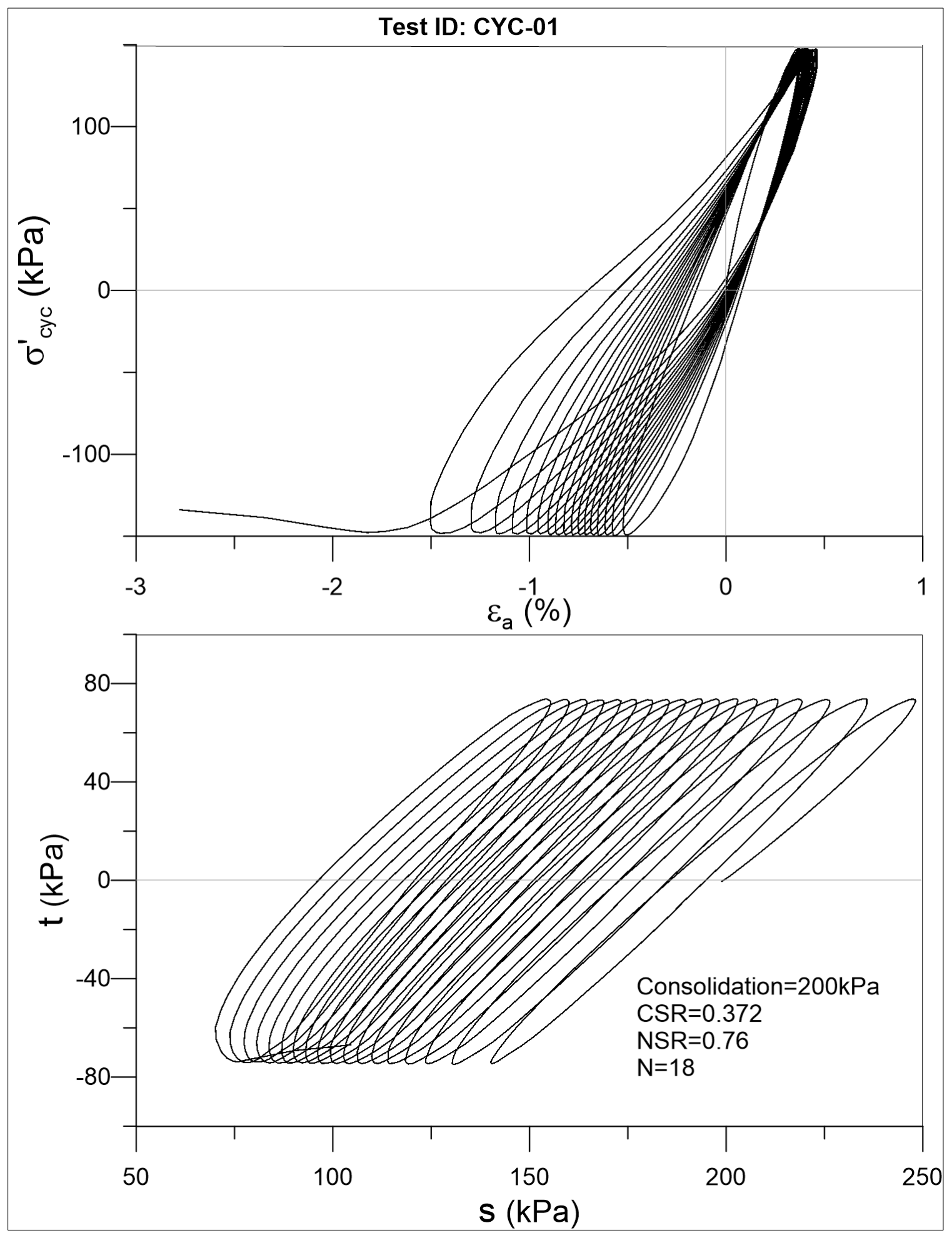

Figure 4-8 Cyclic behavior of Breckenridge clay (stress-strain and stress paths) 
All the cyclic tests conducted as a part of this study failed in the extension mode. Also, it should be noted that all the Breckenridge samples failed suddenly with rapidly increasing axial strain in the extension mode, and cause significant necking in the sample. Therefore, no post cyclic study could be conducted on these failed samples. Figure 4.9 shows a critically failed Breckenridge sample during cyclic loading. The axial strain development in Outardes-2 samples was gradual until failure, i.e., no sudden failure was observed. Figures 4.10 and 4.11 explain the typical Outardes- 2 clay behavior under cyclic loading.

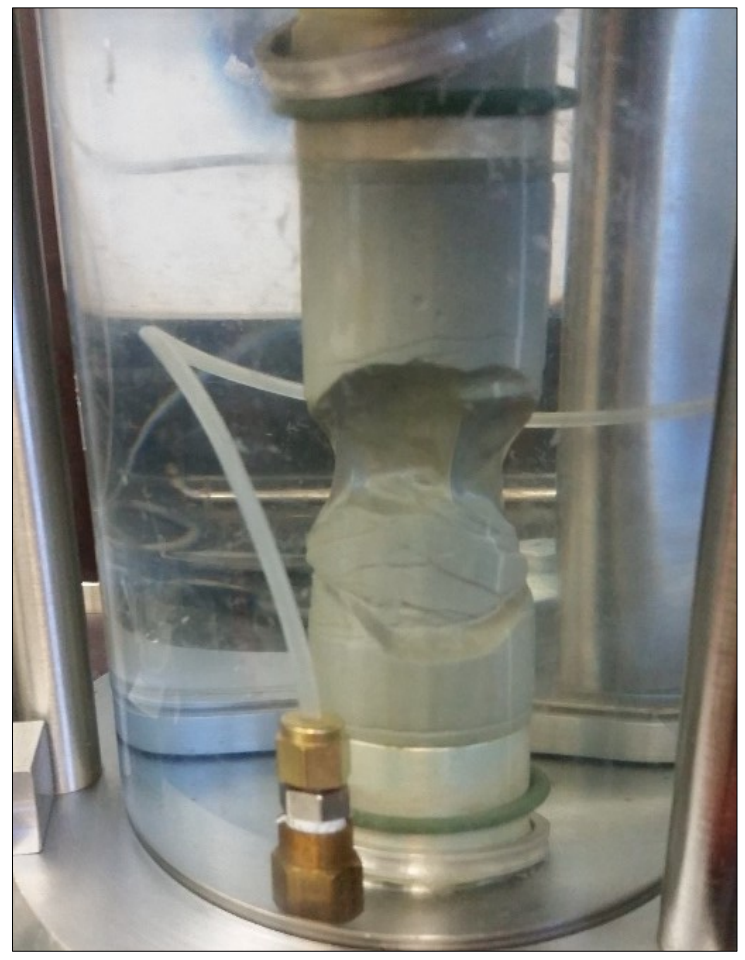

Figure 4-9 Cyclic loading failure mode of Breckenridge sample 


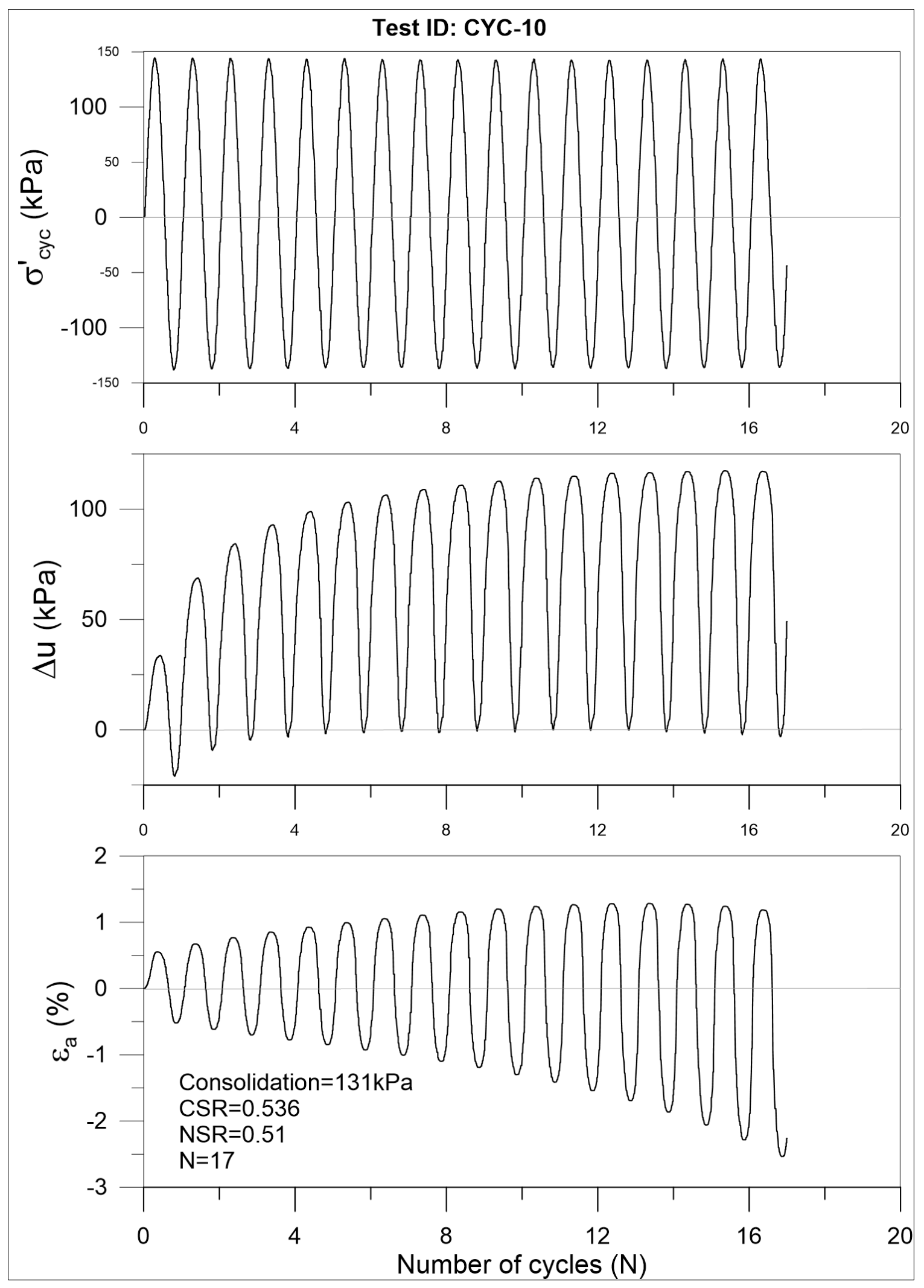

Figure 4-10 Cyclic behavior of Outardes-2 (deviatoric stress, excess pore water pressure and Axial strain variation with number of loading cycles) 


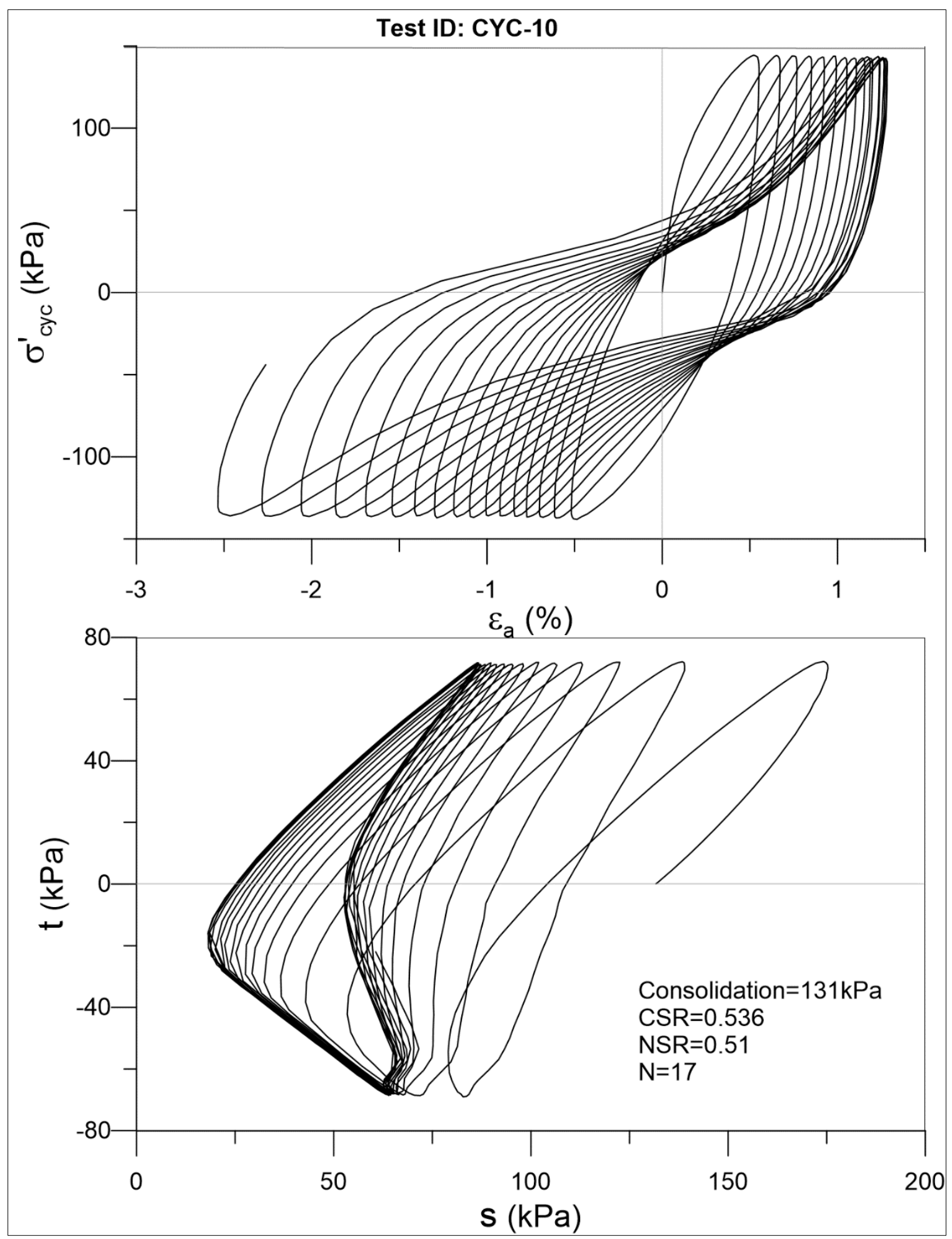

Figure 4-11 Cyclic behavior of Outardes-2 clay (stress-strain and stress paths) 


\subsubsection{Effect of cyclic stress amplitude and number of cycles}

The main focus of this section is to determine the number of loading cycles required to cause failure at a given cyclic stress ratio, CSR which defines the intensity of loading as a fraction of the effective confining stress, or normalized stress ratio, NSR which defines the intensity as a percentage of $S_{u}$. A set of similar specimens were prepared and tested at different cyclic stress amplitudes from both sites. The initial plan was to test Breckenridge and Ourdes-2 samples at in-situ and higher stress levels, but a very high volumetric strain was observed during the higher consolidation stress levels (Figure 4.12), and therefore these specimens were deemed unsuitable for cyclic tests

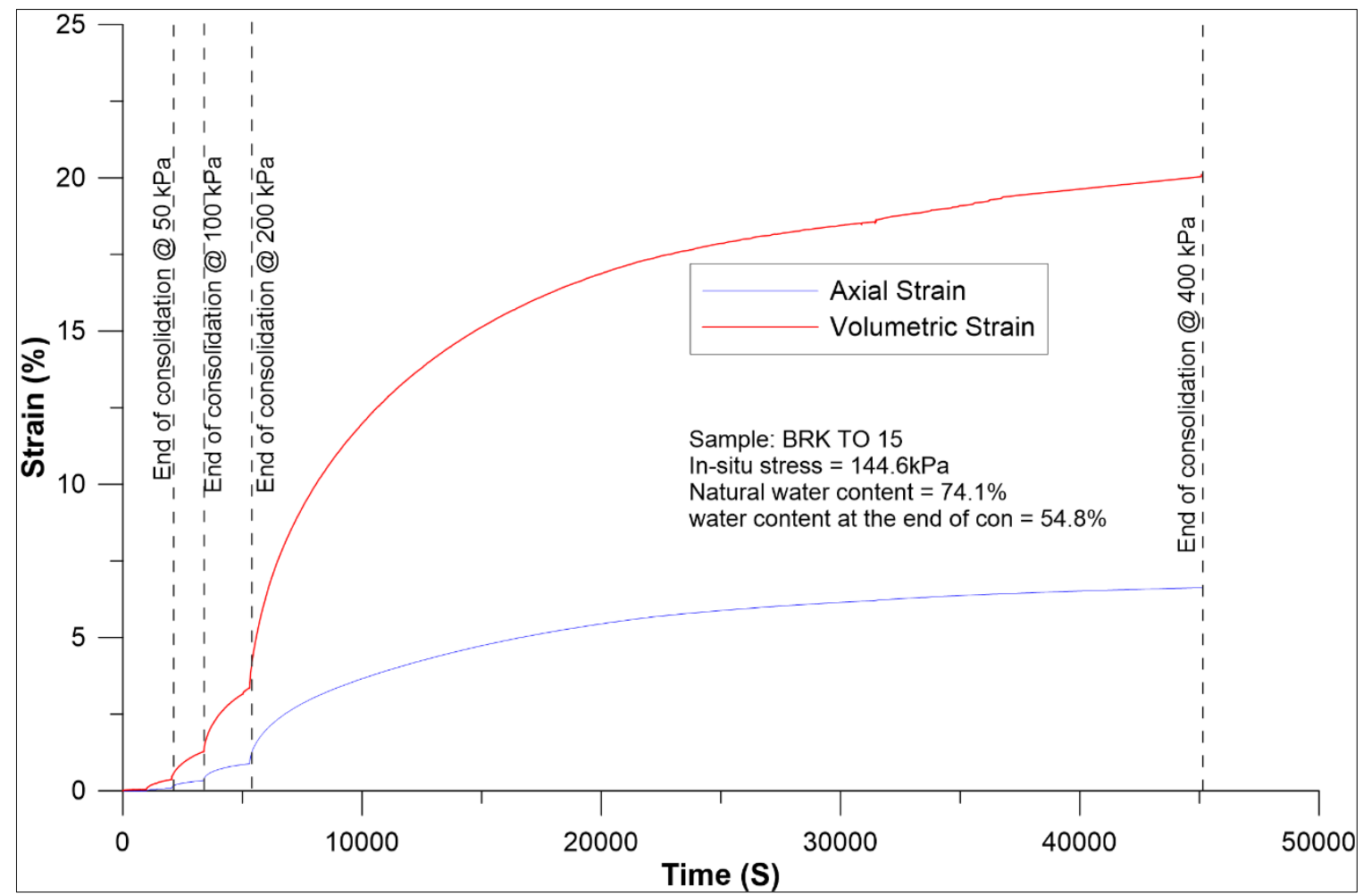

Figure 4-12 Very high volumetric strain during the high consolidation pressure

because of nonuniform deformed shape at the end of consolidation (Figure 4.13). The use of "frictionless end platens" would be necessary to test this material at such high stress levels. All the tests were thus conducted only at the in-situ stress levels or just above it. In 
order to present the cyclic strength of clay in percentage of $S_{u}$, some monotonic tests were conducted prior to the cyclic tests at the same confining pressure (as in cyclic tests) to determine the $S_{u}$ of the samples. Three cyclic tests were performed at each confining stress level to represent the variation of CSR with the number of loading cycles, $\mathrm{N}$.

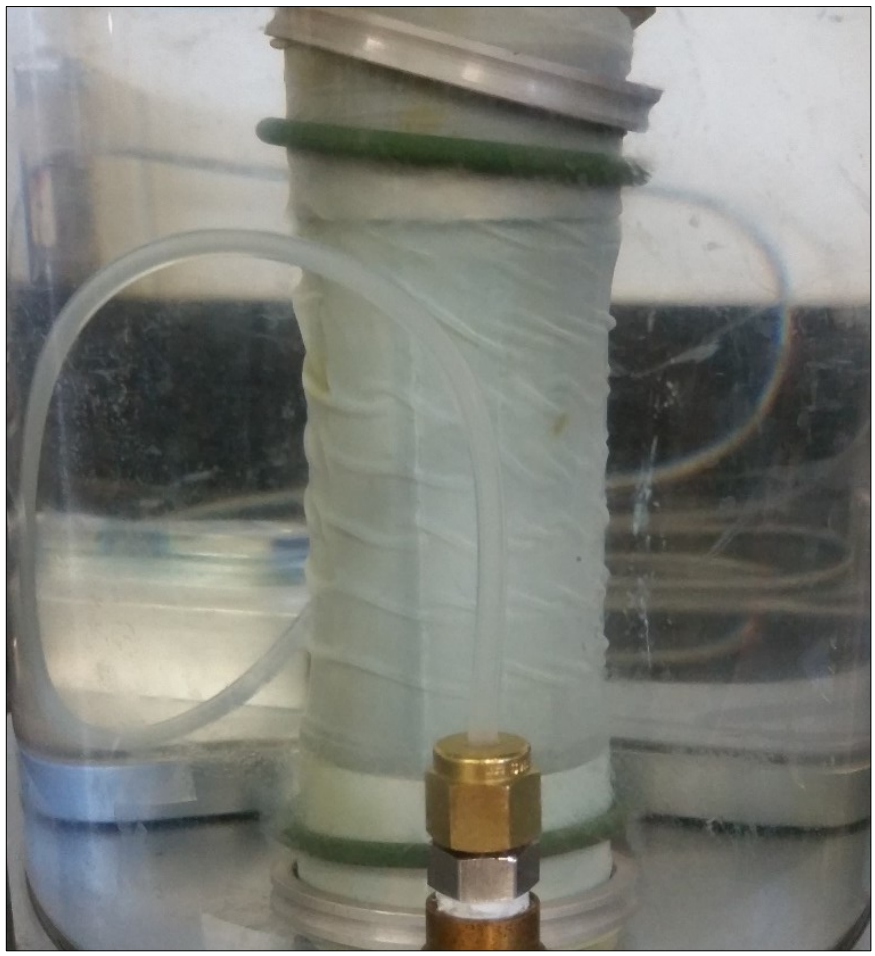

Figure 4-13 Deformed shape of the specimen after excess drainage at the end of high consolidation stress

\subsubsection{Cyclic resistance of Breckenridge clay}

Three sets of cyclic tests were conducted on Breckenridge samples obtained from three different bore holes (TO-19, TO-20 and TO-17). All the tests were conducted with the normally consolidated confining stress levels of $200 \mathrm{kPa}, 200 \mathrm{kPa}$ and $150 \mathrm{kPa}$ for the specimens from TO-19, TO-20 and TO-17 respectively. The number of loading cycles required to liquefy the sample have been plotted with the cyclic stress ratio (CSR) and normalized stress ratio $\left(N S R=\tau_{c y c} / S_{u}\right)$ in Figure 4.14 and 4.15 . 


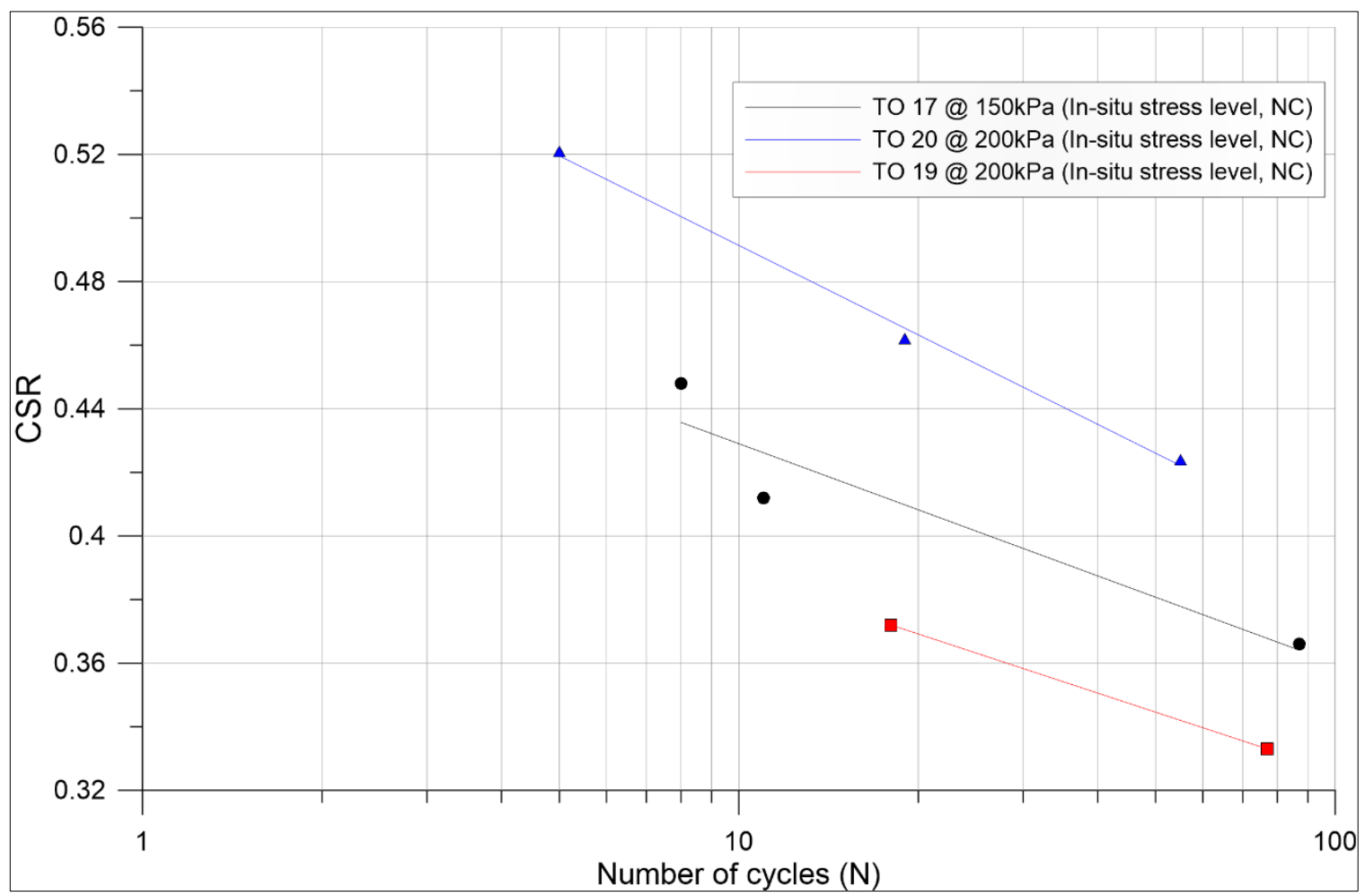

Figure 4-14 Cyclic resistance of Brackenridge samples (CSR vs N)

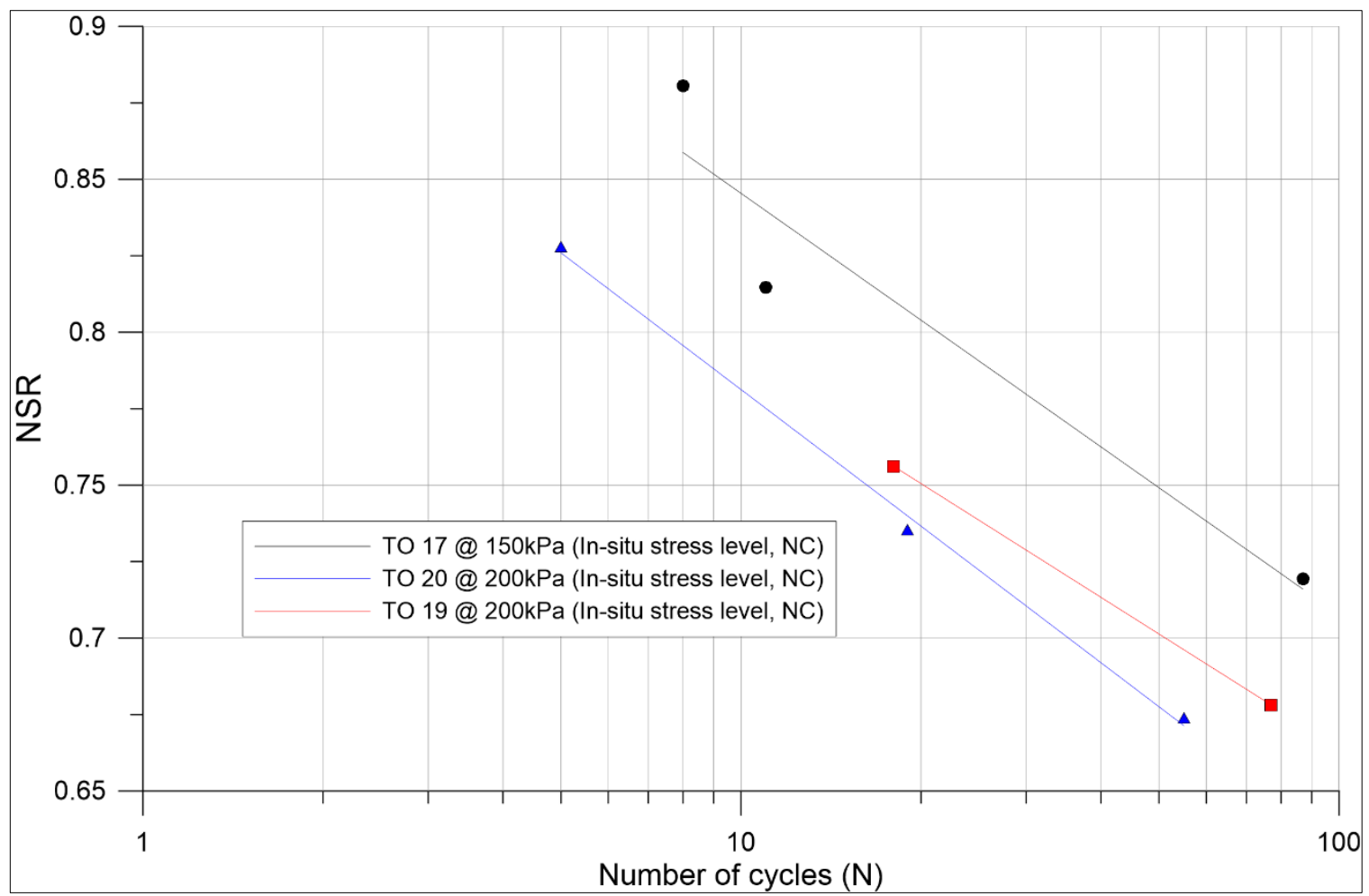

Figure 4-15 Cyclic resistance of Breckenridge samples (NSR vs N) 
For the specimens obtained from borehole TO-19 (consolidated at 200kPa), the number of cycles required to fail the sample were 18 and 77 at an applied cyclic deviatoric stress of $148.3 \mathrm{kPa}$ and $133 \mathrm{kPa}$ respectively. The specimens from borehole TO20 (consolidated at 200kPa) failed at 55, 19 and 5 cycles at an applied cyclic deviatoric stress of $168.9 \mathrm{kPa}, 184.3 \mathrm{kPa}$, and $207.5 \mathrm{kPa}$ respectively. The final set of samples obtained from the Breckenridge borehole TO-17 (consolidated at 150kPa) failed at 39, 17 and 10 cycles at an applied deviatoric stress of $129 \mathrm{kpa}, 141.2 \mathrm{kPa}$, and $158.3 \mathrm{kPa}$ respectively.

As shown in the Figure 4.15, the number of cycles required to liquefy the specimen increases with decrease in cyclic deviatoric stress for each borehole sample. Also, the samples from borehole TO-20 show a significantly higher cyclic resistance compared to the samples from TO-19 despite all the influencing parameters being more or less similar. These parameters include the in-situ stress level, pre-consolidation pressure, natural water content, water content at the end of consolidation state, volumetric and axial strain during consolidation, and the Atterberg limits. A similar trend was also observed in the results of the monotonic tests conducted on these samples, where the peak shear strength of TO-20 was $125.3 \mathrm{kPa}$ and the peak strength of TO-19 was $98.1 \mathrm{kPa}$. However, their residual shear strength values were nearly equal, as can be observed in the Figure 4.16. This behavior may be attributed to a possible disturbance in the sample obtained from borehole TO-19 as some surface cracks were also observed in that sample during preparation.

The cyclic resistance curve of specimens from borehole TO-17 falls between the curves obtained for samples from boreholes TO-19 and TO-20. Its normalized monotonic 
behavior was similar to TO-20 but the natural water content was slightly higher. The cyclic resistance in the normalized stress ratio $\left(N S R=\tau_{c y c} / S_{u}\right)$ plot falls in a narrow band compared to the CSR plot. Also, it is noticeable that in the NSR plots, samples from boreholes TO-19 and TO-20 show a similar trend.

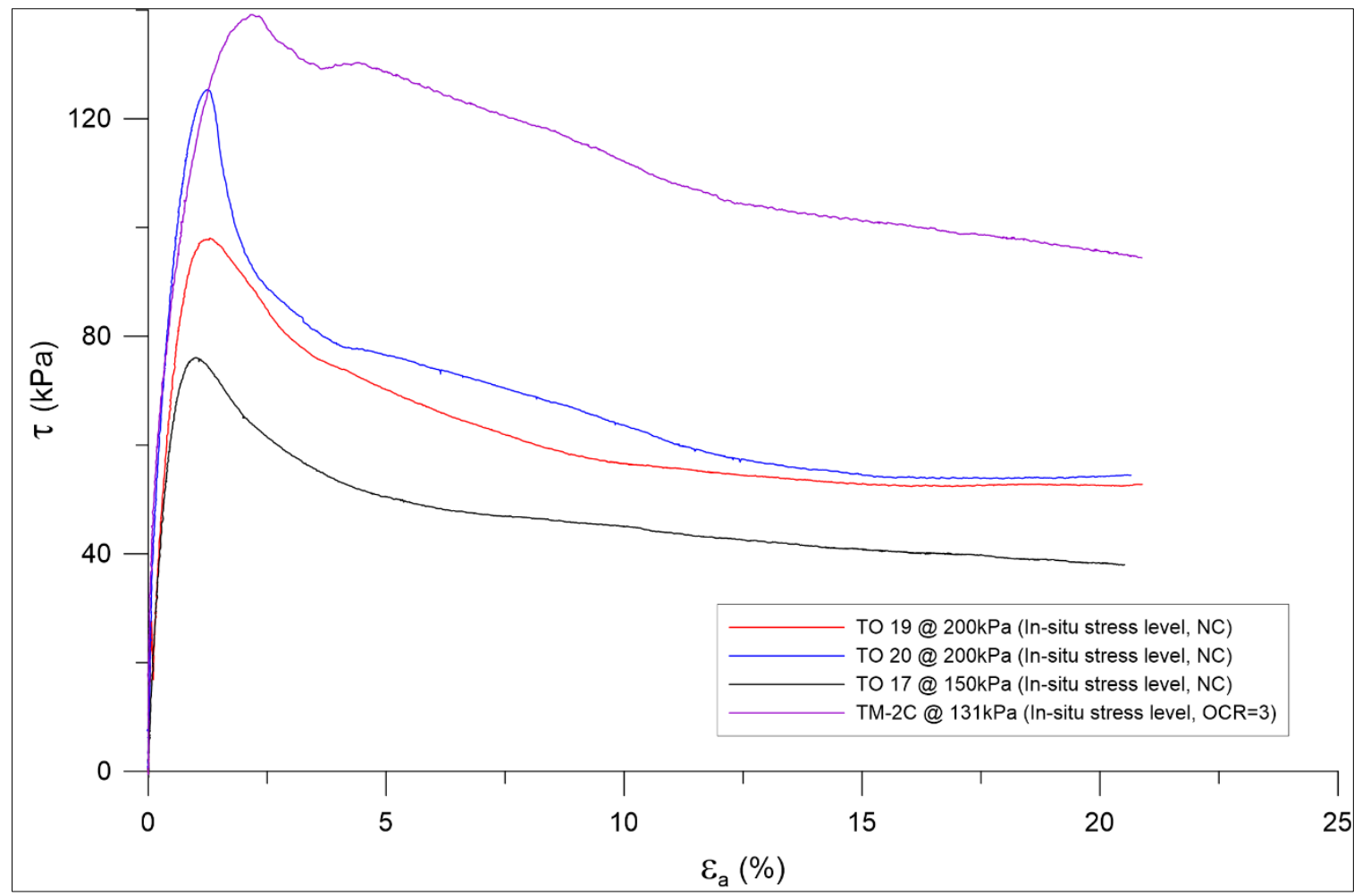

Figure 4-16 Monotonic response of Breckenridge and Ouratdes-2 samples

\subsubsection{Cyclic response of Ourardes-2 clay}

The pre-consolidation pressure of the sample obtained from borehole TM-2C (Outardes-2) is around $400 \mathrm{kPa}$, and at the in-situ stress level, it is over consolidated with an OCR value of 3 . Three cyclic tests were conducted on this sample at the in-situ stress level and the results have been shown in Figure 4.17. The cyclic resistance of Outardes-2 clay is higher than Breckenridge clay. Also, its normalized monotonic peak shear strength 
is very high compared to Brackenridge clay. The main reason for this is the higher OCR value with lower natural water content (31.2\%) in Outardes- 2 samples compared to the Breckenridge samples.

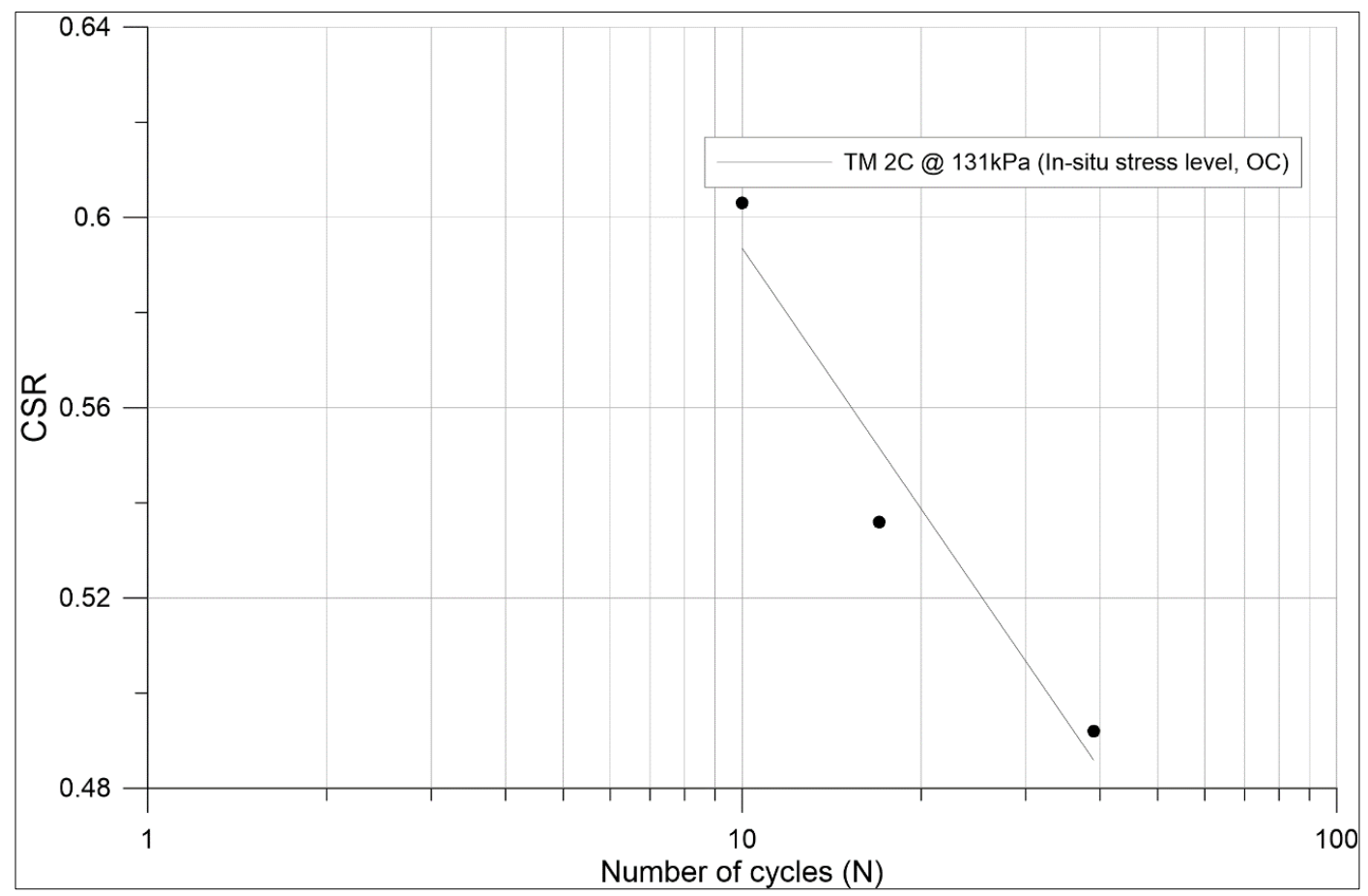

Figure 4-17 Cyclic resistance of Outardes-2 samples (CSR vs N)

\subsubsection{Comparison of cyclic resistance between Triaxial and Simple shear loading} conditions

Cyclic tests were performed on similar undisturbed samples from Breckenridge and Outardes-2 under simple shear loading conditions by Thirugnanasampanther (2016) and Blanchette (2016). It should be noted that the published simple shear cyclic loding was stopped when the sample reached a shear strain of $3.75 \%$ and these triaxial loading was stopped when the sample reached $2.5 \%$ of axial strain. But $2.5 \%$ of axial strain in undrained triaxial condition is equal to $3.75 \%$ shear strain, therefore these simple shear and triaxial results are comparable. 


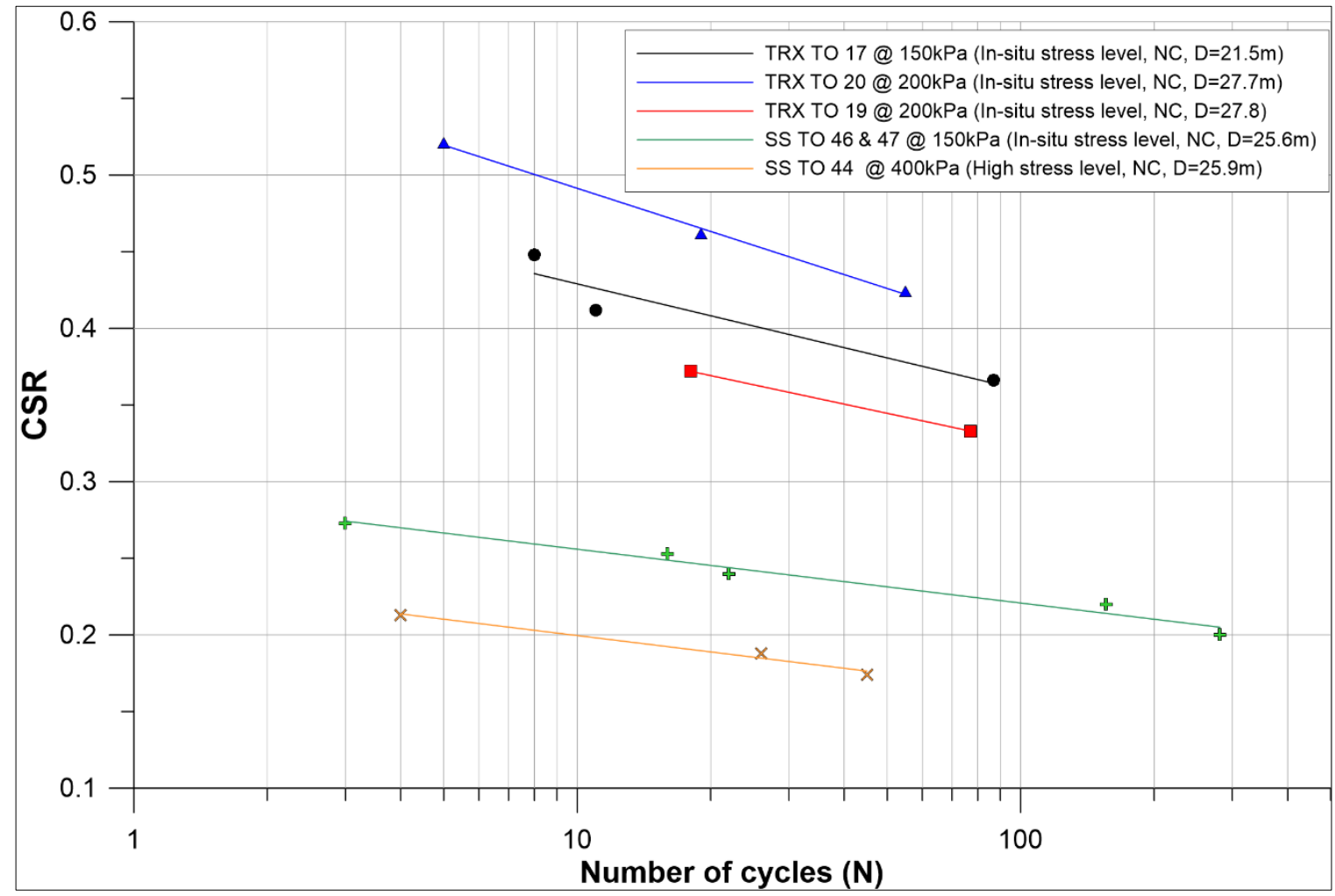

Figure 4-18 Simples shear and triaxial results comparison of Brackenridge sample in CSR form

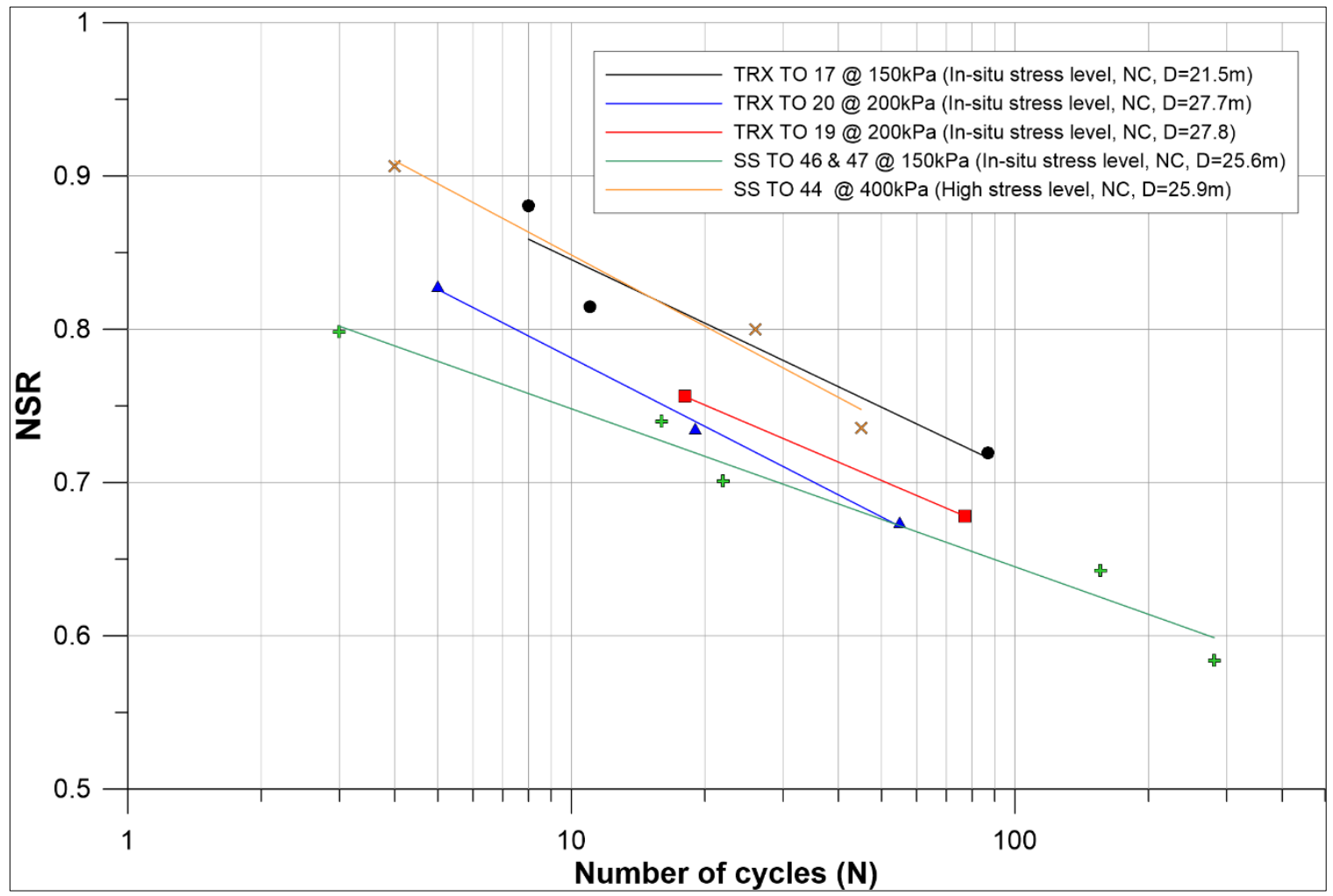

Figure 4-19 Simples shear and triaxial results comparison of Brackenridge sample in NSR form 


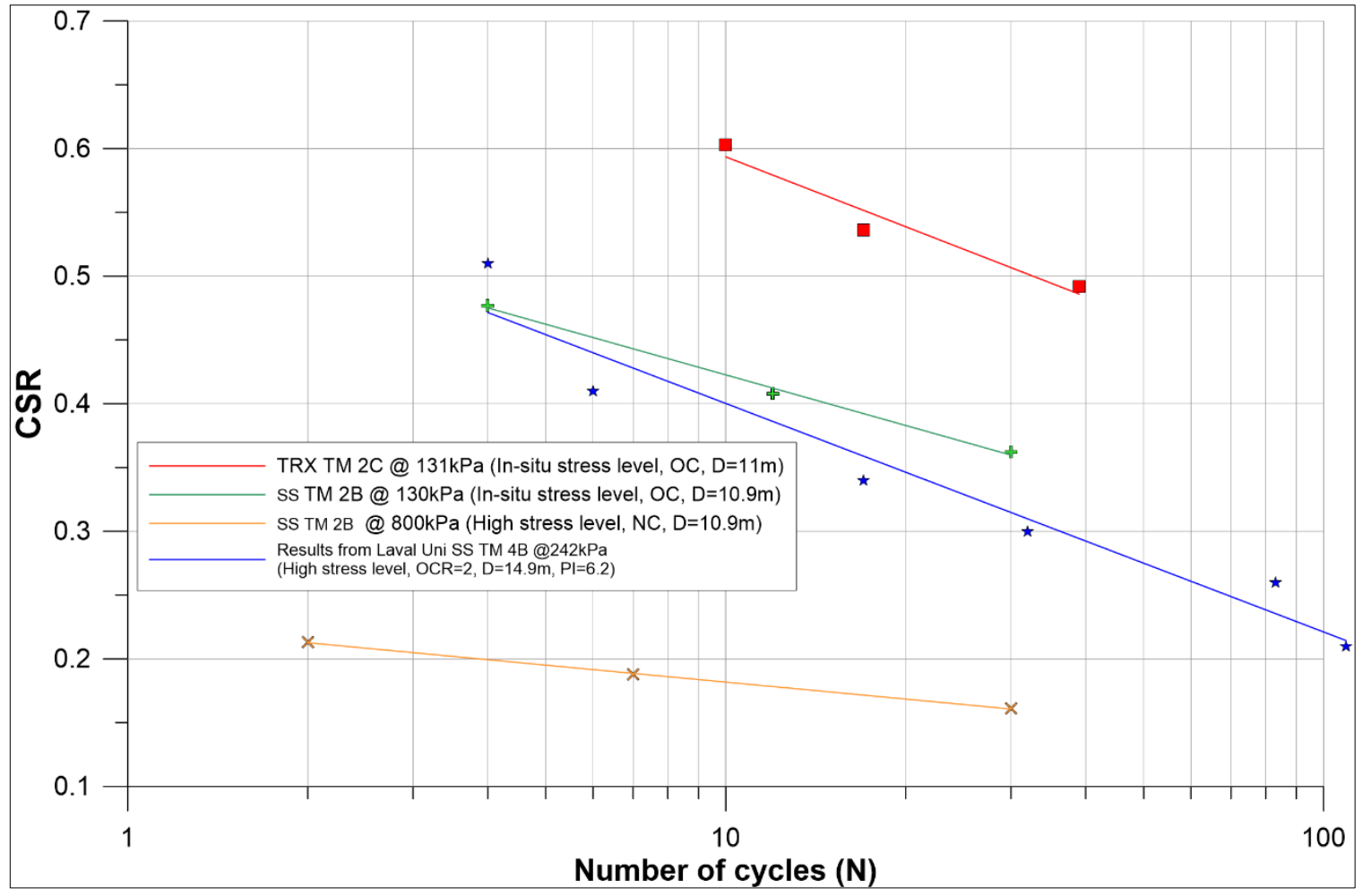

Figure 4-20 Simples shear and triaxial results comparison of Outardes-2 sample in CSR form

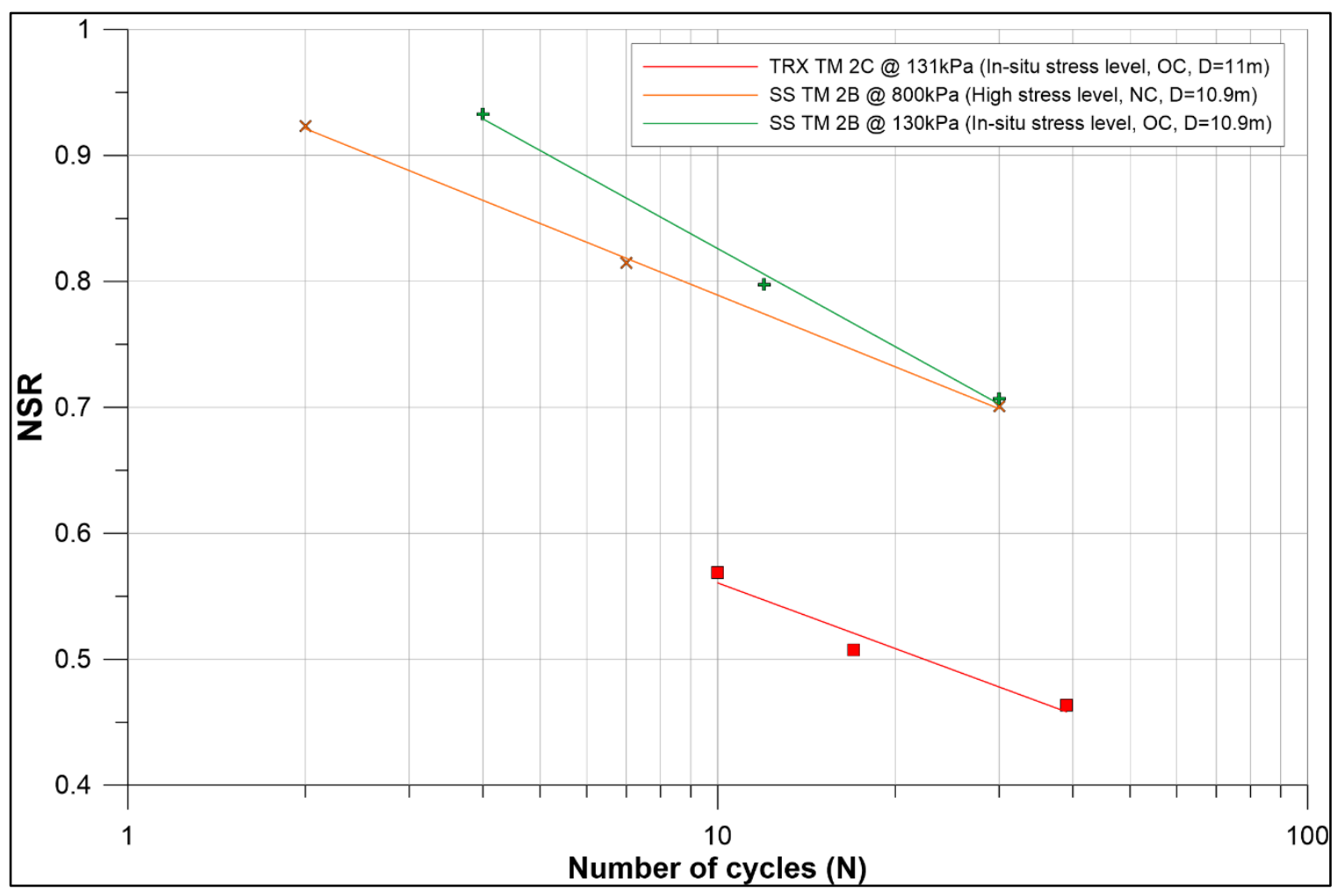

Figure 4-21 Simples shear and triaxial results comparison of Outardes-2 sample in NSR form 
Figures 4.18 and 4.19 show the comparison of simple shear and triaxial test results for Brackenridge samples in CSR and NSR forms. Test results for Outardes-2 clay have been compared in Figures 4.20 and 4.21. From the above plots, it can be observed that the cyclic resistance of a clay, expressed in terms of CSR, is significantly higher in triaxial than in simple shear. Figure 4.20 compares the cyclic simple shear and triaxial response of Outardes-2 clay $(z \approx 11 m)$. When comparing the samples consolidated to in-situ vertical stress $(131 \mathrm{kPa}$ with an $O C R=3.1)$ prior to cyclic shear, the resistance measured from cyclic triaxial tests in terms of CSR is consistently larger. A sample subject to a CSR of about 0.48 liquefies in 4 cycles in simple shear, but the same CSR in triaxial loading requires close to 40 cycles for liquefaction. This data yields a value of $C R R_{10, S S}=0.42$ and $C R R_{10, T X}=0.60$. Such differences in the cyclic strength of soils occur on account of the loading mode effects, and have been reported by several researchers in the literature for sands (e.g. Seed and Peacock, 1971; Kramer, 1996; Vaid and Sivathayalan, 1996). Similar results were also observed for the Breckenridge samples (Figure 4.19).

It is well known that the simple shear and triaxial tests impose different loading conditions on the sample. Simple shear loading condition is a close representation of the actual soil loading condition during an earthquake. Therefore, the cyclic resistance ratio obtained from triaxial tests is often multiplied by a factor, $C_{r}$, to use for design purposes. Seed and Peacock (1971) recommended a value of 0.6 for $C_{r}$. In the normalized stress ratio (NSR) comparison, the Brackenridge samples fall in a narrow band in both simple shear and triaxial tests and show a very similar pattern. However, the NSR results for the Ourtardes-2 samples are quite different for simple shear and triaxial tests. 


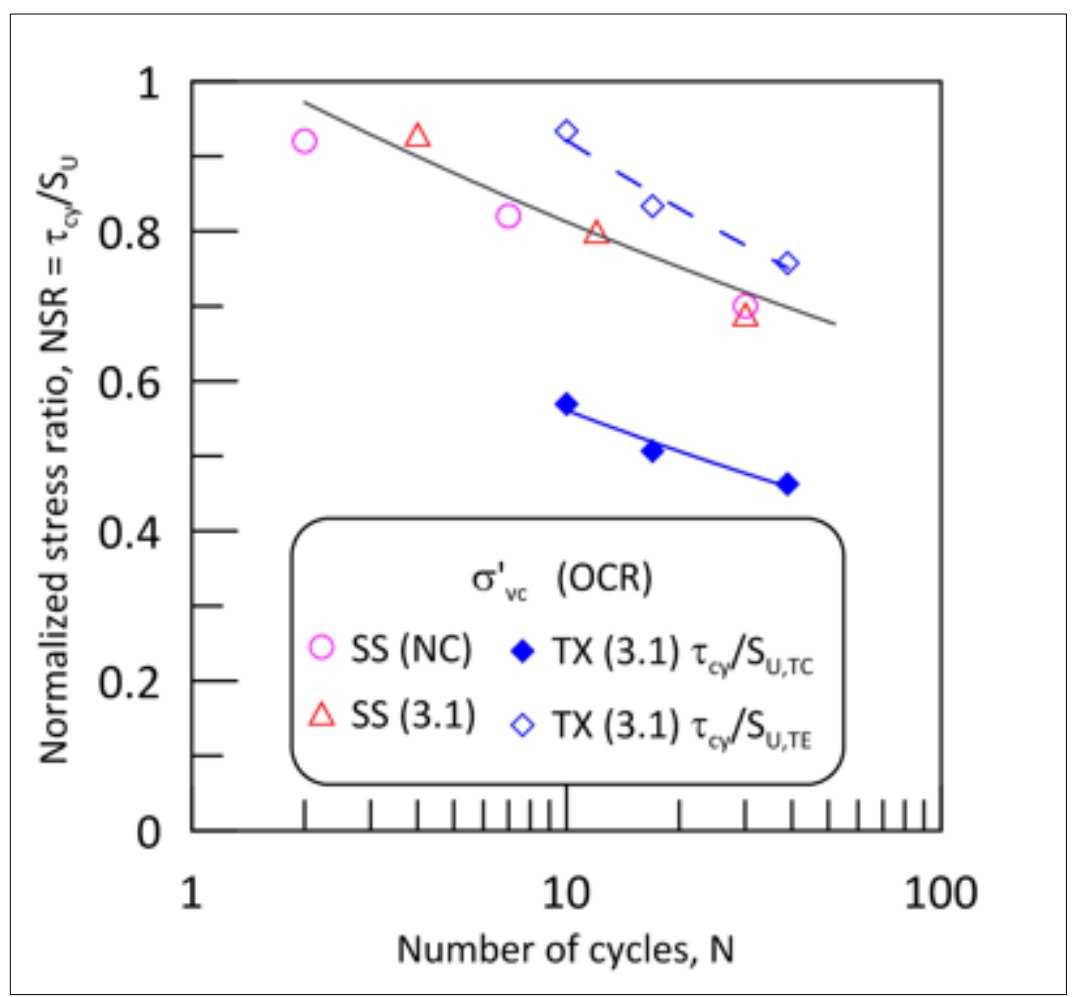

Figure 4-22 Effect of loading mode on NSR comparison of Outardes-2 clay

It is postulated the reason for such differences is possibly the uncertainty associated with the "undrained strength" in triaxial tests. There is no unique undrained shear strength $S_{u}$ value corresponding to cyclic triaxial tests (on isotopically consolidated specimens) for a given material as both compression and extension modes are activated during each half cycle. The Outardes-2 clay samples consolidated to in-situ stress levels at comparable OCR realized a normalized strength ratio of 0.73 in triaxial compression, but only 0.42 in triaxial extension (Blanchette, 2016). The cyclic resistance in terms of $\operatorname{NSR}\left(=\tau_{c y} / S_{u}\right)$ is therefore represented using two possible forms in Figure 4.22. The closed symbols and the solid line correspond to NSR value normalized using the undrained shear strength measured in triaxial compression tests $\left(N S R_{C}=\tau_{c y} / S_{U, T C}\right)$. The open symbols and the dashed line correspond to NSR computed using the undrained 
shear strength under triaxial extension $\left(N S R_{E}=\tau_{c y} / S_{U, T E}\right)$. Since the triaxial extension tests were not conducted in this research, relevant data from Blanchette (2016) was used to estimate the $S_{U, T E}$ and hence the value of $N S R_{E}$. The NSR values normalized using $S_{U, T E}$ are closer to the NSR in simple shear.

While the strain development during cyclic loading was fairly symmetric in the simple shear test, a clear bias toward the extension direction was present in all cyclic triaxial tests. The failure of sample always occurred in the extension mode, and was often associated with necking of the specimen. This is partly a reflection of the stress path dependent behavior noted in the monotonic tests. Since the failure during cyclic triaxial loading always occurred in the extension mode in these tests, the $N S R_{E}$ might be a more appropriate indicator of the cyclic strength of the material. However, sufficient attention has not been paid to this issue in the literature, thereby causing uncertainty.

\subsubsection{Post cyclic behavior}

It is of immense interest to engineers to study the post liquefaction behavior of soils as it enables a better understanding of the consequences of soil liquefaction. In general, soil follows its lowered original monotonic strength envelope during the postliquefaction static loading. Different studies from literature shows that clayey soils regain significant undrained strength (more than $80 \%$ ) post cyclic loading and many factors, including the characteristics of clay, cyclic stress and strain level, number of loading cycles, developed pore water pressure, etc. control this behaviour (Thiers and Seed, 1969; Anderson and Richart Jr, 1976; Boulanger and Idriss, 2004).

The Breckenridge samples subjected to cyclic tests failed suddenly with a very 
large strain and therefore, no post cyclic tests could be conducted on these samples. However, post cyclic tests were performed on the Outardes-2 samples with a static axial strain rate of 5\% per hour. The stress controlled cyclic tests were terminated at an axial strain of $2.5 \%$ and the post cyclic static loading was started immediately.

Figure 4.23 compares the monotonic, cyclic and post cyclic test results of the Outardes-2 sample consolidated at in-situ pressure (131 kPa). During the cyclic loading, a deviatoric stress with a CSR of 0.6 was applied and the sample failed in the extension side at $10^{\text {th }}$ loading cycles. Post-cyclic monotonic stress-strain curve shows a similar behavior to the original monotonic loading but with a lower magnitude (Figure 4.23). During the original monotonic loading, the shear strength of sample sharply increased and reached a peak value of $139.2 \mathrm{kPa}$ at around $2.5 \%$ of axial strain, whereas the postcyclic strength slowly reached $79 \%$ of its monotonic strength $(109.6 \mathrm{kPa})$ at around $5 \%$ of axial strain.

Table 4-2 Post cyclic results of Outardes-2 clay

\begin{tabular}{|c|c|c|c|c|c|c|}
\hline \multirow{2}{*}{ Test ID } & \multirow{2}{*}{$\sigma_{c}^{\prime}(\mathbf{k P a})$} & \multicolumn{3}{|c|}{ Cyclic Loading } & \multicolumn{2}{c|}{ Post cyclic } \\
\cline { 3 - 7 } & & $\mathbf{C S R}$ & $\mathbf{N}$ & $\boldsymbol{\varepsilon}_{\boldsymbol{a}, \boldsymbol{m a x}}$ & $\mathbf{S}_{\text {peak }}(\mathbf{k P a})$ & $\mathbf{S}_{\text {peak }} / \mathbf{S}_{\mathbf{u}}$ \\
\hline CYC-09 & 131 & 0.492 & 39 & $-2.60 \%$ & 125 & 0.90 \\
& & & & & & \\
\hline CYC-10 & 131 & 0.536 & 17 & $-2.54 \%$ & 106.9 & 0.77 \\
\hline CYC-11 & 131 & 0.603 & 10 & $-2.56 \%$ & 109.6 & 0.79 \\
\hline
\end{tabular}

Figure 4.24 shows the normalized stress-strain, pore water pressure generation and the stress paths from post-cyclic test of Outardes-2 clay sample (CYC 11). A negative excess pore water pressure was built up during the initial loading followed by a positive excess pore water pressure which was built slowly thereafter. The results of all 
three post-cyclic results are shown in table 4.2. The available post cyclic test results are very limited hense no specific trend line obserbed.

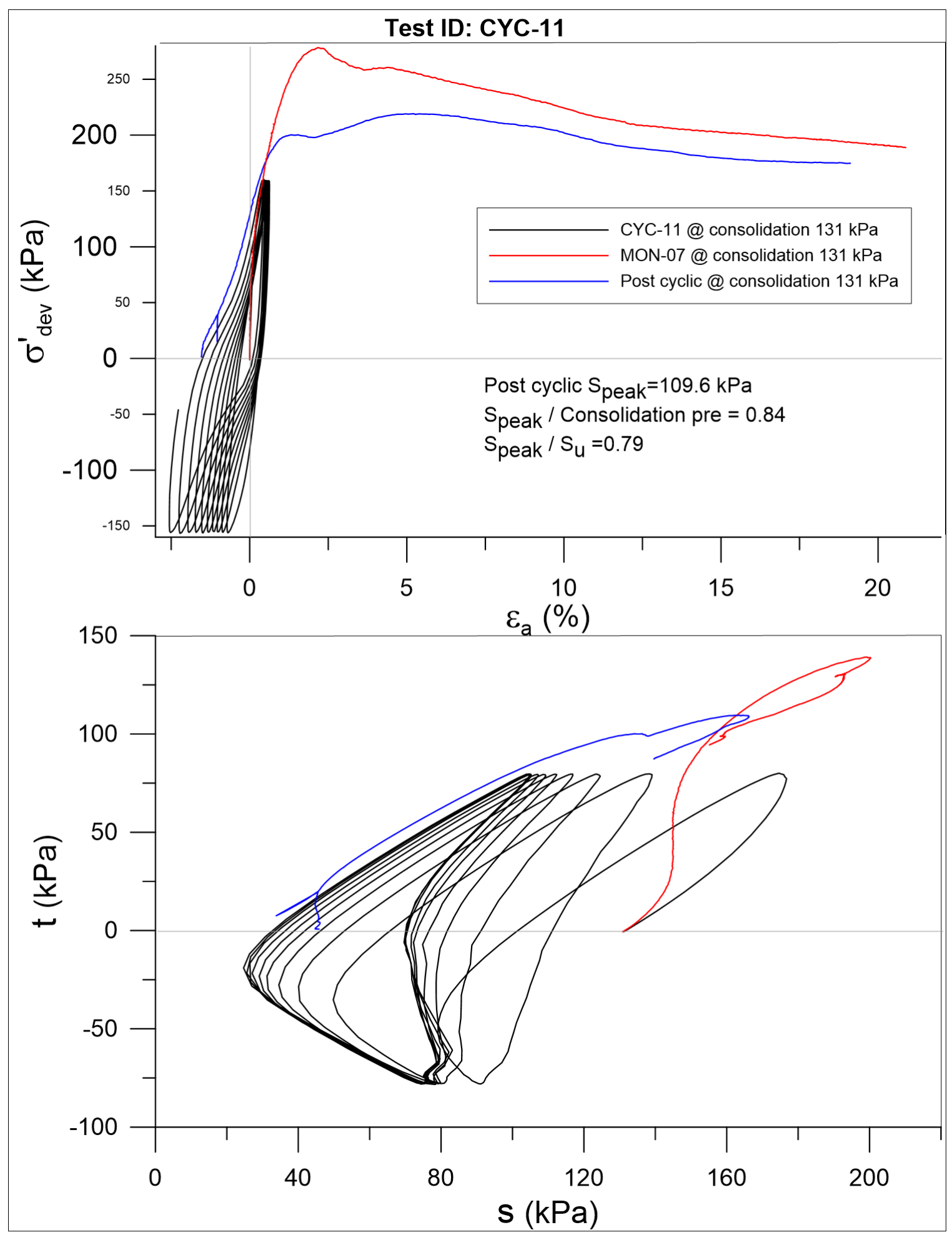

Figure 4-23 Comparison of monotonic, cyclic and post-cyclic behavior of Outardes-2 clay 


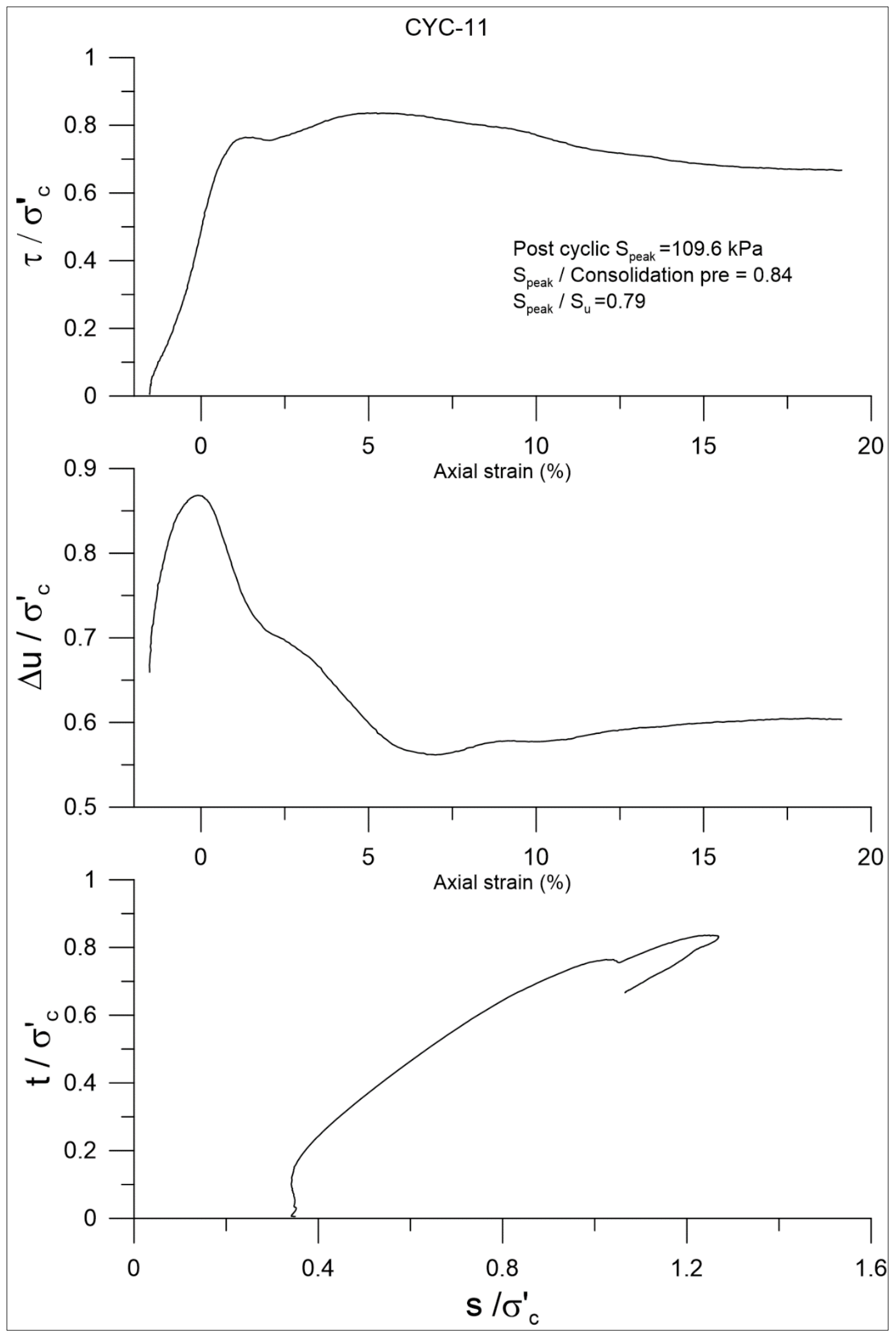

Figure 4-24 Normalized post-cyclic behavior Outardes-2 clay 


\section{Dynamic behavior of Leda clay and sands}

\subsection{Introduction}

The principal objective of this research study is to propose site specific modulus and damping curves for sensitive Leda clays under triaxial loading condition. It is necessary to measure the very small levels of strain and stress for a reliable estimation of modulus and damping values in soil. Therefore, Carleton triaxial device was enhanced to accurately measure very low level of strain and stress as mentioned in Chapter 3.

Characteristics of secant shear modulus $\left(G_{s}\right)$, shear modulus reduction $\left(G_{s} / G_{\max }\right)$ and damping ratio $(\xi)$ of sensitive Lada clays obtained from Breckenridge and Outardes2 at different stress conditions are presented in this chapter. In addition, similar dynamic properties of Fraser River sand and Ottawa sand also have been presented. The testing methods which are adopted in this study to establish dynamic properties of clay and sands are discussed in the first part of this chapter. Then the modulus and damping behavior of sensitive Leda clay at different consolidation levels are presented in the second part. Finally, dynamic properties of Fraser River sand and Ottawa sand at different stress and relative density states are discussed.

\subsection{Testing method}

Modulus and damping tests on clay are associated with relatively small levels of stress, and strain development within the specimen. The variations in the measured modulus and damping between virgin specimens, and specimens subjected to less than 1\% strain amplitude have been found to be insignificant in Leda clay (Theenathayarl, 2015; Thirugnanasampanther, 2016). The in-situ structure of the Leda clay presumably is 
not disturbed at small strain levels sufficiently to impact the response during subsequent stages. As a result, multi-stage testing was undertaken when possible. Further this testing method could eliminate the uncertainty caused by natural heterogeneity among the different specimens and sampling constraints. Additionally, a multi-stage testing method requires fewer undisturbed clay samples than single stage test, and is cost effective. This effectiveness makes the method a preferred method, when possible, on clays in instances of limited undisturbed samples.

Multi stage stress controlled quasi-cyclic testing method was adopted in this research programme to study the modulus and damping behavior of sensitive Leda clay. The undisturbed clay specimen was first subjected a lower consolidation pressure and was put through several stress controlled quasi cyclic loading (with gradually increasing deviatoric stress amplitude) in undrained conditions. The deviatoric stresses were chosen to produce a range of cyclic strain in the specimen (targeted between $0.01 \%$ to $1 \%$ ). To avoid significant disturbance in the sample, the maximum axial strain was limited to $1 \%$ at each stage, and the number of loading cycles at each deviatoric stress level was limited to three cycles. Then the specimen was consolidated to a higher stress level and quasicyclic loading was repeated.

The reliability of multi stage stress controlled quasi-cyclic testing method was also analyzed under triaxial conditions, since the previous work by Theenathayarl (2015) and Thirugnanasampanther (2016) was conducted in simple shear. An undisturbed sample from Breckenridge (TO-24) was multi-stage-tested at consolidation pressure levels of $100 \mathrm{kPa}, 200 \mathrm{kPa}$, and finally at $400 \mathrm{kPa}$ (M\&D-3, Multi stage testing at 400 $\mathrm{kPa}$ consolidation). Then another fresh undisturbed sample was prepared from the same 
borehole block (TO-24) and was consolidated to $400 \mathrm{kPa}$ directly, and modulus damping measurements were made (M\&D-4). The secant shear modulus measured in these two tests is compared in Figure 5.1. The modulus values from both tests, M\&D-3 and M\&D-4 follow a very similar trend and they reveal that multi stage stress controlled quasi-cyclic testing method on sensitive Leda clay under triaxial conditions provides acceptable results.

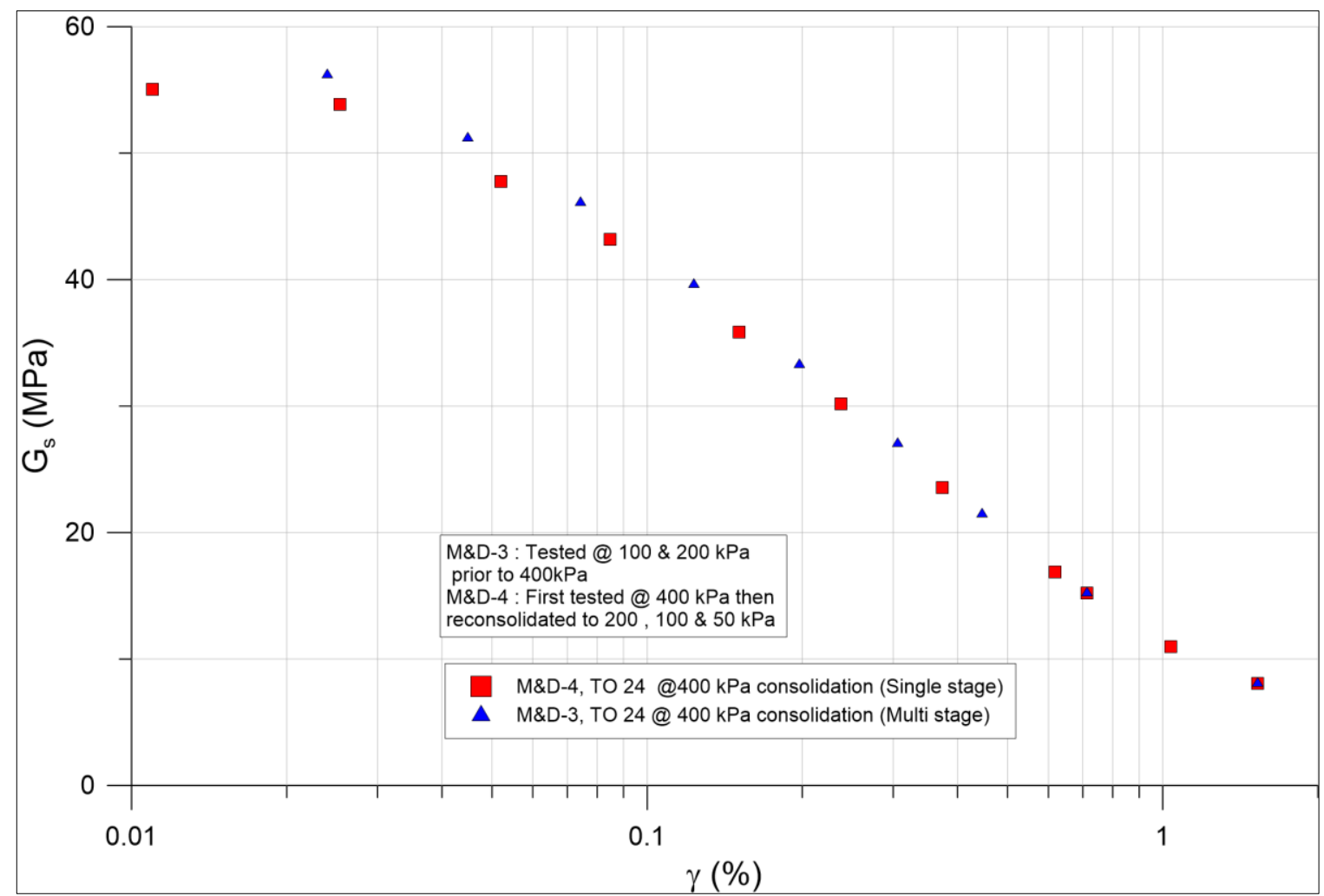

Figure 5-1 Single-stage and Multi-Stage Modulus comparison (M\&D-4 and M\&D-3)

Sand specimens were reconstituted by water pluviation method in this research. This enables replication of essentially identical samples at required target densities and thus single stage quasi-cyclic testing method was adopted to evaluate the dynamic behavior of sands. However, pore-water pressure generation during each quasi-cyclic loading is higher in sands, and thus the effective stress decreases with loading cycles. In 
order to minimize the effect of this, the sand specimens were re-consolidated to the initial consolidation stress after each stage. Through this approach, the effective stresses were maintained to the initial condition during each cyclic loading, but the specimen densified a little after each stage. It should be noted that the change in the density of the specimen was not significant at all. The maximum accumulated density change throughout the all stages of cyclic loadings was about $1 \%$. It confirms that the results of each quasi-cyclic loading can be used to study the modulus and damping behavior of sand effectively.

A typical modulus and damping test on sensitive Leda clay is shown in Figures 5.2 and 5.3. The undisturbed sample was collected from Breckenridge site (TO-24) and multi-stage-tested at $100 \mathrm{kPa}, 200 \mathrm{kPa}$, and finally at $400 \mathrm{kPa}$. The figures show corresponding quasi-cyclic tests at $400 \mathrm{kPa}, \mathrm{M} \& \mathrm{D}-3$. Figure 5.2 shows the application of cyclic stress, excess pore-water pressure generation and the gradual increase of axial strain with number of loading cycles. The stress-strain response of the clay and the stress path to the corresponding loading is shown in Figure 5.3. Three loading cycles were applied at each cyclic stress levels to minimize the uncertainties in measurements, especially at small strain levels. 


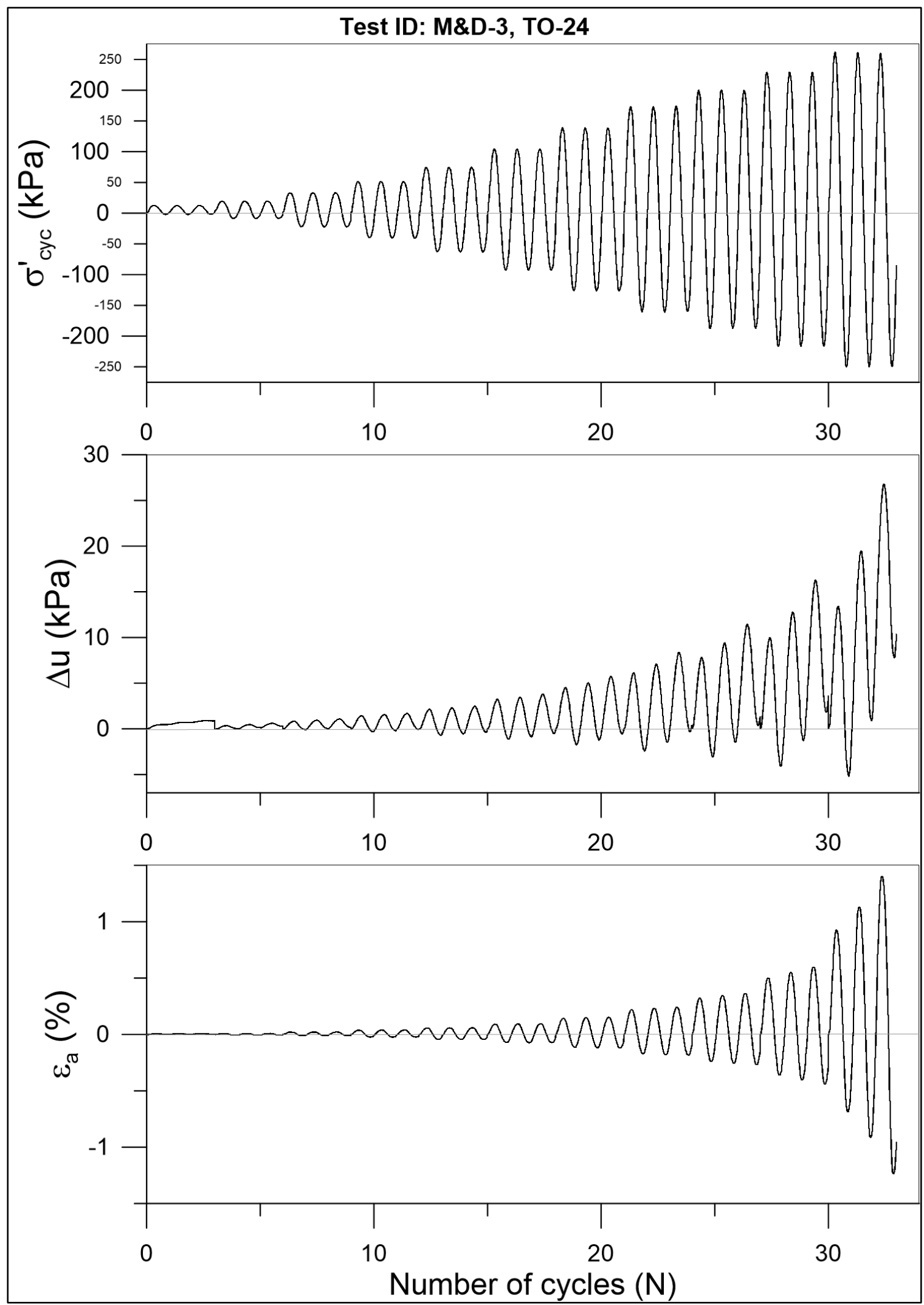

Figure 5-2 Typical behavior of Leda clay during quasi-cyclic loading (deviatoric stress, pore pressure and axial strain with $\mathbf{N}$ ) 


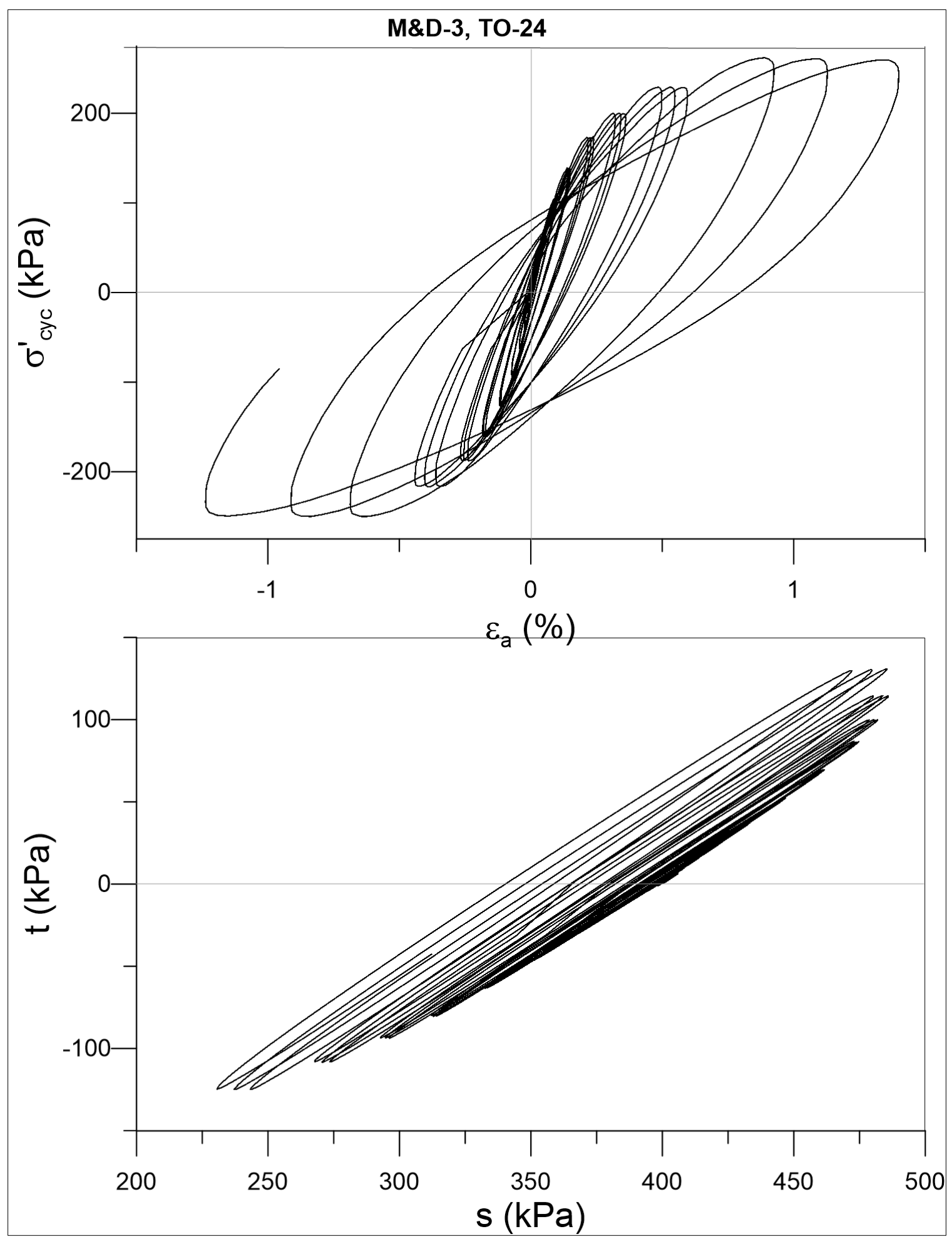

Figure 5-3 Typical behavior of Leda clay during quasi-cyclic loading (Stress-Strain response and stress path) 


\subsection{Modulus and Damping characteristics of Leda clay}

A series of multi stage stress controlled quasi-cyclic test were conducted on the undisturbed samples obtained from Breckenridge and Outardes- 2 at different consolidation pressures. All the modulus and damping tests on sensitive clay were carried out at an isotopically-consolidated sample. Modulus and damping values at a corresponding strain levels were calculated from the stress-strain loops, which is similar to the loops shown in Figure 5.3.

\subsubsection{Calculation of the secant shear modulus $\left(G_{s}\right)$ and damping ratio $(\xi)$}

Three complete stress-controlled cyclic loading cycles were applied to the sample at each level of cyclic stress. Out of these three-obtained stress-strain loops, the second cycle provides a complete hysteresis loop at the corresponding stress level and was chosen to estimate secant shear modulus and damping ratio for the particular loading condition. A typical set of selected stress-strain loops to calculate modulus and damping values for the Breckenridge sample at $400 \mathrm{kPa}$ consolidation pressure, M\&D-3, is presented in Figure 5.4. Similarly, stress-strain loops for each sample at each consolidation stress level were plotted in order to calculate corresponding modulus and damping values to the respective strain amplitudes. It should be noted that stress-strain loops presented in Figure 5.4 are in terms of cyclic deviatoric stress and axial strain. The elastic modulus of each test was calculated by measuring the slope of the hysteresis loop (Deviatoric stress/axial strain) and then converted to a corresponding secant shear modulus by dividing it by 3 . It can be observed in the Figure 5.4 that the elastic modulus (slope of stress-strain curve) gradually decreases with increasing strain level. 


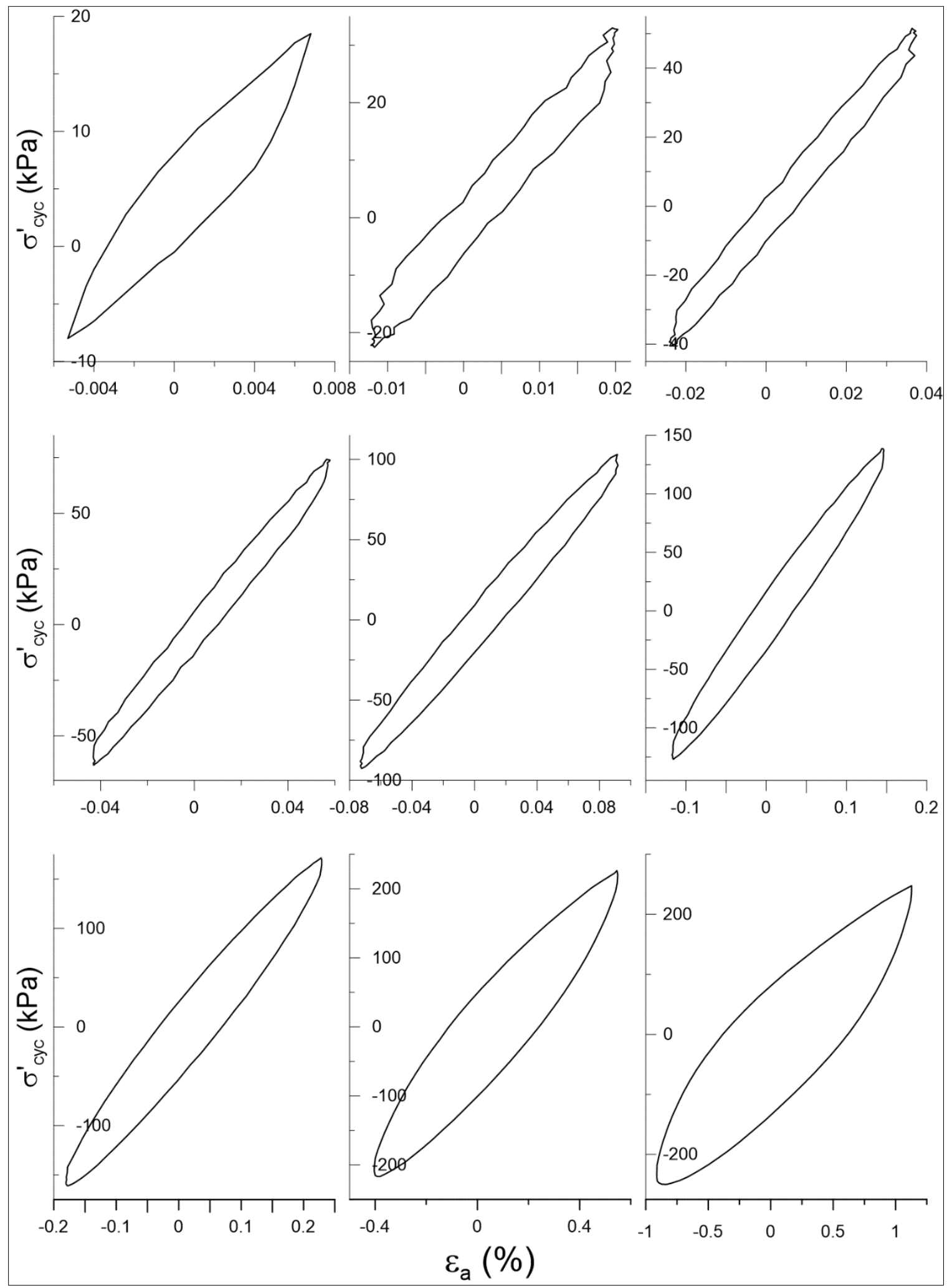

Figure 5-4 Stress-strain loops obtained from stress controlled quasi-cyclic loading (M\&D-3, Breckenridge sample consolidated at $400 \mathrm{kPa}$ ) 
The damping ratio to respective strain was calculated based on the total area enclosed by the loop. But the friction in the loading system provides some damping in addition to the actual energy absorbed by the soil. While the effect of the frictional damping is quite insignificant at large strains, it could alter the damping values significantly at the small strain levels. Therefore, the area which was subjected to the friction of the system was calculated by loading the system without soil specimen as indicated in Figure 5.5, and then subtracted from the total area of hysteresis loop to calculate actual damping value of the soil.

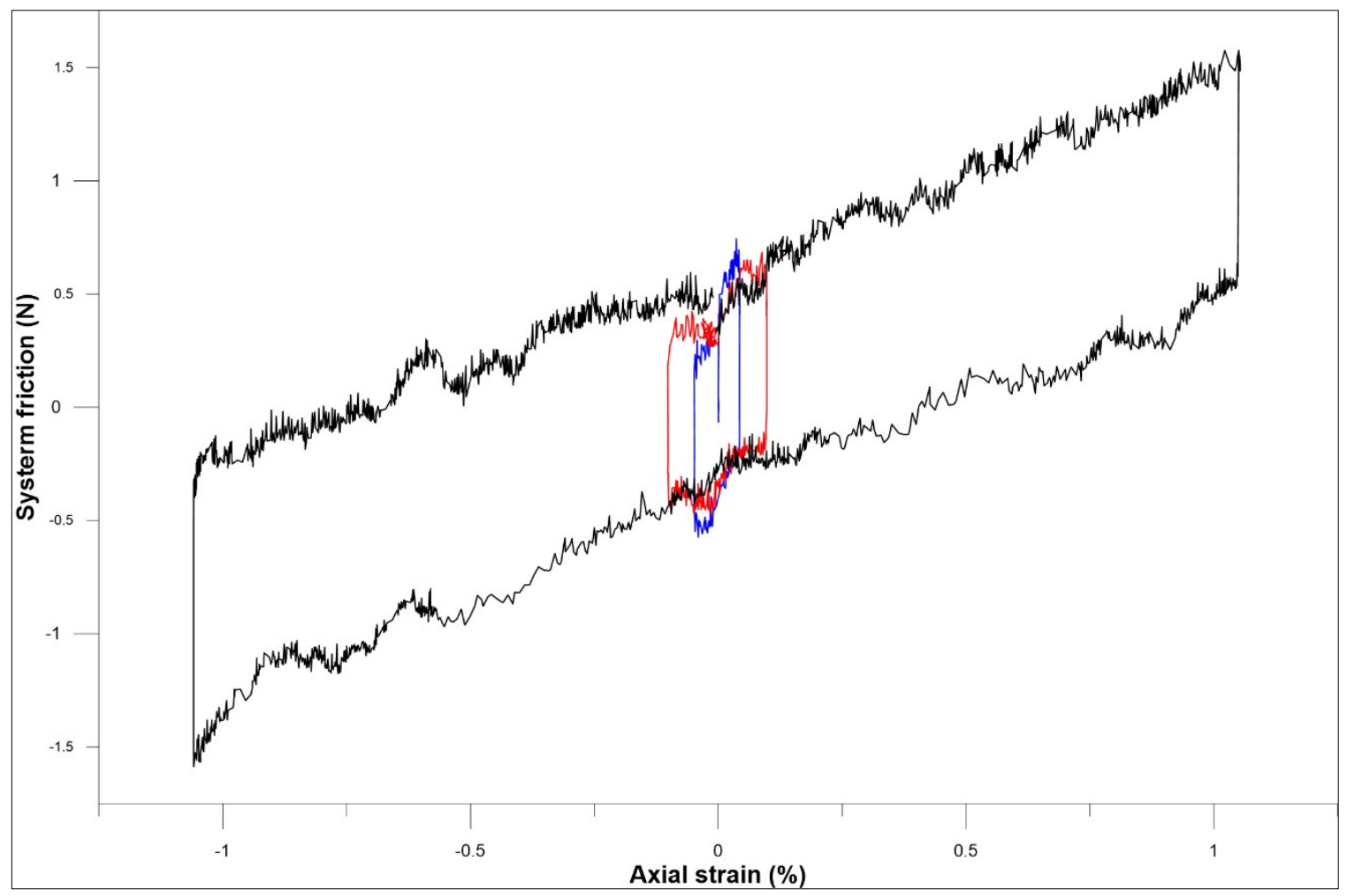

Figure 5-5 The measured friction in the system without soil specimen to correct the damping area

\subsubsection{Estimation of maximum shear modulus $\left(G_{\max }\right)$}

The maximum shear modulus $\left(\mathrm{G}_{\max }\right)$ is the peak value of secant shear modulus (technically tangent modulus, since strains are very small), and it is an important soil 
dynamic property for a soil response analysis. Modulus reduction curves are developed by normalizing the secant shear modulus $\left(\mathrm{G}_{\mathrm{s}}\right)$ by $\mathrm{G}_{\max }$. Maximum shear modulus value is measured at very low shear strain levels (at $\gamma<0.001 \%$ ); typically using resonant column or bender element tests that are capable of accurately measuring the modulus at such small shear strain levels. The resolution of the triaxial device used in this study is not sufficient to precisely determine maximum shear modulus. Therefore, a method proposed by Theenathayarl (2015), based on an evaluation of the data in the literature, was adopted in this research to estimate maximum shear modulus value from the available secant shear modulus values. The measured secant shear modulus value at $0.01 \%$ of shear strain was assumed to be equal to $85 \%$ of the maximum shear modulus $\left(G_{S_{(\gamma=0.01 \%)}}=0.85 * G_{\max }\right)$.

The estimated maximum shear modulus values are plotted with effective consolidation pressure for each tested sample (Figure 5.6). $\mathrm{G}_{\max }$ increases significantly with increasing consolidation pressure. Seed and Idriss (1986) drew a correlation between $\mathrm{G}_{\max }$ and effective consolidation pressure $\left(\sigma_{c}^{\prime}\right)$ as follows and proposed a value about 0.5 for the exponent ' $m$ '.

$$
G_{\max }=k *\left(\sigma_{c}^{\prime}\right)^{m}
$$

The presented plots (5.6) shows $m$ values of $0.68,0.35$ and 0.53 for Breckenridge samples TO-24-1, TO-24-2 and Outardes-2 TM 2C clays respectively. It should be noted that apart from effective consolidation pressure, OCR also affects the value of maximum shear modulus and those both impacts are combined in Figure 5.6. 


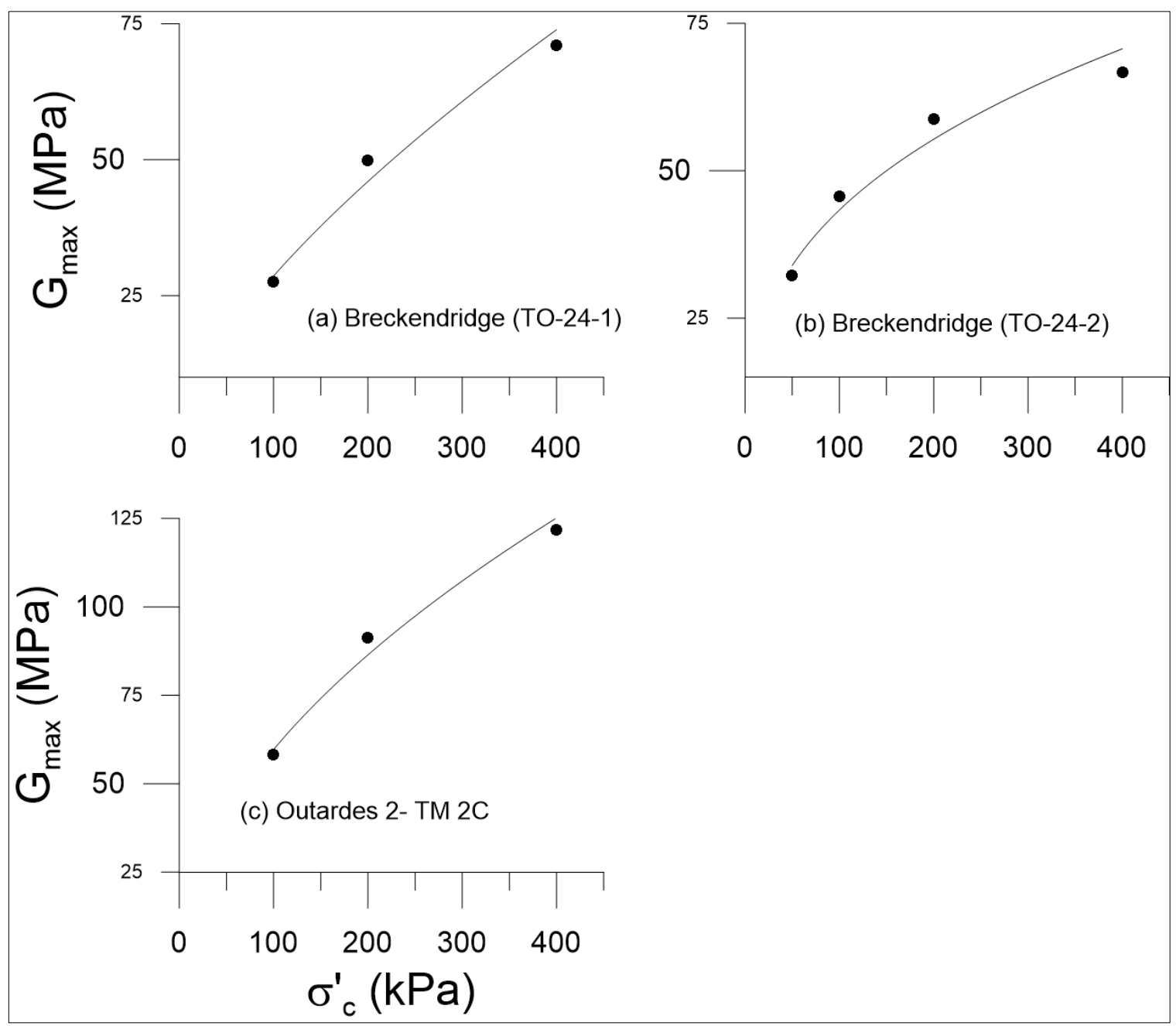

Figure 5-6 Variation of Maximum shear modulus with effective consolidation pressure

\subsection{Modulus and damping of sensitive clays}

The modulus and damping characteristics of Breckenridge clay was assessed by testing two undisturbed specimens under multi staged stress controlled quasi-cyclic loading. Data were gathered at 100, 200 and $400 \mathrm{kPa}$ stress levels. Since the preconsolidation pressure of this specimen was approximately $125 \mathrm{kPa}$, the first case represents a test at $\mathrm{OCR}=1.25$, and the latter two $\mathrm{NC}$ clay. The variation of secant shear modulus $\left(\mathrm{G}_{\mathrm{s}}\right)$, normalized shear modulus $\left(\mathrm{G}_{\mathrm{s}} / \mathrm{G}_{\max }\right)$ and the damping ratio $(\xi)$ with shear strain values $(\gamma)$ are presented in Figure 5.7. 
The second specimen from Breckenridge (TO-24-2) was first consolidated to 400 $\mathrm{kPa}$ stress level and quasi cyclically loaded at normally consolidated stage. Then it was reconsolidated to $200 \mathrm{kPa}, 100 \mathrm{kPa}$ and finally $50 \mathrm{kPa}$ consolidation pressures in the decreasing order and quasi cyclically loaded at each stage. This was intended to assess the effects of OCR. The variation of the secant shear modulus $\left(\mathrm{G}_{\mathrm{s}}\right)$, normalized shear modulus $\left(\mathrm{G}_{\mathrm{s}} / \mathrm{G}_{\max }\right)$ and the damping ratio $(\xi)$ with shear strain $(\gamma)$ are given in Figure 5.8.

A sample from Outardes-2 site (TM-2C) was quasi cyclically loaded at 100, 200 and $400 \mathrm{kPa}$ consolidation pressures first, and then re-tested at $200 \mathrm{kPa}$ stress level. The modulus and damping characteristics of this specimen is presented in Figure 5.9.

Figure 5.7, 5.8 and 5.9 demonstrate the general trend of modulus and damping characteristics of sensitive Leda clays. Secant shear modulus and normalized shear modulus values are decreasing with increasing shear strain level while damping ratio increases with shear strain. Secant shear modulus significantly increases with increasing consolidation pressures but the effect of consolidation pressure is not dominant in normalized shear modulus. 


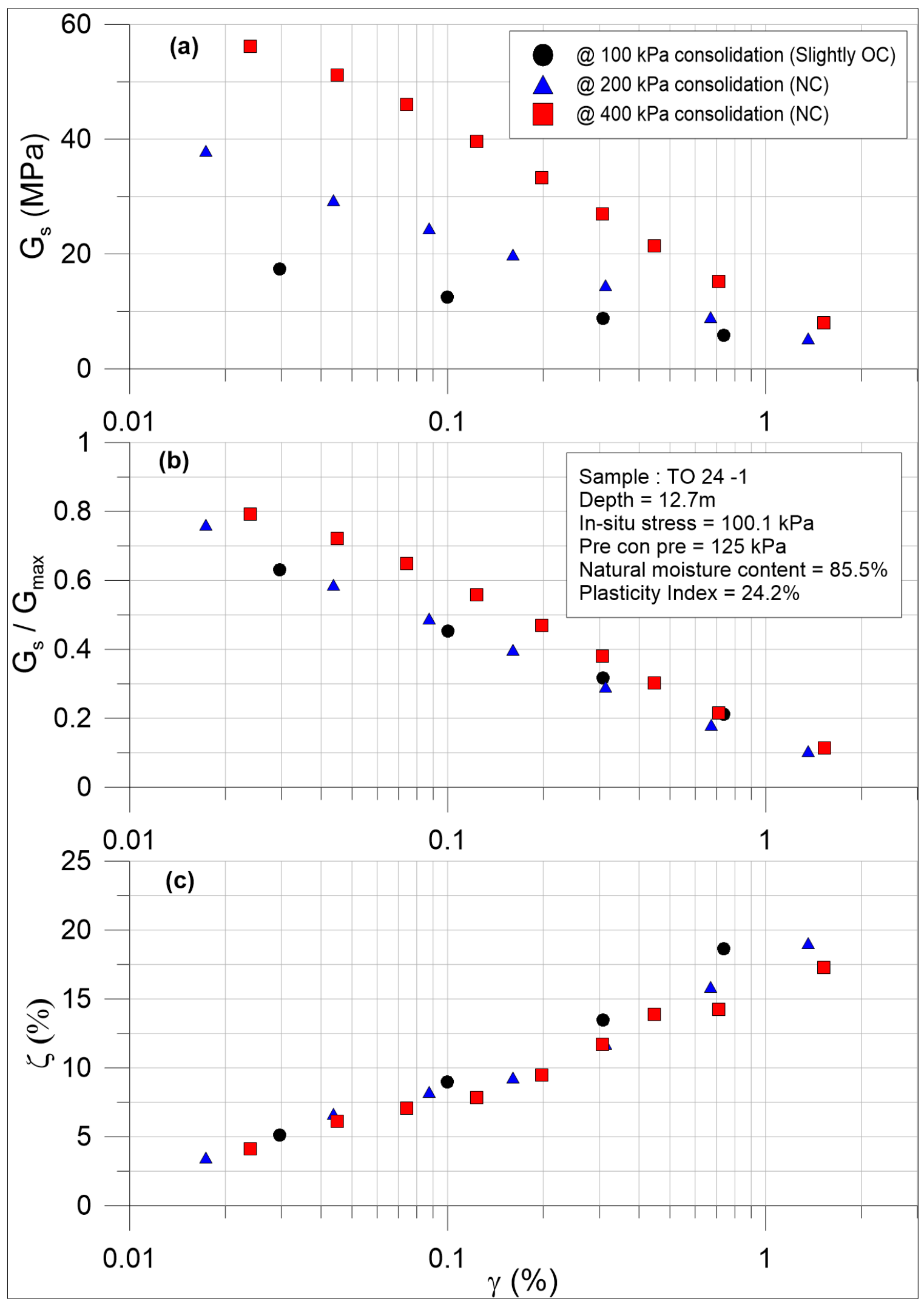

Figure 5-7 (a)-Secant shear modulus, (b)- normalized shear modulus and (c)- damping ratio variation of Breckenridge sample (TO-24-1) with shear strain 


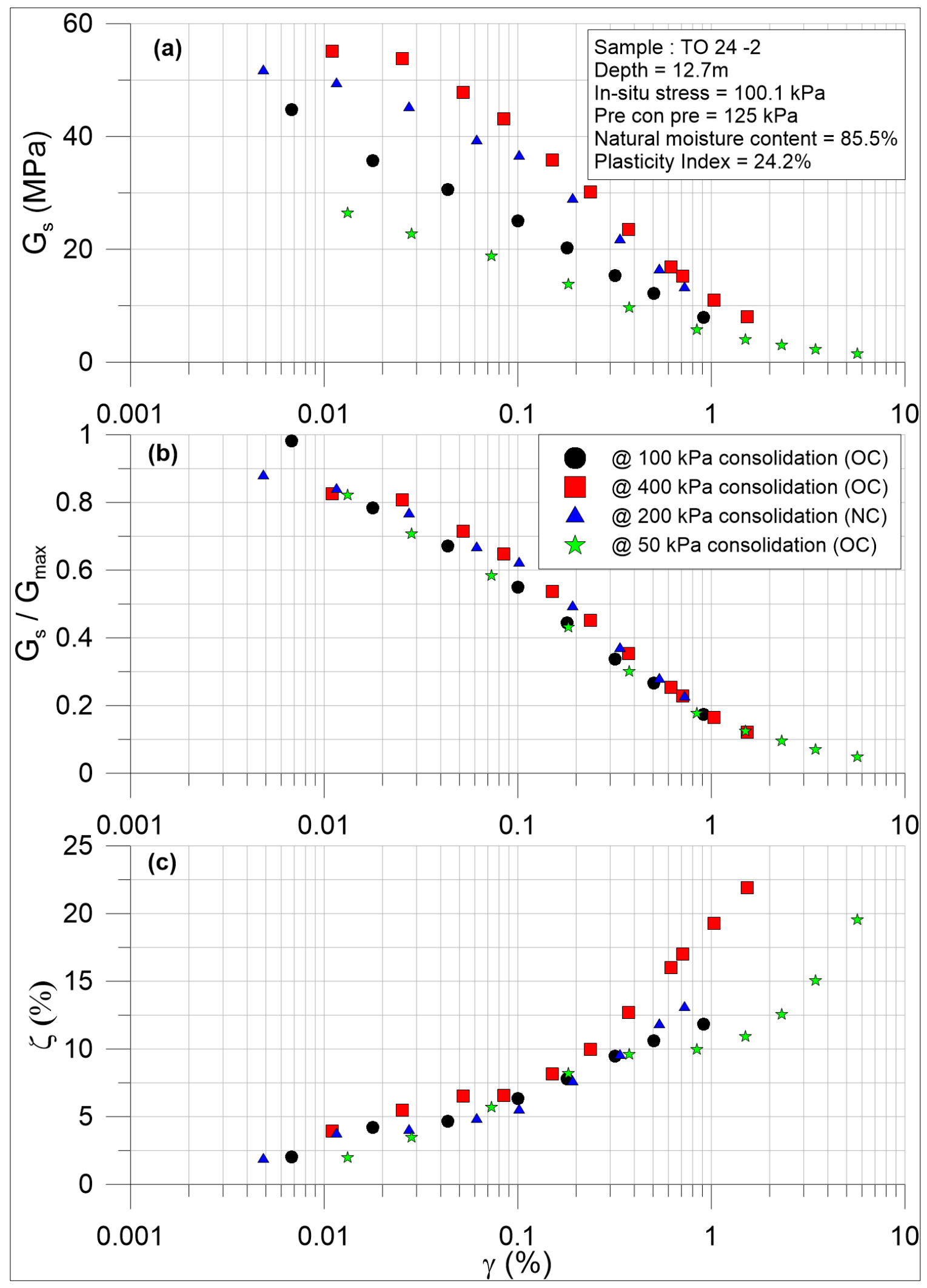

Figure 5-8 (a)-Secant shear modulus, (b)- normalized shear modulus and (c)- damping ratio variation of Breckenridge sample (TO-24-2) with shear strain 

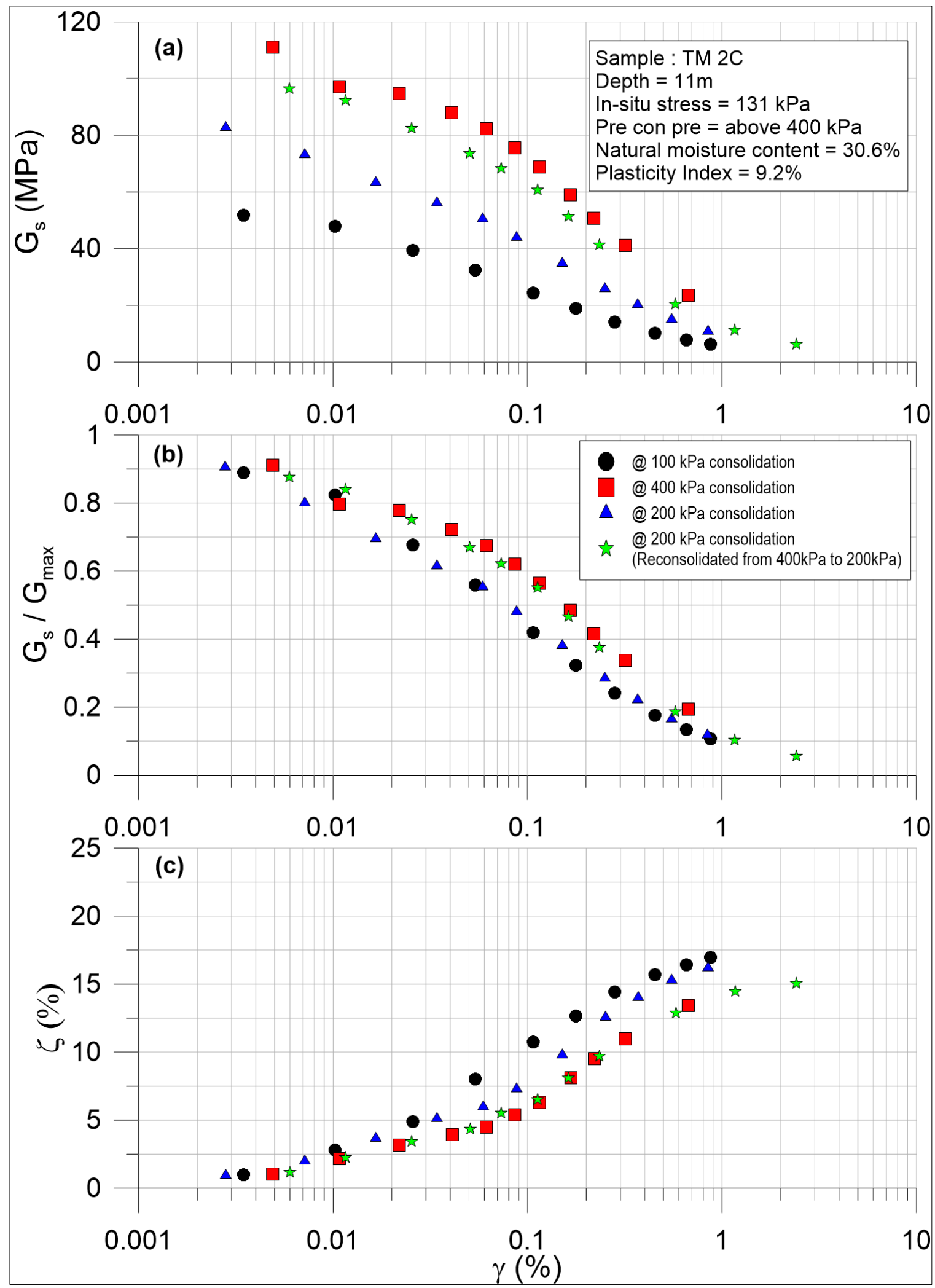

Figure 5-9 (a)-Secant shear modulus, (b)- normalized shear modulus and (c)- damping ratio variation of Outardes-2 sample (TM-2C) with shear strain 
The secant shear modulus values of both Breckenridge specimens (TO-24-1 \& TO-24-2) at $400 \mathrm{kPa}$ consolidation pressure are compared previously in Figure 5.1. Those modulus values follow very similar trends which reveals that multi stage quasi cyclic testing method produce reliable results in sensitive clays.

Figures 5.7 (a), 5.8 (a) and 5.9 (a) indicate that consolidation pressure significantly influences the secant shear modulus of sensitive clay. For example, in Breckenridge sample TO-24-2 at shear stain of $0.01 \%$, specimen consolidated at $400 \mathrm{kPa}$ shows the highest modulus value of $56 \mathrm{MPa}$ and it reduces to $50 \mathrm{MPa}, 38.7 \mathrm{MPa}$ and 27.3 $\mathrm{MPa}$ at the consolidation pressures of $200 \mathrm{kPa}, 100 \mathrm{kPa}$ and $50 \mathrm{kPa}$ respectively. Outardes-2 clay has a higher secant shear modulus than Breckenridge clay. At $400 \mathrm{kPa}$ consolidation stress and $0.01 \%$ shear stain level, Breckenridge specimen shows $56 \mathrm{MPa}$ of secant shear modulus, but Outardes-2 sample shows 103.5 MPa. Also, it should be noted that natural moisture content and plasticity index of Outardes-2 sample are lower than that of Breckenridge samples. The damping ratio variation is more scattered between different consolidation stress levels within each specimen.

The effect of over consolidation ratio in the secant shear modulus is studied by comparing test results from Breckenridge specimens at the same consolidation pressures. The graphs in Figure 5.10 point to the influence of OCR at the $100 \mathrm{kPa}$ and $200 \mathrm{kPa}$ consolidation levels. Since both specimens were taken from same sample block (TO-24), they are expected to be physically similar (clay minerals, natural moisture content, plasticity index etc.) and were tested under the same consolidation pressure but at different OCR, Figure 5.10 reveals that secant shear modulus is higher for the specimen with higher OCR values. At $200 \mathrm{kPa}$ consolidation pressure, the specimen tested at OCR 
2 shows a shear modulus of $50 \mathrm{MPa}$ at $0.01 \%$ shear strain while the OCR 1 specimen shows 42.4 MPa. Similarly, at $100 \mathrm{kPa}$ consolidation, specimen with OCR 4 and 1.25 show $38.7 \mathrm{MPa}$ and $23.3 \mathrm{MPa}$ of shear modulus respectively at $0.01 \%$ of shear strain.

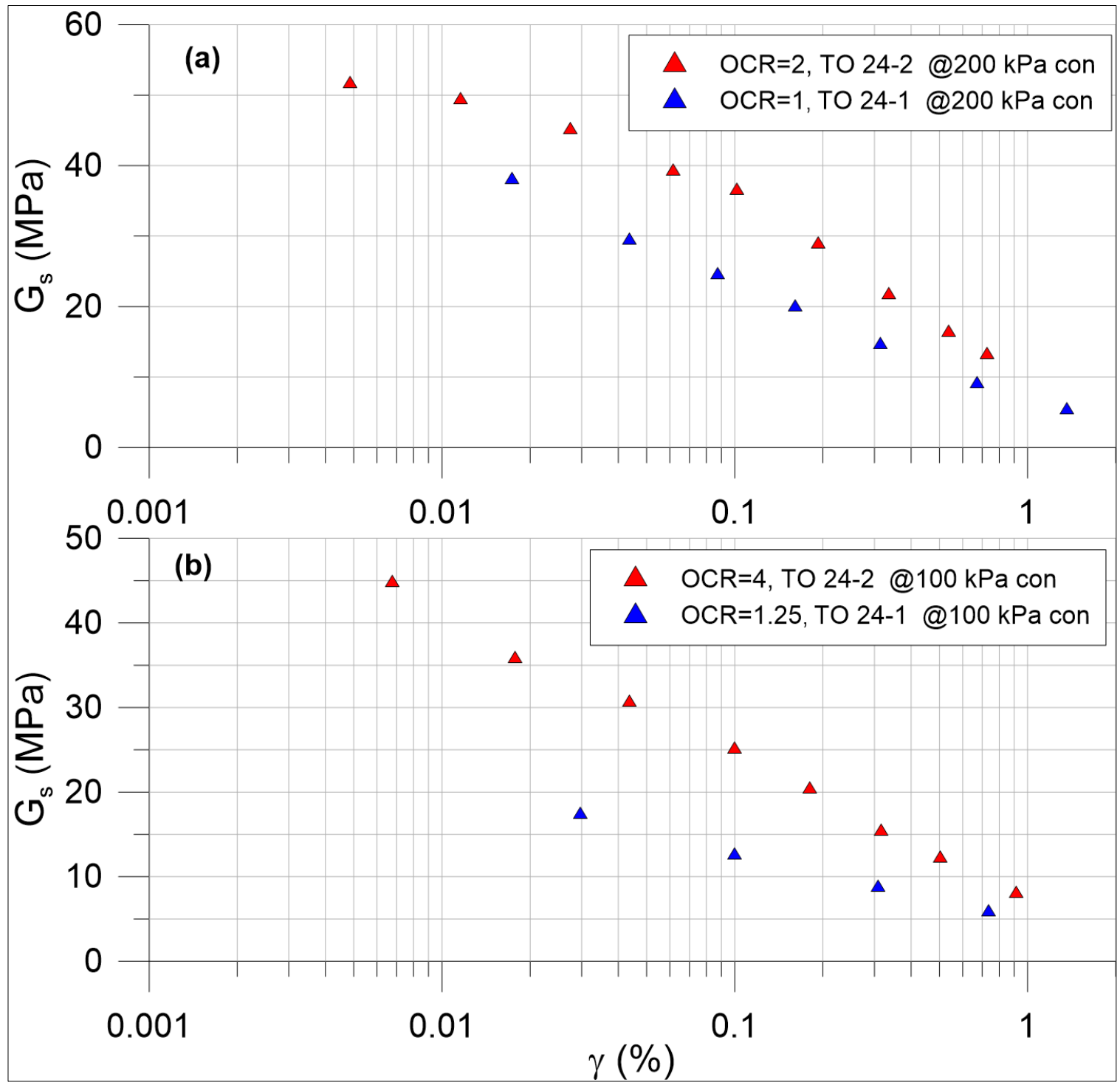

Figure 5-10 Shear modulus comparison at different OCR values 


\subsection{Modulus reduction and damping curves of sensitive Leda clay}

For the practical purposes, a single best fit line for modulus reduction and damping ratio curves are drawn for Breckenridge and Outardes-2 sites separately. The established site-specific curves are presented in Figures 5.11 and 5.12 for Breckenridge and Outardes-2 sites. In current practice, dynamic input parameters (modulus reduction and damping) for ground response analysis of clayey soil are often chosen from the sets of modulus reduction and damping curves proposed by Vucetic and Dobry (1991) with different plasticity index (PI). Therefore, those sets of curves are presented in the background along with the established site-specific curves for the comparison.

The best fit line for modulus reduction and damping ratio of Breckenridge sample obtained at a depth of $12.7 \mathrm{~m}$ with a plastic index value of $24.2 \%$ is shown in the Figure 5.11. Modulus reduction curve closely follows the proposed trend line by Vucetic and Dobry for the given PI value at the smaller range of shear strain $(\gamma<0.01 \%)$ and at the large shear strain range $(\gamma<1 \%)$. But $G_{s} / G_{\max }$ curve slightly deviates (Increased to higher PI curve) from the proposed PI curves during the medium range of strain. On the other hand, damping ratio of Breckenridge clay displays more scatted data especially at the very large strain range $(\gamma<1 \%)$. A dependency on damping OCR can be noted. The best fit line for the damping ratio of Breckenridge clay does not follow according to the sets of curves proposed by Vucetic and Dobry, but it closely follows the PI $=40$ curve in the small and medium shear strain ranges $(0<\gamma<1 \%)$ and thereafter it shifts towards higher PI curves $(\gamma>1 \%)$. 


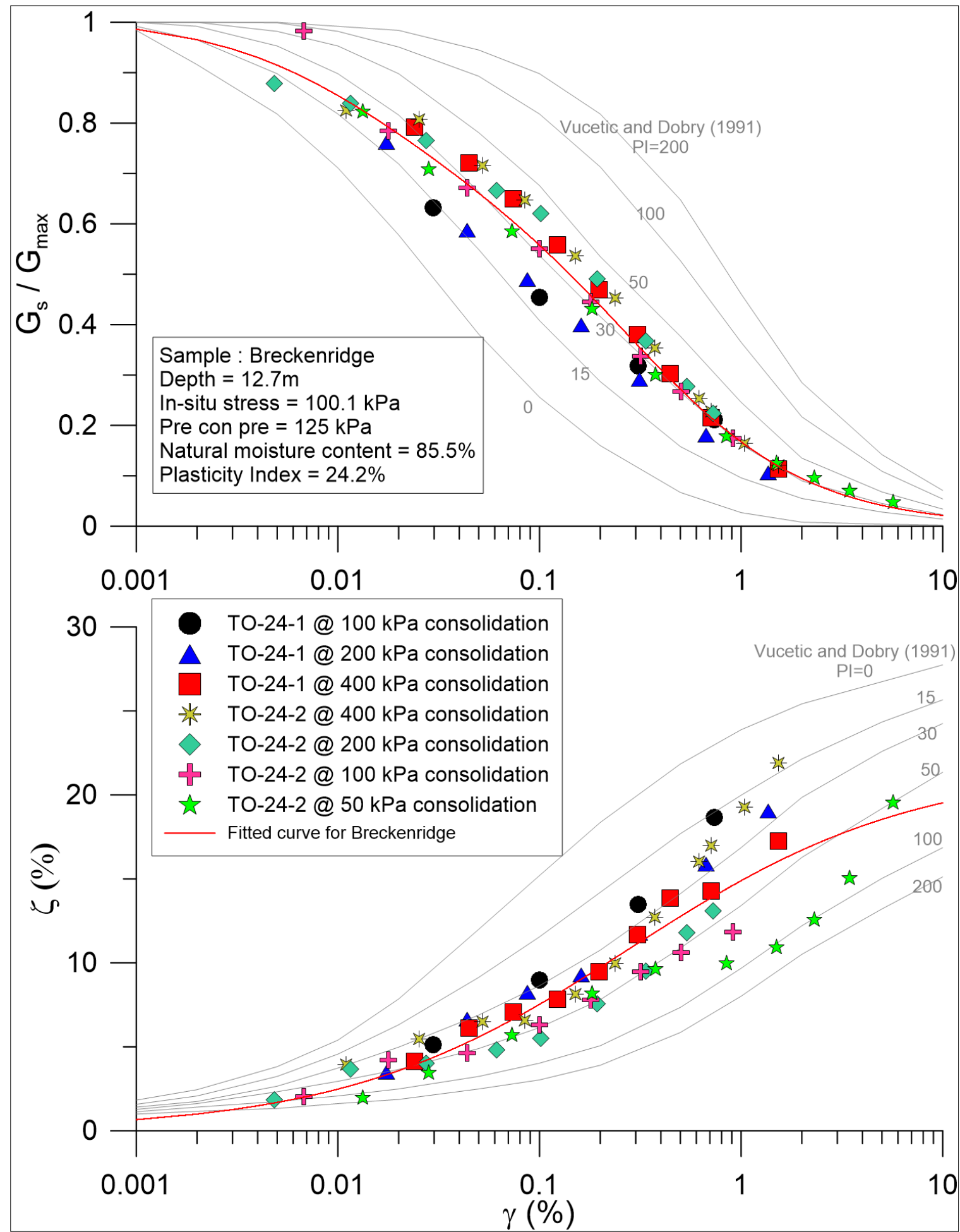

Figure 5-11 Best fit line of modulus reduction and damping of Breckenridge clay 


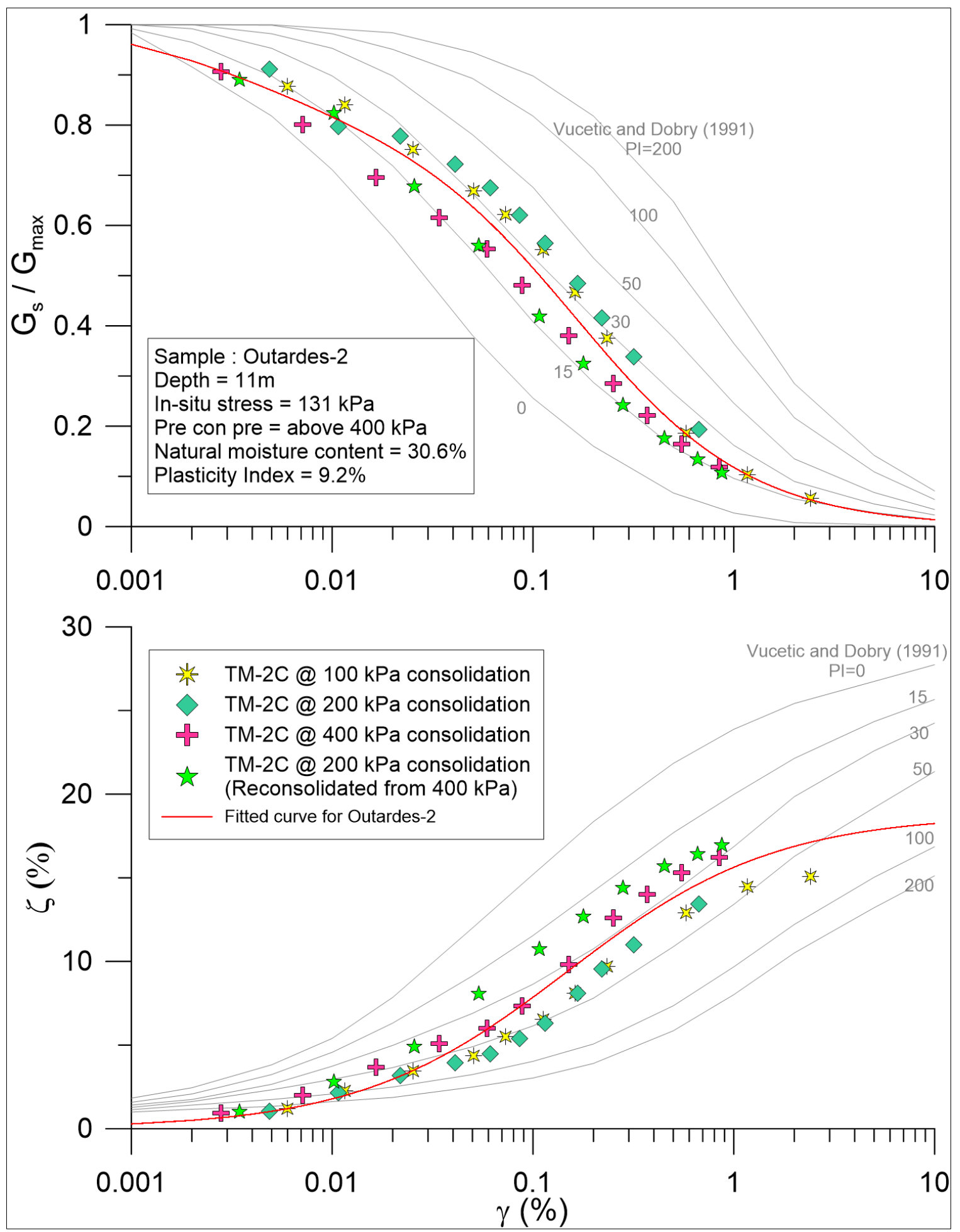

Figure 5-12 Best fit line of modulus reduction and damping of Outardes-2 clay 
The best fit curves for modulus reduction and damping for Outardes-2 clay with plasticity index of 9 are presented in Figure 5.12. The best fit modulus curve does not follow a particular value of PI curve proposed by Vucetic and Dobry. Similarly, the best fit damping ratio curve also does not follow a particular PI value curve proposed by Vucetic and Dobry. The influence of stress level on modulus reduction and damping ratio values of Outardes-2 clay is noticeable in the plot. Modulus reduction and damping ratio of the samples tested at higher OCR values (100 kPa and $200 \mathrm{kPa}$ consolidation) tend to follow higher PI value curves.

The above best fit curves patterns from this research study clearly state that sensitive Leda clay does not follow any specific proposed curves based on plastic index (PI) values by Vucetic and Dobry (1991). The similar conclusion has made by Theenathayarl (2015) and Thiruganasampanther (2016) based on cyclic simple shear test results on sensitive Leda clay. The results confirm that modulus reduction and damping ratio of sensitive clays are not directly relatable to their plastic index and cannot be represented by the proposed Vucetic and Dobry curves. Indeed, Vucetic and Dobry (1991) pointed out that behavior of sensitive clays could be different from their proposed sets of curves and emphasized the importance of site-specific curve. Therefore, a sitespecific modulus reduction and damping ratio curves are essential for an accurate and reliable ground response analysis on sensitive Leda clays. Hence the proposed sitespecific dynamic properties curves for Breckenridge and Outardes-2 site could be useful for the ground response analysis of above sites rather than picking a curve from the literature. 


\subsection{Triaxial vs simple shear response}

As discussed in the previous chapters, soil behavior is significantly influenced by the loading mode. Triaxial and simple shear devices induce very different loading paths on the soil sample. Generally, the loading direction is parallel to the natural bedding plane during simple shear loading, and the soil behaves symmetrically without a directional preference in simple shear loading. However, the loading direction is perpendicular to the bedding plan in the triaxial loading condition. Further the soil behaves differently during the compression and extension phases of the loading. Therefore, the stress-strain loop of soil under cyclic triaxial loading is not symmetrical.

In this research study, the modulus reduction and damping ratio tests are conducted on hydrostatically consolidated samples, (Figure 5.4), which implies that the soil is loaded in both triaxial compression and triaxial extension modes during each cycle. The calculated modulus and damping value are thus influenced by both triaxial compression and extension behavior of soil. Therefore, different values of modulus and damping ratio for same soil with similar initial stresses under simple shear and triaxial loading conditions are expected.

Thirugnanasampanther (2016) undertook an evaluation of the response of the same material under simple shear loading conditions. The reported values are compared with the cyclic triaxial rest results obtained from this research study in Figures 5.13 and 5.14 . 


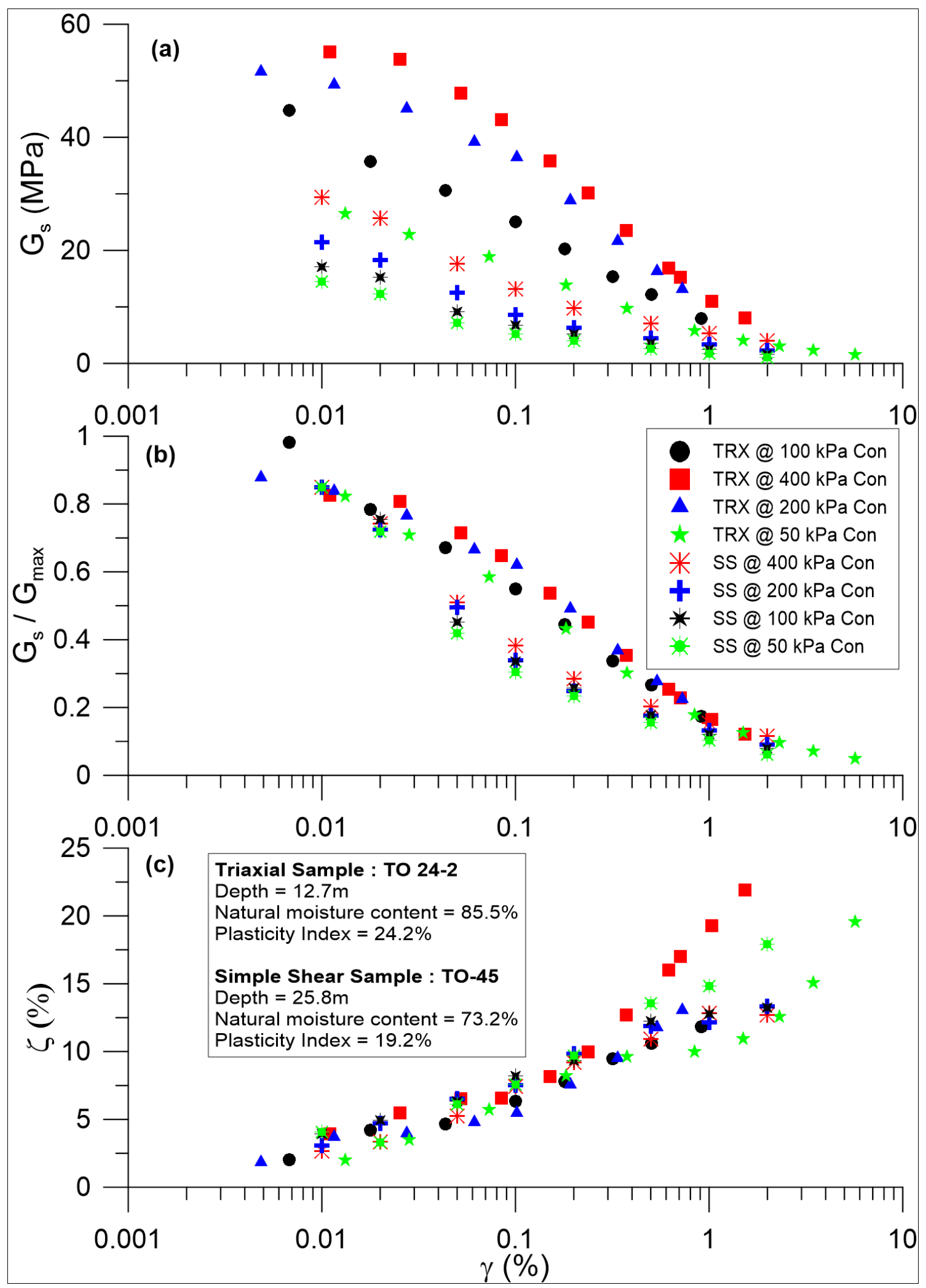

Figure 5-13 Comparison of Modulus and Damping ratio results of Breckenridge samples under Triaxial and Simple shear loading conditions 


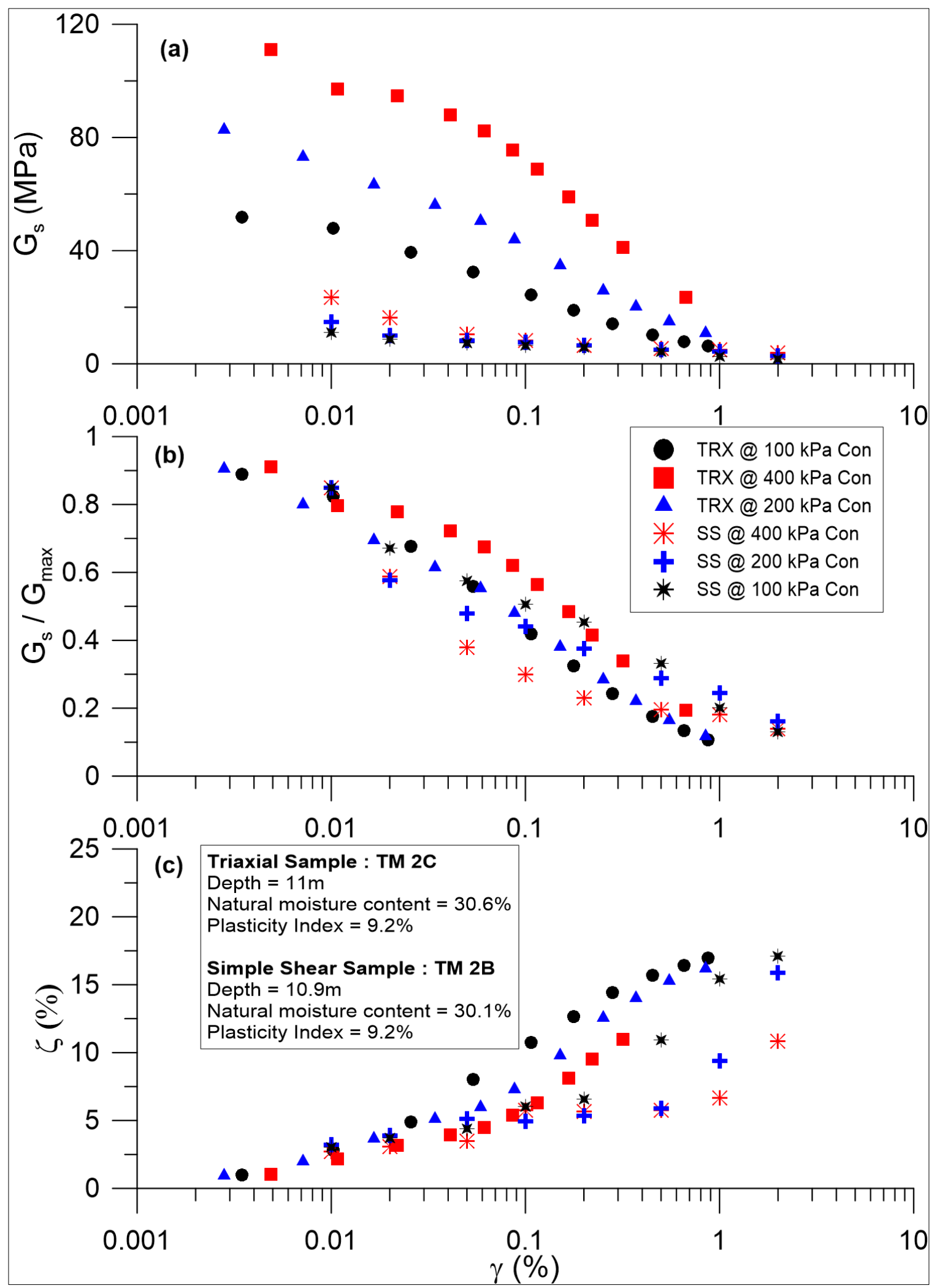

Figure 5-14 Comparison of Modulus and Damping ratio results of Outardes-2 samples under Triaxial and Simple shear loading conditions 
Figure 5.13 (a-c) compares the dynamics properties of Breckenridge clay in terms of secant shear modulus (a), normalized shear modulus (b) and damping ratio (c) under simple shear and triaxial loading. Triaxial specimens indicate a very high secant shear modulus than simples shear specimens as expected (Figure 5.13a). At $400 \mathrm{kPa}$ consolidation pressure triaxial specimen has a shear modulus of $55 \mathrm{MPa}$ and simple shear specimen has $29 \mathrm{MPa}$ at the same strain level; which is nearly half of the value of triaxial shear modulus. It should be noted that Breckenridge samples resulted a similar comparison in their monotonic tests. Simple shear and triaxial specimens showed a normalized monotonic peak shear strength $\left(S_{u} / \sigma_{c}^{\prime}\right)$ ratio of of 0.34 and 0.63 respectively. In terms of normalized shear modulus both triaxial and simple shear devices result a similar pattern at very small and very large strain levels, but triaxial results are quite higher at the medium range of strain level $(0.01<\gamma<1)$. The damping ratio of triaxial results are more scattered at the large range of strain but simple shear and triaxial damping trends are quite similar at small and medium range of strain in Breckenridge clay as shown in Figure $5.13 \mathrm{c}$.

Figure 5.14 (a-c) compares the dynamic properties of Outardes-2 clay under triaxial and simple shear loading conditions. Triaxial specimens again have a high secant shear modulus than simple shear specimens. At $400 \mathrm{kPa}$ consolidation pressure, triaxial specimen shows $96 \mathrm{MPa}$ of shear modulus at $0.01 \%$ shear strain, but simple shear specimen shows only $23.5 \mathrm{MPa}$ of shear modulus at the same strain level. Outardes-2 clay also follows a similar trend as observed in Breckenridge clay in terms of normalized shear modulus. Triaxial and simple shear normalized shear modulus assume similar trends at small and large shear strain levels, but triaxial results show higher normalized 
shear modulus at the medium range of strain $(0.01<\gamma<1)$. Triaxial specimens result to a higher value of damping ratios compared to simple shear values and the difference between those damping value increases with increasing shear strain level. Similar observations could also be noted in the Breckenridge test results.

\section{$5.7 \quad$ Tests on sand}

Some monotonic compression and extension test were carried out on FRS initially and the obtained results were compared with those presented results in the literature to confirm the reliability of testing device and testing procedure. Effective stress state at phase transformation during all monotonic compression and extension tests are shown in Figure 5.15. It can be seen in the figure that the locus of the stress states at phase transformation is a straight line passing through the origin regardless of the initial stress state, density, consolidation history and loading mode. Further, the mobilized friction angle $\left(\varphi_{P T}\right)$ is about $32^{\circ}$ in both compression and extension loading modes. The unique friction angle at phase transformation for FRS has been reported by several researchers (Vaid and Chern, 1985; Vaid and Tomas,1994; Logeswaran, 2005). The obtained $\varphi_{P T}$ coincides with the literature and confirms the reliability of testing apparatus and testing method. 


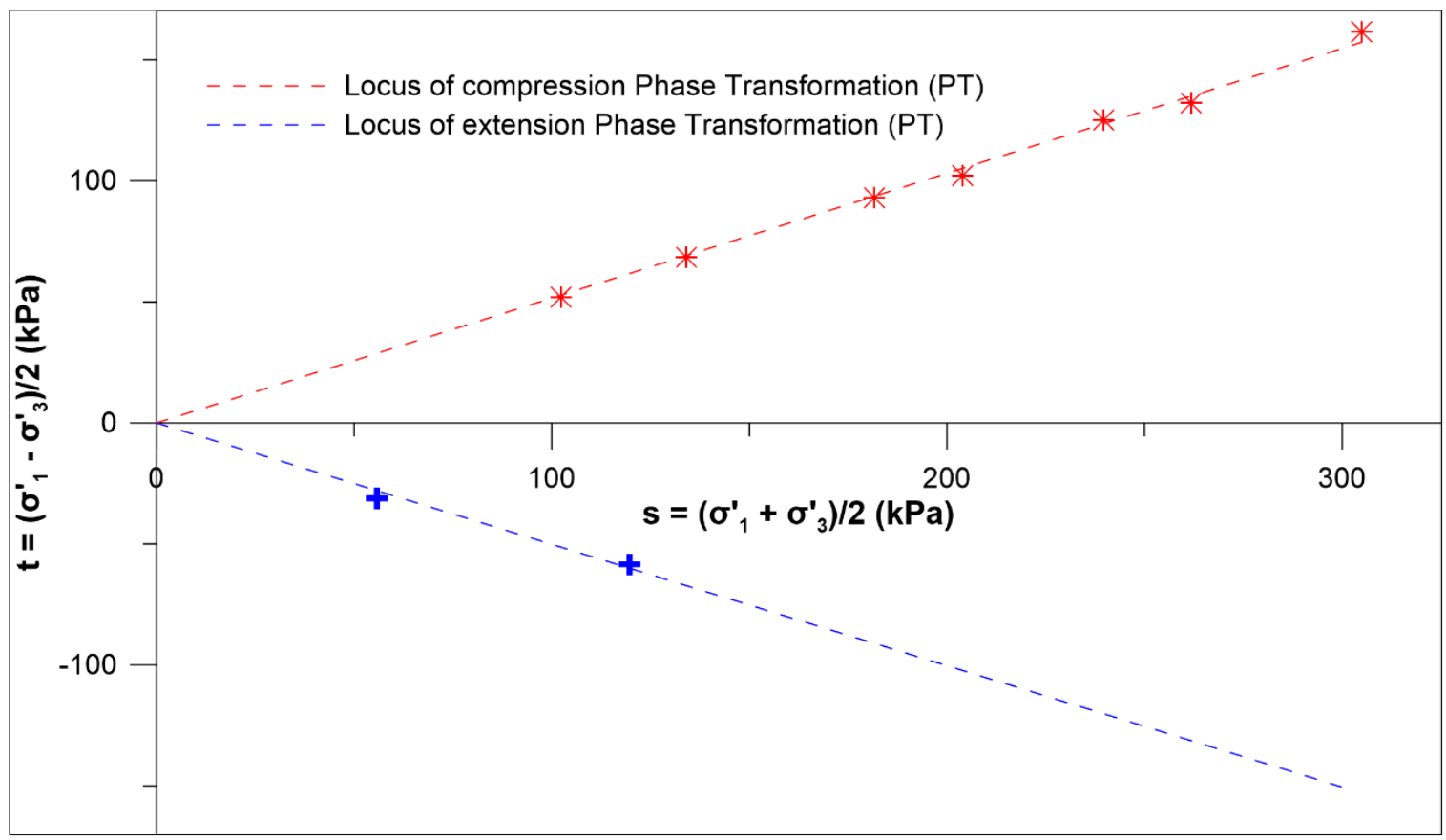

Figure 5-15 Locus of phase transformation of Fraser River sand

\subsubsection{Shear modulus and damping ratio characteristic of sand}

A series of stress-controlled quasi-cyclic tests were conducted on Fraser River sand and Ottawa sand. Tests were conducted on specimens at different relative densities (loose and dense), different consolidation pressures (100 kPa, $200 \mathrm{kPa}$ and $400 \mathrm{kPa})$ and different consolidation stress ratio $K_{c}(0.5,0.67,1.0 \& 1.5)$. The coefficient of consolidation pressure $(\mathrm{Kc})$ is defined as the ratio between vertical and horizontal consolidation pressures. $K_{c}=\sigma_{1 c}^{\prime} / \sigma_{3 c}^{\prime}$

During the anisotropic consolidation conditions $\left(K_{c} \neq 1\right)$, and the consolidation pressure is considered to be the mean effective consolidation pressure given by

$$
\sigma_{m}^{\prime}=\frac{\left(2 \sigma_{h}^{\prime}+\sigma_{v}^{\prime}\right)}{3}
$$

The horizontal and vertical consolidation pressures were chosen according to the above equation at each mean effective consolidation pressure level and $K_{c}$. For example 
to test a specimen at $200 \mathrm{kPa}$ mean effective consolidation pressure and at $K_{c}$ of 1.5 , $257.14 \mathrm{kPa}$ of $\sigma_{v}^{\prime}$ and $171.43 \mathrm{kPa}$ of $\sigma_{h}^{\prime}$ were chosen. In the beginning, some of the tests were conducted without considering the mean effective consolidation stress $\left(\sigma_{v c}^{\prime}=240\right.$ $\mathrm{kPa}$ and $\sigma_{h c}^{\prime}=160 \mathrm{kPa}$ for $K_{c}=1.5$ which gives a mean effective consolidation stress of $186.67 \mathrm{kPa}$ ) and the results at both conditions are discussed later in this chapter.

\subsubsection{Calculation of secant shear modulus and damping ratio of sand}

Three stress-controlled quasi-cyclic loading cycles were applied on the consolidated sand specimen with a decided level of deviatoric stress in order to obtain a targeted axial strain. Out of these three stress-strain cycles, the second cycle was chosen as the suitable cycle to calculate secant shear modulus and damping ratio at that strain level as similarly applied in clay tests. Unlike in the clay tests, after the three loading cycles at a particular deviatoric stress level the drainage was allowed in the specimen in order to reconsolidated the sand to the initial stress state before the next quasi-cyclic loading. This procedure permits testing the specimen at the same effective stress conditions at each loading conditions, but with minor changes in relative density. As noted previously, the maximum change in relative density change was only about $1 \%$.

Figure 5.16 shows the typical stress controlled quasi-cyclic loading results of isotopically consolidated FRS specimen at $\sigma_{c}^{\prime}=100 \mathrm{kPa}$ and $D_{r c}=33 \%$. The pore water pressure generation and axial strain development with increasing deviatoric cyclic stress is indicated in the Figure 5.16. Furthermore, it can be observed in Figure 5.16 (b) that the pore water pressure increases at each three set of cyclic loadings (non-drained) and it is totally dissipated at the end of each third cycle (stage-drained) and again start to generate from a zero value. Also, the pore water pressure generation between the three 
non-drained quasi-cyclic loading cycles is very small at small strain levels but, rapidly increased at the elevated range of strain (nearer to failure). This would render the staged testing unsuitable at such strain levels, and therefore, in the majority of these tests, the shear modulus and damping data is presented to a limited range of shear strains $(0.5 \%$ or less).

The typical sets of stress-strain loops for the above-mentioned sample are presented in Figure 5.17. The secant shear modulus and the damping ratio at the respective strain level were calculated from those each loop by the similar way followed in clay. Similar loops were obtained for each test to calculate secant shear modulus and damping ratio of FRS and Ottawa sand. The maximum shear modulus values are also calculated using similar methods employed in clay soils, and the secant shear modulus at $0.01 \%$ of shear strain is assumed to be equal to $85 \%$ maximum shear modulus value. 


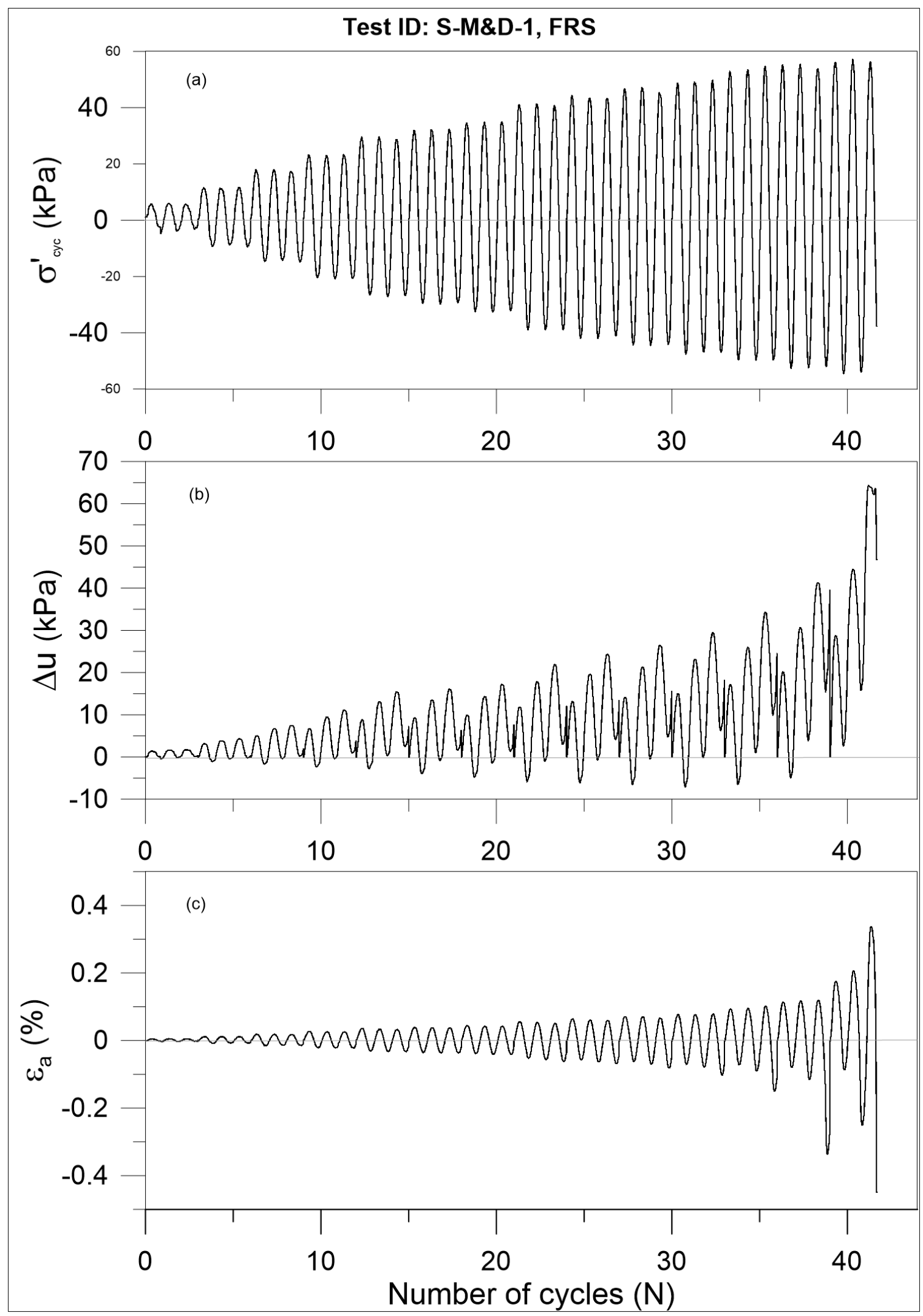

Figure 5-16 Typical behavior of FRS during stage-drained stress-controlled quasi-cyclic loading 


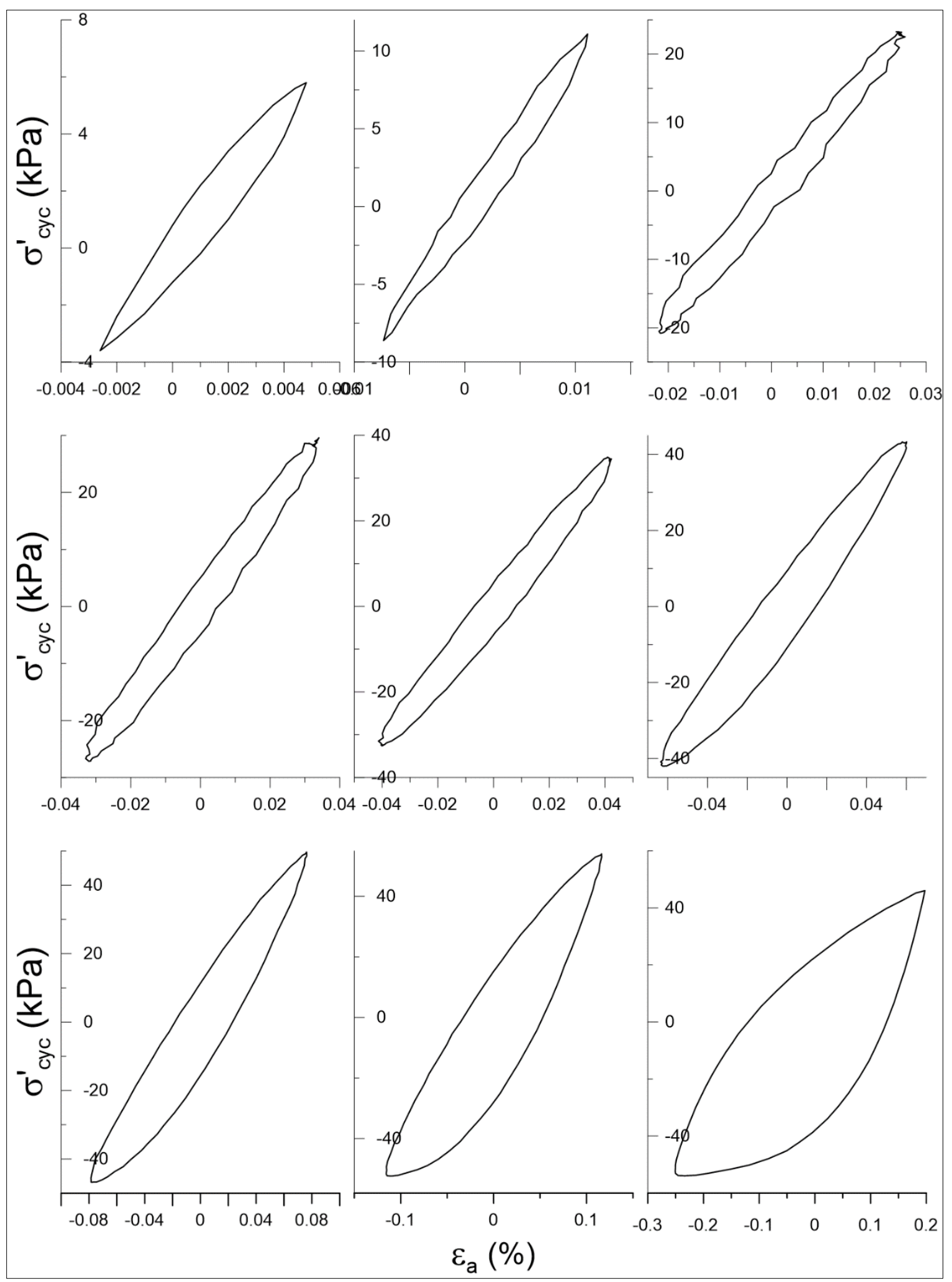

Figure 5-17 Typical stress-strain loops of FRS 


\subsubsection{Secant shear modulus, normalized shear modulus and damping ratio characteristics}

Figures 5.18(a-c) to 5.24(a-c) present the characteristic of secant shear modulus $\left(\mathrm{G}_{\mathrm{s}}\right)$, normalized shear modulus $\left(\mathrm{G}_{\mathrm{s}} / \mathrm{G}_{\max }\right)$ and damping ratio $(\xi)$ of Fraser River sand and Ottawa sand at different loading conditions and densities. Figure 5.18(a-c) represents the dynamic results of isotropically consolidated loose FRS $(\mathrm{Dr}=33 \pm 3 \%)$ at $\sigma_{3 c}^{\prime}=100 \mathrm{kPa}$, $200 \mathrm{kPa}$ and $400 \mathrm{kPa}$. Figure 5.19(a-c) compares the results of isotopically consolidated dense FRS $(\mathrm{Dr}=63 \pm 2 \%)$ at different consolidation pressures. The data follow typical trend lines in the literature, and significant dependency of secant shear modulus and damping ratio on consolidation pressure can be identified in each figure. However, the effect of consolidation pressure is not significant in the normalized shear modulus behavior. Furthermore, dense sand specimens show a higher secant shear modulus, and these observations also agree with literature.

Dynamic properties of Ottawa sand at loose and dense stages are presented in Figures 5.20(a-c) and 5.21(a-c). In comparison to FRS, Ottawa sand shows a slightly higher secant shear modulus values.

Figures 5.22(a-c) to 5.24(a-c) represent the dynamic properties of anisotropically consolidated $\left(\mathrm{K}_{\mathrm{c}} \neq 1\right)$ FRS specimens. The first graph (5.22) compares the tests conducted at different mean effective consolidation pressures and at different $\mathrm{K}_{\mathrm{c}}$ values. Figure 5.23 represent the tests conducted at $200 \mathrm{kPa}$ mean effective consolidation pressure at different $\mathrm{K}_{\mathrm{c}}$ values on loose FRS, final plot represents the tests conducted at $100 \mathrm{kPa}$ mean effective consolidation pressure. 


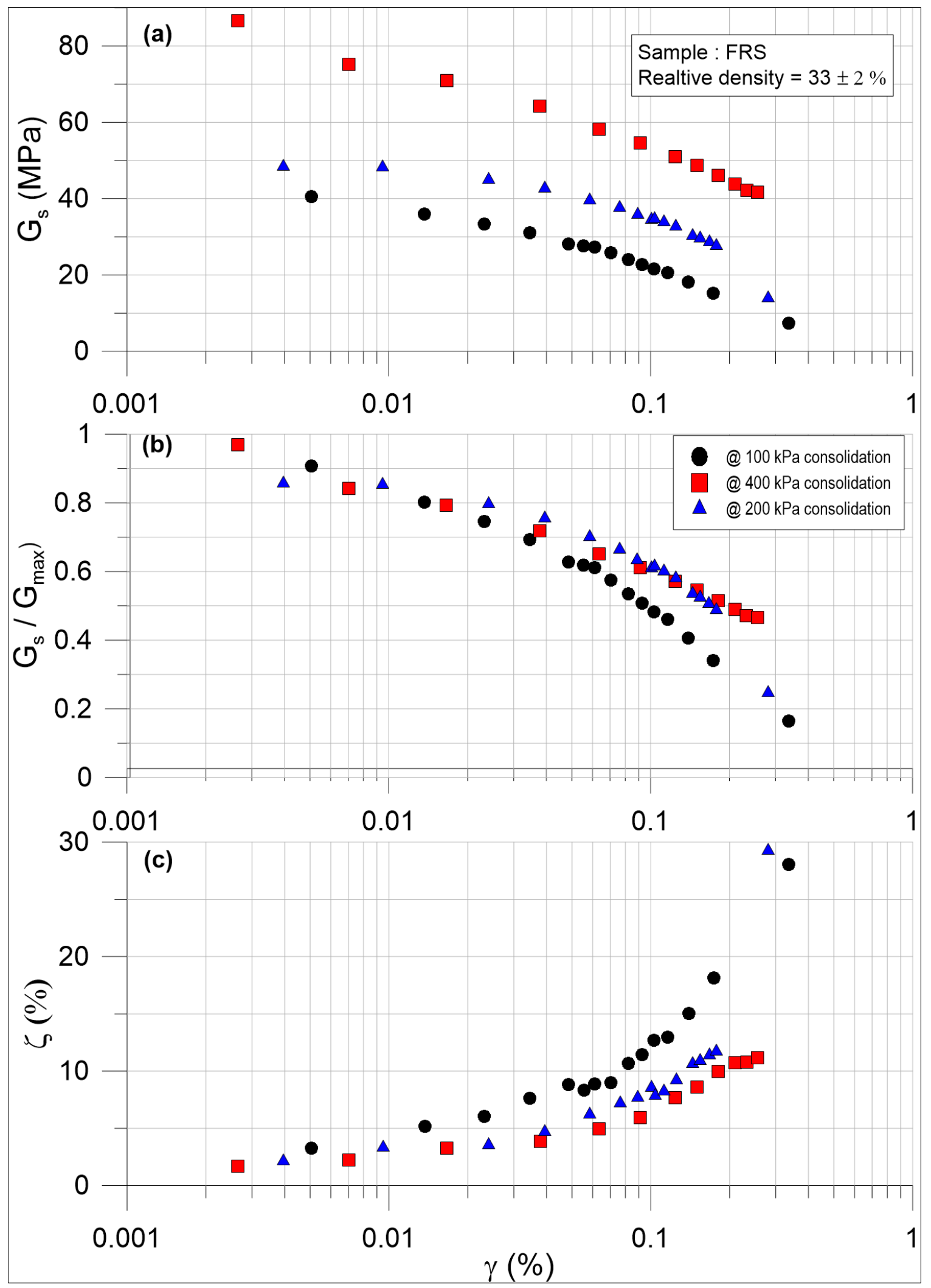

Figure 5-18 Dynamic properties of loose FRS at isotopically consolidation 


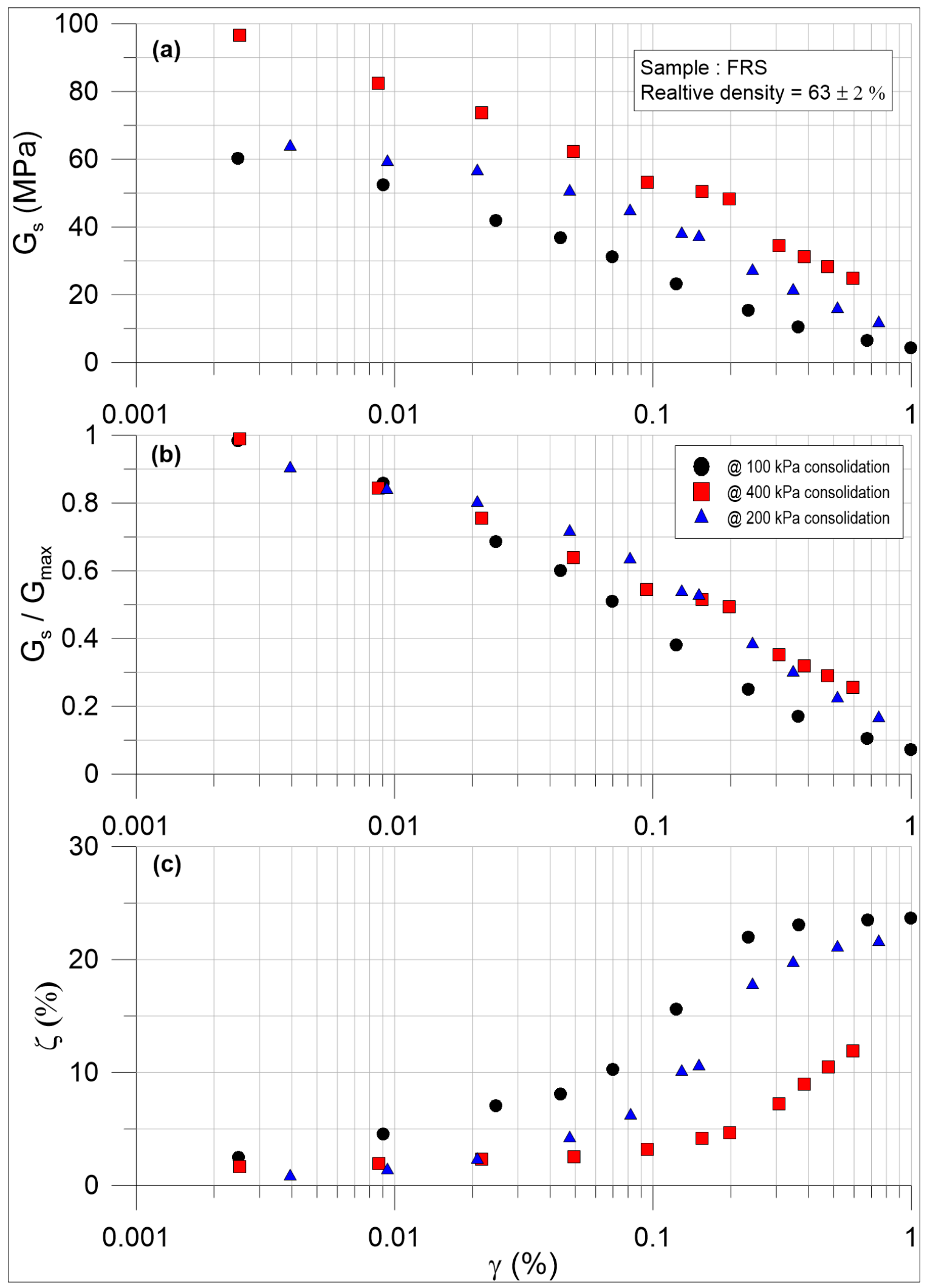

Figure 5-19 Dynamic properties of Dense FRS at isotopically consolidation 


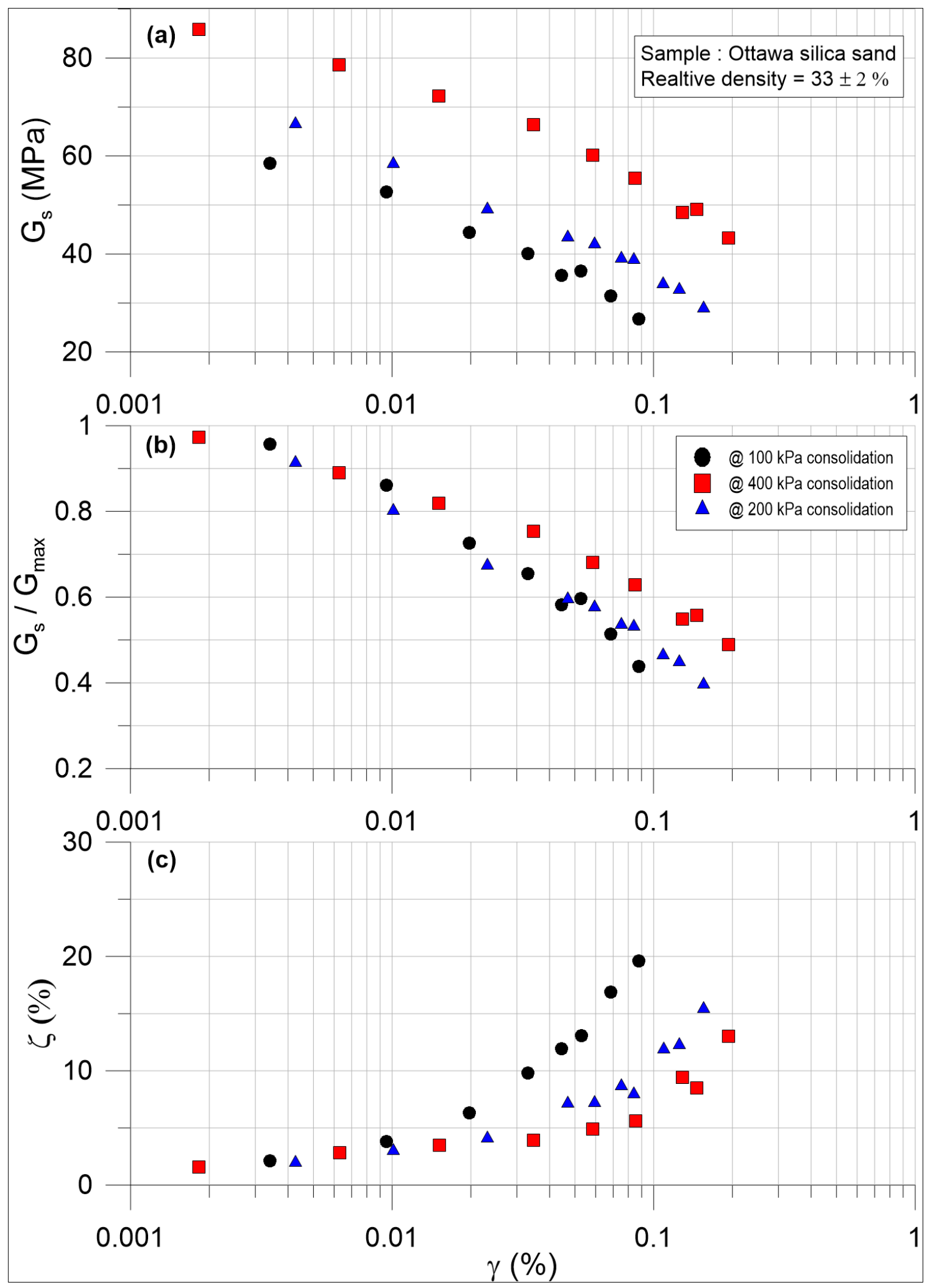

Figure 5-20 Dynamic properties of loose Ottawa sand at isotopically consolidation 


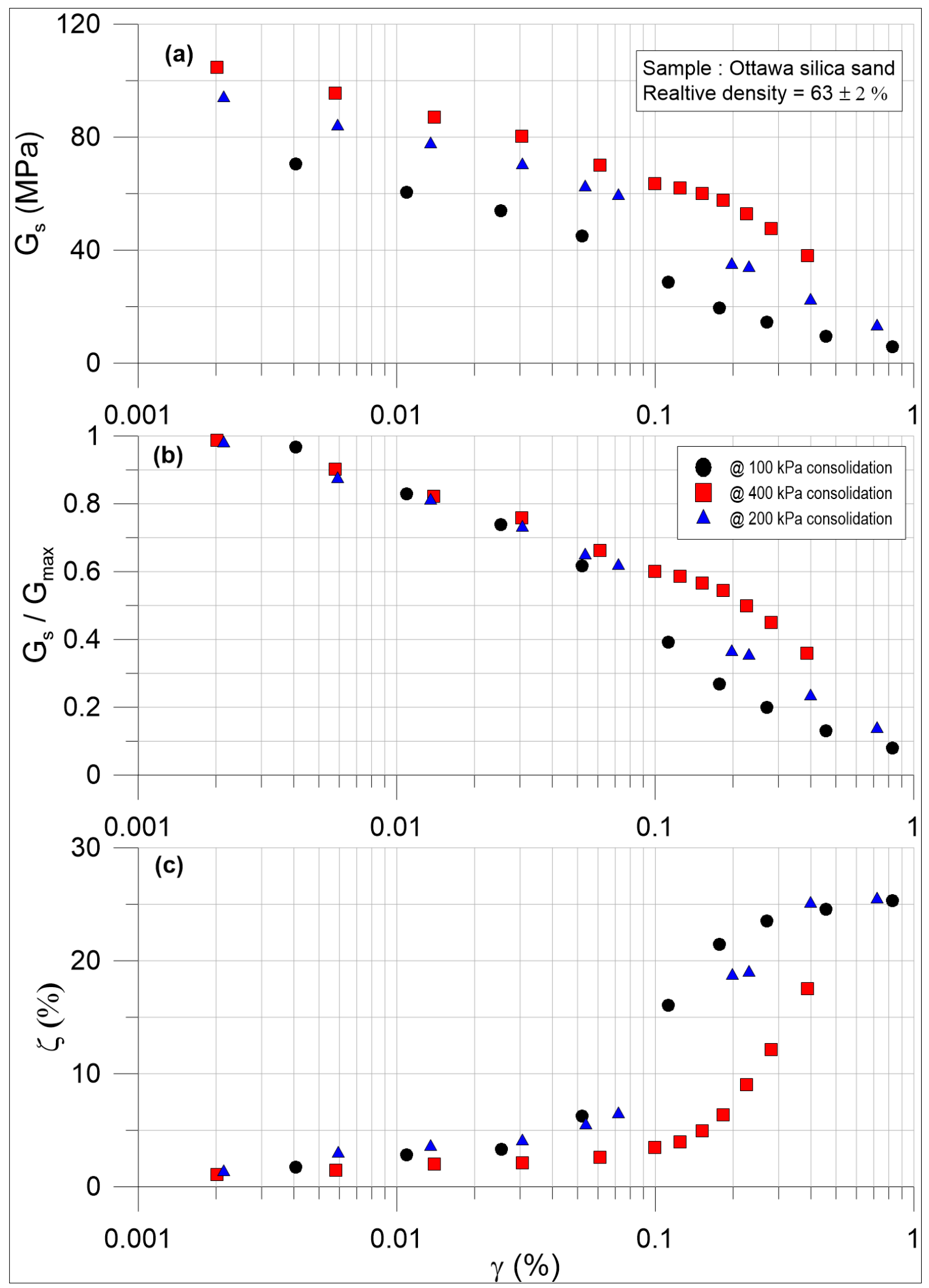

Figure 5-21 Dynamic properties of dense Ottawa sand at isotopically consolidation 


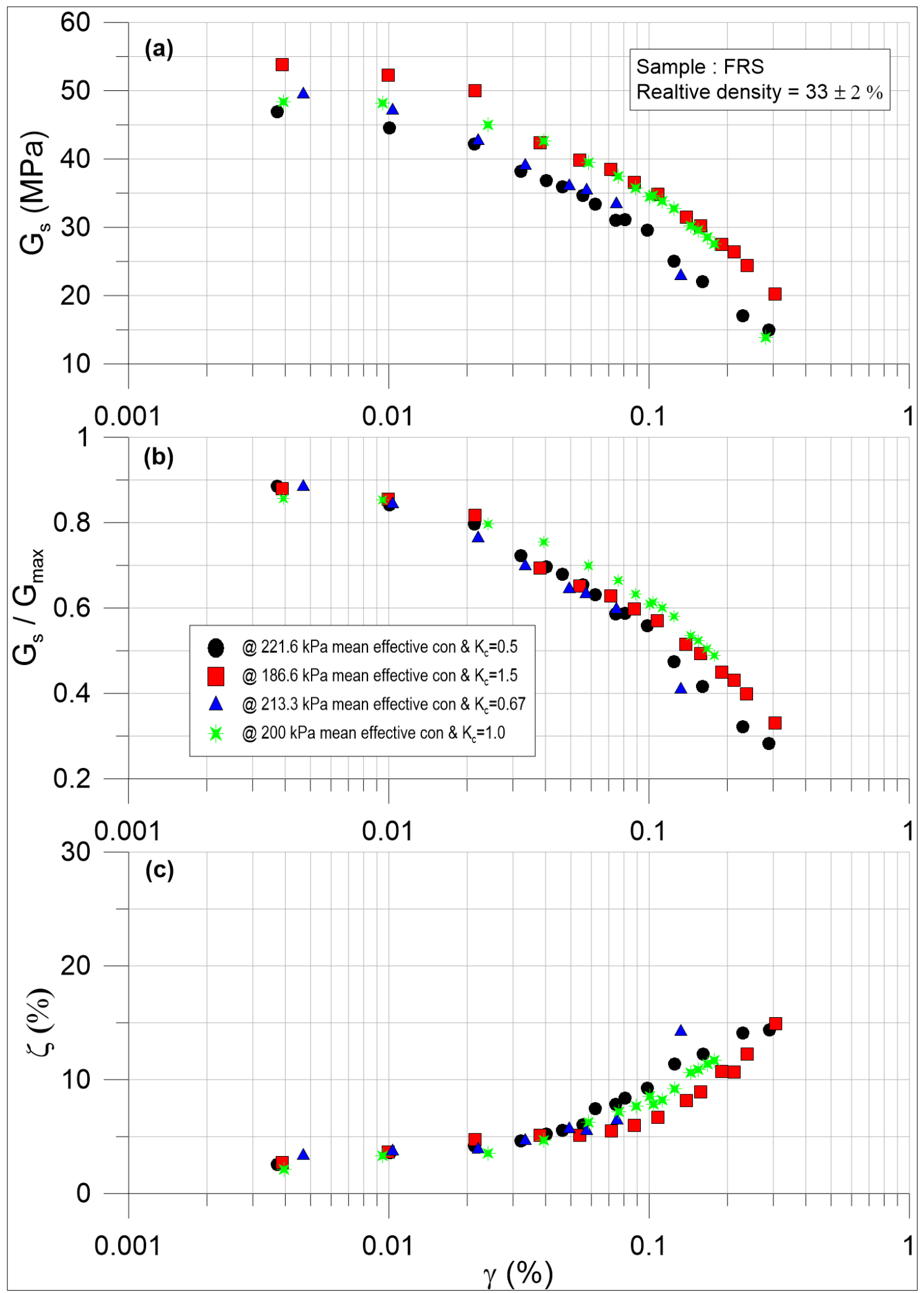

Figure 5-22 Dynamic properties of loose FRS at anisotropically consolidation (different mean effective consolidation pressure 


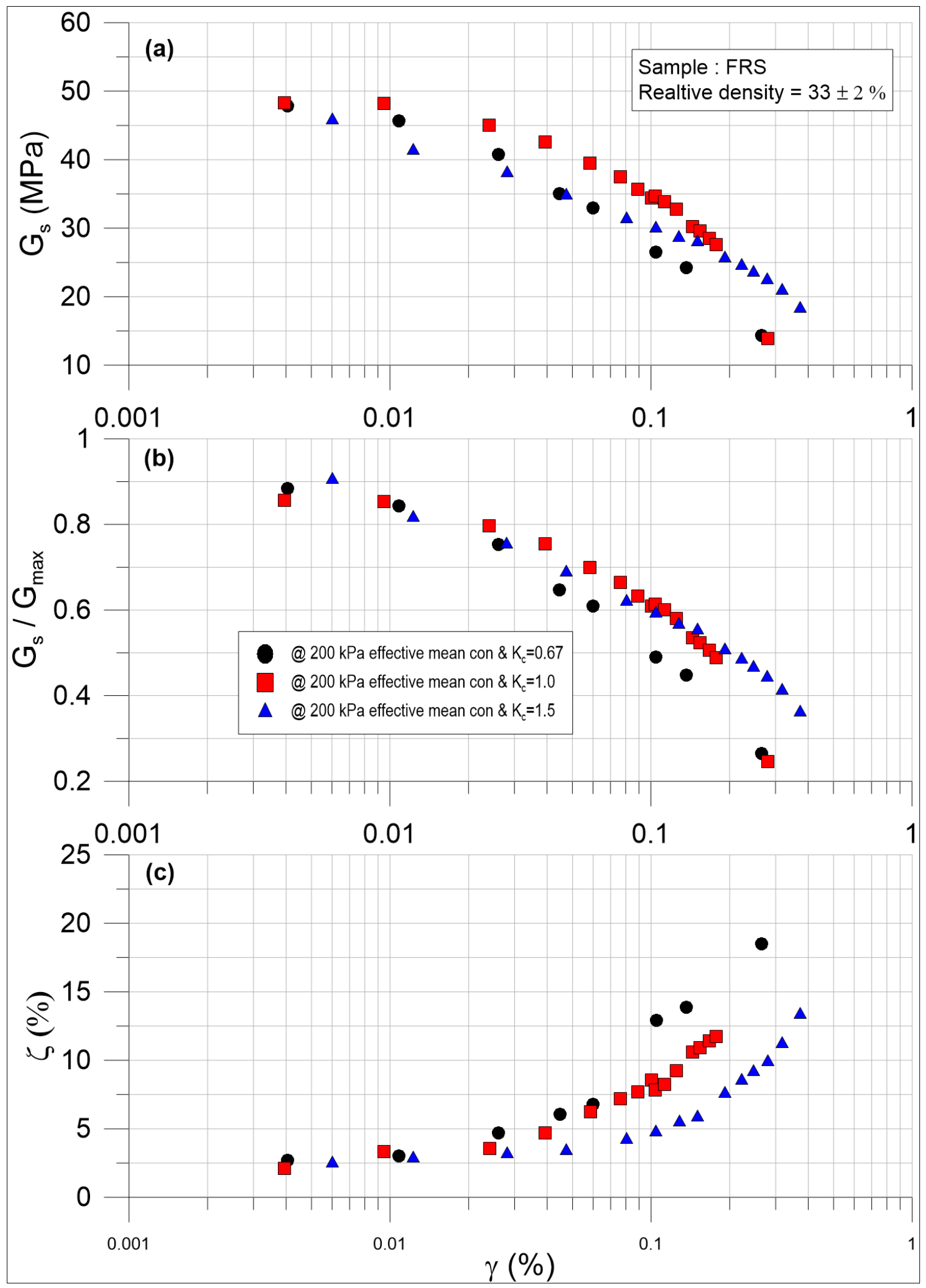

Figure 5-23 Dynamic properties of loose FRS at $200 \mathrm{kPa}$ mean effective anisotropically consolidation 


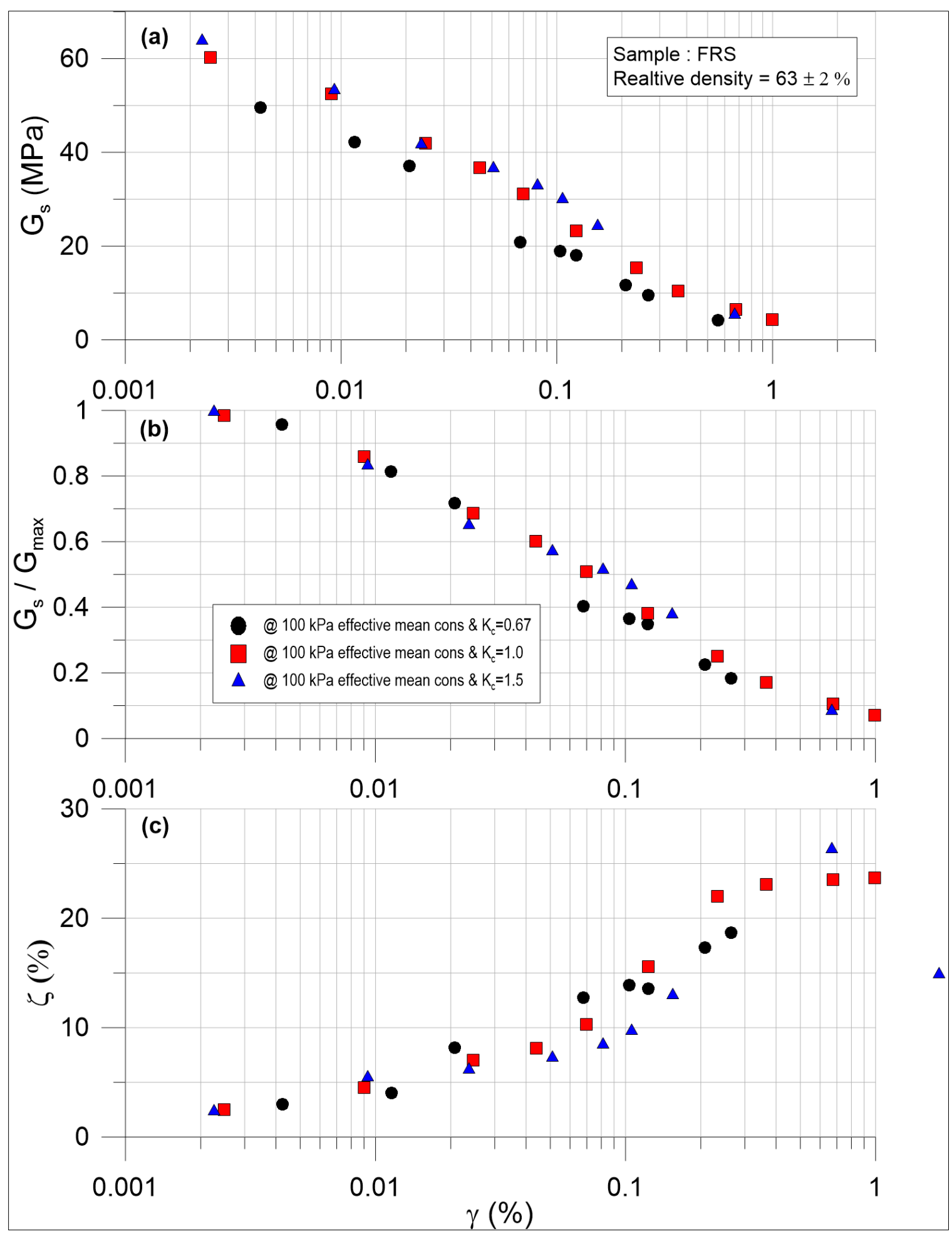

Figure 5-24 Dynamic properties of dense FRS at $100 \mathrm{kPa}$ mean effective anisotropically consolidation 
The effects of mean effective consolidation pressure and consolidation stress ratio $\left(\mathrm{K}_{\mathrm{c}}\right)$ are combined in the results shown in Figure 5.22, but Figures 5.23 and 5.24 hilights the the effect of consolidation stress ratio at constant mean effective consolidation pressures. It can be observed that there is some effect of $\mathrm{K}_{\mathrm{c}}$ on secant shear modulus, yet the data points are scattered in Figures 5.23 and 5.24, therefore more research is required to draw a clear conclusion regarding the effect of $K_{c}$ in secant shear modulus and damping ratio.

\subsubsection{Modulus reduction and damping ratio curves of sands}

The best fits modulus reduction and damping ratio curves of water puluviated Fraser River sand and Ottawa sand under triaxial loading conditions are presented in Figures 5.25 and 5.26. Best fit lines are drawn with the tests conducted at different consolidation pressures and different densities in each site. The modulus reduction and damping ratio curve proposed by Seed and Idriss (1970) for sands with lower, average and upper boundaries are included in broken lines in the background of above figures for comparison purpose.

The modulus reduction values obtained from this research study display a decently consistent data for FRS and Ottawa sand specimens, however damping ratio points are more scattered. The best fit lines for modulus reduction of both FRS and Ottawa sand follow a very similar pattern (well above the upper bound curve), but those are not in the boundaries proposed by Seed and Idriss (1970). The best fit line of damping ratio for FRS follows the lower boundary curve of Seed and Idriss while Ottawa sand does not follow the lower boundary cure at higher strain level. 


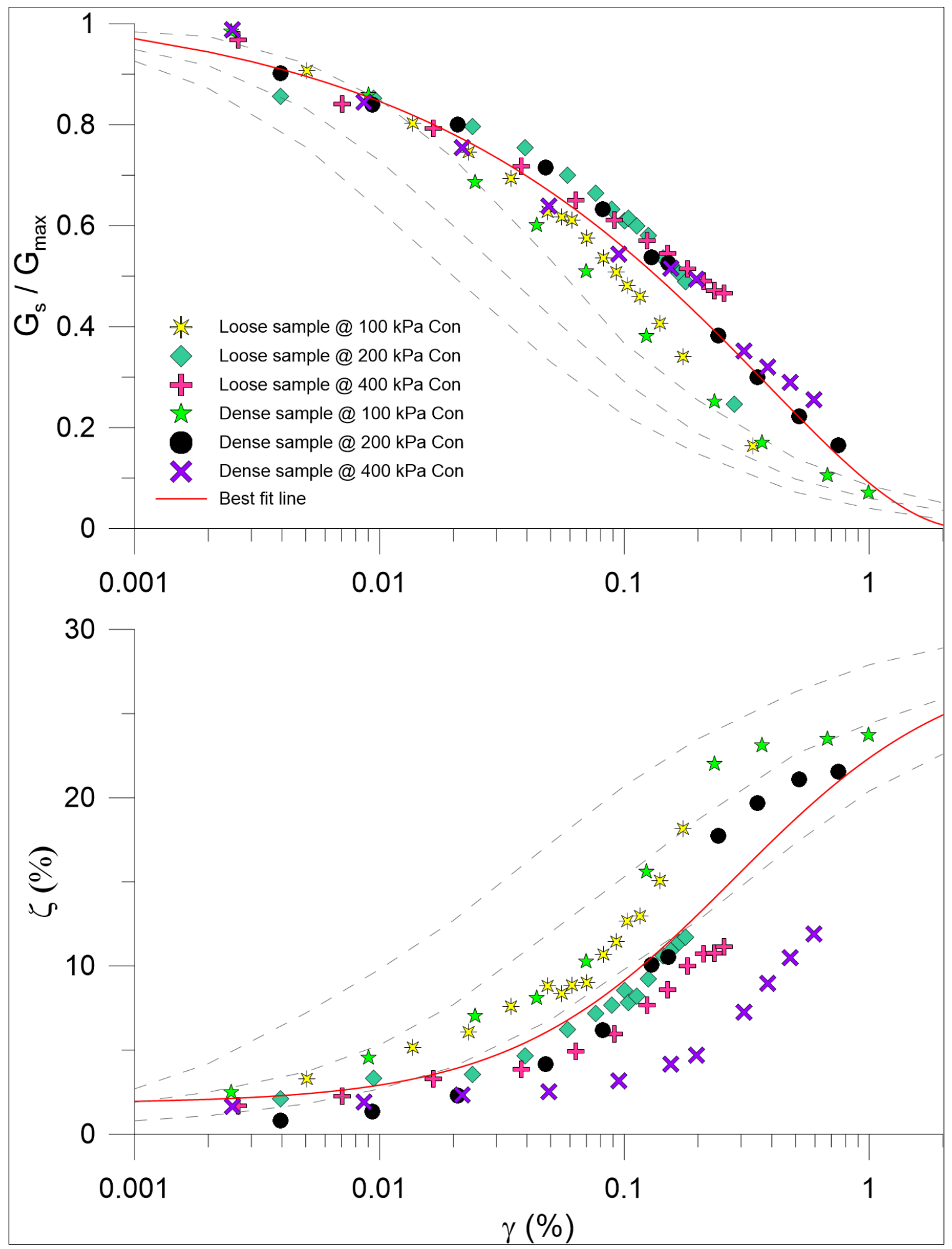

Figure 5-25 The best fit line of modulus reduction and damping ratio of FRS 


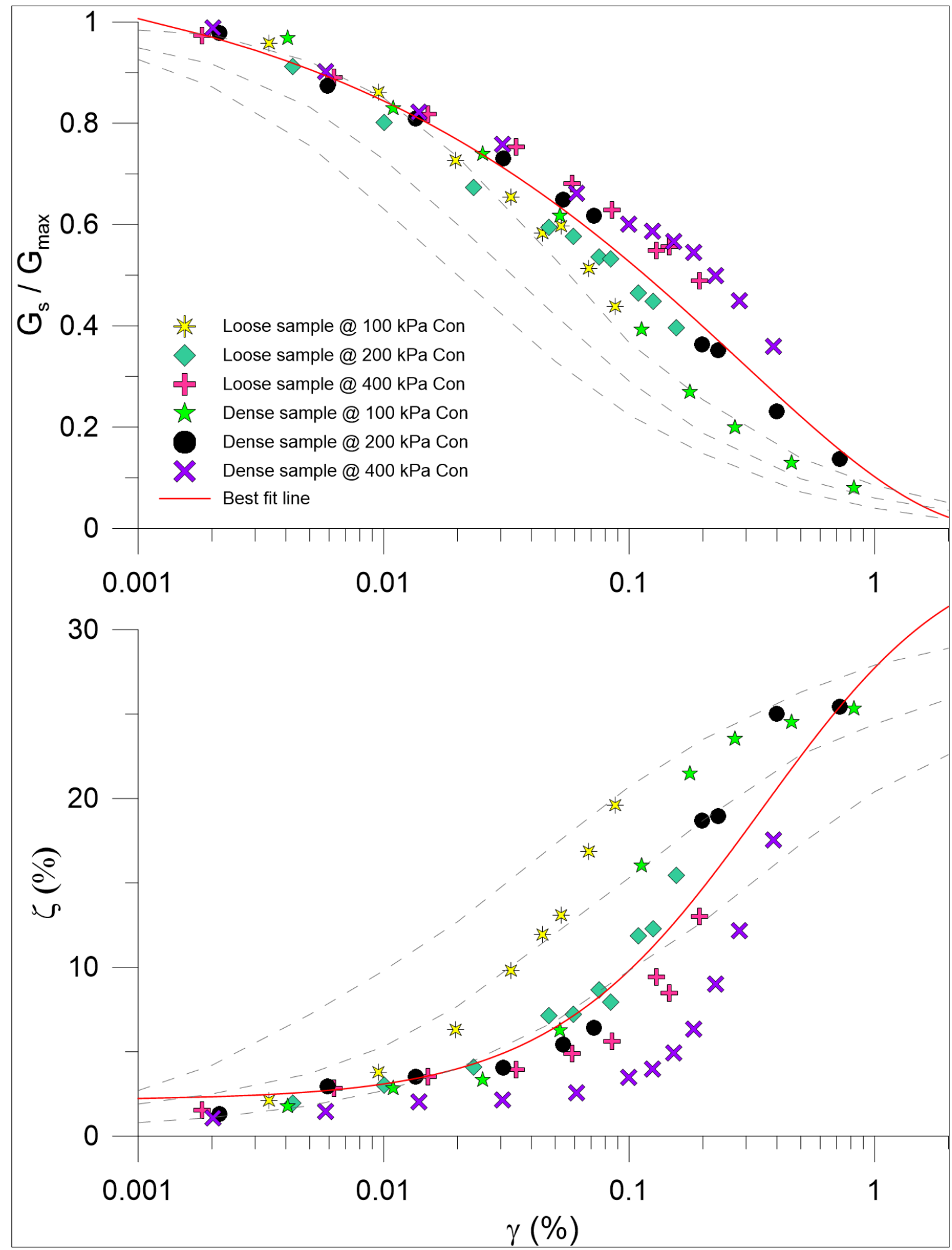

Figure 5-26 The best fit line of modulus reduction and damping ratio of Ottawa sand 


\section{Summary and conclusions}

\subsection{Summary}

The research project reported herein was undertaken with the aim of providing material or site specific dynamic properties of sensitive Leda clay, which underlies parts of Eastern Canada, and Fraser River sand that underlies heavily populated Lower Mainland region in British Columbia. The effects of loading mode on modulus reduction and damping curves were also assessed. This project entailed the carrying out of a detailed experimental study to establish site specific dynamic properties of sensitive Leda clays obtained from Quebec and near Eastern Ontario area (Breckenridge and Outardes). Undrained monotonic, cyclic and post-cyclic behaviors of Leda clay were also studied. Moreover, an attempt was made to detect the effects of consolidation stress ratio $\left(\mathrm{K}_{\mathrm{c}}\right)$ on dynamic characteristic of FRS. Undisturbed clay samples and water puliviated sand samples were tested under undrained triaxial loading conditions.

The performance of Carleton triaxial device was enhanced to successfully measure the very small level of strain and stress to establish reliable dynamic properties of soil at very small strain levels. The evaluated results from this study have been compared to the results reported from simple shear loading condition for the same material.

\subsection{Conclusions}

Some of the key conclusions from this experimental study can be listed as follows. Regarding undrained monotonic shear strength of sensitive Leda clay, it can be observed that the clear peak strength could be noticed when consolidated pressures were high. Additionally, it can be observed that the peak strength is realized at gradually 
increasing strain levels as consolidation stresses increase. Typically, the peak state was reached within about $1 \%-4 \%$ axial strain. The normalized peak shear strength of Leda clay $\left(S_{u} / \sigma_{c}^{\prime}\right)$ at in-situ stress state varied from 0.26 to 1.06 . Additionally, the variances could be minimized if the in-situ pre-consolidation pressure, $p_{c}^{\prime}$ is used as the normalizing parameter.

Additional findings indicated that;

$>\left(S_{u} / \sigma_{c}^{\prime}\right)$ of overly consolidated clay is significantly higher than normally consolidated clay

$>S_{u} / \sigma_{c}^{\prime}$ values of normally consolidated clays were typically around 0.5 but in OC clays $S_{u} / \sigma_{c}^{\prime}$ values vary significantly with OCR and clay types.

Normalized stress - strain curves, excess pore water pressure curves and stress paths of NC samples fall in a narrow range but overly consolidated samples showed a noticeably deviation.

$>$ Breckenridge samples indicated an average effective friction angle of $20.3^{\circ}$ with $25.7 \mathrm{kPa}$ of cohesion at peak state and Breckenridge and Outares-2 at residual yield an effective friction angle of $34.5^{\circ}$ with $4.17 \mathrm{kPa}$ of cohesion.

C Concerns have been expressed about the quality of some Breckenridge samples. There has been a significant fissure in the Breckenridge sample. This issue would also affect the reliability of the measured data to some extent, and might explain the variances noted in the $\varphi^{\prime}$ values.

The peak strength mobilized in this triaxial tests at in-situ stress levels was somewhat larger compared to simple shear. 


\subsubsection{Undrained cyclic and post-cyclic behaviour of Leda clay}

$>$ The strain development in the sample during cyclic loading is not symmetric in compression and extension sides on account of anisotropy. Soil responses is stronger in compression weaker is extension loading modes.

All the cyclic tests in this study failed in the extension mode. Also, it should be noted that, all the Breckenridge samples failed suddenly, in a manner similar to the true liquefaction is loose sands. Axial strain development in Outardes-2 samples were gradual, and similar to the cyclic mobility response in sands.

$>$ Cyclic resistance in normalized stress ratio $\left(N S R=\sigma_{c y c} / S_{u}\right)$ terms fall within a narrow band compared to cyclic resistance expressed in CSR terms.

$>$ Cyclic resistance of Outardes-2 clay is higher than Breckenridge clay. Cyclic resistance of similar clay under triaxial loading mode is significantly higher than that under simple shear

During triaxial cyclic tests, both compression and extension modes are activated during each half of the cycle. There is no unique undrained shear strength $S_{u}$ corresponding to cyclic triaxial tests, which is a clear bias toward the extension direction was present in all cyclic triaxial tests. Therefore, $N S R_{E}$ might be a more appropriate indicator of the cyclic strength of the material, but researchers often use $N S R_{C}$ as the compression strength is the commonly available strength. 


\subsubsection{Dynamic properties of soils}

\subsubsection{Modulus and damping characteristics of sensitive Leda clays}

$>$ The multi stage quasi-cyclic testing method is an effective method to determine the dynamic properties of undisturbed clay samples.

$>$ The general trend of modulus and damping of sensitive Leda clays were captured in the proposed dynamic curves. Additionally, secant shear modulus and normalized shear modulus values decreased with increased shear strain level, while damping ratio increased with shear strain.

$>$ Consolidation pressure significantly influences the secant shear modulus. But it's effect is not significant in normalized shear modulus.

At similar consolidation pressures, secant shear modulus is higher in the specimen with higher OCR values.

$>$ Outardes-2 specimen, which has a lower plasticity index, shows higher secant shear modulus value than Breckenridge specimens.

$>$ The site specific best fit lines for modulus reduction and damping are separately presented for Breckenridge and Outarde-2 clays. Furthermore, those proposed curves indicate that sensitive Leda clays do not continuously follow any specific modulus and damping ratio curves as proposed by Vucetic and Dobry (1991) based on plastic index.

$>$ Triaxial specimens show a very high secant shear modulus than simples shear specimens. 


\subsubsection{Modulus and damping characteristic of sands}

Secant shear modulus of sand increases with increasing consolidation pressure, but this effect is not significant in normalized shear modulus curves.

Relative density $\left(\mathrm{D}_{\mathrm{r}}\right)$ significantly influences the secant shear modulus of sand. The consolidation stress ratio $\left(\mathrm{K}_{\mathrm{c}}\right)$ also affects the secant shear modulus of sand, but additional data is necessary to make firm conclusions.

\subsubsection{Recommendations for future work}

The current research study provides some basic site-specific data about the response of Leda clay samples and dynamic characteristics of relatively clean sands. However, there is a need for additional data in order to enhance the confidence and draw firm conclusions. Some of the key recommendations regarding this research study are listed below.

In this study, monotonic tests were conducted only in the compression loading mode. Shear strength of sensitive Leda clay in extension loading mode is the critical design parameter in some conditions, therefore it as recommended to have monotonic extension strength with compression.

$>$ Normalized stress ratio $\left(N S R=\sigma_{c y c} / S_{u}\right)$ during the cyclic resistance of clay is calculated from compression monotonic shear strength $\left(S_{u}\right)$ in this study. However, it was demonstrated, using data from the literature, that $N S R_{E}$ might be a more appropriate indicator of the cyclic strength of the material.

$>$ The present study is conducted on isotopically consolidated clay specimens $\left(\mathrm{K}_{\mathrm{c}}=\right.$ 1). Further study is needed to understand the effect of consolidation stress ratio on monotonic, cyclic and dynamics properties of sensitive clay. 


\section{Bibliography or References}

Andersen, K. H., Kleven, A., \& Heien, D. (1988). Cyclic soil data for design of gravity structures. Journal of Geotechnical Engineering, 114(5), 517-539.

Anderson, D. G., \& Richart Jr, F. E. (1976). Effects of stratining on shear modulus of clays. Journal of Geotechnical and Geoenvironmental Engineering, 102(ASCE\# 12428).

Ansal, A. M., \& Erken, A. (1989). Undrained behavior of clay under cyclic shear stresses. Journal of Geotechnical Engineering, 115(7), 968-983.

ASTM, D. (n.d.). 4767-95. Standard Test Method for Consolidated Undrained Triaxial Compression Test for Cohesive Soils.

Azzouz, A. S., Malek, A. M., \& Baligh, M. M. (1989). Cyclic behavior of clays in undrained simple shear. Journal of Geotechnical Engineering, 115(5), 637-657.

Been, K., Jefferies, M. G., \& Hachey, J. (1991). Critical state of sands. Geotechnique, 41(3), $365-381$.

Bishop, A. W. (1966). The strength of soils as engineering materials. Geotechnique, 16(2), 91130.

Bishop, A. W., \& Green, G. E. (1965). The influence of end restraint on the compression strength of a cohesionless soil. Geotechnique, 15(3), 243-266.

Bishop, A. W., \& Henkel, D. J. (1962). Measurement of soil properties in the triaxial test.

Blanchette, J.D. (2014). "Interim progress report: Outardes-02 site, Kinburn site and Breckenridge site.” University Laval, Quebec, p 33-79.

Boulanger, R. W., \& Idriss, I. M. (2004). Evaluating the potential for liquefaction or cyclic failure of silts and clays. Davis, California: Center for Geotechnical Modeling.

Boulanger, R. W., \& Idriss, I. M. (2006). Liquefaction susceptibility criteria for silts and clays. 
Journal of Geotechnical and Geoenvironmental Engineering, 132(11), 1413-1426.

Boulanger, R. W., Meyers, M. W., Mejia, L. H., \& Idriss, I. M. (1998 a). Behavior of a finegrained soil during the Loma Prieta earthquake. Canadian Geotechnical Journal, 35(1), $146-158$.

Boulanger, R. W., Meyers, M. W., Mejia, L. H., \& Idriss, I. M. (1998 b). Behavior of a finegrained soil during the Loma Prieta earthquake, (Mlml), 146-158.

Bray, J. D., Durgunoglu, T., Karadayilar, T., Sancio, R. B., Onalp, A., Cetin, O. K., Youd, T . (2004 a). Subsurface Characterization at Ground Failure Sites in Adapazari, Turkey. Journal of Geotechnical and Geoenvironmental Engineering. RESTON: American Society of Civil Engineers. http://doi.org/10.1061/(ASCE)1090-0241(2004)130:7(673).

Bray, J. D., Sancio, R. B., Riemer, M. F., \& Durgunoglu, T. (2004 b). Liquefaction susceptibility of fine-grained soils. In Proc., 11th Int. Conf. on Soil Dynamics and Earthquake Engineering and 3rd Int. Conf. on Earthquake Geotechnical Engineering (Vol. 1, pp. 655662). Stallion Press, Singapore.

Bray, J. D., \& Sancio, R. B. (2006). "Assessment of the liquefaction susceptibility of finegrained soils." Journal of geotechnical and geoenvironmental engineering, 132(9), 11651177.

Casacrande, A., \& Wilson, S. D. (1951). Effect of rate of loading on the strength of clays and shales at constant water content. Geotechnique, 2(3), 251-263.

Castro, G. (1969). Liquefaction of Sands. Harvard University.

Craig, R. F. (2004). Craig's soil mechanics. CRC Press.

Díaz-Rodríguez, J. A., Martínez-Vasquez, J. J., \& Santamarina, J. C. (2009). Strain-rate effects in Mexico City soil. Journal of Geotechnical and Geoenvironmental Engineering, 135(2), 
$300-305$.

Eden, W. J., \& Crawford, C. B. (1957). Geotechnical properties of leda clay in the Ottawa area/Les Proprietes geotechniques de l'argile leda dans la region d'Ottawa

Evans, S. G., \& Brooks, G. R. (1994). An earthflow in sensitive Champlain Sea sediments at Lemieux, Ontario, June 20, 1993, and its impact on the South Nation River. Canadian Geotechnical Journal, 31(3), 384-394.

Fällman, A.-M., Holby, O., \& Lundberg, K. (2001). Kolloiders betydelse för hållfasthet och föroreningstransport i jord. SGI Rapport, (60).

Finn, W. D. L., Ledbetter, R. H., Fleming, R. L. M., Templeton, A. E. M., Forrest, T. W., \& Stacy, S. T. (1991). Dam on liquefiable foundation. In 17th International Cinference on Large Dams (pp. 530-554). Vienna.

Houston, W. N., \& Herrmann, H. G. (1980). “Undrained cyclic strength of marine soils.” Journal of Geotechnical and Geoenvironmental Engineering, 106(ASCE 15503).

Hsu, C.-C., \& Vucetic, M. (2006). Threshold shear strain for cyclic pore-water pressure in cohesive soils. Journal of Geotechnical and Geoenvironmental Engineering, 132(10), $1325-1335$.

Ishihara, K. (1993). Liquefaction and flow failure during earthquakes. Geotechnique, 43(3), 351451.

Ishihara, K. (1996). Soil behaviour in earthquake engineering. Clarendon, Oxford.

Ishihara, K., Tatsuoka, F., \& Yasuda, S. (1975). Undrained deformation and liquefaction of sand under cyclic stresses. Soils and Foundations, 15(1), 29-44.

Ishihara, K., and Takatsu, H., (1979), Effects of over consolidation and Ko conditions on the Liquefaction Characteristics of Sand, Soils and Foundations, 19(4):59-68. 
Jacobsen, L. S. (1930). Steady forced vibrations as influenced by damping. Trans. ASME, 52(15), 169-181.

Jung, Y.-H., Choo, J., Cho, W., \& Chung, C.-K. (2013). Patterns of nonlinear shear stiffness degradation of reconstituted clay with different stress histories. Marine Georesources \& Geotechnology, 31(4), 309-331.

Kim, T. C., \& Novak, M. (1981). Dynamic properties of some cohesive soils of Ontario. Canadian Geotechnical Journal, 18(3), 371-389.

Kramer, S. L. (1996). Geotechnical earthquake engineering. Pearson Education India.

Kuerbis, R. H., \& Vaid, Y. P. (1990). Corrections for membrane strength in the triaxial test.

Ladd, C. C. (1991). Stability evaluation during staged construction. Journal of Geotechnical Engineering, 117(4), 540-615.

Ladd, C. C., \& Foott, R. (1974). New design procedure for stability of soft clays. Journal of the Georechnical Engineering Division, 100(7), 763-786.

Lade, P. (1982). Localization effects in triaxial tests on sand. Proc. IUTAMConf. on Deformation and Failure of Granular Materials, 461-471.

Larew, H. G., \& Leonards, G. A. (1962). A strength criterion for repeated loads. In Highway Research Board Proceedings (Vol. 41).

Lee, K. L. (1979). Cyclic strength of a sensitive clay of eastern Canada. Canadian Geotechnical Journal, 16(1), 163-176.

Lee, K. L., \& Seed, H. B. (1967). Drained strength characteristics of sands. Journal of Soil Mechanics \& Foundations Div, 93(6), 117-141.

Lefebvre, G., LeBoeuf, D., \& Demers, B. (1989). Stability threshold for cyclic loading of saturated clay. Canadian Geotechnical Journal, 26(1), 122-131. 
Logeswaran, P., (2005),Behaviour of Sands under Simultaneous Changes of Volume and Pore Pressure, M.A.Sc. Thesis, Carleton University, Ottawa, Canada, 177p.

Logeswaran, P., (2010), Behaviour of Sands under Generalized Loading and Drainage Conditions, Ph.D. Thesis, Carleton University, Ottawa, Canada, 273p.

Manmatharajan, V., (2011), Initial Stress State and Stress History Effects on Liquefaction Susceptibility of Sands, M.A.Sc. Thesis, Carleton University, Ottawa, Canada, 162p.

Mitchell, R. J., \& King, R. D. (1976). Cyclic loading of an Ottawa area Champlain Sea clay. Canadian Geotechnical Journal, 14(1), 52-63.

Mohanty, W. K., Walling, M. Y., Nath, S. K., \& Pal, I. (2007). First order seismic microzonation of Delhi, India using geographic information system (GIS). Natural Hazards, 40(2), 245260.

Ohara, S., \& Matsuda, H. (1988). Study on the settlement of saturated clay layer induced by cyclic shear. Soils and Foundations, 28(3), 103-113.

Okur, D. V, \& Ansal, A. (2007). Stiffness degradation of natural fine grained soils during cyclic loading. Soil Dynamics and Earthquake Engineering, 27(9), 843-854.

Peck, R. B., \& Terzaghi, K. (1948). Soil mechanics in engineering practice.

Penner, E. (1965). A study of sensitivity in Leda clay. Canadian Journal of Earth Sciences, 2(5), $425-441$.

Quinn, P., D. Hutchinson, D., \& Rowe, R., (2007). Toward a Risk Management Framework: Sensitive Clay Landslide Hazards Affecting Linear Infrastructure in Eastern Canada. $1 s t$ North American Landslide Conference, Vail.

Rankka, K., Andersson-Sköld, Y., Hultén, C., Larsson, R., Leroux, V., \& Dahlin, T. (2004). Quick clay in Sweden. Swedish Geotechnical Institute Report, 65, 145. 
Roscoe, K. H., Schofield, An., \& Wroth, C. P. (1958). On the yielding of soils. Geotechnique, $8(1), 22-53$.

Rosenqvist, I. T. (1953). Considerations on the sensitivity of Norwegian quick-clays. Geotechnique, 3(5), 195-200.

Sancio, R. B., Bray, J. D., Stewart, J. P., Youd, T. L., Durgunoğlu, H. T., Önalp, A., \& Karadayılar, T. (2002). Correlation between ground failure and soil conditions in Adapazari, Turkey. Soil Dynamics and Earthquake Engineering, 22(9), 1093-1102.

Sangrey, D. A., Henkel, D. J., \& Esrig, M. I. (1969). The effective stress response of a saturated clay soil to repeated loading. Canadian Geotechnical Journal, 6(3), 241-252.

Seed, H. B. (1979). Considerations in the earthquake-resistant design of earth and rockfill dams. Geotechnique, 29(3), 215-263.

Seed, H. B., \& Idriss, I. M. (1970). Soil moduli and damping factors for dynamic response analyses.

Seed, H. B., \& Idriss, I. M. (1982). Ground motions and soil liquefaction during earthquakes (Vol. 5). Earthquake Engineering Research Institute.

Seed, H. B., Idriss, I. M., \& Arango, I. (1983). Evaluation of liquefaction potential using field performance data. Journal of Geotechnical Engineering, 109(3), 458-482.

Seed, H. B., \& Peacock, W. H. (1971). Test procedures for measuring soil liquefaction characteristics. Journal of Soil Mechanics \& Foundations Div.

Seed, R. B., Cetin, K. O., Moss, R. E. S., Kammerer, A. M., Wu, J., Pestana, J. M., Kayen, R. E. (2003). Recent advances in soil liquefaction engineering: a unified and consistent framework. In Proceedings of the 26th Annual ASCE Los Angeles Geotechnical Spring Seminar: Long Beach, CA. 
Silvestri, V., Karam, G., Tonthat, A., \& St-Amour, Y. (1989). Direct and Simple Shear Testing of Two Canadian Sensitive Clays. ASTM Geotechnical Testing Journal, 12(1), 11-21.

Sivathayalan, S., \& Ha, D. (2004). Effect of initial stress state on the cyclic simple shear behaviour of sands. In Proceedings of the International Conference on Cyclic Behaviour of Soils and Liquefaction Phenomena, CBSO4, Bochum, Germany (Vol. 31, pp. 207-214).

Sivathayalan, S., \& Ha, D. (2011). Effect of static shear stress on the cyclic resistance of sands in simple shear loading. Canadian Geotechnical Journal, 48(10), 1471-1484.

Sivathayalan, S., \& Vaid, Y. P. (2004). Cyclic resistance and post liquefaction response of undisturbed in-situ sands. In Proceedings of the 13th world conference on earthquake engineering. vancuvor.

Skempton, A. W. (1948). A study of the geotechnical properties of some post-glacial clays. Geotechnique, 1(1), 7-22.

Skempton, A. W. (1954). The pore-pressure coefficients A and B. Geotechnique, 4, 143-147.

Skempton, A. W., \& Northey, R. D. (1952). The sensitivity of clays. Geotechnique, 3(1), 30-53.

Soderblom, R. (1969). Salt in Swedish clays and its importance for quick clay formation.

Sôderblom, R. (1974). Organic matter in Swedish clays and its importance for quick clay formation. In Swedish Geotechnical Institute Proceedings.

Talme, O. A. (1968). Clay sensitivity and chemical stabilization (Vol. 56). Svensk byggtjänst (distr.).

Taylor, D. W. (1943). Cylindrical compression research program on stress-deformation and strength characteristics of soils. 9th Progress Rep. to US Army Corps of Engineers.

Taylor, D. W. (1948). Fundamentals of soil mechanics. New York: John Wiley \& Sons.

Terzaghi, K. (1944). Ends and means in soil mechanics. Harvard University. 
Theenathayarl, T. (2015). Behaviour of sensitive Leda clay under simple shear loading. M.A.Sc. Thesis, Carleton University, Ottawa.

Thiers, G. R., \& Seed, H. B. (1969). Strength and stress-strain characteristics of clays subjected to seismic loading conditions. In Vibration effects of earthquakes on soils and foundations. ASTM International.

Thirugnanasampanther, S. (2016). Cyclic behaviour and dynamic properties of soils under simple shear loading. M.A.Sc. Thesis, Carleton University, Ottawa.

Tuttle, M., Law, K. . ., Seeber, L., \& Jacob, K. (1990). Liquefaction and ground failure induced by the 1988 Saguenay, Quebec, earthquake. Canadian Geotechnical Journal, 27(5), 580589.

Uthayakumar, M., \& Vaid, Y. P. (1998). Static liquefaction of sands under multiaxial loading. Canadian Geotechnical Journal, 35(2), 273-283.

Vaid, Y ., \& Chern, J. . (1985). Cyclic and monotonic undrained response of saturated sands. In In Proceedings of Advances in the Art of Testing Soils under Cyclic Loading Conditions (pp. 120-147). Detroit.

Vaid, Y. P., \& Sivathayalan, S. (1996). Static and cyclic liquefaction potential of Fraser Delta sand in simple shear and triaxial tests. Canadian Geotechnical Journal, 33(2), 281-289.

Vaid, Y. P., \& Sivathayalan, S. (2000). Fundamental factors affecting liquefaction susceptibility of sands. Canadian Geotechnical Journal, 37(3), 592-606.

Vaid, Y. P., Sivathayalan, S., \& Stedman, D. (1999). Influence of specimen-reconstituting method on the undrained response of sand. Geotechnical Testing Journal, 22(3), 187-195.

Vaid, Y. P., \& Thomas, J. (1994). Post-liquefaction behaviour of sand. In Proceedings 13th International Conference on Soil Mechanics and Foundation Engineering (Vol. 3, pp. 
1305-1310). New Delhi: AA BALKEMA.

Vaid, Y. P., \& Thomas, J. (1995). Liquefaction and postliquefaction behavior of sand. Journal of Geotechnical Engineering, 121(2), 163-173.

Vucetic, M. (1994). Cyclic threshold shear strains in soils. Journal of Geotechnical Engineering, 120(12), 2208-2228.

Vucetic, M., \& Dobry, R. (1988). Degradation of marine clays under cyclic loading. Journal of Geotechnical Engineering, 114(2), 133-149.

Vucetic, M., \& Dobry, R. (1991). Effect of soil plasticity on cyclic response. Journal of Geotechnical Engineering, 117(1), 89-107.

Vucetic, M., Lanzo, G., \& Doroudian, M. (1998). Damping at small strains in cyclic simple shear test. Journal of Geotechnical and Geoenvironmental Engineering, 124(7), 585-594.

Wang, W. (1979). Some findings in soil liquefaction. Earthquake Engineering Department, Water Conservancy and Hydroelectric Power Scientific Research Institute.

Wichtmann, T., Andersen, K. H., Sjursen, M. A., \& Berre, T. (2013). Cyclic tests on high-quality undisturbed block samples of soft marine Norwegian clay. Canadian Geotechnical Journal, $50(4), 400-412$.

Woods, R. D. (1994). Laboratory measurement of dynamic soil properties. In Dynamic Geotechnical Testing II. ASTM International.

Yan, L., \& Byrne, P. M. (1990). Simulation of downhole and crosshole seismic tests on sand using the hydraulic gradient similitude method. Canadian Geotechnical Journal, 27(4), $441-460$.

Youd, T. L., Harp, E. L., Keefer, D. K., \& Wilson, R. C. (1985). The Borah peak, Idaho earthquake of October 28, 1983-liquefaction. Earthquake Spectra, 2(1), 71-89. 
Youd, T. L., Idriss, I. M., Andrus, R. D., Arango, I., Castro, G., Christian, J. T., ... Hynes, M. E. (2001). Liquefaction resistance of soils: summary report from the 1996 NCEER and 1998 NCEER/NSF workshops on evaluation of liquefaction resistance of soils. Journal of Geotechnical and Geoenvironmental Engineering, 127(10), 817-833.

Zergoun, M., \& Vaid, Y. P. (1994). Effective stress response of clay to undrained cyclic loading. Canadian Geotechnical Journal, 31(5), 714-727. 